\title{
Development of 1,2,3-triazole-borane complex as effective reagent for aldehyde/ketone reductive amination
}

\author{
Wenyan Liao \\ West Virginia University
}

Follow this and additional works at: https://researchrepository.wvu.edu/etd

\section{Recommended Citation}

Liao, Wenyan, "Development of 1,2,3-triazole-borane complex as effective reagent for aldehyde/ketone reductive amination" (2009). Graduate Theses, Dissertations, and Problem Reports. 2817.

https://researchrepository.wvu.edu/etd/2817

This Thesis is protected by copyright and/or related rights. It has been brought to you by the The Research Repository @ WVU with permission from the rights-holder(s). You are free to use this Thesis in any way that is permitted by the copyright and related rights legislation that applies to your use. For other uses you must obtain permission from the rights-holder(s) directly, unless additional rights are indicated by a Creative Commons license in the record and/ or on the work itself. This Thesis has been accepted for inclusion in WVU Graduate Theses, Dissertations, and Problem Reports collection by an authorized administrator of The Research Repository @ WVU. For more information, please contact researchrepository@mail.wvu.edu. 


\title{
Development of 1,2,3-Triazole-Borane Complex as Effective Reagent for Aldehyde/Ketone Reductive Amination
}

\author{
Wenyan Liao \\ Thesis \\ Submitted to the Eberly College of Arts and Sciences \\ At \\ West Virginia University \\ In partial fulfillment of the requirements for the degree of \\ Master of Science \\ In Organic Chemistry
}

\author{
Xiaodong Michael Shi, Ph.D., Chair \\ George A. O'Doherty, Ph.D. \\ Kung K. Wang, Ph.D. \\ C. Eugene Bennett Department of Chemistry \\ Morgantown, West Virginia \\ 2009
}

Keyword: Lewis Base Catalysis, Isoxazoline-N-oxide, Triazole-Borane, Reductive Amination 


\section{Abstract \\ Synthesis of Isoxazoline- $N$-oxide through [3+2] Cycloaddition Wenyan Liao}

A catalytic cascade synthesis of Isoxazoline $N$-oxide was developed through prolinecatalyzed nitroalkene activation. A large variety of nitroalkenes and vinyl esters were suitable for this transformation, giving only trans isomer with good to excellent yields. Mechanistic studies revealed intramolecular cycloaddition as the rate-determining step. This strategy provided not only a new approach for the construction of substituted isoxazoline derivatives but further evidence of secondary amine nucleophilic activation of nitroalkene, an alternative path of proline catalysis.

\section{Development of 1,2,3-Triazole-Borane Complex as Effective Reagent for Aldehyde/Ketone Reductive Amination Wenyan Liao}

Air, moisture and thermally stable 1,2,3-triazole-boranes were successfully prepared and applied as reductants in aldehyde/ketone reductive amination with high efficiency and excellent substrate diversity. Detailed studies regarding to the reaction mechanism and application of this new reagent for other important transformations are currently under investigation in our group. 


\section{DEDICATED TO}

My parents and my family 


\section{ACKNOWLEDGEMENTS}

I would like to express my sincere gratitude to my advisor, Dr. Xiaodong Michael Shi, for his support, patience, and encouragement throughout my graduate studies. His mentorship was essential to the completion of this thesis and my graduate study.

My thanks also go to Dr. Kung Wang and Dr. George A. O'Doherty for their valuable comments that improved the contents of this thesis and their help during my time at WVU.

I would also like to thank the former and present postdocs, Dr. Haifeng Duan (who helped me a lot during research and provided great contribution in my first project), Dr. Yuxiu Liu and Dr. Yunfeng Chen, my lab mates Cheng Zhong and Sujata Sengupta for their help both in my study and life. I want to thank all the faculty, staff and graduate students in Chemistry Department for their help in a variety of ways.

Most importantly, I would like to thank my father Donghai Liao and my mother Baoyu Yang. Without their love and encouragement, I couldn't even survive in the foreign country. I would like to thank my parents-in-law, Lijuan Sun and Shengfu Zhong as well, who help me take care of my baby and my small family. Thanks to my dear daughter Sophia Zishan Zhong, I finished my own project after having her. Her cries and smiles enrich my life and give me strength to face the difficulties.

The most special thanks will give to my husband Cheng Zhong for his love, understanding and precious help during the past few years. I would never forget the moment when he taught me to draw reaction mechanisms, revised my ppt slides, gave me research suggestions, took care of me when I was sick, and got up in the late night to change baby diapers. His support made this thesis possible. Thank you!

Financial support from the National Science foundation, C. Eugene Bennett Department of Chemistry at West Virginia University are gratefully acknowledged. 


\section{TABLE OF CONTENTS}

Title Page $\quad$ i

Abstract $\quad$ ii

Dedication $\quad$ iii

Acknowledgements $\quad$ iv

Table of Contents $\quad$ V

List of Schemes vii

List of Tables $\quad$ ix

List of Figures $\quad$ ix

List of ${ }^{1} \mathrm{H}$ NMR and ${ }^{13} \mathrm{C}$ NMR Spectra $\quad$ ix

Part I

Synthesis of Isoxazoline- $N$-oxide through [3+2] Cycloaddition

1. Introduction 1

1.1 Cascade reaction in organic synthesis 1

1.2 Lewis base catalysis $\quad 1$

1.3 Literature reported synthesis of isoxazoline $N$-oxide and its applications 3

2. Research objective $\quad 6$

2.1 Lewis-base catalyzed cascade cross conjugated addition 6

2.2 Design of isoxazoline- $N$-oxide Synthesis 6

3. Results and discussion $\quad 6$

3.1 Reaction condition screening $\quad 6$

$\begin{array}{ll}3.2 \text { Substrate scope } & 7\end{array}$

3.3 Deuterium-labeling study 11

3.4 Proposed mechanism 11

3.5 Further functional group transformation 12

4. Conclusions 13 


\section{Part II}

\section{Development of 1,2,3-Triazole-Borane Complex as Effective Reagent for Aldehyde/Ketone Reductive Amination}

1. Introduction 14

1.1 Borane complexes and their reactivity 14

1.2 Reductive amination by different boranes $\quad 20$

1.3 Limitation and challenges of reducing agents 25

2. Research objective 25

$2.11,2,3$-triazole overall view, structures and properties 25

2.1.1 Synthesis of 4,5-disubstituted 1,2,3-( $\mathrm{NH}$ )-triazole 25

2.1.2 Synthesis of metal-triazole Complexes 26

2.2 Design of triazole-borane synthesis 27

3. Results and discussion 28

3.1 Synthesis of triazole-borane complexes 28

3.2 Reductive amination of aldehyde and condition screening 29

3.3 Reductive amination of ketone $\quad 32$

3.4 Reductive amination of unprotected amino acids 33

3.5 Possible future studies $\quad 34$

4. Conclusion $\quad 34$

\section{Part III}

\section{Experimental Section}

General Methods and Materials

Compounds Characterization

References

Appendix $\left({ }^{1} \mathrm{H}\right.$ NMR and ${ }^{13} \mathrm{C}$ NMR Spectra) 


\section{List of Schemes}

Scheme 1A. Enamine Asymmetric Organocatalysis 1

Scheme 1B. Iminium Asymmetric Organocatalysis 2

Scheme 2. Parallels between the Catalyzed (right) and Uncatalyzed (left) Reactions of Unsaturated Functional Groups 2

Scheme 3. Synthesis of Isoxazolidine 3

Scheme 4. Synthesis of Isoxazoline- $N$-oxide by Tartakovskii 3

Scheme 5. Synthesis of Isoxazoline- $N$-oxide by Holy 3

Scheme 6. Synthesis of Isoxazoline- $N$-oxide via O-alkylation 4

Scheme 7. Ring Opening Application 5

Scheme 8. Spiro Mode Intramolecular Cycloadditions 5

Scheme 9. Transformation of Isoxazoline $N$-oxide 5

Scheme 10. Lewis Base Catalyzed Cascade Conjugated Addition 6

Scheme 11. Cycloaddition of Nitroalkene and Vinyl Ether 6

Scheme 12. Deuterium Labeling Study 11

Scheme 13. Proposed Mechanism for the Formation of Isoxazoline $N$-oxide 12

Scheme 14. Explanation of Deuterium Study 12

Scheme 15. Synthetic Application of Isoxazoline $N$-oxide 13

Scheme 16. Typical Borane Complexes 14

Scheme 17. Hydroboration of Alkenes by Borane-THF 14

Scheme 18. Reduction of Amide by Borane-THF 15

Scheme 19. Nitrile Reduction by Borane-Dimethylsulfide 15

Scheme 20. Asymmetric Reduction of Ketones by Chiral CBS and BTHF/BMS 15

Scheme 21. Synthesis of Phosphine-Borane Complexes 16

Scheme 22. Ring Closure Metathesis of Phosphine-Borane Complexes 16

Scheme 23. Synthesis of P-Chirogenic Phosphorus via Phosphine-Borane 16

Scheme 24. First Synthesis of Amine-Borane Complex 16

Scheme 25. Reductive Amination by Triethylamine Borane 17 
Scheme 26. Reductive Ring Closure by tert-Butylamine Borane

Scheme 27. Asymmetric Reduction of Ketones by Diethylaniline Borane 17

Scheme 28. Reduction of Oximes by Pyridine Borane 18

Scheme 29. Reduction of Ketones by PYB and $\mathrm{TiCl}_{4} \quad 18$

Scheme 30. Reductive Amination by 2-Picoline Borane 18

Scheme 31. Synthesis of Zero-Valent Metallaboratranes 19

Scheme 32. Examples of Dihaloboryl, Asymmetic Haloboryl, and Iminoboryl Complexes

Scheme 33. $N$-Heterocyclic Carbene-Borane Complexes $\quad 19$

Scheme 34. Reduction of a Secondary Hexenyl Xanthate with NHC-Borane 20

Scheme 35. Mechanism of Reductive Amination 20

Scheme 36. Synthesis of Pyrrolizidinone Amino Acid via Reductive Amination 21

Scheme 37. Reductive Amination of Sugar and Protein 21

Scheme 38. Reductive Amination by Decaborane 22

Scheme 39. Reductive Amination by Ti(IV) Isopropoxide- $\mathrm{NaBH}_{4}$

Scheme 40. Reductive Amination by $\mathrm{NaBH}(\mathrm{OAc})_{3}$

Scheme 41. Reductive Amination by Dimethylamine Borane 24

Scheme 42. Reductive Amination by Hantzsch Dihydropyridine 24

Scheme 43. Asymmetric Reductive Amination by Hantzsch Dihydropyridine 25

Scheme 44. Preparation of 1,2,3-Triazoles via "Click Chemistry" 25

Scheme 45. One Step Formation of 1,2,3,-(NH)-Triazole 26

Scheme 46. Side Chain Modification of 1,2,3,-(NH)-Triazoles 26

Scheme 47. Preparation of $[\mathrm{Rh}(\mathrm{COD})(\text { Triazole })]_{2}$ Complex 27

Scheme 48. Triazole-Rh(I) Complex Catalyzed Pauson-Khand Reactions 27

Scheme 49. Triazole-Au(I) Catalyzed Intermolecular Hydroamination 27

Scheme 50. Reductive Amination of Ketones 32

Scheme 51. Reductive Amination of Amino Acid 33 


\section{List of Tables}

Table 1. Screening of the Reaction Conditions 7

Table 2. Isoxazoline-N-oxide Synthesis Substrate Scope 8

Table 3. Preparation of Triazole-Borane Complexes 28

Table 4. Condition Screening of Aldehyde Reductive Amination 29

Table 5. Reductive Amination of Aldehydes 30

\section{List of Figures}

Figure 1. Perspective view of the molecular structure of 3k 57

Figure 2. Perspective view of the molecular structure of $\mathbf{3 l}$

Figure 3. Perspective view of the molecular structure of 7a

\section{List of ${ }^{1} \mathrm{H}$ NMR and ${ }^{13} \mathrm{C}$ NMR Spectra}

${ }^{1} \mathrm{H}$ NMR and ${ }^{13} \mathrm{C}$ NMR Spectra of Compound 3a 66-67

${ }^{1} \mathrm{H}$ NMR and ${ }^{13} \mathrm{C}$ NMR Spectra of Compound $3 \mathbf{b}$

${ }^{1} \mathrm{H}$ NMR and ${ }^{13} \mathrm{C}$ NMR Spectra of Compound 3c 70-71

${ }^{1} \mathrm{H}$ NMR and ${ }^{13} \mathrm{C}$ NMR Spectra of Compound 3d

${ }^{1} \mathrm{H}$ NMR and ${ }^{13} \mathrm{C}$ NMR Spectra of Compound 3e 74-75

${ }^{1} \mathrm{H}$ NMR and ${ }^{13} \mathrm{C}$ NMR Spectra of Compound $3 f \quad 76-77$

${ }^{1} \mathrm{H}$ NMR and ${ }^{13} \mathrm{C}$ NMR Spectra of Compound 3g 78-79

${ }^{1} \mathrm{H}$ NMR and ${ }^{13} \mathrm{C}$ NMR Spectra of Compound 3h $\quad 80-81$

${ }^{1} \mathrm{H}$ NMR and ${ }^{13} \mathrm{C}$ NMR Spectra of Compound 3i 82-83

${ }^{1} \mathrm{H}$ NMR and ${ }^{13} \mathrm{C}$ NMR Spectra of Compound 3j 84-85

${ }^{1} \mathrm{H}$ NMR and ${ }^{13} \mathrm{C}$ NMR Spectra of Compound 3k 86-87

${ }^{1} \mathrm{H}$ NMR and ${ }^{13} \mathrm{C}$ NMR Spectra of Compound 31 
${ }^{1} \mathrm{H}$ NMR and ${ }^{13} \mathrm{C}$ NMR Spectra of Compound 3m

${ }^{1} \mathrm{H}$ NMR and ${ }^{13} \mathrm{C}$ NMR Spectra of Compound 3n

${ }^{1} \mathrm{H}$ NMR and ${ }^{13} \mathrm{C}$ NMR Spectra of Compound 30

${ }^{1} \mathrm{H}$ NMR and ${ }^{13} \mathrm{C}$ NMR Spectra of Compound 3p

${ }^{1} \mathrm{H}$ NMR and ${ }^{13} \mathrm{C}$ NMR Spectra of Compound 3q

${ }^{1} \mathrm{H}$ NMR and ${ }^{13} \mathrm{C}$ NMR Spectra of Compound $3 r$ 100-101

${ }^{1} \mathrm{H}$ NMR and ${ }^{13} \mathrm{C}$ NMR Spectra of Compound 5a

101-103

${ }^{1} \mathrm{H}$ NMR and ${ }^{13} \mathrm{C}$ NMR Spectra of Compound $5 \mathbf{b}$ 104-105

${ }^{1} \mathrm{H}$ NMR and ${ }^{13} \mathrm{C}$ NMR Spectra of Compound $5 \mathrm{c}$ 106-107

${ }^{1} \mathrm{H}$ NMR and ${ }^{13} \mathrm{C}$ NMR Spectra of Compound 5d

108-109

${ }^{1} \mathrm{H}$ NMR and ${ }^{13} \mathrm{C}$ NMR Spectra of Compound 7a $110-111$

${ }^{1} \mathrm{H}$ NMR and ${ }^{13} \mathrm{C}$ NMR Spectra of Compound $\mathbf{7 b}$ 112-113

${ }^{1} \mathrm{H}$ NMR and ${ }^{13} \mathrm{C}$ NMR Spectra of Compound 10a 114-115

${ }^{1} \mathrm{H}$ NMR and ${ }^{13} \mathrm{C}$ NMR Spectra of Compound 10b $116-117$

${ }^{1} \mathrm{H}$ NMR and ${ }^{13} \mathrm{C}$ NMR Spectra of Compound 10c 118-119

${ }^{1} \mathrm{H}$ NMR and ${ }^{13} \mathrm{C}$ NMR Spectra of Compound 10d $120-121$

${ }^{1} \mathrm{H}$ NMR and ${ }^{13} \mathrm{C}$ NMR Spectra of Compound 10e $122-123$

${ }^{1} \mathrm{H}$ NMR and ${ }^{13} \mathrm{C}$ NMR Spectra of Compound 10f 124-125

${ }^{1} \mathrm{H}$ NMR and ${ }^{13} \mathrm{C}$ NMR Spectra of Compound $\mathbf{1 0 g}$ 126-127

${ }^{1} \mathrm{H}$ NMR and ${ }^{13} \mathrm{C}$ NMR Spectra of Compound 10h 128-129

${ }^{1} \mathrm{H}$ NMR and ${ }^{13} \mathrm{C}$ NMR Spectra of Compound 10i 130-131

${ }^{1} \mathrm{H}$ NMR and ${ }^{13} \mathrm{C}$ NMR Spectra of Compound 10j 132-133

${ }^{1} \mathrm{H}$ NMR and ${ }^{13} \mathrm{C}$ NMR Spectra of Compound 10k 134-135

${ }^{1} \mathrm{H}$ NMR and ${ }^{13} \mathrm{C}$ NMR Spectra of Compound 101 136-137

${ }^{1} \mathrm{H}$ NMR and ${ }^{13} \mathrm{C}$ NMR Spectra of Compound 10m 138-139 1H NMR and 13C NMR Spectra of Compound 10n $140-141$ 1H NMR and 13C NMR Spectra of Compound 10o $142-143$ 1H NMR and 13C NMR Spectra of Compound 10p 144-145 1H NMR and 13C NMR Spectra of Compound 10q $146-147$ 1H NMR and 13C NMR Spectra of Compound 10r 148-149 1H NMR and 13C NMR Spectra of Compound 12a 
1H NMR and 13C NMR Spectra of Compound 12b

$152-153$

1H NMR and 13C NMR Spectra of Compound 12c

$154-155$

1H NMR and 13C NMR Spectra of Compound 12d

$156-157$

1H NMR and 13C NMR Spectra of Compound 12e

158-159

1H NMR and 13C NMR Spectra of Compound $\mathbf{1 2 f}$

$160-161$

1H NMR and 13C NMR Spectra of Compound 14a

$162-163$

1H NMR and 13C NMR Spectra of Compound 14b

$164-165$

1H NMR and 13C NMR Spectra of Compound 14c

$166-167$

1H NMR and 13C NMR Spectra of Compound 12d

168-169 


\section{Part I \\ Synthesis of Isoxazoline $N$-oxide through [3+2] Cycloaddition}

\section{Introduction}

\subsection{Cascade reaction in organic synthesis}

In modern organic synthesis, efficiency in constructing complex frameworks became more and more important in both academic and industrial research. As one of the most popular techniques to date, multi-component organo catalytic cascade reaction has been widely used to synthesize the backbones of natural compounds due to its high atomic economy and possibility to obtain good stereo selectivity.

\subsection{Lewis base catalysis}

In year 2000, the term "organocatalysis" was brought forward by David Macmillan. Since then, the area became more and more important as an useful methodology. Two main advantages of organocatalysis are: 1 There is no need for metal-based catalysis thus making a contribution to green chemistry. 2 When the organocatalyst is chiral, an avenue is opened to asymmetric catalysis. Common organocatalysts are based on nitrogen such as pyridine used in the Doebner modification of the Aldol condensation, DMAP used in esterifications, DABCO used in the Baylis-Hillman reaction. In the 1970s, a pioneering asymmetric organocatalysed reaction was developed by Hoffmann-La Roche ${ }^{1,2}$, Schering $\mathrm{AG}^{3}$ and Hajos-Parrish. Among the most reported small organic catalysts, proline analogues are popular due to good accessibility and high efficiency. In the reaction, carbonyl group was activated by proline to form corresponding enamin or iminum cation (Scheme 1). Many reactions can be carried out by this strategy, such as Aldol reaction, Mannich reaction, Michael addition, Friedel-Crafts alkylation, epoxidation and DielAlder reaction.

\section{Scheme 1A. Enamine Asymmetric Organocatalysis}

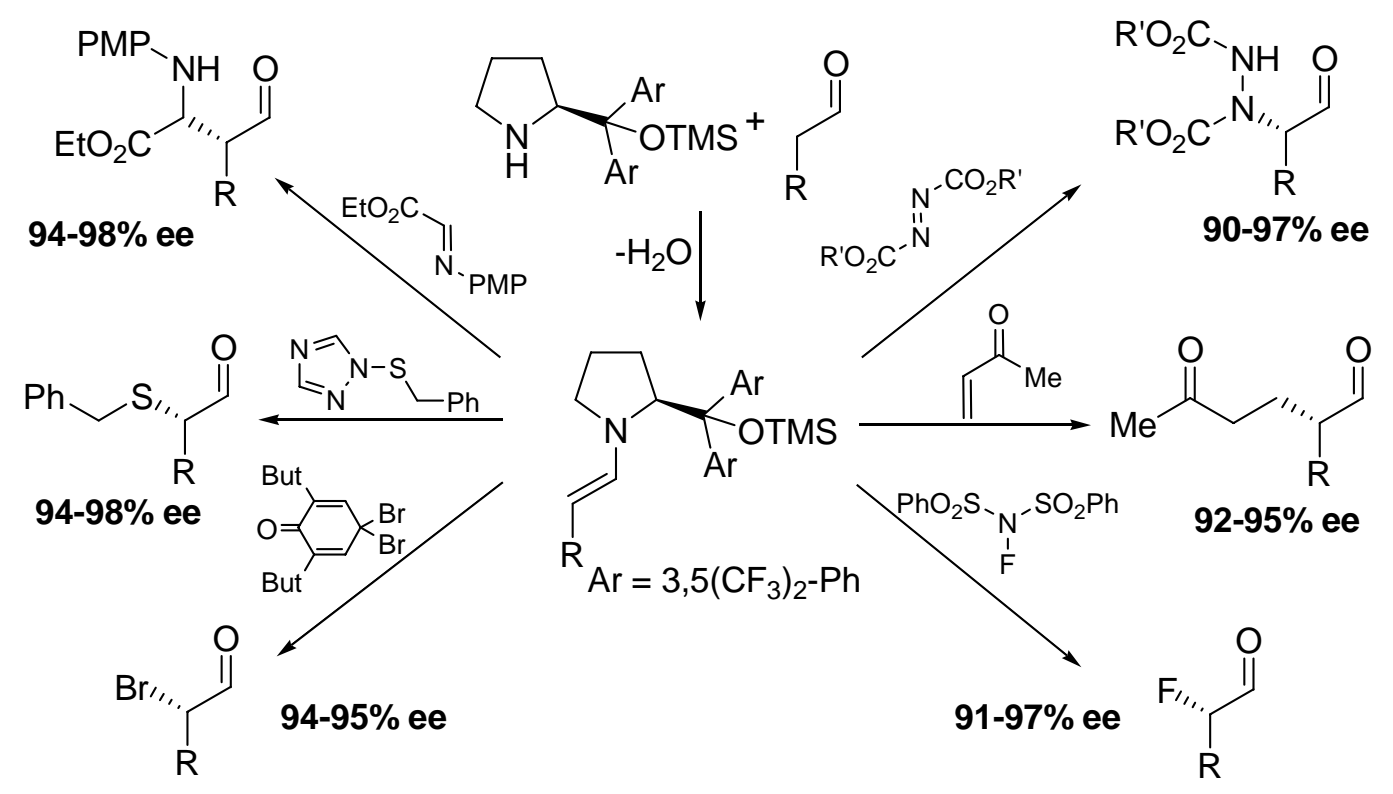




\section{Scheme 1B. Iminium Asymmetic Organocatalysis}

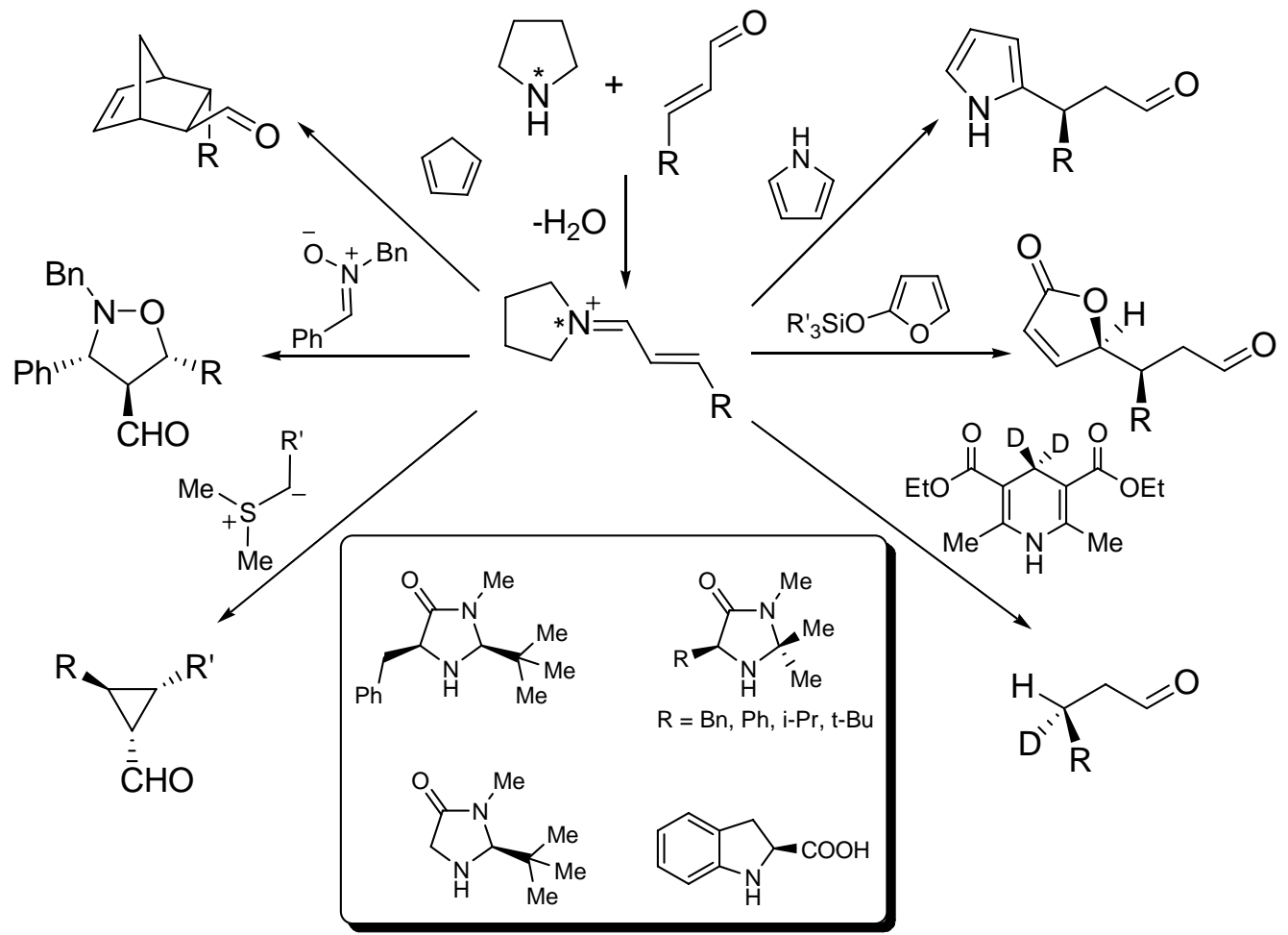

Meanwhile, with the presence of nitrogen lone-pair electrons, amines can also serve as Lewis base catalyst. Lewis base catalysis is the process which an electron-pair donor increases the rate of a given chemical reaction by interacting with an acceptor atom in one of the substrates or the reagents. The binding event may enhance either the electrophilic or nucleophilic character of the bound species so that the reaction can happen (Scheme 2) ${ }^{4}$. Further more, the Lewis base should not be consumed or altered during the course of the reaction. Although Lewis base activation is quite common, it is less widely employed compared to Lewis acids in organic synthesis. Reasons for this include the lack of target Lewis acidic sites as well as the limited number of opportunities for valence expansion at carbon centers.

\section{Scheme 2. Parallels between the Catalyzed (right) and Uncatalyzed Reactions (left) of} Unsaturated Functional Groups

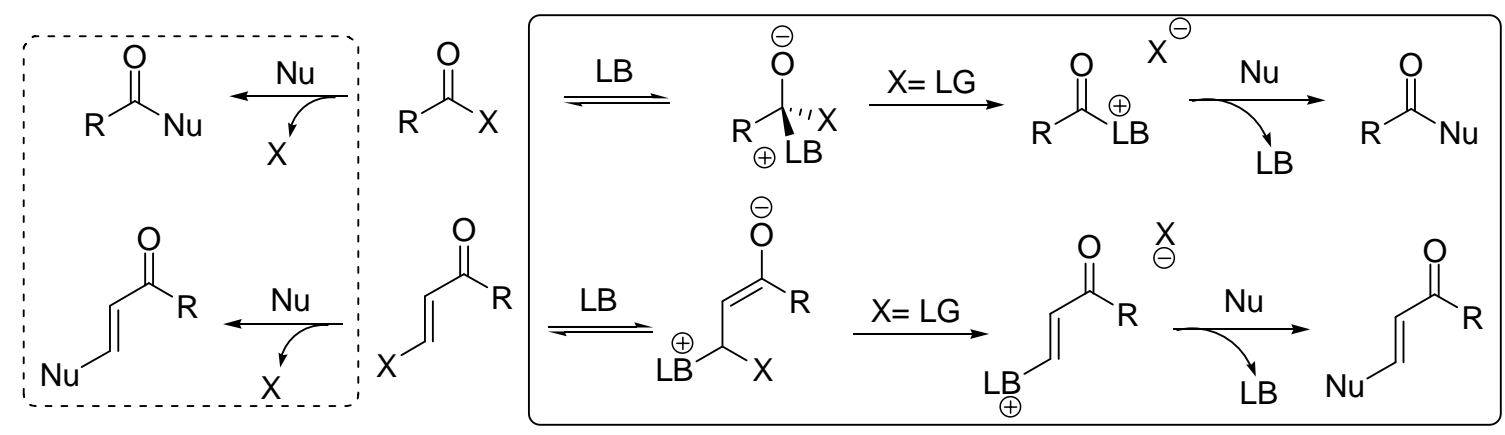




\subsection{Literature reported synthesis of isoxazoline $N$-oxide and its applications}

Isoxazoline $\mathrm{N}$-oxides and their derivatives are frequently used as intermediates in the synthesis of complex molecules in chemical ${ }^{5}$ and biological field ${ }^{6}$. In the year 1964, the fact that nitronic esters undergo 1,3-dipolar cycloaddition to olefins to afford isoxazolidine was discovered and developed by Tartakovskii and co-workers ${ }^{7}$ (Scheme 3 ).

\section{Scheme 3. Synthesis of Isoxazolidine}

$$
\left(\mathrm{NO}_{2}\right)_{2} \mathrm{C}=\mathrm{NO}_{2} \mathrm{CH}_{3}+\mathrm{RHC}=\mathrm{CH}_{2} \longrightarrow \underbrace{\mathrm{NO}_{2}}_{\mathrm{NO}_{2}}
$$

Later on, they developed a strategy by using trinitromethane silver salt react with trimethylsilylchloride to form silylnitronate, followed by [3+2] cycloaddition and elimination to give isoxazoline $\mathrm{N}$-oxide as $\operatorname{product}^{8}$. One synthesis was done recently by using the similar pathway in Tartakovskii's group ${ }^{9}$ (Scheme 4).

\section{Scheme 4. Synthesis of Isoxazoline- $N$-oxide by Tartakovskii}

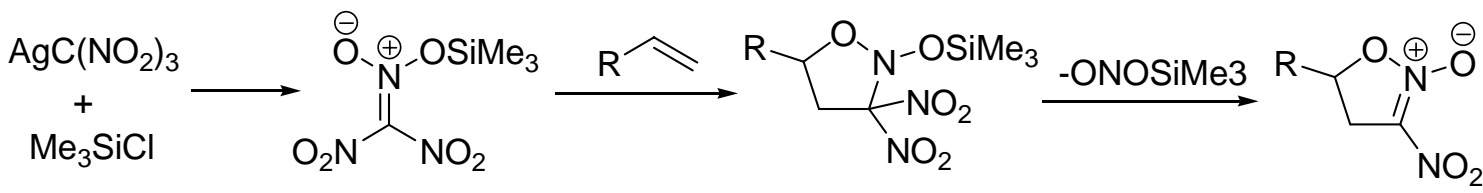

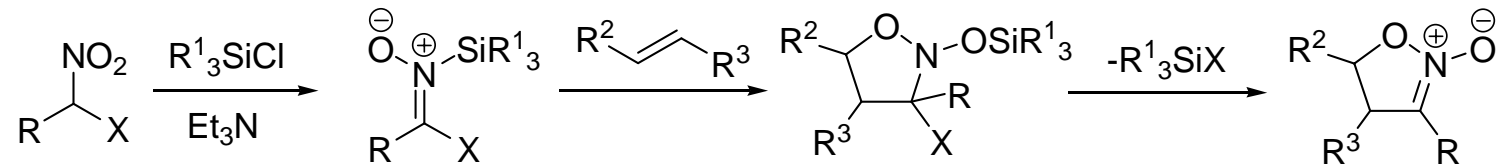

$\mathrm{X}=\mathrm{Br}, \mathrm{F} ; \mathrm{R}=$ alkyl, benyl; $\mathrm{R}^{1}=\mathrm{TBS}, \mathrm{TMS} ; \mathrm{R}^{2}=\mathrm{Ph}, \mathrm{CO}_{2} \mathrm{Me} ; \mathrm{R}^{3}=\mathrm{H}$, Me etc

In 1976, Holy reported that dimethylsulfoxanium methylide could react with nitroalkene to afford isozaxoline $N$-oxides in the presence of copper(I) ${ }^{10}$ (Scheme 5).

Scheme 5. Synthesis of Isoxazoline $N$-oxide by Holy

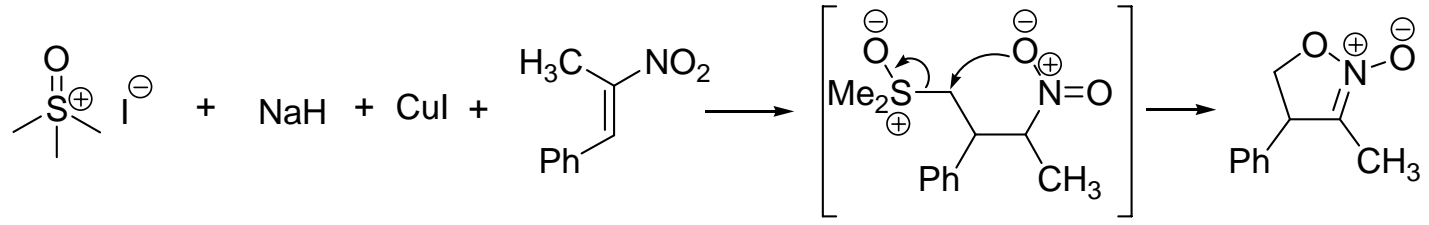

After the pioneer work, different alkyl nitronate was developed for O-alkylation to synthesis isoxazoline $N$-oxide. It is known that reactions at $\mathrm{C}$ atom of nitro compound can happen with different electrophiles, such as aldehydes and epoxides. Thus the incorporation of the nitro moiety and the cycloaddiction can be combined into a tandem sequence. Examples are shown in Scheme 6. 


\section{Scheme 6. Synthesis of Isoxazoline $\boldsymbol{N}$-oxide via $\mathbf{O}$-alkylation}
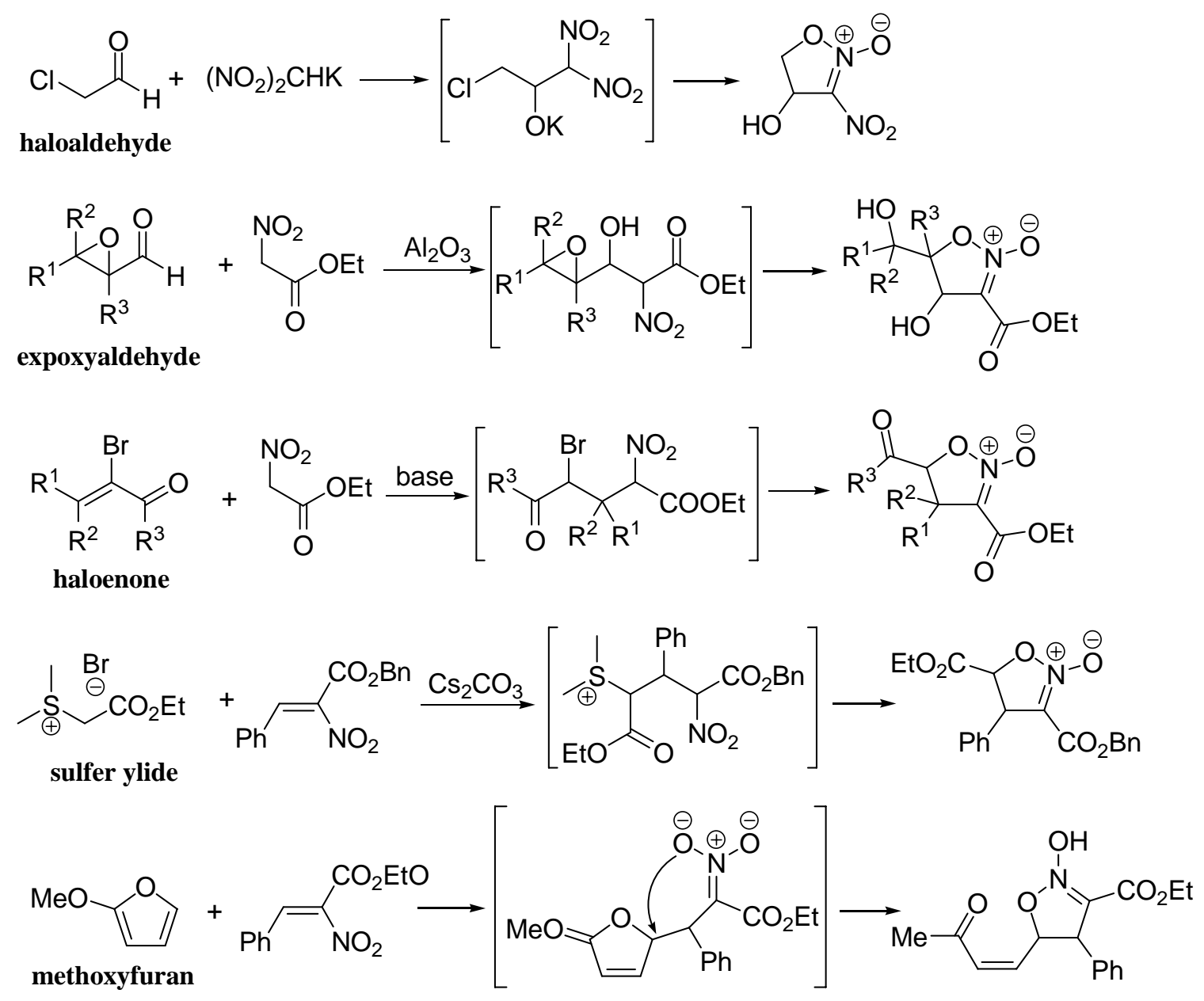

Overall, among the developed protocols, two types of strategies are highly appreciated. One path is the intramolecular O-alkylation of aliphatic nitro compounds. However, no general method for the synthesis of such starting nitro compounds is available, each particular substrate requires special approach. The other way is the highly efficient hetero cycloaddition between nitronates and alkenes (known as [3+2]). Elimination from cyclic nitronic ester to isoxazoline $N$-oxide remains a challenge for this methodology.

The stereoselective synthesis of isoxazoline $N$-oxide is an important task in the context of synthetic strategies toward the preparation of biological target molecules such as polyhydroxylated amino acids, aminopolyols and amino sugars ${ }^{11}$. Within one step reduction, isoxazoline can obtained from isoxazoline $\mathrm{N}$-oxide. $\mathrm{N}-\mathrm{O}$ bond cleavage of isoxazoline followed by hydrolytic workup provides $\beta$-hydroxyketone, hence provides and alternate route to an aldol product. The dehydrogenation of intermediate iminoalcohol arising from $\mathrm{N}-\mathrm{O}$ bond cleavage affords $\beta$-hydroxy nitriles. Complete reduction of the isoxazoline ring delivers $\gamma$-aminoalcohols. Base-mediated ring opening would provide $\alpha, \beta$-unsaturated oximes (Scheme 7). All the hydroxyl compounds can be easily dehydrated or the other functional group can be transformed further to obtain synthetically useful molecules. 


\section{Scheme 7. Ring Opening Application}

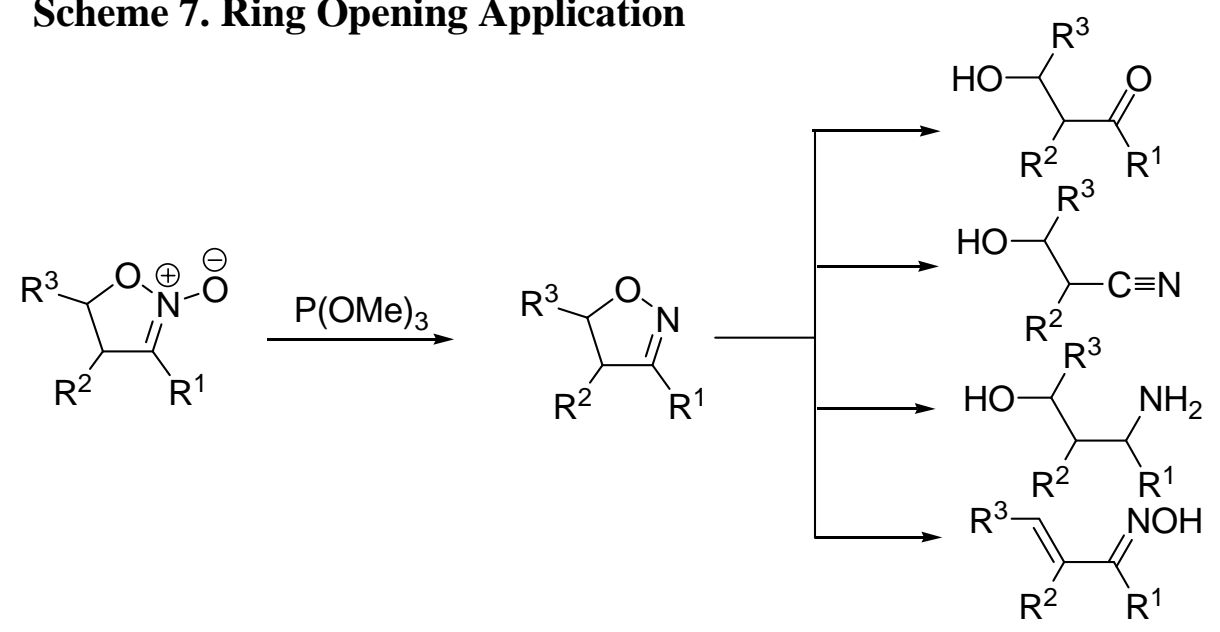

The dipolar character of these cyclic nitronates can be exploited for further 1,3-dipolar cyloaddition with olefins to afford multicyclic structure moiety in total synthesis. The placement of the tether at the $\mathrm{C} 3$ position of the nitronate provides access to the spiro mode cycloadditions. This class has been evaluated for the preparation of five- and sixmembered spiro ring systems ${ }^{12}$ (Scheme 8 ).

\section{Scheme 8. Spiro Mode Intramolecular Cycloadditions}

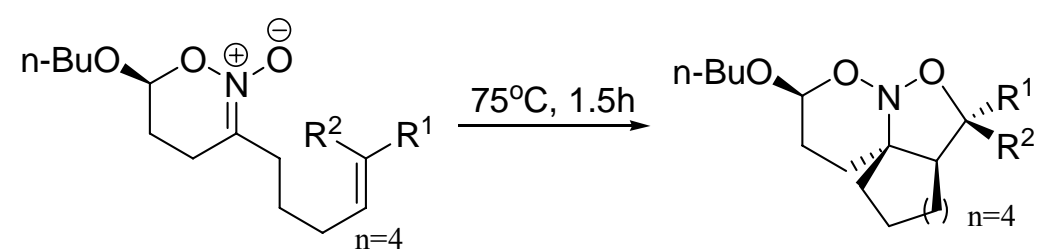

Rosini's group reported the first example of a silicon-tethered intramolecular 1,3dipolar cycloaddition ${ }^{13}$. The tricyclic compound was converted to the corresponding bicyclic diol by an oxidative removal of the temporary silicon linker. The unstable diol was protected immediately as the diacetate. Reductive ring opening of the nitroso acetal moiety was performed with hygrogen and a catalytic amount of Raney $\mathrm{Ni}$, to afford the polyhydroxylated aminolactone derivative (Scheme 9).

\section{Scheme 9. Transformation of Isoxazoline $N$-oxide}

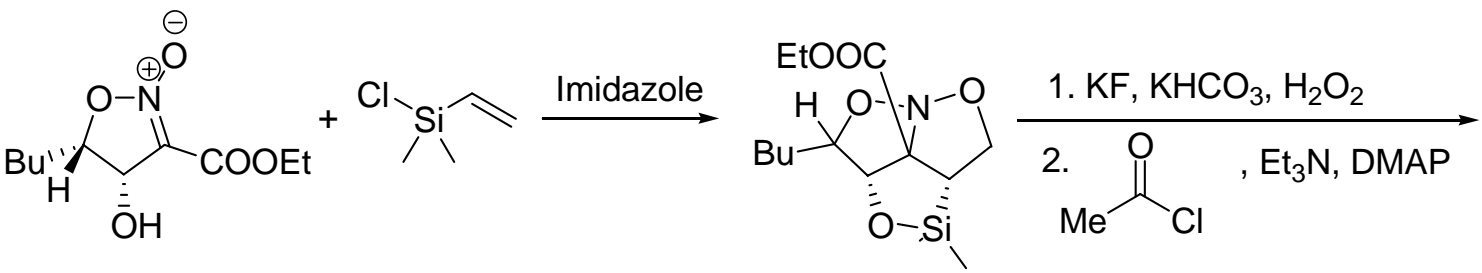

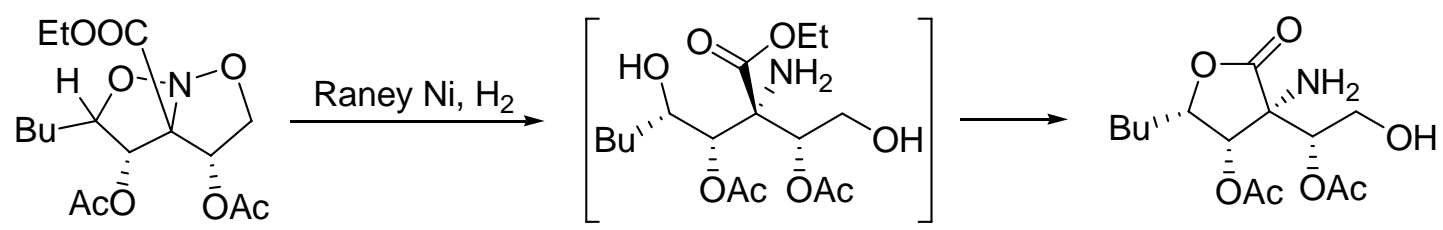




\section{Research Objective}

\subsection{Lewis-base catalyzed cascade cross conjugated addition}

Recently, our group reported a catalytic cascade intermolecular double Michael addition between $\beta$-alkyl nitroalkenes and enones ${ }^{14}$ (Scheme 10). Experimental and computational studies suggested that L-proline served as an effective Lewis base catalyst for activation of nitroalkene to form nitronate as intermediate. This result initiated our interest in other functional group transformation studies based on our proline catalysis system.

\section{Scheme 10. Lewis Base Catalyzed Cascade Conjugated Addition}

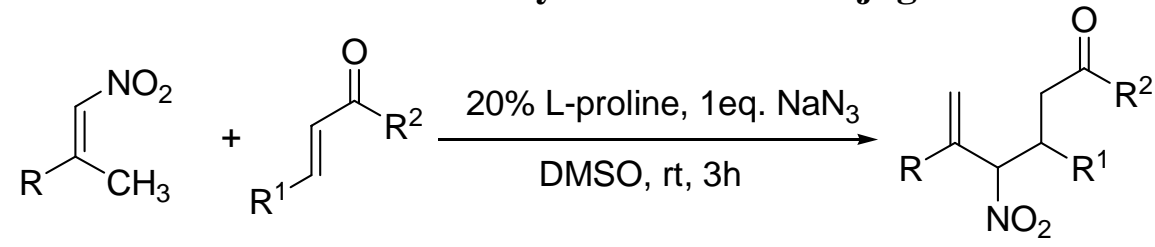<smiles>[R]/C(C)=C/[N+](=O)[O-]</smiles>

\subsection{Design of isoxazoline $\boldsymbol{N}$-oxide synthesis}

The 1,3-dipolarphile can be generated by addition of Lewis base to $\beta$-alkyl nitroalkene. We envisioned that followed by [3+2] cycloaddition with alkene, isoxazoline $N$-oxide will be obtained in high atomic efficiency. To evaluate this design, the one pot cascade reaction of $\beta$-alkyl nitroalkene and vinyl ethyl ether was first applied.

\section{Results and Discussion}

\subsection{Reaction condition screening}

The reaction result of $\beta$-methyl, phenyl nitroalkene 1a and vinyl ethyl ether 2 are shown in Scheme 11.

Scheme 11. Cycloaddition of Nitroalkene and Vinyl Ether

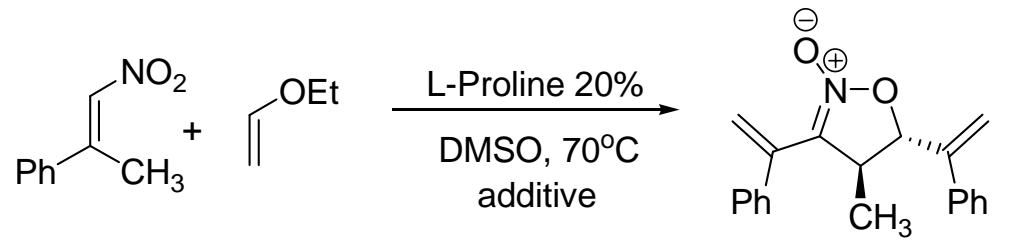

\begin{tabular}{|ccc|}
\hline Entry & Additive & Yield \\
\hline 1 & None & $0 \%$ \\
2 & 1 eq. NaOAc & $5 \%$ \\
3 & 1 eq. BF $_{3}$-THF, 1 eq. NaOAc & $56 \%$ \\
4 & 1 eq. BF $_{3}$-THF & $0 \%$ \\
\hline
\end{tabular}


With only proline as catalyst, no cyclization product was observed, even at $70^{\circ} \mathrm{C}$. The addition of one equivalent $\mathrm{NaOAc}$ help to give isoxazoline $\mathrm{N}$-oxide as single trans isomer product in trace yield. NaOAc might perform as buffer tuning reagent for this transformation. Since OEt group was eliminated during the process, we then test the condition with the presence of one equivalent $\mathrm{BF}_{3}$-THF and $\mathrm{NaOAc}$ along with $20 \%$ of L-proline at $70^{\circ} \mathrm{C}$. Within 10 hours, the yield of isoxazoline $N$-oxide was increased to $56 \%$. Meanwhile with only $\mathrm{BF}_{3}-\mathrm{THF}$ and L-proline, the reaction would not happen. It is expected that the nitronate formed from Lewis base addition to the nitro alkene is crucial for the sequential [3+2] cycloaddition. $\mathrm{BF}_{3}-\mathrm{THF}$ was used as a Lewis acid to bind with oxygen, made OEt a better leaving group for the following elimination.

With the leaving group hypothesis in mind, we then postulated a better leaving group on alkene as acetate. The reaction between nitroalkene 1a and vinyl ether 4a was tested. The results are given in Table 1 .

Table 1. Screening of the Reaction Conditions

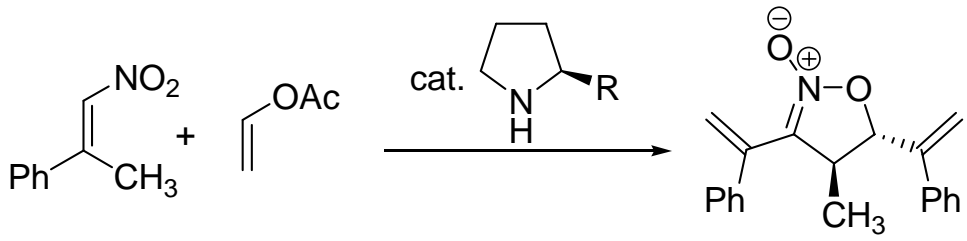

\begin{tabular}{|c|c|c|c|c|c|c|c|}
\hline & & $4 a$ & & & 3 & & \\
\hline Entry & cat. & base & solvent & temp & time(h) & $\operatorname{conv}(\%)$ & yield $(\%)$ \\
\hline 1 & none & none & DMSO & $70^{\circ} \mathrm{C}$ & 8 & 0 & 0 \\
\hline 2 & none & $\mathrm{NaOAc}$ & DMSO & $\mathrm{rt}$ & 8 & 90 & 0 \\
\hline 3 & none & $\mathrm{NaOAc}$ & DMSO & $70^{\circ} \mathrm{C}$ & 8 & 95 & 5 \\
\hline 4 & cat.-1 & none & DMSO & $\mathrm{rt}$ & 24 & 37 & 19 \\
\hline 5 & cat.-1 & $\mathrm{NaOAc}$ & DMSO & $\mathrm{rt}$ & 8 & 99 & 88 \\
\hline 6 & $\mathrm{PPh}_{3}$ & $\mathrm{NaOAc}$ & DMSO & $\mathrm{rt}$ & 8 & 95 & 8 \\
\hline 7 & NMI & $\mathrm{NaOAc}$ & DMSO & $\mathrm{rt}$ & 8 & 87 & 9 \\
\hline 8 & DMAP & $\mathrm{NaOAc}$ & DMSO & $\mathrm{rt}$ & 8 & 85 & 7 \\
\hline 9 & cat.-2 & $\mathrm{NaOAc}$ & DMSO & $\mathrm{rt}$ & 8 & 81 & 20 \\
\hline 10 & cat.-2 & $\begin{array}{l}\mathrm{NaOAc} / \\
\mathrm{HOAc}(20 \%)\end{array}$ & DMSO & $\mathrm{rt}$ & 8 & 88 & 29 \\
\hline 11 & Glycine & $\mathrm{NaOAc}$ & DMSO & $\mathrm{rt}$ & 8 & 90 & 54 \\
\hline 12 & cat.-3 & $\mathrm{NaOAc}$ & DMSO & $\mathrm{rt}$ & 8 & 99 & 45 \\
\hline 13 & cat.-1 & $\mathrm{Cs}_{2} \mathrm{CO}_{3}$ & DMSO & $\mathrm{rt}$ & 8 & 99 & 46 \\
\hline 14 & cat.-1 & $\mathrm{NaOtBu}$ & DMSO & $\mathrm{rt}$ & 8 & 99 & 43 \\
\hline 15 & cat.-1 & $\mathrm{Et}_{3} \mathrm{~N}$ & DMSO & $\mathrm{rt}$ & 10 & 95 & 40 \\
\hline 16 & cat.-1 & $\mathrm{NaOAc}$ & $\mathrm{MeOH}$ & $\mathrm{rt}$ & 8 & 98 & 22 \\
\hline 17 & cat.-1 & $\mathrm{NaOAc}$ & THF & $\mathrm{rt}$ & 24 & 15 & 5 \\
\hline 18 & cat.-1 & $\mathrm{NaOAc}$ & $\mathrm{CH}_{3} \mathrm{CN}$ & $\mathrm{rt}$ & 24 & 10 & trace \\
\hline
\end{tabular}

Reactions were carried out with 1a:4a:cat. $=1: 2: 0.2$. Concentration is $0.2 \mathrm{M}$ of $\mathbf{1 a}$. Conversion was based on the consumption of 1a by NMR. Yield was determined by 
NMR. Cat.-1: $\mathrm{R}=\mathrm{COOH}$; cat-2: $\mathrm{R}=\mathrm{H}$; cat-3: $\mathrm{R}=\mathrm{CH}_{2} \mathrm{NHC}(\mathrm{S}) \mathrm{NHAr}$. $\left(\mathrm{Ar}=2,3-\right.$ di-CF $3^{-}$ $\mathrm{Ph})$.

As shown in Table 1, without L-proline as Lewis base, the thermo [4+2] cycloaddition was not observed even at higher temperature (Entry 1). This is probably due to the steric hindrance of the 2,2-disubstitued nitroalkene 1a. The combination of proline as catalyst and NaOAc as additive was critical for good yield (Entry 2-5). With only NaOAc's presence, significant polymerization of 1a was observed and very small amount of 3a was produced at high temperature (Entry 3). This result suggested that rather than the base deprotonation of the methyl group in nitroalkene, nucleophilic addition by a Lewis base was the key step to form product 3a. Phosphorus nucleophilic catalyst and tertiary amines resulted in significant amount of polymerization. Only secondary and primary amines were found as the effective catalysts for this reaction. Interestingly, glycine gave better yield than pyrrolidine (Entry 9 and 11), even when $20 \%$ of acetic acid was added to mimic the basicity of the proline/NaOAc condition (Entry 10). This effect was further emphasized when thiourea modified proline was applied (Entry 12). Both cases got reasonable good yields. The results strongly imply the formation of an intramolecular Hbond of the amino acid activated nitronate intermediate, which may lead to future enantioselective reactions. Other bases and solvents have also been investigated. NaOAc as an additive in DMSO was identified as the best condition.

\subsection{Substrate scope}

Various nitroalkenes and vinyl esters were applied to investigate the substrate scope. The results are shown in Table 2. 1 (1.0 equiv), 4 (2.0 equiv), L-Proline (20\%), and $\mathrm{NaOAc}$ (1.0 equiv) were dissolved in DMSO (0.2M) and stirred at room temperature for 10 hours. Yields were isolated yields.

\section{Table 2. Isoxazoline- $N$-oxide Synthesis Substrate Scope}

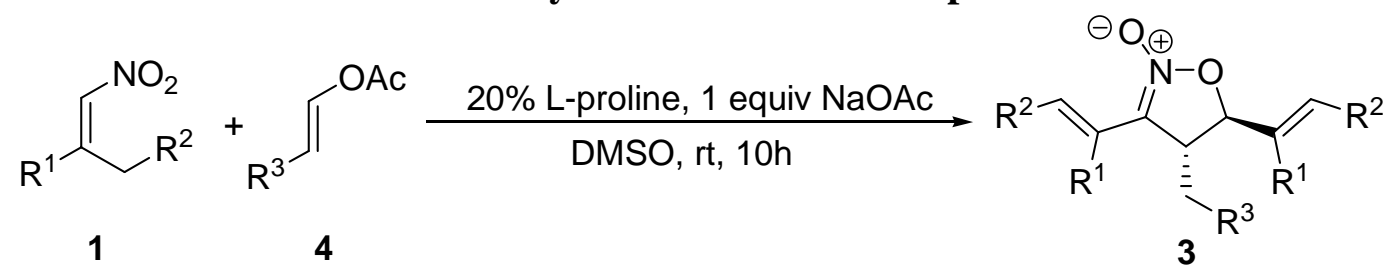

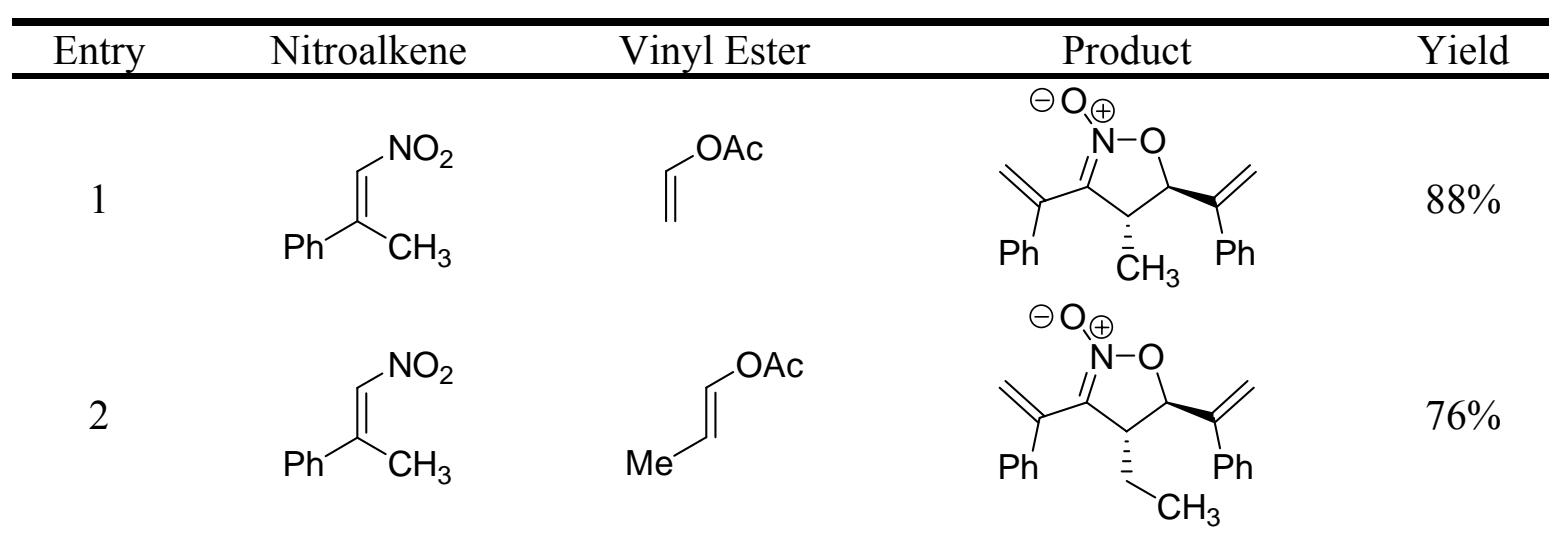


3<smiles>C/C(=C\[N+](=O)[O-])c1ccccc1</smiles>

4<smiles>C/C(=C\[N+](=O)[O-])c1ccccc1</smiles>

5<smiles>CC(=C[N+](=O)[O-])c1ccc(C)cc1</smiles>

6<smiles>CC(=C[N+](=O)[O-])c1ccc(C)cc1</smiles>

7<smiles>C/C(=C\[N+](=O)[O-])c1ccc(Cl)cc1</smiles>

8<smiles>C/C(=C\[N+](=O)[O-])c1ccc(Cl)cc1</smiles>

9<smiles>C/C(=C\[N+](=O)[O-])c1ccc2ccccc2c1</smiles><smiles>C=COC(C)=O</smiles><smiles>CC/C=C/OC(C)=O</smiles><smiles>CC(=O)O/C=C/Cc1ccccc1</smiles><smiles>C=COC(C)=O</smiles><smiles>CC(=O)O/C=C\Cc1ccccc1</smiles><smiles>CC=COC(C)=O</smiles><smiles>C=COC(C)=O</smiles><smiles>C=C(C(=C)C1ON([O-])C(C(=C)c2ccccc2)C1CC)c1ccccc1</smiles><smiles>C=C(C1=[N+]([O-])OC(C(=C)c2ccccc2)[C@H]1CCc1ccccc1)c1ccccc1</smiles>
$65 \%$ $83 \%$ $66 \%$ $77 \%$ $58 \%$ $75 \%$ 
10<smiles>C/C(=C\[N+](=O)[O-])c1ccc2ccccc2c1</smiles>

11<smiles>CC/C(=C\[N+](=O)[O-])c1ccccc1</smiles>

12<smiles>O=[N+]([O-])C=C1CCCCC1</smiles>

13<smiles>O=[N+]([O-])C=C1CCCCC1</smiles>

14<smiles>O=[N+]([O-])C=C1CCCCC1</smiles>

15<smiles>O=[N+]([O-])C=C1CCCCC1</smiles>

16<smiles>O=[N+]([O-])C=C1CCCC1</smiles>

17<smiles>O=[N+]([O-])C=C1CCCC1</smiles>

18<smiles>CC(=O)O/C=C/Cc1ccccc1</smiles><smiles>C=COC(C)=O</smiles><smiles>C=COC(C)=O</smiles><smiles>CC=COC(C)=O</smiles><smiles>CC/C=C/OC(C)=O</smiles><smiles>CC(=O)O/C=C/Cc1ccccc1</smiles><smiles>C=COC(C)=O</smiles><smiles>CC=COC(C)=O</smiles><smiles>C=COC(C)=O</smiles>

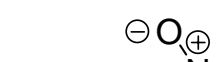<smiles>C=C(C1=NOC(C(=C)c2ccc3ccccc3c2)[C@@H]1CCPc1cccc2ccccc12)c1ccc2ccccc2c1</smiles>

$61 \%$<smiles>[Os]</smiles><smiles>C/C=C(\C1=NOC(/C(=C/C)c2ccccc2)[C@H]1C)c1ccccc1</smiles>

$87 \%$<smiles>C[C@H]1C(C2=CCCCC2)=NO[C@@H]1C1=CCCCC1</smiles><smiles>[Os+2]</smiles><smiles>CC[C@@H]1C(C2=CCCCC2)=NO[C@H]1C1=CCCCC1</smiles><smiles>[Y60][CH][C@H]1C(C2=CCCCC2)=[N+]([O-])O[C@H]1C1=CCCCC1</smiles><smiles>[Os]</smiles><smiles>C1=C(C2=NOC(C3=CCCCC3)[C@@H]2CCc2ccccc2)CCCC1</smiles>

$72 \%$

$65 \%$

$55 \%$ 
The substrates include aryl-alkyl and dialkyl (both cyclic and acyclic) nitroalkenes. A severe polymerization was observed when using monoalkyl or monoaryl nitroalkenes as the starting material, giving only trace amount of desired isoxazoline product. Different $\beta$-substituted vinyl esters were also tested for this transformation, giving easy access to the C-4 position of product. Notably, all cases give trans diastereomer as the only product.

\subsection{Deuterium-labeling study}

To further elucidate the reaction mechanism, especially the stereoselectivity, deuterium exchange study have been performed. When recharging product 3a into the reaction condition under the presence of $\mathrm{D}_{2} \mathrm{O}$, no deuterium exchange was observed from NMR, which implied that no epimerization of the C-5 stereogenic center occurred after 3a was formed. Therefore, the cyclization should be the key step that account for the formation of the single trans isomer. A reaction between 1a and 2a was then performed in the presence of $\mathrm{D}_{2} \mathrm{O}$. As expected, deuterium exchange was observed on the C-5 position along with the C-4 methyl groups and two alkene groups (Scheme 12). Notably, no deuterium exchange was obtained on the C-4 hydrogen. Therefore, a mechanism is proposed.

\section{Scheme 12. Deuterium Labeling Study}<smiles>C=C(C1=[N+]([O-])OC(C(=C)c2ccccc2)C1C)c1ccccc1</smiles>

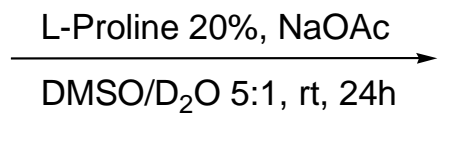

no deuterium exchange observed<smiles>C=COC(C)=O</smiles><smiles>COO[C@H](OC)OC(=O)O[Na]</smiles>

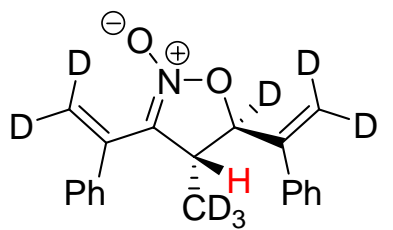

\subsection{Proposed mechanism}

As illustrated in Scheme 13, the reaction between 1a and proline produced nitro carbanion intermediate $\mathbf{B}$. It is likely that $\mathbf{B}$ underwent a [3+2] dipolar cycloaddition with vinyl ester, forming five-membered heterocyclic intermediate C. However, the transformation from $\mathbf{B}$ and vinyl ester to $\mathbf{F}$ can went through different mechanisms, where the cycloaddition and retro-electro cycloaddition is just one possible pathway. And the formation of diene $\mathbf{F}$ is confirmed during our further study. The second nucleophilic addition of nitronate $\mathbf{B}$ to diene $\mathbf{F}$ underwent a Mukaiyama-type transition state, gave the corresponding intermediate G. After the fast epimerization of the C-5 proton, the cyclization of $\mathbf{H}$ gave the trans isomer as the only product. The fact that no proton exchange occurred on the $\mathrm{C}-4$ position was consistent with the proposed mechanism. 


\section{Scheme 13. Proposed Mechanism for the Formation of Isoxazoline- $N$-oxide}<smiles>CC(C)NCCC(=C[N+](=O)[O-])c1ccccc1</smiles>

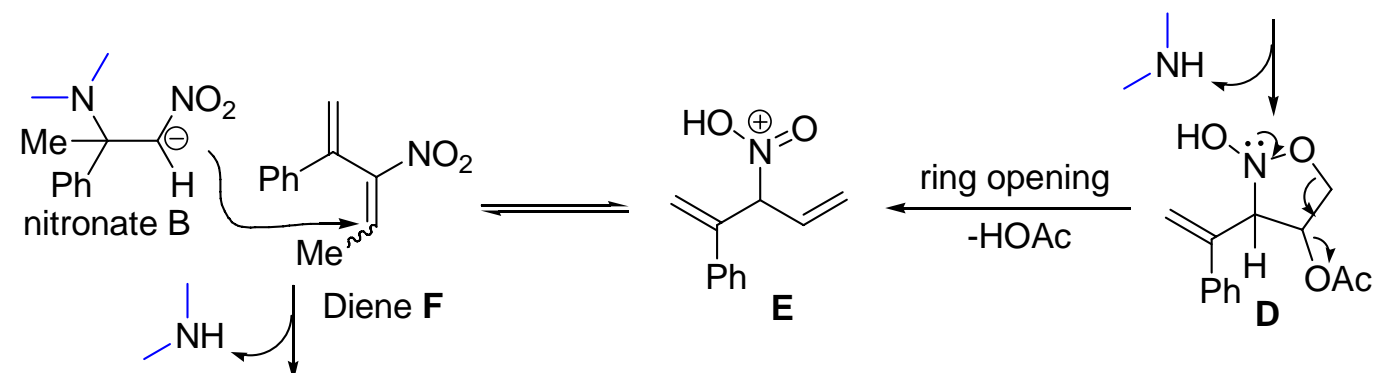

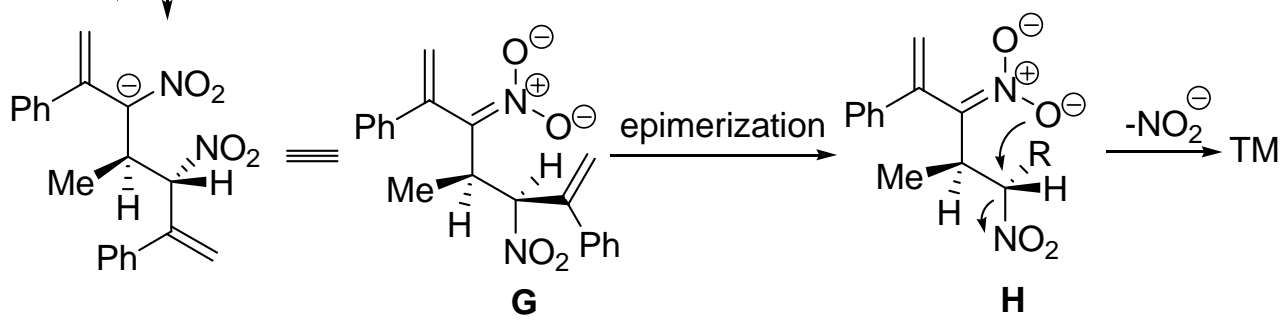

If the reaction is carried out under deuterium environment, D-H exchange could happen in each equilibrium, such as in the intermediate $\mathbf{B}$ and F. However the C-4 H derived from starting material vinyl ester will stay the same, since it was not deprotonated during the whole process.

\section{Scheme 14. Explaination of Deuterium Study}
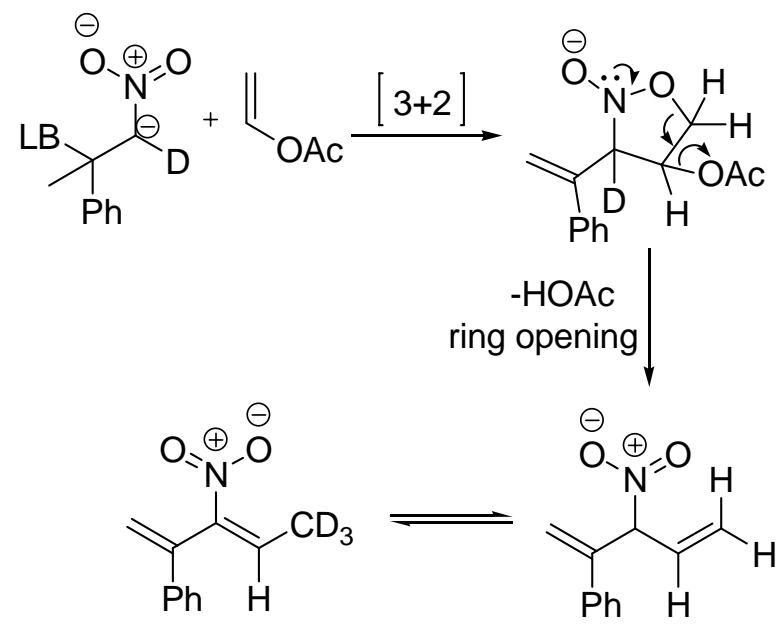

\subsection{Further functional group transformation}

As a very useful synthon, the isoxazoline $N$-oxide can be readily converted into other synthetically attractive building blocks. It can be oxidized to isoxazolidine or reduced to $\beta$-hydroxy amine through easy steps as shown in scheme 15 . 


\section{Scheme 15. Synthetic Application of Isoxazoline- $\mathrm{N}$-oxide}
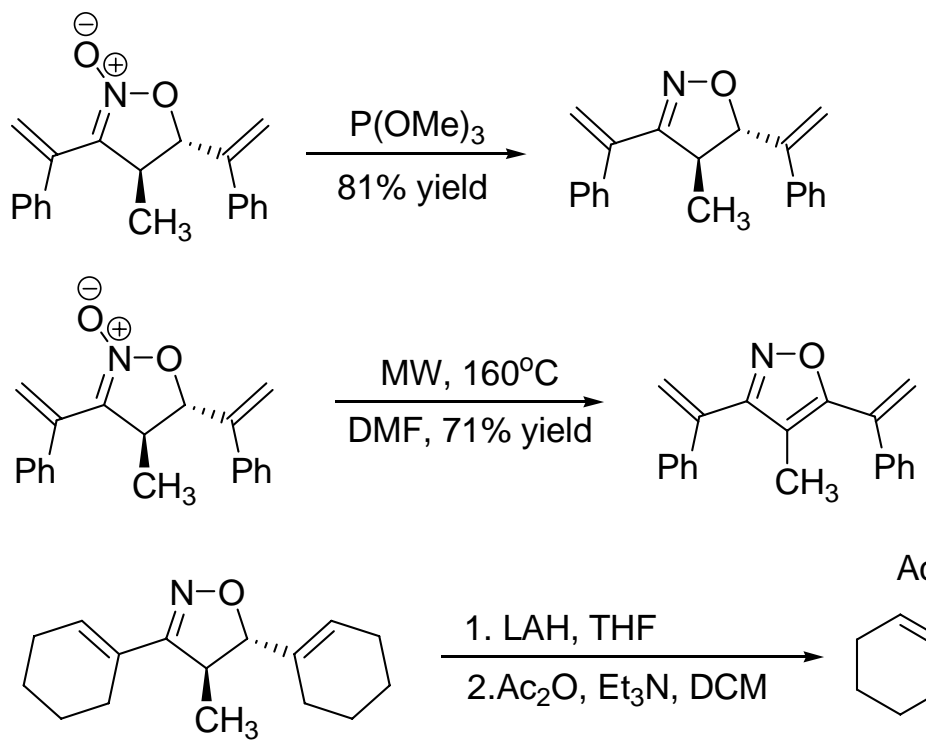

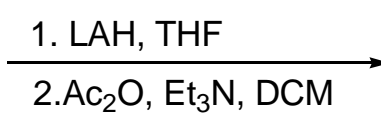

\section{Conclusions}

In conclusion, a catalytic cascade one-step synthesis of isoxazoline $\mathrm{N}$-oxide was developed. A large variety of nitroalkenes and vinyl esters were suitable for this transformation, giving only trans isomer with good to excellent yields. Mechanistic studies revealed intramolecular nitronate cycloaddition as the rate-determining step. This strategy provided not only a new approach for the construction of substituted isoxazoline derivatives but also further evidence of secondary amine nucleophilic activation of nitroalkene, an alternative path of proline catalysis. Other secondary/primary aminepromoted nitroalkene cascade reactions are currently under investigation in our group. 


\section{Part II}

\section{Development of 1,2,3-Triazole-Borane Complex as Effective Reagent for Aldehyde/Ketone Reductive Amination}

\section{Introduction}

\subsection{Borane complexes and their reactivity}

The application of boron reagents in organic synthesis led to Herbert C. Brown being awarded the Nobel Prized in Chemistry in $1979^{15}$. Since then, this relatively rare element has remained on the cutting-edge of modern synthetic chemistry.

Borane is well known for the hydroboration of alkenes and alkynes. It's an avid electron-pair acceptor, having only six valence electrons on boron. Borane complexes can be described as Lewis acid-base adducts of acidic $\mathrm{BH}_{3}$ with different bases, include ethers, sulfides, phosphines and amines (Scheme 16).

\section{Scheme 16. Typical Borane Complexes}

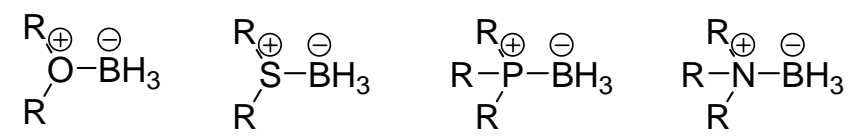

Borane-tetrahydrofuran (BTHF) and borane-dimethyl sulfide(BMS) are often used as a borane source. Both reagents are in solution, and are therefore easier to handle than gaseous diborane. BTHF and BMS are widely used in hydroboration. They also offer interesting applications in the reduction of various functional groups, such as the direct reduction of amides to amines (BTHF) and carboxylic acids to alcohols (BMS). An example of BTHF is in the hydroboration of an alkene followed by oxidation, regioselectively gave the desired anti-Markovnikov alcohol ${ }^{16}$ (Scheme 17).

Scheme 17. Hydroboration of Alkenes by Borane-THF

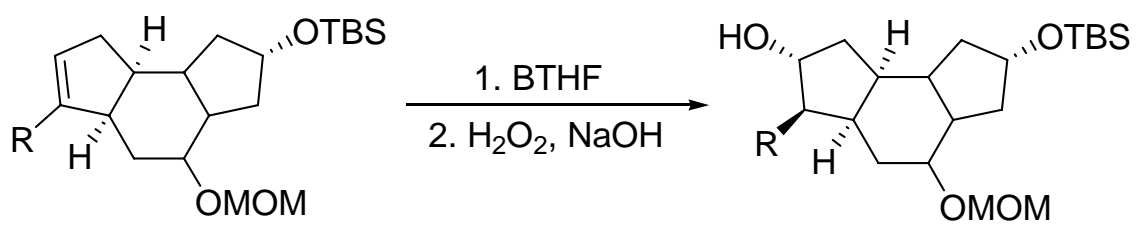

EPIX Medical has used BTHF for the reduction of an amide in the synthesis of an injectable vascular contrast agent. They optimized conditions to minimize reduction of the Boc protecting group ${ }^{17}$ (Scheme 18).

Scheme 18. Reduction of Amide by Borane-THF<smiles>CC(C)(C)OC(=O)NC(CO)CNCCNC(=O)C(CO)NC(=O)OCc1ccccc1</smiles> 
Compare with BTHF, the distinct advantage of borane-dimethylsulfide is its stability, allowing the production of BMS in high concentrations( $\sim 10 \mathrm{M})$. Oxidation after the reaction effectively removes the dimethylsulfide component. A nitrile reduction ${ }^{18}$ is shown in Scheme 19.

\section{Scheme 19. Nitrile Reduction by Borane-Dimethylsulfide}

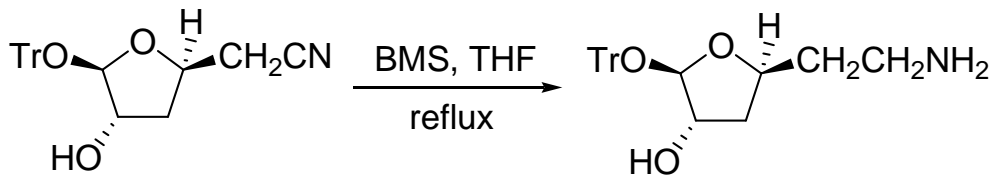

Tr: triphenylmethyl

Further applications were developed in the recent years: In 2008, Attlesey in BASF synthesized a new kind of borane complexes with substituted THF ethers and applied them as reagents for asymmetric reduction of acetophenone ${ }^{19}$. In 2004, Santhosh's group developed recyclable fluorous borane-sulfide compounds to overcome the extremely volatile and environmentally unacceptable $\mathrm{Me}_{2} \mathrm{~S}$ associate with $\mathrm{BMS}^{20}$. In addition to their usefulness as a regio- and chemoselective reducing agent, BTHF and BMS are often used with chiral oxazaborolidine catalysts for asymmetric ketone reduction. The most famous example is CBS catalyst ${ }^{21,22}$ (Scheme 20 ).

\section{Scheme 20. Asymmetric Reduction of Ketones by Chiral CBS and BTHF/BMS}

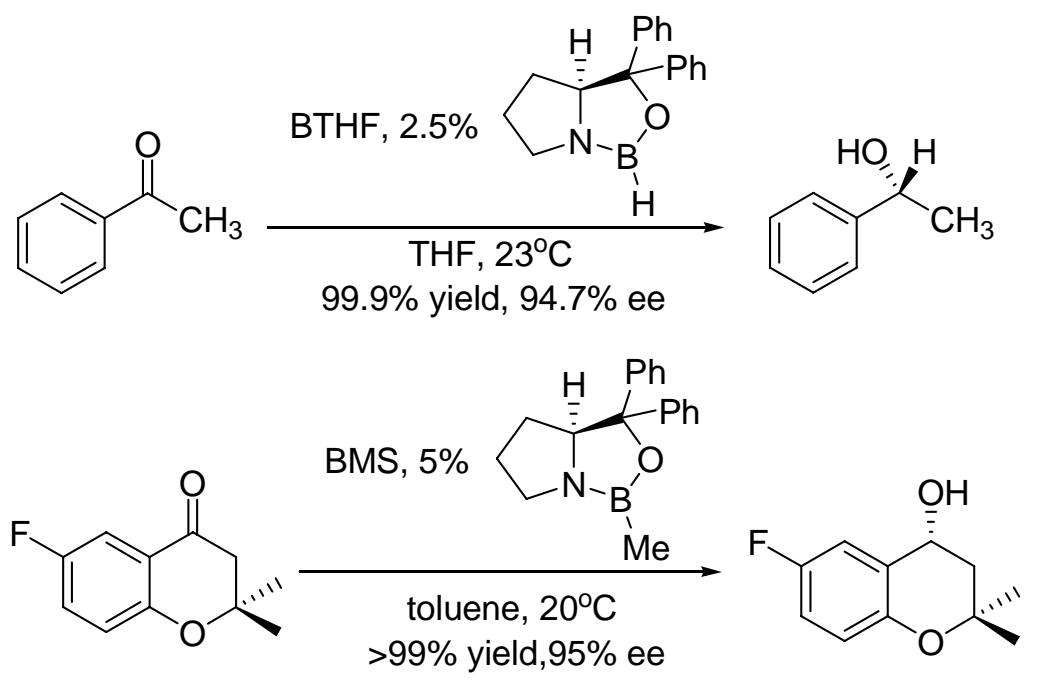

Phosphine-borane complexes were first reported by Burg and Wagner ${ }^{23}$ in 1953. In 2004, Zhou and Manulty reported a simple, general, economical synthesis of phosphineborane complexes using sodium borohydride as the borane source ${ }^{24}$ (Scheme 21). These phosphine-borane complexes can be used in the synthesis of soluble hindered phosphine ligands and polymer-linked hindered phosphines. 


$$
\begin{aligned}
& \text { Scheme 21. Synthesis of Phophine-Borane Complexes }
\end{aligned}
$$

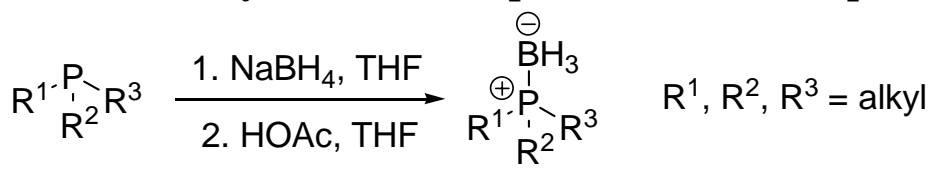

Posphine-borane can also be used in the synthesis of biologically active phosphorus heterocycles using a ring closure enyne metathesis methodology ${ }^{25}$ (Scheme 22).

\section{Scheme 22. Ring Closure Metathesis of Phosphine-Borane Complexes}

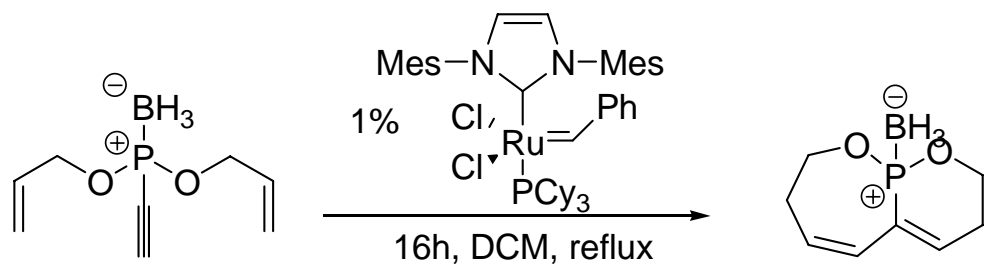

Another application of phosphine-borane is the synthesis of P-chirogenic phosphines ${ }^{26}$. The oxazaphospholidine boranes were prepared by heating bis(dimethylamino)phosphine in toluene with ephedrine followed by addition of BMS(or BTHF). A regioand stereoselective ring-opening of the heterocycle leading to an aninophosphine borane. Finally, the complex was easily transformed into the desired product by subsequent highly stereoselective reactions involving electrophilic or nucleophilic strategies (Scheme 23).

Scheme 23. Synthesis of P-Chirogenic Phosphorus via Phosphine-Borane

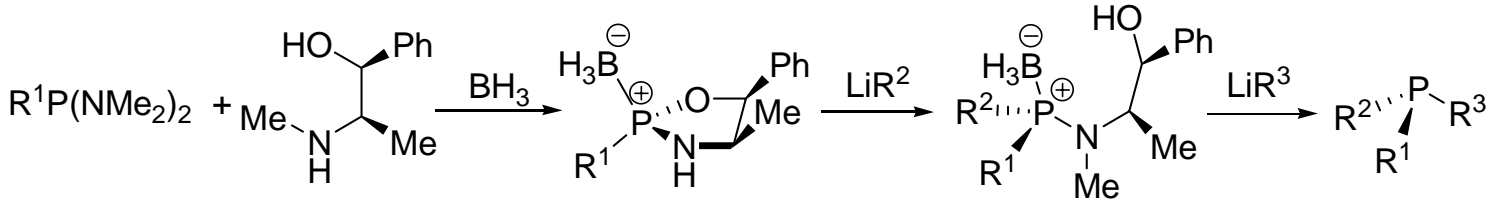

The first amine-borane complex (Scheme 24) was reported in 1937 and was prepared by the direct reaction of diborane with trimethylamine ${ }^{27}$. Since then different types of amines have been used to prepare amine-boranes.

\section{Scheme 24. First Synthesis of Amine-Borane Complex}

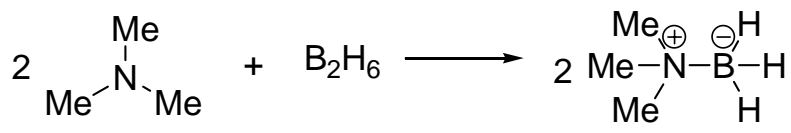

Triethylamine borane can be used in the reduction of carboxylic acid, ketone and aldehyde groups at $80^{\circ} \mathrm{C}$ without solvent. In addition, triethylamine-borane has been effectively used in the reductive amination ${ }^{28}$ (Scheme 25). 


\section{Scheme 25. Reductive Amination by Triethylamine Borane}

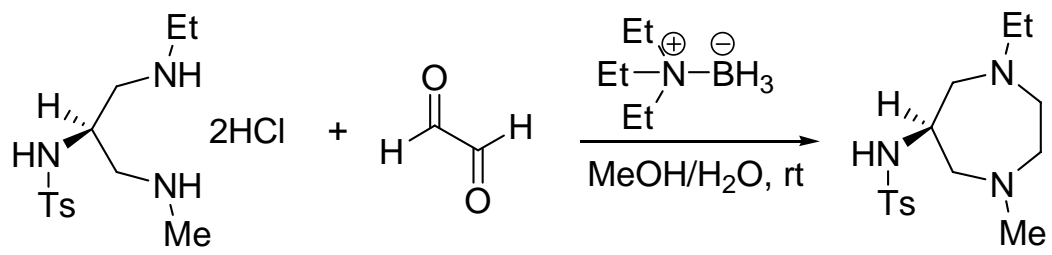

Aldyhydes can be selectively reduced in the presence of ketones by using tertbutylamine borane as the reducing agent. Tert-butylamine borane is also effective for reductive aminations, and for the reduction of enones at room temperature to give allylic alcohols. The following reaction shows tert-butylamine borane in a reductive ring closure for the synthesis of a benzazepine drug intermediate ${ }^{29}$.

\section{Scheme 26. Reductive Ring Closure by tert-Butylamine Borane}

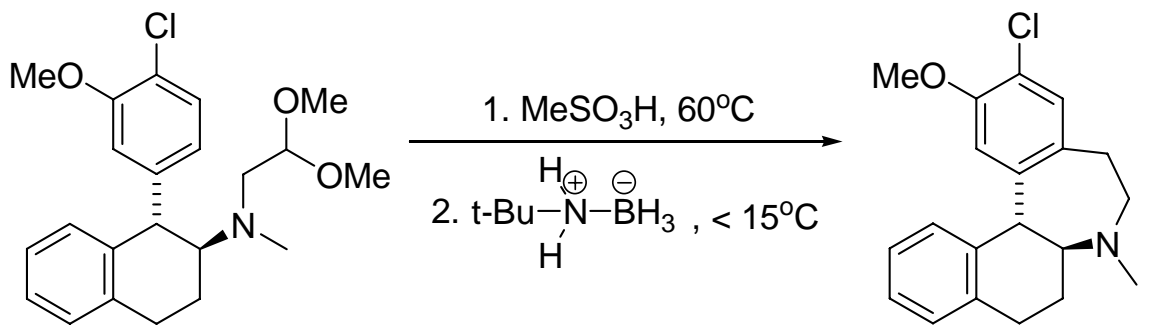

$\mathrm{N}, \mathrm{N}$-diethylaniline borane is a moderately reactive amine borane as a neat liquid. It is moisture sensitive and must be used in aprotic solvents. When combined with CBS catalyst, N-N-diethylaminlin is an excellent borane source for the enantioselective reduction of ketones ${ }^{30}$. For example, in the scale-up of a key intermediate of formoterol, a bronchiodilator, N,N-diethylaniline borane was used as the borane source in the enantioselective ketone reduction ${ }^{31}$ (Scheme 27).

\section{Scheme 27. Asymmetric Reduction of Ketones by Diethyaniline Borane}<smiles>O=C(CBr)c1ccc(OCc2ccccc2)c([N+](=O)[O-])c1</smiles><smiles>[B]N(CC)c1ccccc1CC(F)(F)F</smiles><smiles>O=[N+]([O-])c1cc([C@@H](O)CBr)ccc1OCc1ccccc1</smiles>

Pyridine borane (PYB) can be used to reduce oximes to the corresponding hydroxyl amines $^{32}$ (Scheme 28). Reductions of oximes take places in the presence of other functional groups such as esters, nitriles, amides, and alkyl halides. Pyridine borane can also be used for reductive aminations. 


\section{Scheme 28. Reduction of Oximes by Pyridine Borane}<smiles>[R]CC1CC1CN(CC1CC1C[R])OC(=O)OC</smiles>

Reduction of $\beta$-keto sulfones with pyridine borane in the presence of $\mathrm{TiCl}_{4}$ resulted in ketone reduction primarily via a titanium chelated intermediate yielding erythro- $\beta$ hydroxy sulfones ${ }^{33}$.

Scheme 29. Reduction of Ketones by PYB and $\mathrm{TiCl}_{4}$<smiles>CC(=O)C(c1ccccc1)S(=O)(=O)c1ccccc1</smiles>

$95 \quad: \quad 5$

2-picoline borane is a valuable reagent for reductive aminations. The imine group is reduced by 2-picoline borane to an amine, while leaving cyano and chloro functionalities unaffected. Aromatic ketones can be aminated quite easily with 2-picoline borane $^{34}$ (Scheme 30$)$. The reduction proceeds rapidly when conducted in methanol, water or even without solvent to give secondary amines in excellent yields.

Scheme 30. Reductive Amination by 2-Picoline Borane<smiles>COC(=O)CC1(C(=O)OC)CCCCC1</smiles>

Besides synthetic applications, amine-borane complexes are widely used in industry. For example, amine-boranes can perform as stabilizers and purifiers, fuel additives, photographic reagents, polymerization catalysts, and chemical plating agents ${ }^{35}$. In pharmaceutical areas, borane complexes of $\alpha$-amino acids, aromatic, aliphatic and heterocyclic amines, nucleosides possess a wide range biological activities including antineoplastic, antiviral, hypolipidemic, anti-inflammatory activities, anti-osteoporotic and dopamine receptor antagonist activities ${ }^{36}$.

After the year 1995, two new kinds of borane complexes - metal borane complex and $N$-heterocylic carbene borane complex, have raised unceasing interests in the research field. The first reports on the existence of metal-boron bonds were published in the $1960 \mathrm{~s}^{37}$, however, the identity wasn't confirmed until recently. In the metal borane complexes, borane forms a fourfold coordination with transition metal. The first structurally authenticated borane complexes, namely the metallaboratrane derivatives $\left[\mathrm{M}\left\{\mathrm{B}(\mathrm{mt})_{3}(\mathrm{CO})\left(\mathrm{PPh}_{3}\right)\right](1: \mathrm{M}=\mathrm{Ru}, 2: \mathrm{M}=\mathrm{Os} ; \mathrm{mt}=\right.$ 2-sulfanyl-1-methulimidazole) was prepared by $\left[\mathrm{M}(\mathrm{R}) \mathrm{Cl}(\mathrm{CO})-\left(\mathrm{PPh}_{3}\right)_{2}\right]$ with $\mathrm{Na}\left[\mathrm{HB}(\mathrm{mt})_{3}\right]$ (Scheme 31$)^{38}$. Different metal- 
boryl complexes were prepared as well include dihaloboryl ${ }^{39}$, asymmetric haloboryl ${ }^{40}$, and iminoboryl complexes ${ }^{41}$ (Scheme 32). Further experimental and theoretical studies of the bonding descriptions are going on. Their potential application in stoichiometric or catalytic reactions is likely to emerge shortly.

\section{Scheme 31. Synthesis of zero-valent metallaboratranes}

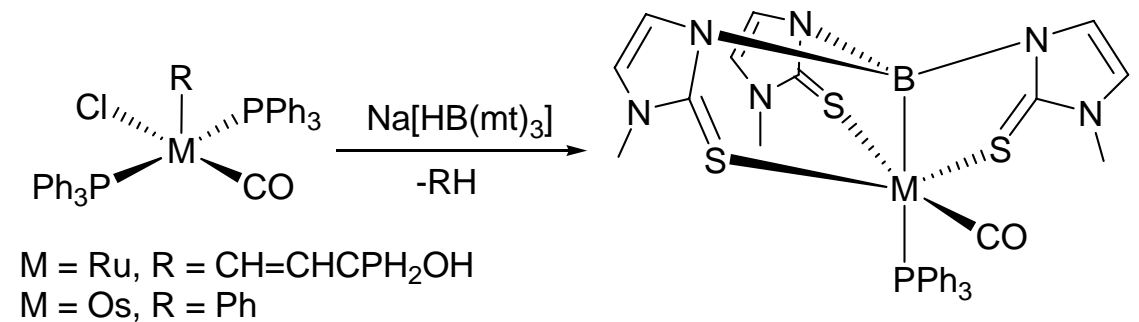

\section{Scheme 32. Examples of Dihaloboryl, Asymmetric Haloboryl, and Iminoboryl Complexes}

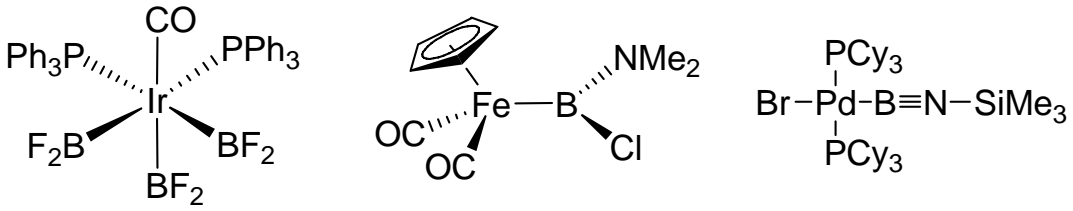

The search for simple, non-toxic, non-explosive compounds to mediate free-radical synthesis has led to a great deal of interests in organic chemistry. Recently, a new direction was developed from the research groups of Fensterbank, Lacote, Malacria, and Curran, who described a marriage of organoborane chemistry with $N$-heterocyclic carbenes. A large variety of scaffolds, including imidazolium, triazolium, and thiazolium derivatives can be used as $\mathrm{NHC}$ ligands ${ }^{42}$ (Scheme 33). The heteroatom donor groups remove the degeneracy of the carbine orbitals and thus enhance the nucleophilicity of the carbon atom. Study shows that the NHC-borane complexes have weakened B-H bonds so that they are better $\mathrm{H}$ donors than amine-boranes or phosphine-boranes. The reactivity was tested as radical reducing reagents with a series of secondary and benzylic xanthates. With AIBN as initiator, reduced products were isolated in reasonable yields ${ }^{43}$ (Scheme 34). Development of practical stereoselective radical reduction protocols by NHC-Borane reagents is under investigation.

\section{Scheme 33. $N$-Heterocyclic Carbene-Borane Complexes}<smiles>[B]C1SC(C)=C(C)N1Cc1ccccc1</smiles><smiles>[B]C1N2CCCC2=NN1c1ccccc1</smiles><smiles>[B]C1N(c2c(C(C)C)cccc2C(C)C)C=CN1c1c(C(C)C)cccc1C(C)(C)C</smiles> 


\section{Scheme 34. Reduction of a Secondary Hexenyl Xanthate with NHC-Borane}

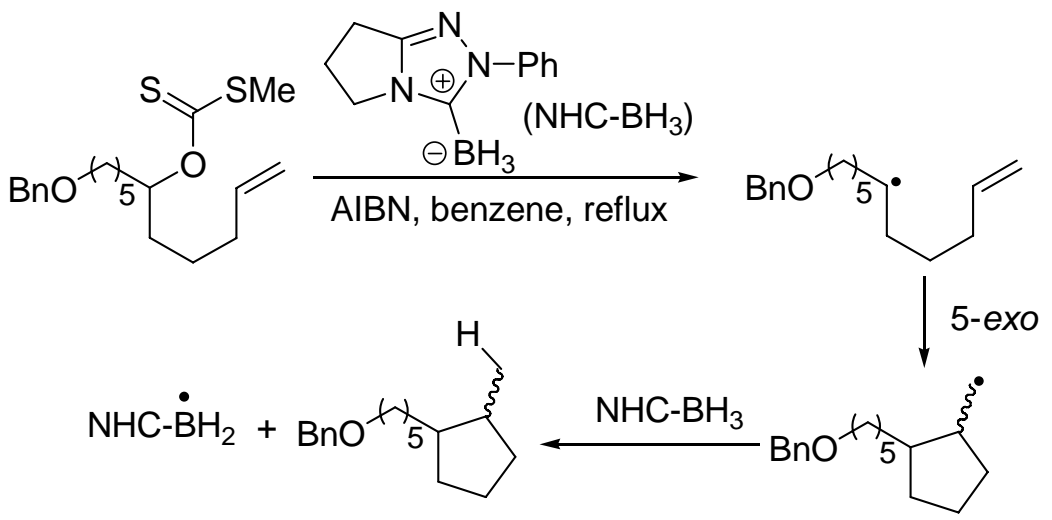

\subsection{Reductive amination by different boranes}

One-pot reductive amination is one of the most useful and versatile methods for the preparation of amines in chemistry and biology ${ }^{44}$. The reaction involves the initial formation of addition product as an aminol intermediate or carbinol amine, which under the suitable reaction conditions dehydrates to form an imine. The imine on protonation forms an iminium ion that subsequently reduced to the respective alkylated amine by a hydride reagent ${ }^{45}$ (Scheme 35$)$. The amines, thus obtained are very useful in industry that have found wide-spread applications as intermediates for pharmaceuticals, dyes, resins, fine chemicals, solvents, textile additives, disinfectants, rubber stabilizers, corrosion inhibitors, and in the manufacture of detergents and plastics. The reductive amination possess several advantages in organic synthesis, such as one pot reaction, mild reaction conditions, wide commercial availability of substrates, use of economy-friendly reagents and so on. However, the reductive amination sometimes is associated with limitations in terms of functional group tolerance, side reactions and reaction conditions. Catalytic reduction is incompatible with compounds having other reducible functional groups such as multiple bonds including cyano, nitro groups. As a result, the choice of the reducing agents is very critical to avoid side reactions and toxicity of the reaction condition.

\section{Scheme 35. Mechanism of Reductive Amination}

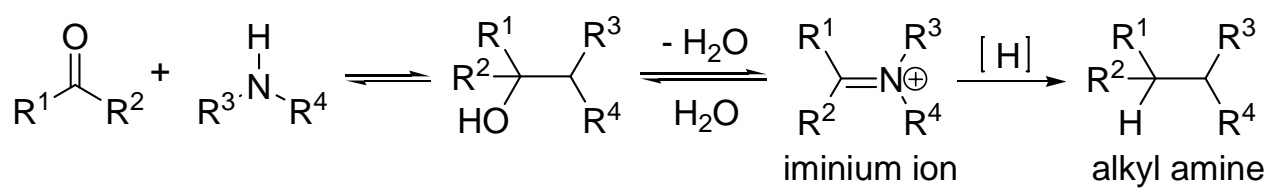

Reductive amination is widely used as the synthetic strategy to synthesize biologically active molecules and synthetic intermediates. Some applications are shown below.

Pyrrolizidinone amino acids are rigid dipeptide surrogates in which the peptide backbone is constrained within a fused 5,5-bicyclic structure. Enantio pure $(3 S, 5 R, 8 S)$ 3-[N-(Boc) amino]-1-aza-bycyclo [3.3.0] octan-2-one 8-carboxylic acid was synthesized via multi-step process involving reductive amination as a key step. In the reductive 
amination, hydrogenation of diamino substrate with Pd-C as catalyst in 9:1 EtOH/AcOH proceeded by cleavage of the phenylfluorenyl groups, intramolecular imine formation, protonation, and hydrogen addition to the iminium ion intermediate (Scheme 36$)^{46}$.

Scheme 36. Synthesis of Pyrrolizidinone Amino Acid via Reductive Amination

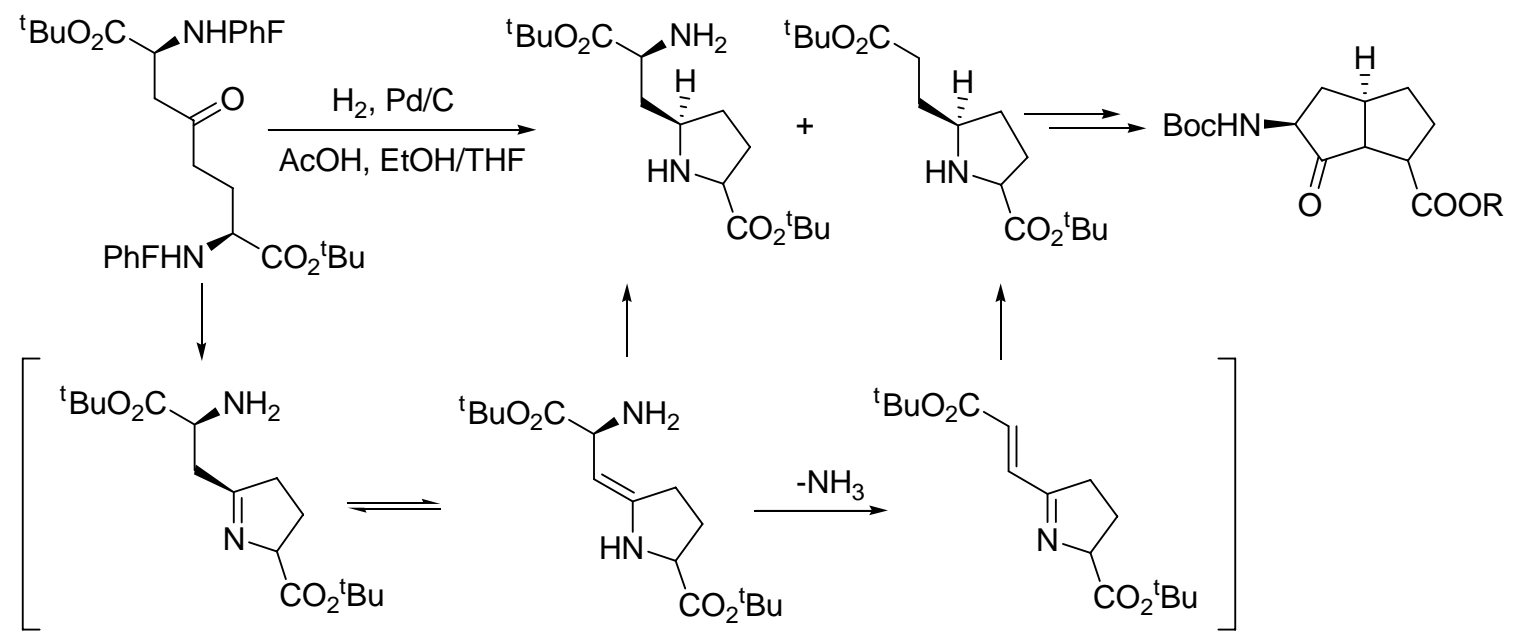

Large alkyl substituents in proteins can be introduced by reductive amination to enhance the hydrophobicity. The free aldehyde form of reducing sugar has been coupled to protein by reductive amination ${ }^{47}$. The reactions of hemoglobin with glucose and glyceraldehydes have been studied in detail in order to understand its nonenzymatic glycosylation. Without the presence of reducing agent, slow Amadori rearrangement happens to give ketoamine as product (Scheme 37).

Scheme 37. Reductive Amination of Sugar and Protein

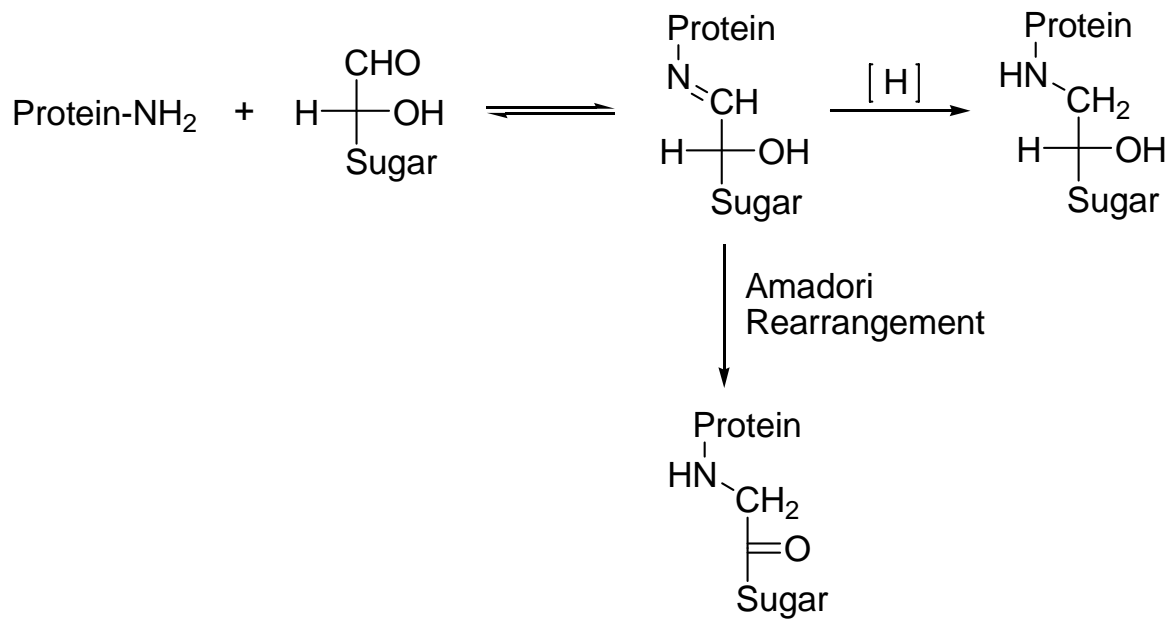

In history, different boranes and borohydrides are used for reductive amination. Decaborane, a mild hydride reagent, has successfully been used by Yoon ${ }^{48}$ in reductive amination of carbonyl compounds to respective amines in moderate yields (Scheme 38). 


\section{Scheme 38. Reductive Amination by Decaborane}

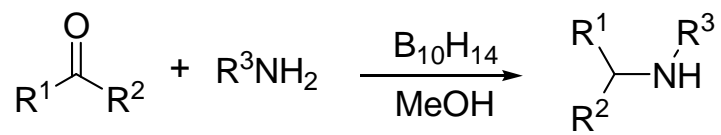

Sodium Borohydride $\left(\mathrm{NaBH}_{4}\right)$ is known to reduce imines in the same manner as it reduces carbonyl group in aldehydes and ketones ${ }^{49}$. However, its application is limited, as it reduces other reducible functionalities present in the same molecule. In order to eliminate the possibility of any other carbonyl group in being reduced to alcohol, it is necessary to convert the carbonyl group completely to imine first, which refers as an indirect reductive amination. Weak electrophilic carbonyl groups, poor nucleophilic amines and sterically hindered reactive centre do not favor the completion of imine formation. In those cases, $\mathrm{NaBH}_{4}$ by itself won't give good results. Different $\mathrm{NaBH}_{4}$ salts are developed to solve the problems.

a. Zinc salt: $\mathrm{ZnCl}_{2}$ and $\mathrm{Zn}\left(\mathrm{CF}_{3} \mathrm{COO}\right)_{2}$ in an inert solvent such as $\mathrm{THF}$ yielded the amines from aldehydes in high yields via the in-situ formation of $\mathrm{Zn}\left(\mathrm{BH}_{4}\right)_{2}{ }^{50}$.

b. Titanium salt: $\mathrm{TiCl}_{4}$ and $\mathrm{Ti}\left(\mathrm{O}^{\mathrm{i}}-\mathrm{Pr}\right)_{4}$ can be used to promote abstraction of water during imine formation ${ }^{51}$. $\mathrm{Ti}(\mathrm{O}-\mathrm{Pr})_{4}-\mathrm{NaBH}_{4}$ has been used by Bhattacharya in such reactions ${ }^{52}$ (Scheme 39).

\section{Scheme 39. Reductive Amination by Ti(IV) Isopropoxide-NaBH 4}

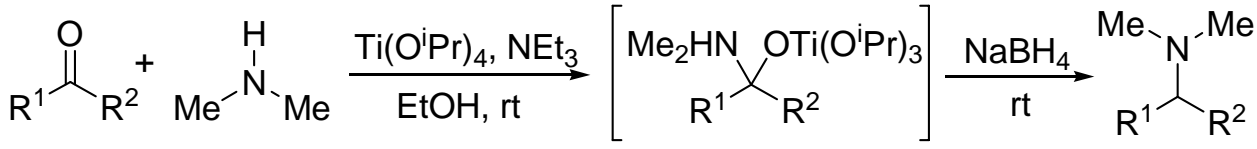

c. Nickle salt: Nickel boride $\left(\mathrm{NiCl}_{2}-\mathrm{NaBH}_{4}\right)$ was generated in situ from nickel chloride hexahydrate and sodium borohydride in Sarma's group. It was used for reductive amination of aldehydes and ketones. Unlike other borane reagents, nickel boride is also well suited to $\alpha, \beta$-unsaturated ketones ${ }^{53}$.

d. $\mathrm{NaBH}_{4}-\mathrm{H}_{3} \mathrm{PW}_{12} \mathrm{O}_{40}{ }^{54}, \mathrm{NaBH}_{4}$-guanidine hydrochloride ${ }^{55}, \mathrm{NaBH}_{4}$ wet claymicrowave ${ }^{56}, \mathrm{NaBH}_{4}$ in micellar media ${ }^{57}$, borohydride exchange $\operatorname{resin}^{58}$ were also introduced for the efficient and selective reductive amination.

Sodium cyanoborohydride $\left(\mathrm{NaBH}_{3} \mathrm{CN}\right)$ has been extensively used in reductive amination with remarkable selectivity ${ }^{59}$. The advantages of $\mathrm{NaBH}_{3} \mathrm{CN}$ include its stability in relatively strong acidic conditions $(\mathrm{pH}=3)$, its solubility in hydroxylic solvents, and its different selectivity at different $\mathrm{pH}$ values. Those unique functions allow a convenient direct reductive amination by sodium cyanoborohydride for many substrates. Similar cyanoborohydride reagents were also developed, such as $\mathrm{LiBH}_{3} \mathrm{CN}^{60}$, (n$\mathrm{Bu})_{4} \mathrm{NBH}_{3} \mathrm{CN}^{61}, \mathrm{ZnCl}_{2}-\mathrm{NaBH}_{3} \mathrm{CN}^{62}, \mathrm{Ti}\left(\mathrm{O}^{\mathrm{i}}-\mathrm{Pr}\right)_{4}-\mathrm{NaBH}_{3} \mathrm{CN}^{63}, \mathrm{Mg}\left(\mathrm{ClO}_{4}\right)_{2}-\mathrm{NaBH}_{3} \mathrm{CN}^{64}$ and so on. 
In 1996, Abdel-Magid reported the comprehensive study of direct and indirect reductive amination by sodium triacetoxyborohydride $\left(\mathrm{NaBH}(\mathrm{OAc})_{3}\right)$ as a mild reducing agent $^{65}$. Aliphatic acyclic and cyclic ketones, aliphatic and aromatic aldehydes, primary and secondary amines including a variety of weakly basic and nonbasic amines are the effective substrates during reductions with $\mathrm{NaBH}(\mathrm{OAc})_{3}$. Limitations include reaction with aromatic and unsaturated ketones and some sterically hindered ketones and amines. Acetic acid has been used as co-catalyst in ketone reactions. The procedure can be carried out in the presence of acid sensitive functional groups such as acetals and ketals, it can also be carried out in the presence of reducible functional groups such as $\mathrm{C}-\mathrm{C}$ multiple bonds, cyano and nitro groups. In comparison with other reductive amination reagents such as $\mathrm{NaBH}_{3} \mathrm{CN}$, pyridine-borane, and catalytic hydrogentation, $\mathrm{NaBH}(\mathrm{OAc})_{3}$ gave better yields and less side products.

Spirocyclic bis-azetidines, an interesting system has been synthesized by the reductive amination of chloro aldehyde with amines through initial formation of aryl amine with $\mathrm{NaBH}(\mathrm{OAc})_{3}$ followed by cyclization ${ }^{66}$ (Scheme 40$)$.

\section{Scheme 40. Reductive Amination by $\mathrm{NaBH}(\mathrm{OAc})_{3}$}
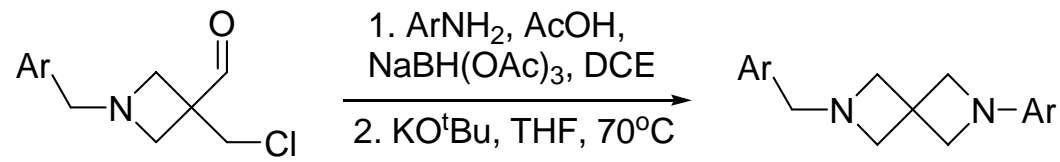

Zinc borohydride $\left(\mathrm{Zn}\left(\mathrm{BH}_{4}\right)_{2}\right)^{67}, \mathrm{Zn}\left(\mathrm{BH}_{4}\right)_{2}-\mathrm{ZnCl}_{2}{ }^{68}$, and $\mathrm{Zn}\left(\mathrm{BH}_{4}\right)_{2}$-silica gel ${ }^{69}$ were also utilized for reductive amination of aldehydes and ketones. Recently, Alinezhad's group have reported thermally stable $\mathrm{Zn}\left(\mathrm{BH}_{4}\right)_{2}-\mathrm{N}$-methylpiperidine for efficient and chemoselective reductive amination under neutral conditions by adding $10 \%$ of hydrochloric acid in methanol ${ }^{70}$.

Firouzabadi has used dichloro-bis(1,4-diazabicyclo[2.2.2] octane) tetrahydroborato zirconium $\left(\mathrm{Zr}\left[\left(\mathrm{BH}_{4}\right)_{2} \mathrm{Cl}_{2}(\text { dabco })_{2}\right]\right)$ for the successful reduction of imines, enamines, reductive amination of aldehydes and ketones, and reductive methylation of amines ${ }^{71}$. This compound is stable under mild aqueous acidic conditions $(\mathrm{pH} 4-6)$ and survives in water for several days without losing its reducing ability.

Bhanage developed a direct reductive amination protocol for aldyheds/ketones using bis(triphenylphosphine) copper(I) tetrahydroborate as a novel reducing agent in the presence of sulfamic acid. The reagent chemoselectively reduces the imine moiety without affecting other reducible functionalities such as chloro, nitro, cyano and $\operatorname{methoxy}^{72}$.

Besides borane metal salts, amine-borane complexes were also used as the reductant in reductive amination. Seo developed a reductive amination of terminal aldehyde carbohydrate with thiol amine by using the reductive coupling reagent dimethylamine borane. Later on the thiol amine was oriented immobilized onto a gold surface ${ }^{73}$ (Scheme 
41). This application was useful for the studies of carbohydrates-biomolecule interactions and carbohydrate sensor or array development for diagnosis and screening.

Scheme 41. Reductive Amination by Dimethylamine Borane

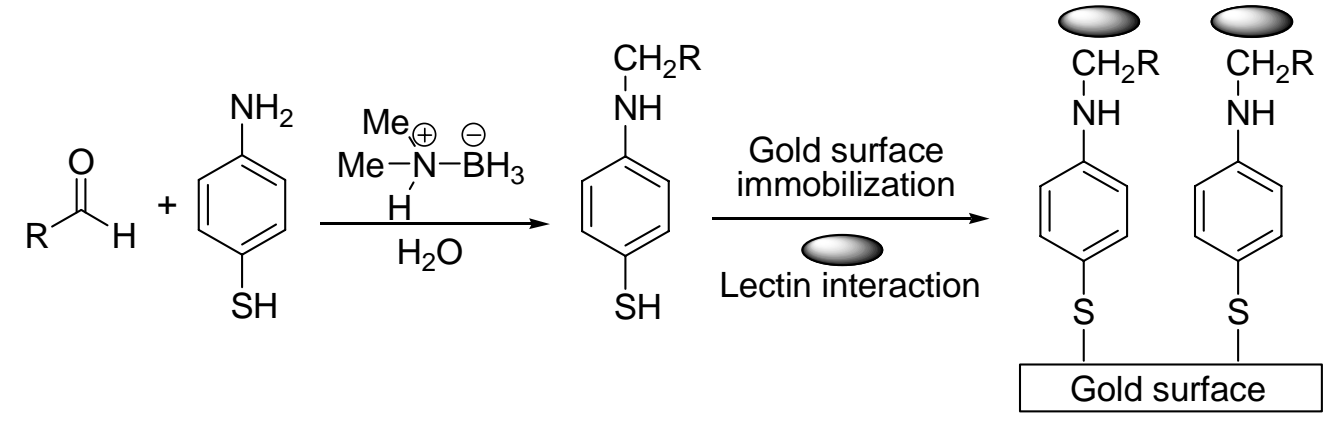

In 1995, DiMare reported in situ reductive amination with different amines and carbonyl compounds using methanolic pyridine-borane (PYB) and molecular sieves ${ }^{74}$. Usually pyridine-borane of commercial origin is utilized without further purification. Due to its instability to heat and violent decompositions, its industrial application is not recommended.

In 2004, Kikugawa reported one-port reductive amination of alkehydes and ketones with amines using 2-picoline-borane (PICB), a cheap and commercially available reducing agent. It is an alternative to $\mathrm{NaBH}_{3} \mathrm{CN}$ and pyridine-borane but superior because of its commercially availability, crystalline nature and relatively better stability. $\mathrm{MeOH} / \mathrm{H}_{2} \mathrm{O}$ has been used as solvent for the reactions and neat conditions also works. The reaction in water offers a great opportunity for green chemistry.

Very recently, Coleridge reported 5-ethyl-2-methylpyridine borane (PEMB) complex as a useful reagent for reductive aminations in methanol or neat conditions ${ }^{75}$. Two of the three hydrides on PEMB are effectively utilized maximizing the economy of the reductant.

Tributyl tin hydride and silicone hydride derivatives, such as $\mathrm{Bu}_{3} \mathrm{SnH}, \mathrm{n}-\mathrm{Bu}_{2} \mathrm{SnClH}-$ HMPA, Et ${ }_{3} \mathrm{SiH}$-TFA, Ti(O $\left.\mathrm{O}^{\mathrm{i}}-\mathrm{Pr}\right)_{4}$-polymethulhydrosiloxane, $\mathrm{PhSiH}_{3}-\mathrm{Bu}_{2} \mathrm{SnCl}_{2}$, also promote effective reductive amination in chemo- and stereoselective manner ${ }^{76-78}$. Hantzsch dihydropyridine with $2 \%$ scandium triflate can perform as organo catalyst in reductive amination ${ }^{79}$. The reduction is completely chemoselective for aldyhyde-derived imines over ketone-derived ones (Scheme 42). MacMillan reported the first organocatalytic reductive amination, a biomimetic reaction that allows the asymmetric coupling of complex with chiral hydrogen-bonding catalysts and Hantzsch esters ${ }^{80}$ (Scheme 43). They proposed that exposure of ketone and amine to a chiral hydrogenbonding catalyst ${ }^{81}$ results in an iminium species formation in presence of a suitable Hantzsch dihydropyridine in asymmetric manner ${ }^{82}$. 


\section{Scheme 42. Reductive Amination by Hantzsch Dihydropyridine}

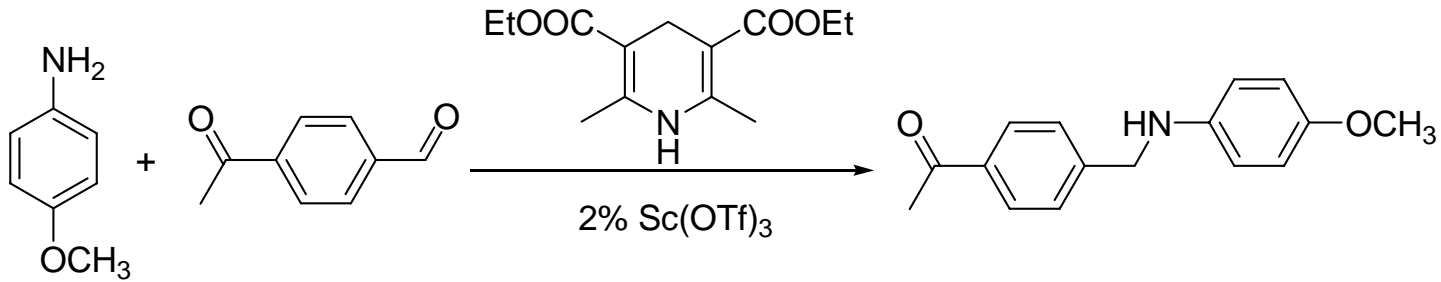

Scheme 43. Asymmetric Reductive Amination by Hantasch Dihydropyridine (HDHP)<smiles>COc1ccc(N[C@@H](C)c2ccccc2)cc1</smiles>

\subsection{Limitation and challenges of reducing agents}

Although different reducing agents for reductive amination were well developed during the recent decades, most of them suffered some limitations. The industrial use of sodium cyano-borohydride is unattractive due to the toxicity and large excess needed. Sodium triacetoxyborohydride, although quite selective for reductive amination, has only one hydride per molecule so that sometimes more than five-fold excess is required for the transformation. Catalytic hydrogenation has limited use with compounds containing multiple $\mathrm{C}-\mathrm{C}$ bonds or hydrogen sensitive functionalities in the substrates. Metal boranes are environmental unfriendly or even high toxic. Some amine-boranes works well, but the poor thermal stability or sensitivity toward moisture are the major drawbacks.

\section{Research Objective}

\subsection{1,2,3-triazole overall view, structures and properties 2.1.1 Synthesis of 4,5-disubstituted 1,2,3-( $\mathrm{NH})$-triazole}

During the past 5 years, the 1,2,3-triazole compounds have been received considerable attention from different research fields such as material science ${ }^{83}$, chemical biology ${ }^{84}$, and medicinal chemistry ${ }^{85}$. This is due to the successful development of 1,2,3-triazole synthesis by $\mathrm{Cu}$-catalyzed azide alkyne 1,3-dipolar cycloaddition system (referred as "click chemistry") (Scheme 44) ${ }^{86}$. However, one limitation of the methodology is the deficient reactivity with unsubstituted azides, which makes the preparation of 1,2,3$(\mathrm{NH})$-triazole a challenge.

\section{Scheme 44. Preparation of 1,2,3-Triazoles via "Click Chemistry"}

$$
\mathrm{R}^{1}=+\mathrm{N}_{3}-\mathrm{R}^{2} \frac{\mathrm{Cu}(\mathrm{I})}{\text { "Click Chemistry" }}
$$


In 2008, our group developed a lewis base-catalyzed three-component cascade reaction for the synthesis of 4,5-disubstitued-1,2,3-(NH)-triazoles ${ }^{87}$. This strategy was based on the previous study of the nitronate formation with Lewis base addition to nitroalkene. Henry reaction of nitroalkene and aryl aldehyde catalyzed by L-proline can give 1,3diene as the key intermediate. With the presence of $\mathrm{NaN}_{3}$, diene was quenched to form 1,2,3-(NH)-triazole product through cycloaddition (Scheme 45). A large number of aryl aldehydes and $\beta$-alkyl nitroalkenes were suitable for this transformation. Various 4,5disubstitued $\mathrm{NH}$-triazoles can be efficiently synthesized in good yields from this mild cascade process. The modifications of the side chain can easily be carried out and used for further study (Scheme 46).

\section{Scheme 45. One Step Formation of 1,2,3-(NH)-Triazole}

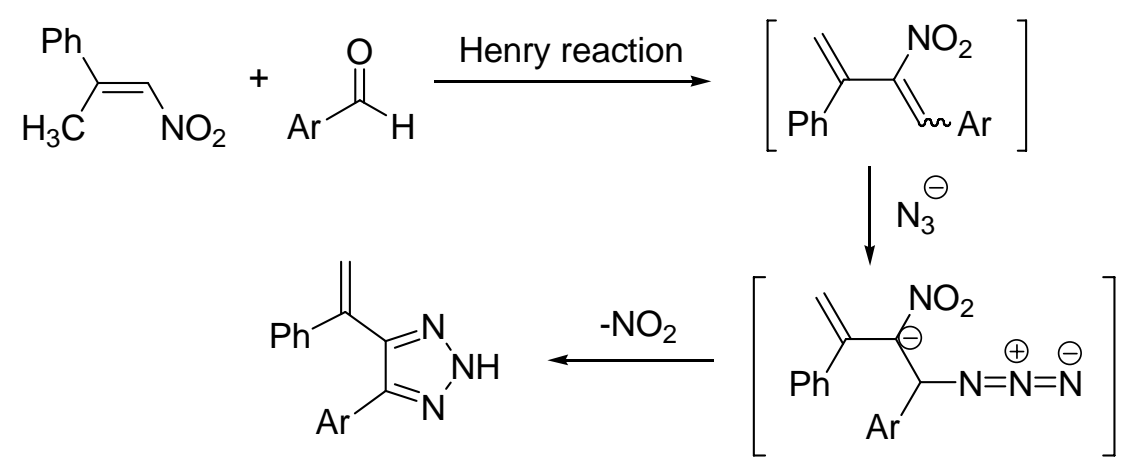

Scheme 46. Side Chain Modification of 1,2,3-(NH)-Triazoles<smiles>C=C(c1ccccc1)c1cc(OCCOC)[nH]n1</smiles><smiles>CC(c1ccccc1)c1n[nH]nc1-c1ccccc1</smiles><smiles>C=C(c1ccccc1)c1n[nH]nc1-c1ccccc1</smiles>

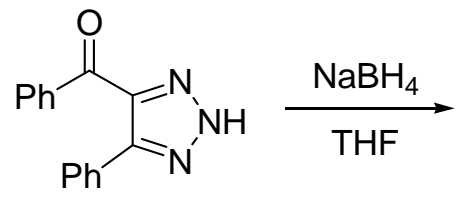<smiles>OC(c1ccccc1)c1n[nH]nc1-c1ccccc1</smiles>

\subsubsection{Synthesis of metal-triazole complex}

Trizaoles are considered as potential good ligands in coordination with transition metals due to its better $\sigma$-donating nitrogen and $\pi$-receiving aromatic ring system. Recently, our group further confirmed the theory by having our 1,2,3-(NH)-triazoles to react with rhodium and gold cations to form complexes.

4,5-disubstituted $\mathrm{NH}$-1,2,3-triazoles were used to coordinate with $\mathrm{Rh}(\mathrm{I})$ to form a new class of triazole-bridged $[\mathrm{Rh}(\mathrm{COD})(\text { triazole })]_{2}$ complexes $(\text { Scheme } 47)^{88}$. The crystal structures were studied by X-ray crystallography. These new complexes showed improved stability toward air and moisture. The reactivity was tested by typical Pauson- 
Khand reactions (Scheme 48). Interestingly, bonding sites can be switched to different nitrogens when C-4 substituted group varies.

\section{Scheme 47. Preparation of $[\mathrm{Rh}(\mathrm{COD})(\text { Triazole })]_{2}$ Complex}

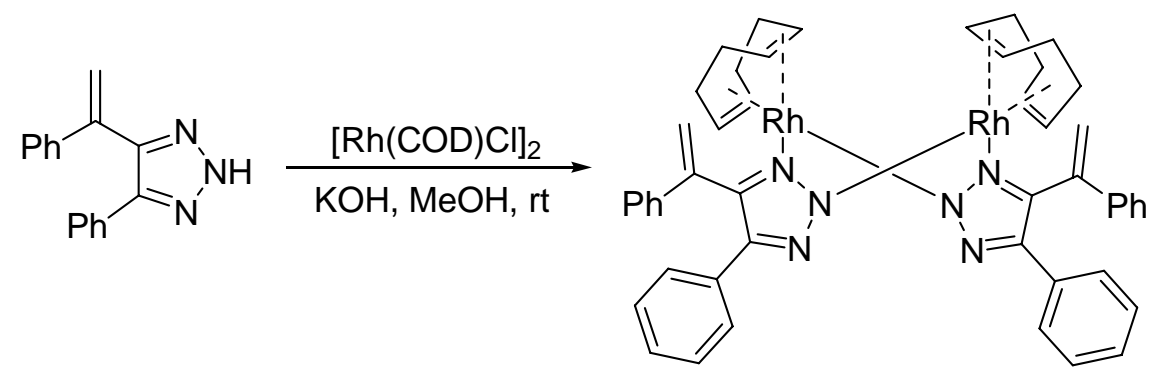

\section{Scheme 48. Triazole-Rh(I) Complex Catalyzed Pauson-Khand Reactions}

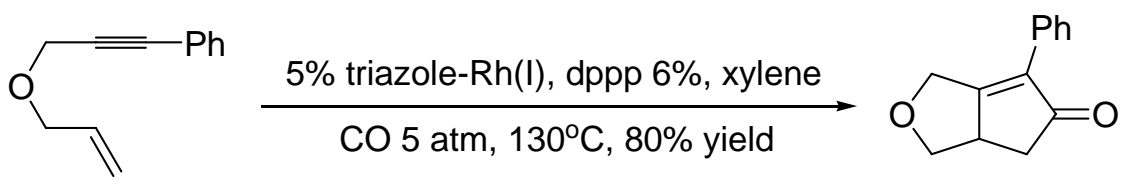

A series of 1,2,3-triazole-Au(I) complexes were synthesized via similar method ${ }^{89}$. Structures were confirmed by X-ray crystallography. As we expected, they possessed better thermal and moist stability than literature reported Au catalysts. As a result, the challenging intermolecular internal alkyne hydroaminations were successful achieved at a higher reaction temperature, giving excellent yields with low catalyst loading (Scheme 49).

Scheme 49. Triazole-Au(I) Catalyzed Intermolecular Hydroamination

$$
\mathrm{R}^{1}=\mathrm{R}^{2}+\mathrm{H}_{2} \mathrm{~N}-\mathrm{R}^{3} \frac{\text { 1. Au cat., } \mathrm{H}_{3} \mathrm{PO}_{4} 12 \mathrm{WO}_{3}, \mathrm{Tol} \text {., } 80^{\circ} \mathrm{C}}{\text { 2. } \mathrm{BH}_{3}, \mathrm{THF}}
$$

\subsection{Design of triazole-borane synthesis}

Our interest in developing 1,2,3-triazole-coordinated complexes was initiated by our recent success with a metal-free 1,2,3-NH-triazole synthesis and post-triazole regioselective derivatization. Comparing with other $\mathrm{N}$-heterocyclic aromatic compounds, 1,2,3-triazoles possess unique functions include: high polarity and electron density on the nitrogen (more nucleophilic and less basic) allowing them to coordinate well with Lewis acids, while a lower LUMO in the aromatic ring enhanceing back bonding, giving stable triazole-metal binding. Triazole- $\mathrm{Rh}(\mathrm{I})$ and trizole- $\mathrm{Au}(\mathrm{I})$ complexes were prepared, 
provided much better stability toward air, moisture and heat. Therefore, we wondered whether 1,2,3-triazoles could interact with Lewis acid borane to form effective triazoleborane complex for further reduction application.

\section{Results and Discussion}

\subsection{Synthesis of triazole-borane complex}

The reaction results of different triazoles with $\mathrm{BH}_{3}$-THF is shown in Table 3 .

\section{Table 3. Preparation of Triazole-Borane Complexes}

stable white solid


The reactions between $\mathrm{NH}$-triazoles (6a and $\mathbf{6 f}$ ) and $\mathrm{BH}_{3}$-THF gave complex mixtures, whose structure cannot be identified at this moment. This was probably due to the multiple nitrogen binding sites on the triazoles and possible formation of $\mathrm{B}-\mathrm{H}-\mathrm{B} 3 \mathrm{c} 2 \mathrm{e}$ bond. The N-2 substituted benzyl triazoles (6c, 6e and $\mathbf{6 h}$ ) indicated no complex formation even when treated at a higher temperature $\left(50{ }^{\circ} \mathrm{C}\right)$. This lack of coordination was likely caused by the steric hindrance of the N-2 substituted groups. The 1,4disubstituted triazole $\mathbf{6 g}$ is the popular triazole derivative product prepared from "clickchemistry" ${ }^{\prime 3}$. Unfortunately, the reaction between $\mathbf{6 g}$ and $\mathrm{BH}_{3}$-THF gave multiple complexes with low reaction rate (more than 12 hours at room temperature) and the complexes decomposed during attempt of isolation (Table 3 ).

In order to decrease the steric hindrance on the N-2 position, we examined the N-1 substituted benzotriazoles $\mathbf{6 b}$ and $\mathbf{6 d}$ react with $\mathrm{BH}_{3}$-THF. To our great pleasure, the triazole borane complexes $\mathbf{7 a}$ and $\mathbf{7 b}$ were formed as white solids in nearly quantitative yields. The structure of 7a was confirmed by X-ray crystallography with $\mathrm{BH}_{3}$ bond on the N-3 position as expected. Notably, the triazole-boranes were very stable toward air and moisture and can even be purified by column chromatography. The complexes were also thermally stable as high as $80{ }^{\circ} \mathrm{C}$ (no decomposition).

\subsection{Reductive amination of aldehyde and condition screening}

With these new triazole-boranes 7a and $\mathbf{7 b}$ in hand, we then explored their reactivity as reductants. The transformation that particularly interested us was the aldehyde and ketone reductive amination, a very important reaction in organic synthesis especially for biological related systems. As a very attractive approach for bio-elongation, the key concerns regarding "good" reductive amination reagents are: a) good chemoselectivity (selectively reduce imine rather than aldehydes and ketones); b) bio-compatibility ("green" reaction conditions), and c) stability in protic solvents. Among these factors, the hydride stability under acidic conditions is particularly challenging due to $\mathrm{H}_{2}$ formation. As a result, reductive amination of ketones is one extremely difficult task, since acid activation of ketone is often required for the effective imine formation.

To evaluate the reactivity of triazole boranes, aldehyde 8a and aniline 9a were first applied as shown in Table 4.

Table 4. Condition Screening of Aldehyde Reductive Amination<smiles>Nc1ccccc1</smiles> 


\begin{tabular}{cccccc}
\hline Entry & Tria-Borane & Solvent & Temp & Time(h) & Yield(\%) \\
\hline 1 & 7a (0.7 eq.) & $\mathrm{CH}_{2} \mathrm{Cl}_{2}$ & $\mathrm{rt}$ & 5 & 99 \\
2 & 7b (0.7 eq.) & $\mathrm{CH}_{2} \mathrm{Cl}_{2}$ & $\mathrm{rt}$ & 3.5 & 99 \\
3 & 7b (0.7 eq.) & $\mathrm{DMSO}$ & $\mathrm{rt}$ & 0.5 & 95 \\
4 & 7b (0.7 eq.) & $\mathrm{DMF}$ & $\mathrm{rt}$ & 5 & 91 \\
5 & 7b (0.7 eq.) & $\mathrm{THF}$ & $\mathrm{rt}$ & $15 \mathrm{~min}$ & 72 \\
6 & 7b (0.7 eq.) & Toluene & $\mathrm{rt}$ & 1.5 & 99 \\
7 & 7b (0.7 eq.) & $\mathrm{CH}_{3} \mathrm{CN}$ & $\mathrm{rt}$ & 4 & 99 \\
8 & 7b (0.7 eq.) & $\mathrm{MeOH}$ & $\mathrm{rt}$ & 2 & 99 \\
9 & 7b (0.7 eq.) & neat & $\mathrm{rt}$ & $5 \mathrm{~min}$ & 94 \\
10 & 7b (0.4 eq.) & $\mathrm{DCE}$ & $\mathrm{rt}$ & 3 & 99 \\
11 & 7b (0.4 eq.) & $\mathrm{DCE}$ & $60^{\circ} \mathrm{C}$ & 0.5 & 99 \\
12 & 7b (0.4 eq.) & $\mathrm{MeOH}$ & $\mathrm{rt}$ & 1 & 48 \\
\hline
\end{tabular}

Reactions were carried out by mixing 8a (1.05 equiv), 9a (1.0 equiv), and 7 together under different conditions. The triazole boranes showed excellent reactivity toward aldehyde reductive amination in various solvents, giving near quantitative yields in most of the cases. Although both $\mathbf{7 a}$ and $\mathbf{7 b}$ were stable triazole borane complexes, $\mathbf{7 b}$ showed improved solubility in organic solvents. As a result, a slightly improved reaction rate was observed (entries 1 and 2). The reaction in THF gave lower yield, which was likely due to the solvent coordination with borane that led to side reactions. Notably, these new borane complexes indicated great stability in protic solvent $\mathrm{MeOH}$ or at a higher temperature (entries 8 and 11). Impressively, the reaction gave quantitative yield in DCE even with only 0.4 equiv of reductant (a slight increase of reductant was needed for protic solvent, entries 8 and 12). Considering that 1 equiv of water was produced in this process, the fact that only the theoretical limit amount ( 0.33 equiv) of borane was needed indicated the extremely high hydride transfer efficiency and superior stability of the triazole-borane reductants. Representative aldehydes and amines were applied as shown in Table 5.

Table 5. Reductive Amination of Aldehydes

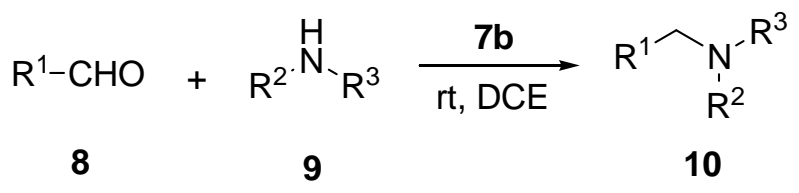

Entry Aldehyde


3<smiles>O=Cc1ccccc1</smiles>

4<smiles>O=Cc1ccc(Cl)cc1</smiles>

5<smiles>O=Cc1ccc(Cl)cc1</smiles>

6<smiles>O=Cc1ccc(Cl)cc1</smiles><smiles>NCc1ccccc1</smiles>

4<smiles>COc1ccc(NCc2ccc(Cl)cc2)cc1</smiles>

6<smiles>Fc1ccc(NCc2ccc(Cl)cc2)cc1</smiles>

7<smiles>O=Cc1ccc(Cl)cc1</smiles>

8<smiles>O=Cc1ccc([N+](=O)[O-])cc1</smiles><smiles>COc1ccc(CN)cc1</smiles>
3<smiles>COc1ccc(CN)cc1</smiles><smiles>COc1ccc(CNCc2ccc(Cl)cc2)cc1</smiles><smiles>COc1ccc(CNCc2ccc([N+](=O)[O-])cc2)cc1</smiles>
82

4<smiles>CCCCNCc1ccc(Cl)cc1</smiles>

4<smiles>Clc1ccc(CN2CCCC2)cc1</smiles>
95<smiles>CN(Cc1ccc(Cl)cc1)c1ccccc1</smiles>

3 


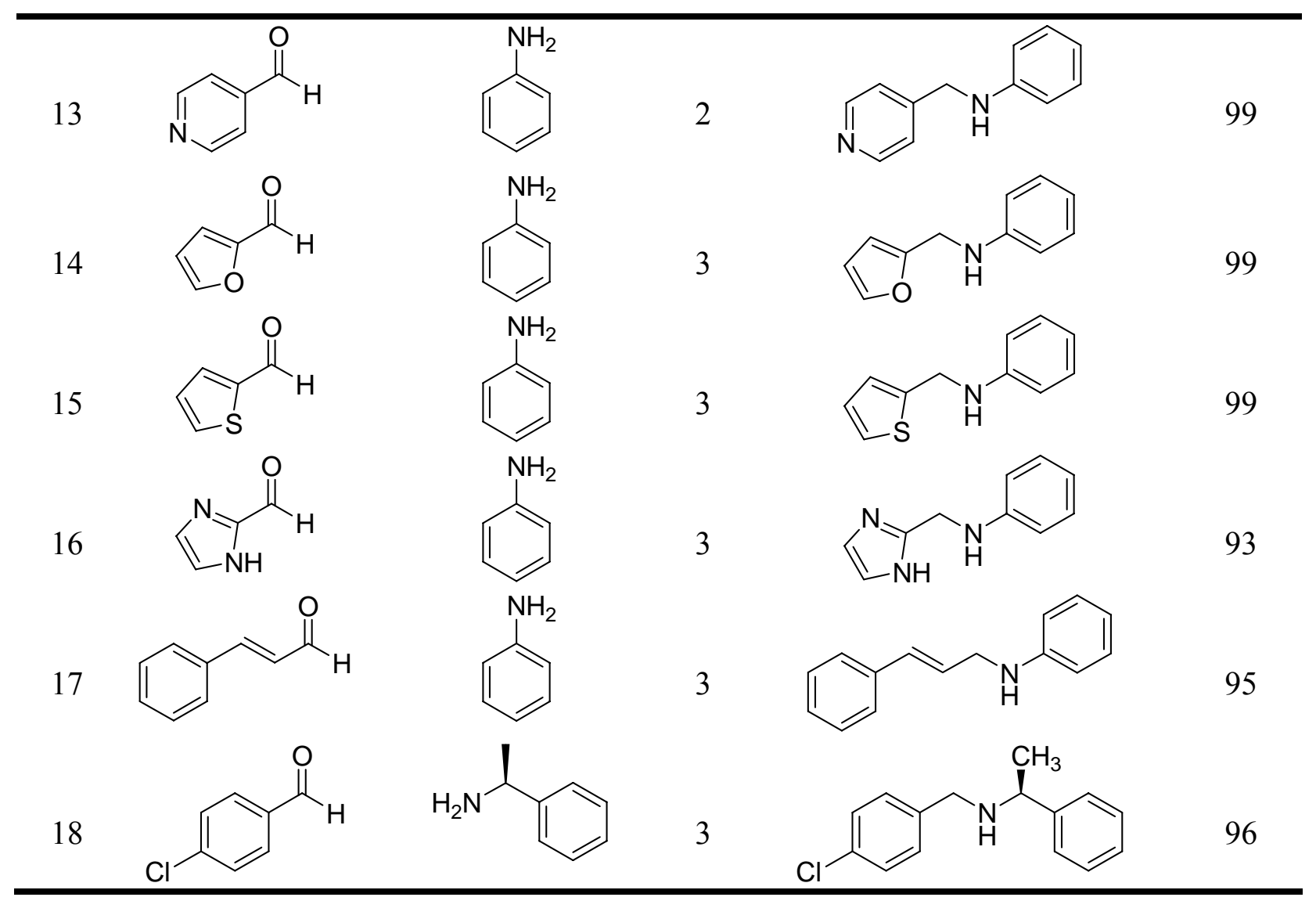

The results demonstrated that this transformation is suitable for a large variety of aldehydes (aromatic, aliphatic, unsaturated and heteroaromatic) and amines (aromatic, aliphatic and secondary amines). Excellent yields were obtained for almost all cases. Meanwhile, the benzotriazole by-product could be recovered in nearly quantative yield.

\subsection{Reductive amination of ketone}

Encouraged by this success, we extended the investigation to ketones. Since acids were often required for the imine formation, $30 \%$ of $\mathrm{AcOH}$ was added as the catalyst (no reaction was observed without acid catalyst at room temperature for $24 \mathrm{hrs}$ ). Again, effective reductive amination of ketone was achieved using triazole-boranes with a slightly higher loading of reductant (0.8-1.2 equiv). Moreover, this ketone reductive amination could also be achieved by increasing the reaction temperature without further addition of acid catalyst (condition B). Reaction substrates are shown in Scheme 50. 


\section{Scheme 50. Reductive Amination of Ketones}

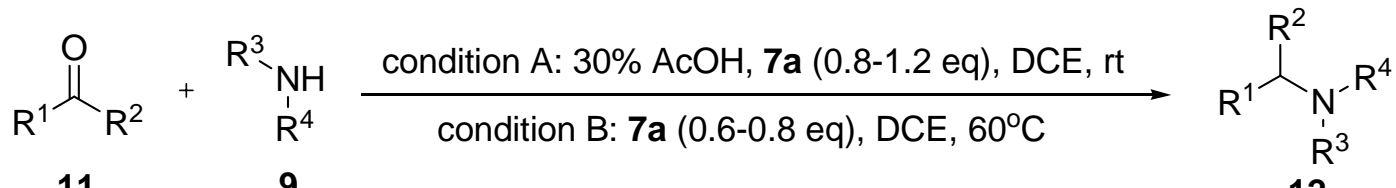

11<smiles>Cc1ccc(NC2CCCCC2)cc1</smiles>

A: $5 \mathrm{~h}, 99 \%$

B: $1 \mathrm{~h}, 99 \%$<smiles>CC(Nc1ccccc1)c1ccccc1</smiles>

A:10h, $99 \%$ B: 6 h, $99 \%$<smiles>c1ccc(CNC2CCCCC2)cc1</smiles>

A: $3 \mathrm{~h}, 92 \%$

B: $2 \mathrm{~h}, 95 \%$<smiles>CC(NCc1ccccc1)c1ccccc1</smiles>

A: $5 \mathrm{~h}, 85 \%$

B: $4.5 \mathrm{~h}, 87 \%$<smiles>CN(c1ccccc1)C1CCCCC1</smiles>

A: $8 \mathrm{~h}, 99 \%$

B: $4 \mathrm{~h}, 99 \%$<smiles>CC(Nc1ccccc1)c1ccco1</smiles>

A: $5 \mathrm{~h}, 47 \%$

B: $3 \mathrm{~h}, 96 \%$

As shown in Scheme 50, this reaction was suitable for primary amine, secondary amine and aniline. Meanwhile, the two different reaction conditions provided orthogonal approaches for sensitive substrates. For examples, in the synthesis of $12 \mathrm{f}$, the furanyl ketone decomposed under acidic conditions. Therefore, using condition A gave $12 \mathrm{f}$ in less than 50\% yields along with ketone decomposition by-products. Application of condition B could help to avoid the decomposition of ketone, giving $12 \mathrm{f}$ in excellent yield. The enone substrate has also been investigated (cyclohexenone). A mixture of different reduction products (including the desired allylic amine) was observed. The lack of chemo-selectivity was likely caused by the harsher conditions. Benzophenone also didn't work well due to its large steric hindrance of the two phenyl groups. However, when compared with other reductants, triazole-borane showed much better stability and reactivity in different ketone examples.

Overall, to the best of our knowledge, the triazole-borane was by far one of the most efficient metal-free reagents for the challenging ketone reductive amination. With clear evidence for improved proton and thermal stability of TAB, we then applied this reagent to the unprotected amino acid reductive amination in water.

\subsection{Reductive amination of unprotected amino acids}

To increase the solubility of amino acid in water, $30 \% \mathrm{Na}_{2} \mathrm{CO}_{3}$ was added (Scheme 51). This modification helped the further evaluation of the triazole-borane reductant under basic conditions. As anticipated, good yields were obtained. Notably, this reaction tolerated functional groups that may potentially coordinate with borane, such as imidazole and sulfur (14b and 14c), which further enhanced the synthetic utility of the reductant. 


\section{Scheme 51. Reductive Amination of Amino Acid}

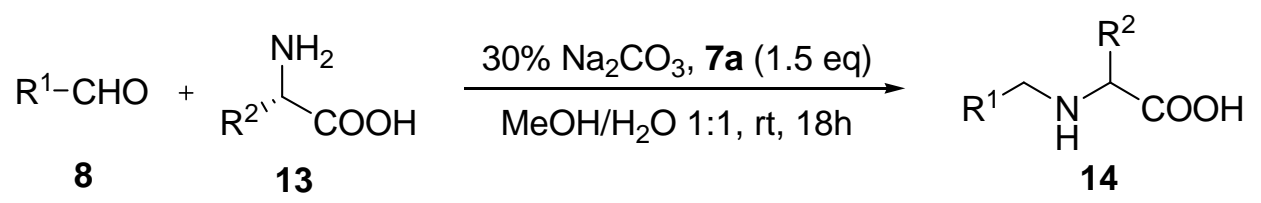<smiles>CC(C)C[C@H](NCc1ccc2ccccc2c1)C(=O)O</smiles>

$80 \%$<smiles>CSCC[C@H](NCc1ccc(Cl)cc1)C(=O)O</smiles>

$87 \%$<smiles>O=C(O)[C@H](Cc1ccc(Cl)cc1)NCc1ncc[nH]1</smiles>

$84 \%$<smiles>O=C(O)CNCc1ccc(Cl)cc1</smiles>

$75 \%$

\subsection{Possible future studies}

In the future, several directions can be dug into for the novel triazole-borane complexes: 1) Reactions will be designed for the mechanistic study of the triazole-borane reductions;

2) Asymmetric reductive amination by chiral triazole-boranes;

3) Design and synthesis of water soluble triazole-boranes for biological applications.

\section{Conclusion}

In conclusion, the triazole-boranes were successfully prepared and applied as reductants in ketone/aldehyde reductive amination. Compared with literature reported systems, the triazole-boranes showed clear advantages regarding efficiency, proton and thermal stability, which made them new practical reagents for related chemical and biological research. Detailed studies regarding reaction mechanism (borane dissociation process) and application of this new reagent for other important transformations are currently under investigation in our group. 


\section{Part III \\ Experimental Section}

\section{General Methods and Materials:}

Unless otherwise noted, all commercial reagents and solvents were obtained from the commercial provider and used without further purification. Air and/or moisture-sensitive reactions were carried out under an atmosphere of nitrogen using oven/flame-dried glassware and standard syringe/septa techniques. ${ }^{1} \mathrm{H}-\mathrm{NMR}$ and ${ }^{13} \mathrm{C}-\mathrm{NMR}$ spectra were recorded on Joel $270 \mathrm{MHz}$ and Varian $600 \mathrm{MHz}$ spectrometers. Chemical shifts were reported relative to internal tetramethysilane $(\delta 0.00 \mathrm{ppm})$ or $\mathrm{CDCl}_{3}(\delta 7.26 \mathrm{ppm})$ for ${ }^{1} \mathrm{H}$ and $\mathrm{CDCl}_{3}(\delta 77.0 \mathrm{ppm})$ for ${ }^{13} \mathrm{C}$ or $\mathrm{CD}_{3} \mathrm{OD}(\delta 4.87,3.31 \mathrm{ppm})$ for ${ }^{1} \mathrm{H}$ and $\mathrm{CD}_{3} \mathrm{OD}(\delta 49.1 \mathrm{ppm})$ for ${ }^{13} \mathrm{C}$. Melting points were measured on a Mel-Temp 1001D apparatus and uncorrected. HRMS were recorded on LTQFTUHRA spectrometer. Flash column chromatography was performed on 230-430 mesh silica gel. Analytical thin layer chromatography was performed with precoated glass baked plates $(250 \mu)$ and visualized by fluorescence and by charring after treatment with potassium permanganate stain.

The nitroalkene starting materials 1a-1e were prepared according to reported procedures: 1) Ohta, H.; Kobayashi, N.; Ozaki, K. J. Org. Chem. 1989, 54, 1802-1804. 2) Matin, N. J. A.; Ozores, L.; List, B. J. Am. Chem. Soc. 2007, 129, 8976-8977. Nitroalkene 1f-1h were prepared according to reported procedure: 3) Jang, Y. J.; Lin, W. W.; Shih, Y. K.; Liu, J. T.; Hwang, M. H.; Yao, C. F. Tetrahedron, 2003, 59, 4979-4992. Vinyl esters 4b-4d were prepared according to reported procedures: Bedoukian, P. Z. J. Am. Chem. Soc. 1944, 66, 1325-1327.

Triazoles 6a-6h were prepared according to the literature: Liu, Y.; Yan, W.; Chen, Y.; Petersen, J. L.; Shi, X. Org. Lett. 2008, 10, 5389--5392.

\section{General Procedure for synthesis of Isoxazoline- $N$-Oxide :}<smiles>C/C(=C/[N+](=O)[O-])c1ccccc1</smiles>

$1 \mathrm{a}$<smiles>C=COC(C)=O</smiles>

$4 a$

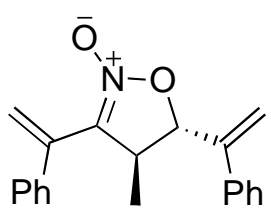

$3 a$

To a $25 \mathrm{ml}$ vial was added L-Proline $(23 \mathrm{mg}, 0.2 \mathrm{mmol})$ and Sodium acetate $(82 \mathrm{mg}, 1 \mathrm{mmol})$ in $10 \mathrm{ml}$ DMSO, then vinyl ester 4a (172 mg, $2.0 \mathrm{mmol})$ and nitroalkene 1a (163 mg, $1.0 \mathrm{mmol})$ were added sequent. The resulting reaction mixture was stirred at room temperature and monitored by TLC. After the reaction completed, the resulting brown solution was diluted with ethyl acetate, and washed with water $(30 \mathrm{mlx} 3)$. The aqueous phase was extracted with ethyl acetate and the combined organic phase was washed with water and brine, then dried over $\mathrm{Na}_{2} \mathrm{SO}_{4}$. After remove solvent by evaporator, the residue product was purified by flash silica gel chromatography gave the Isoxazoline-N-Oxide 3a as colorless oil in $88 \%$ yield. 


\section{General Procedure for transformation Isoxazoline- $N$-oxide to Isoxazoline}

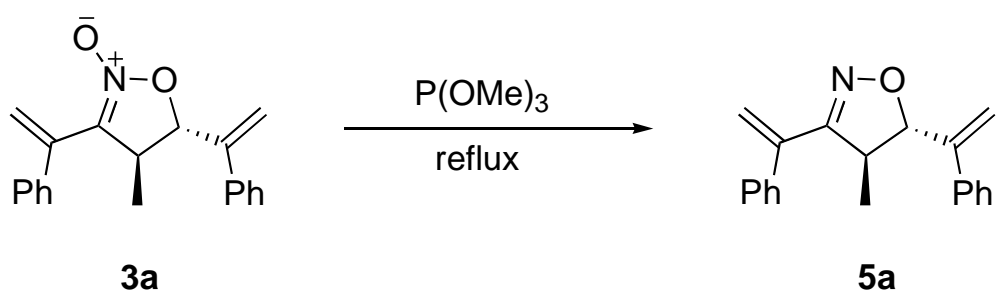

The Isoxazoline-N-oxide 3a ( $305 \mathrm{mg}, 1 \mathrm{mmol}$ ) was dissolved in $8 \mathrm{ml}$ trimethyl phosphite in a flask equipped with a condenser. The solution was well degassed and heated to reflux under $\mathrm{N}_{2}$. After $12 \mathrm{~h}$ the TLC analysis (hexane / ethyl acetate $=7 / 1$ ) revealed that the starting material was consumed. The reaction was cooled to $0{ }^{\circ} \mathrm{C}$ then diethyl ether was added and the solution was washed with $1 \mathrm{~N} \mathrm{HCl}(3 \times 10 \mathrm{ml})$, water $(10 \mathrm{ml})$. The organic layer was dried over $\mathrm{Na}_{2} \mathrm{SO}_{4}$ and concentrated in vacuo. The crude product was purified by flash silica gel chromatography gave the Isoxazoline $5 \mathbf{a}$ as colorless oil in $81 \%$ yield.

Compound $\mathbf{5 b}$ was synthesized by the same procedure as above.

\section{General Procedure for transformation Isoxazoline- $N$-oxide to Isoxazole}

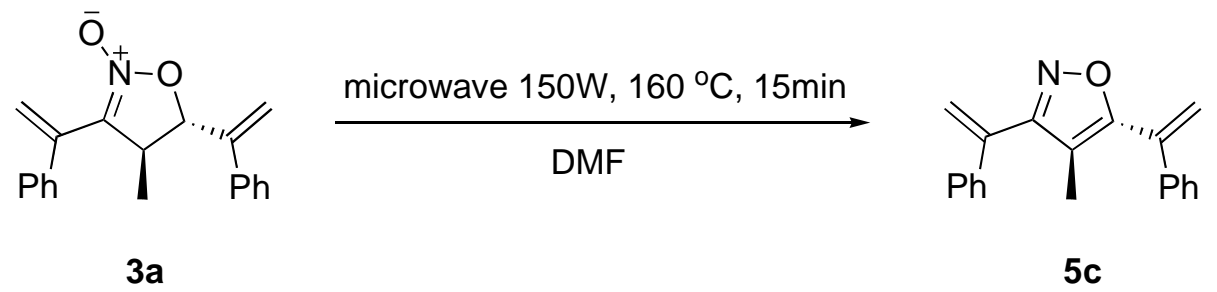

The starting material 3a (100 mg, $0.34 \mathrm{mmol})$ was dissolved in $2 \mathrm{ml}$ DMF. Then the sealed reaction tube was heated to $160^{\circ} \mathrm{C}$ by microwave $(150 \mathrm{~W})$ for $15 \mathrm{~min}$. After cooled to room temperature, the solution was diluted with ethyl acetate $(30 \mathrm{ml})$ and washed with water and brine. The organic layer was dried over $\mathrm{Na}_{2} \mathrm{SO}_{4}$ and concentrated in vacuo. The crude product was purified by flash silica gel chromatography gave the Isoxazole 5c as colorless oil in $71 \%$ yield.

\section{$\underline{\text { General Procedure for transformation } 5 b \text { to } 5 d}$}<smiles>C[C@H]1C(C2=CCCCC2)=NO[C@H]1C1=CCCCC1</smiles>

$5 b$

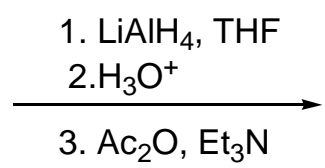

3. $\mathrm{Ac}_{2} \mathrm{O}, \mathrm{Et}_{3} \mathrm{~N}$<smiles>C[C@H](NC(=O)O)[C@@H](O)C1=CCCCC1</smiles>

$5 d$ 
$\mathrm{LiAlH}_{4}(222 \mathrm{mg}, 6 \mathrm{mmol})$ was suspended in $6 \mathrm{ml} \mathrm{THF}$ under $\mathrm{N}_{2}$. Then Isoxazoline $5 \mathbf{b}$ ( $245 \mathrm{mg}, 1$ $\mathrm{mmol}$ ) in $5 \mathrm{ml}$ THF was added dropwise at $0{ }^{\circ} \mathrm{C}$. After $2 \mathrm{~h}$ the reaction was allowed to warm to room temperature and keep stirring for another $12 \mathrm{~h}$. TLC analysis (hexane / ethyl acetate $=5 / 1$ ) revealed that the starting material was consumed. Then $5.0 \mathrm{ml}$ of $6 \mathrm{~N} \mathrm{HCl}$ was added dropwise at $-5{ }^{\circ} \mathrm{C}$ and the mixture was extracted several times with ethyl acetate, the organic layer was washed with water and brine, dried over $\mathrm{Na}_{2} \mathrm{SO}_{4}$ and concentrated in vacuo. The crude product was used directly for the next step.

The previous product was dissolved in $5 \mathrm{ml} \mathrm{Et}_{3} \mathrm{~N}$, then $\mathrm{Ac}_{2} \mathrm{O}(0.5 \mathrm{ml}, 5 \mathrm{mmol})$ was added dropwise at room temperature. After $12 \mathrm{~h}$ the reaction mixture was concentrated in vacuo, diluted with $\mathrm{CH} 2 \mathrm{Cl} 2$ and washed with saturated $\mathrm{NaHCO} 3$, the organic layer was washed with water and brine, dried over $\mathrm{Na}_{2} \mathrm{SO}_{4}$. After remove solvent by evaporator, the residue product was purified by flash silica gel chromatography gave the $\mathrm{N}$-1,3-dicyclohexenyl-3-hydroxy-2methylpropyl) acetamide $\mathbf{5 d}$ as colorless oil in $65 \%$ yield

\section{Procedure for deuterium study and ${ }^{1} \mathrm{H}$ NMR spectrum}

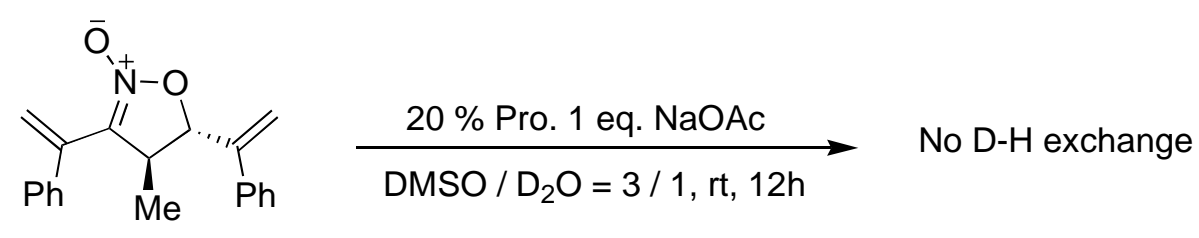

$3 a$

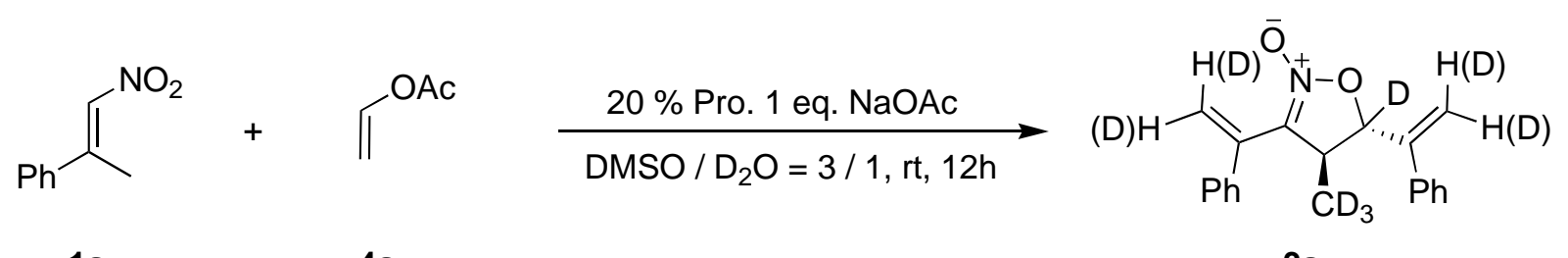

$1 a$

$4 a$

$3 a$

To a $25 \mathrm{ml}$ vial was added L-Proline $(23 \mathrm{mg}, 0.2 \mathrm{mmol})$ and Sodium acetate $(82 \mathrm{mg}, 1 \mathrm{mmol})$ in the mixture of $7.5 \mathrm{ml}$ DMSO and $2.5 \mathrm{ml} \mathrm{D} \mathrm{D}_{2} \mathrm{O}$, then vinyl ester $4 \mathrm{a}(172 \mathrm{mg}, 2.0 \mathrm{mmol})$ and nitroalkene 1a $(163 \mathrm{mg}, 1.0 \mathrm{mmol})$ were added sequent. The resulting reaction mixture was stirred at room temperature and monitored by TLC. After the staring material consumed, the reaction was worked up using the same procedure described above for the synthesis of isoxazoline- $N$-oxide, gave the deuterated product in $35 \%$ yield.

The compared spectrums are listed blow. 

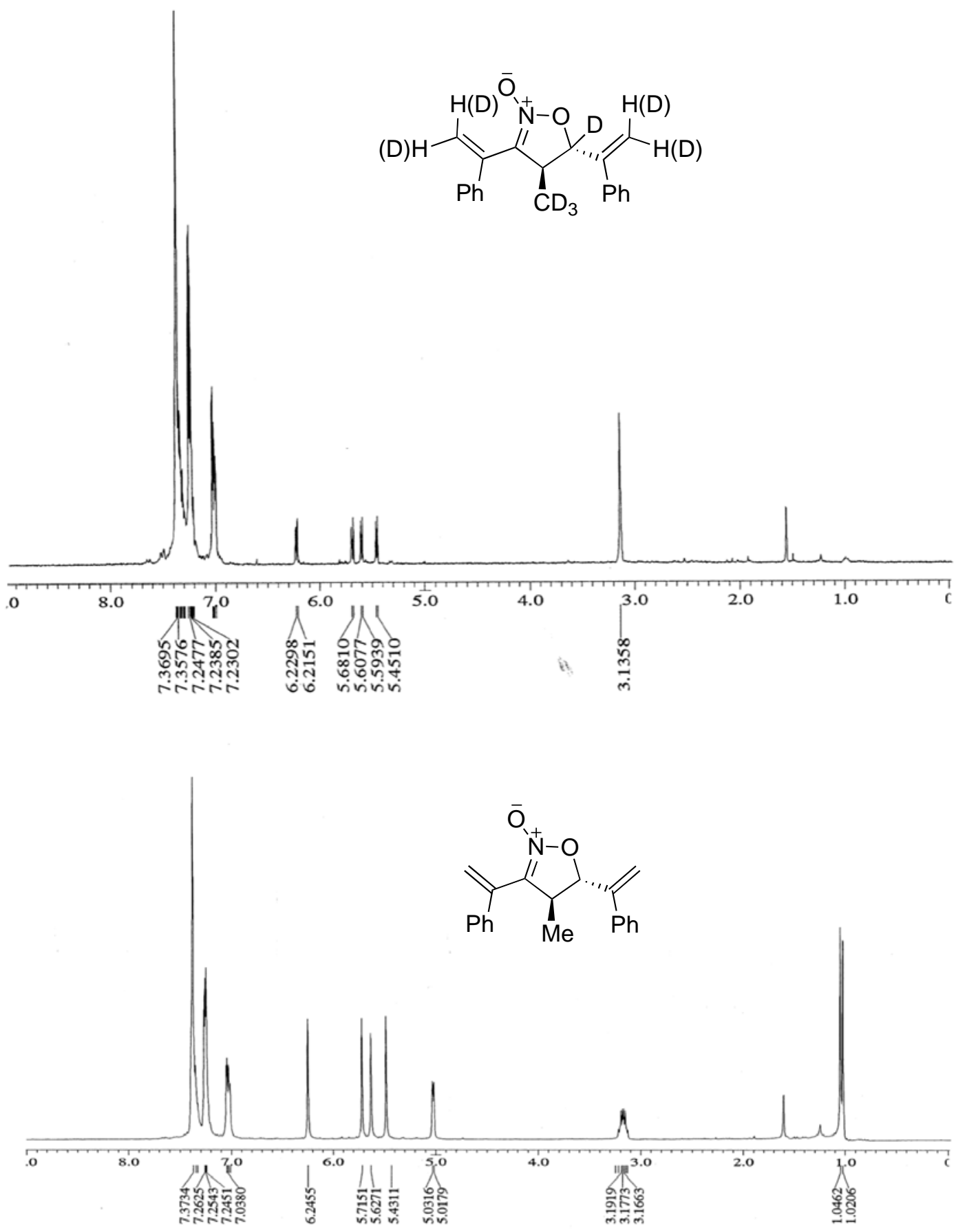

Representative Procedure for synthesis of 1,2,3-Triazole-Borane complexes:

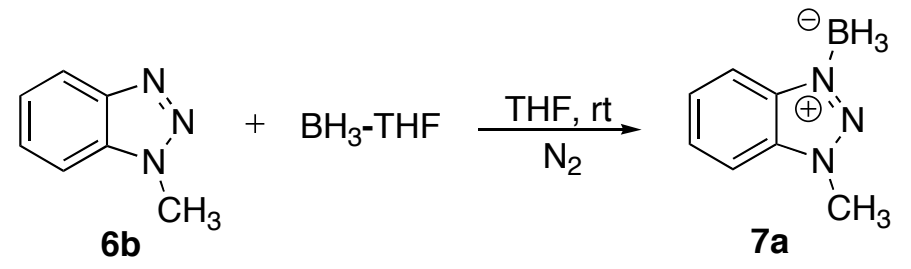


The N-1 methyl benzotriazole $6 \mathbf{b}(1.331 \mathrm{~g}, 10 \mathrm{mmol}, 1$ equiv $)$ was dissolved in dry THF (10 mL, $1.0 \mathrm{M}$ ) in a $50 \mathrm{ml}$ round bottom flask under $\mathrm{N}_{2}$ atmosphere. To this solution was added $\mathrm{BH}_{3}-\mathrm{THF}$ (11 mL, 1.0 $\mathrm{M}$ in THF, 1.1 equiv) drop wise by a syringe. The resulting solution was stirred at room temperature and checked by TLC. A white precipitate was formed in about $10 \mathrm{~min}$. After the completion of the reaction, 7a $(1.470 \mathrm{~g}, 10 \mathrm{mmol}$, yield: $99 \%)$ was obtained by filtration as white solid.<smiles>CC(C)(C)OC(=O)n1nnc2ccccc21</smiles>

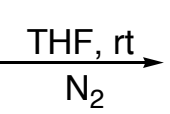

$6 d$<smiles></smiles>

$7 b$

The N-1 phenyl benzotriazole 6d (1.952 g, $10 \mathrm{mmol}, 1$ equiv) was dissolved in dry THF (10 mL, $1.0 \mathrm{M}$ ) in a $50 \mathrm{~mL}$ round bottom flask under $\mathrm{N}_{2}$ atmosphere. To this solution was added $\mathrm{BH}_{3}$ THF (11ml, 1.0 M in THF, 1.1 equiv) drop wise by a syringe. The resulting solution was stirred at room temperature and checked by TLC. When the reaction was completed, the resulting solution was concentrated and then added dry hexanes $(10 \mathrm{~mL})$, A white precipitate was formed immediately. 7b (2.090 g, $10 \mathrm{mmol}$, yield: 99\%) was obtained by filtration as white solid.

\section{$\underline{\text { Representative Procedure for Reductive Amination of Aldehydes }}$}<smiles>Nc1ccc(O)cc1</smiles>

The 4-chlorobenzaldehyde 8a (147.6 mg, $1.05 \mathrm{mmol}, 1.05$ equiv) and aniline 9a (93.13 $\mathrm{mg}, 1$ mmol, 1 equiv) were dissolved in DCE ( $4 \mathrm{~mL}, 0.25 \mathrm{M})$. To this solution was added $7 \mathbf{b}(83.6 \mathrm{mg}$, $0.4 \mathrm{mmol}, 0.4$ equiv) at room temperature. The resulting mixture was then stirred and checked by TLC. After the completion of the reaction, the mixture was quenched with water $(10 \mathrm{~mL})$, concentrated and extracted with ethyl acetate $(10 \mathrm{~mL} \times 3)$. The combined organic layer was washed with brine and dried over with anhydrous $\mathrm{Na}_{2} \mathrm{SO}_{4}$. The solvent was removed under reduced pressure to give a residue. The residue was purified by flash silica gel chromatography to obtain 10a (218.0 mg, $1 \mathrm{mmol}$, yield: 99\%) as colorless oil.

\section{Representative Procedure for Reductive Amination of Ketones}




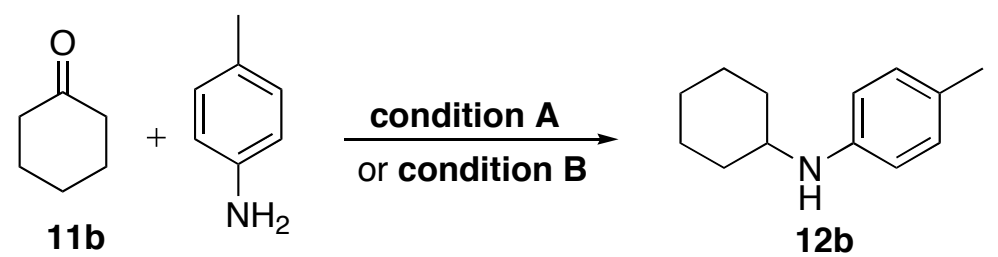

Condition A: The cyclohexanone 11b (127.6 mg, $1.3 \mathrm{mmol}, 1.3$ equiv), $p$-toluidine (107.2 $\mathrm{mg}, 1$ mmol, 1 equiv) and $\mathrm{AcOH}$ (18 mg, $0.3 \mathrm{mmol}, 0.3$ equiv) were dissolved in DCE (4 mL, $0.25 \mathrm{M})$. To this solution was added the $7 \mathbf{a}(117.6 \mathrm{mg}, 0.8 \mathrm{mmol}, 0.8$ equiv) at room temperature. The resulting mixture was then stirred and checked by TLC. After the completion of the reaction, the mixture was quenched with water $(10 \mathrm{~mL})$, concentrated and extracted with ethyl acetate $(10 \mathrm{~mL}$ $x 3$ ). The combined organic layer was washed with brine and dried over with anhydrous $\mathrm{Na}_{2} \mathrm{SO}_{4}$. The solvent was removed under reduced pressure to give a residue. The residue was purified by flash silica gel chromatography to obtain $\mathbf{1 2 b}$ (189.1 $\mathrm{mg}, 1 \mathrm{mmol}$, yield: $99 \%)$ as white solid.

Condition B: The cyclohexanone 11b (127.6 mg, $1.3 \mathrm{mmol}, 1.3$ equiv), $p$-toluidine (107.2 $\mathrm{mg}, 1$ mmol, 1 equiv) were dissolved in DCE ( $4 \mathrm{~mL}, 0.25 \mathrm{M})$. To this solution was added the $7 \mathbf{a}(88.2$ $\mathrm{mg}, 0.6 \mathrm{mmol}, 0.6$ equiv) at room temperature. The resulting mixture was then stirred at $60^{\circ} \mathrm{C}$ and checked by TLC. After the reaction was completed, the mixture was cooled down and quenched with water $(10 \mathrm{~mL})$, concentrated and extracted with ethyl acetate $(10 \mathrm{~mL} \times 3)$. The combined organic layer was washed with brine and dried over with anhydrous $\mathrm{Na}_{2} \mathrm{SO}_{4}$. The solvent was removed under reduced pressure to give a residue, the residue was purified by flash silica gel chromatography to obtain $\mathbf{1 2 b}$ (189.1 $\mathrm{mg}, 1 \mathrm{mmol}$, yield: $99 \%$ ) as white solid.

\section{Representative Procedure for Reductive Amination of Amino Acid}

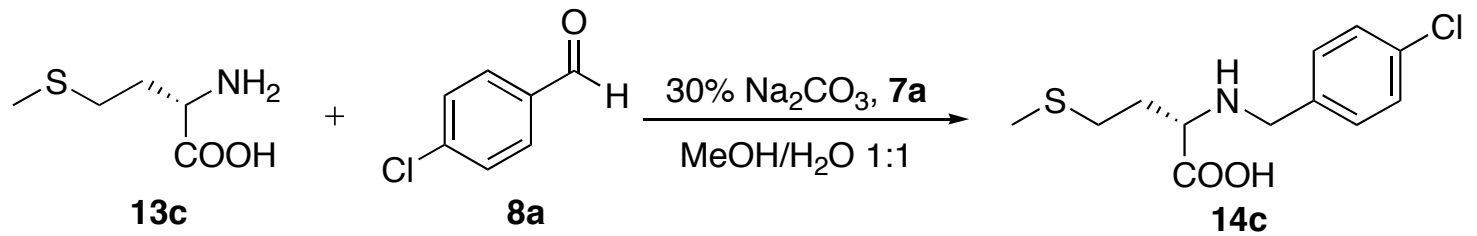

The methionine 13c (149.2 mg, $1 \mathrm{mmol}, 1$ equiv) and $\mathrm{Na}_{2} \mathrm{CO}_{3}(31.8 \mathrm{mg}, 0.3 \mathrm{mmol}, 0.3$ equiv) were dissolved in water $(3 \mathrm{~mL})$. To this solution was added 4-chlorobenzaldehyde $8 \mathbf{8 a}(210.8 \mathrm{mg}$, $1.5 \mathrm{mmol}, 1.5$ equiv), methanol $(2 \mathrm{~mL})$ and $7 \mathrm{a}(220.5 \mathrm{mg}, 1.5 \mathrm{mmol}, 1.5$ equiv) successively at room temperature. The resulting mixture was then stirred and checked by TLC. After the completion of the reaction, the resulting mixture was filtered to remove the indissoluble solid (6b). The solvent of the filtered solution was removed to get a residue. The residue was then diluted with $\mathrm{CH}_{2} \mathrm{Cl}_{2}(5 \mathrm{~mL})$ and water $(5 \mathrm{~mL}) .0 .1 \mathrm{M} \mathrm{HCl}$ solution was added to the solution until $\mathrm{pH}=7$, then a white solid was obtained by filtration of the mixture. 14c was purified by recrystallization $\left(\mathrm{MeOH} / \mathrm{H}_{2} \mathrm{O}=3: 1\right)$ from the white solid as white crystal $(232 \mathrm{mg}, 0.85 \mathrm{mmol}$, yield: $85 \%)$. 


\section{Compounds Characterization:}<smiles>C=C(c1ccccc1)C1O[N+]([O-])=C(c2ccccc2)C1C</smiles>

$3 a$

4-Methyl-3, 5-bis(1-phenylvinyl)isoxazoline- $N$-oxide 3a

Purified by flash chromatography (hexane-EtOAc, v/v = 7/1) as colorless oil (yield: $88 \%) ;{ }^{1} \mathrm{H}$ NMR $\left(270 \mathrm{MHz}, \mathrm{CDCl}_{3}\right) \delta$ 7.42-7.30 (m, 5H), 7.28-7.20 (m, 3H), 7.06-6.98 (m, 2H), $6.24(\mathrm{~s}$, $1 \mathrm{H}), 5.71(\mathrm{~s}, 1 \mathrm{H}), 5.62(\mathrm{~s}, 1 \mathrm{H}), 5.48(\mathrm{~s}, 1 \mathrm{H}), 5.02(\mathrm{~d}, J=5.4 \mathrm{~Hz}, 1 \mathrm{H}), 3.21-3.12(\mathrm{~m}, 1 \mathrm{H}), 1.03(\mathrm{~d}$, $J=6.7 \mathrm{~Hz}, 3 \mathrm{H}) ;{ }^{13} \mathrm{C} \mathrm{NMR}\left(67.5 \mathrm{MHz}, \mathrm{CDCl}_{3}\right): \delta 144.9,138.2,137.8,135.7,128.8,128.5$, 128.4, 128.2, 127.5, 127.1, 121.8, 117.5, 115.4, 82.6, 45.4, 17.7; HRMS Calculated for $\mathrm{C}_{20} \mathrm{H}_{19} \mathrm{NO}_{2}[\mathrm{M}+\mathrm{H}]^{+}:$306.14940, Found: 306.14925.<smiles>C=C(c1ccccc1)C1O[N+](=O)C(C(=C)c2ccccc2)C1CC</smiles>

3b

\section{4-Ethyl-3, 5-bis(1-phenylvinyl)isoxazoline- $N$-oxide $3 b$}

Purified by flash chromatography (hexane-EtOAc, v/v =7/1) as colorless oil (yield: $76 \%$ ); ${ }^{1} \mathrm{H}$ NMR $\left(270 \mathrm{MHz}, \mathrm{CDCl}_{3}\right) \delta$ 7.38-7.34 (m, 5H), 7.25-7.20 (m, 3H), 7.00-6.96 (m, 2H), $6.25(\mathrm{~d}, J=$ $0.73 \mathrm{~Hz}, 1 \mathrm{H}), 5.72(\mathrm{~d}, J=0.76 \mathrm{~Hz}, 1 \mathrm{H}), 5.63(\mathrm{~s}, 1 \mathrm{H}), 5.44(\mathrm{~s}, 1 \mathrm{H}), 5.11(\mathrm{~d}, J=2.46 \mathrm{~Hz}, 1 \mathrm{H})$, 3.04-2.99 (m, 1H), 1.46-1.35 (m, 2H), $0.75(\mathrm{t}, J=7.43 \mathrm{~Hz}, 3 \mathrm{H}) ;{ }^{13} \mathrm{C}$ NMR $\left(67.5 \mathrm{MHz}, \mathrm{CDCl}_{3}\right): \delta$ 145.8, 138.3, 137.9, 135.9, 128.8, 128.4, 128.1, 127.5, 127.3, 121.7, 116.3, 115.3, 80.0, 51.3, 24.9, 9.97; HRMS Calculated for $\mathrm{C}_{21} \mathrm{H}_{21} \mathrm{NO}_{2}[\mathrm{M}+\mathrm{H}]^{+}: 320.16503$, Found: 320.16480 .<smiles>C=C(c1ccccc1)C1C(=C)[N+](=O)O[C@H]1C(=C)c1ccccc1</smiles>

3c

\section{4-Propyl-3, 5-bis(1-phenylvinyl)isoxazoline- $N$-oxide 3c}

Purified by flash chromatography (hexane-EtOAc, v/v =7/1) as colorless oil (yield: $71 \%$ ); ${ }^{1} \mathrm{H}$ $\operatorname{NMR}\left(270 \mathrm{MHz}, \mathrm{CDCl}_{3}\right) \delta$ 7.41-7.28 (m, 5H), 7.27-7.18 (m, 3H), 6.99-6.95 (m, 2H), $6.27(\mathrm{~d}, J=$ $0.76 \mathrm{~Hz}, 1 \mathrm{H}), 5.71(\mathrm{~d}, J=0.73 \mathrm{~Hz}, 1 \mathrm{H}), 5.63(\mathrm{~s}, 1 \mathrm{H}), 5.43(\mathrm{~s}, 1 \mathrm{H}), 5.09(\mathrm{~d}, J=2.48 \mathrm{~Hz}, 1 \mathrm{H})$, $3.06-3.01(\mathrm{~m}, 1 \mathrm{H}), 1.50-0.81(\mathrm{~m}, 4 \mathrm{H}), 0.56(\mathrm{t}, J=7.18 \mathrm{~Hz}, 3 \mathrm{H}) ;{ }^{13} \mathrm{C} \mathrm{NMR}\left(67.5 \mathrm{MHz}, \mathrm{CDCl}_{3}\right): \delta$ 145.6, 138.1, 137.7, 135.7, 128.6, 128.2, 128.0, 127.3, 127.1, 121.5, 116.5, 115.1, 80.2, 49.5, 33.7, 18.6, 13.2; HRMS Calculated for $\mathrm{C}_{22} \mathrm{H}_{23} \mathrm{NO}_{2}[\mathrm{M}+\mathrm{H}]^{+}:$334.18070, Found: 334.18049. 
<smiles>C=C(C1=[N+]([O-])O[C@H](C(=C)c2ccccc2)[C@H]1C)c1ccccc1</smiles>

3d

\section{4-(Phenylethyl)-3, 5-bis(1-phenylvinyl)isoxazoline- $N$-oxide 3d}

Purified by flash chromatography (hexane-EtOAc, v/v $=7 / 1$ ) as colorless oil (yield: $65 \%$ ); ${ }^{1} \mathrm{H}$ NMR (600 MHz, $\left.\mathrm{CDCl}_{3}\right) \delta$ 7.39-7.34 (m, 5H), 7.26-7.19 (m, 4H), 7.13-7.11 (m, 2H), 6.94-6.92 $(\mathrm{m}, 2 \mathrm{H}), 6.75-6.73(\mathrm{~m}, 2 \mathrm{H}), 6.25(\mathrm{~s}, 1 \mathrm{H}), 5.71(\mathrm{~s}, 1 \mathrm{H}), 5.62(\mathrm{~s}, 1 \mathrm{H}), 5.48(\mathrm{~s}, 1 \mathrm{H}), 5.02(\mathrm{~d}, J=5.4$ $\mathrm{Hz}, 1 \mathrm{H}), 3.21-3.12(\mathrm{~m}, 1 \mathrm{H}), 2.53-2.48(\mathrm{~m}, 1 \mathrm{H}), 2.38-2.32(\mathrm{~m}, 1 \mathrm{H}), 1.82-1.75(\mathrm{~m}, 1 \mathrm{H}), 1.71-1.65$ $(\mathrm{m}, 1 \mathrm{H}) ;{ }^{13} \mathrm{C}$ NMR $\left(150 \mathrm{MHz}, \mathrm{CDCl}_{3}\right): \delta 145.8,140.0,138.2,137.9,135.7,128.8,128.37$, 128.35, 128.1, 128.0, 127.4, 127.3, 126.0, 121.7, 116.2, 115.6, 80.5, 49.3, 33.2, 31.6; HRMS Calculated for $\mathrm{C}_{27} \mathrm{H}_{25} \mathrm{NO}_{2}[\mathrm{M}+\mathrm{H}]^{+}$: 396.19635, Found: 396.19625.<smiles>[CH]C1C(C(=C)c2ccc(C)cc2)=[N+]([O-])O[C@H]1C(=C)c1ccc(C)cc1</smiles>

$3 e$

\section{4-Methyl-3, 5-bis(1-p-tolylvinyl)isoxazoline- $\mathrm{N}$-oxide $3 \mathrm{e}$}

Purified by flash chromatography (hexane-EtOAc, v/v $=7 / 1$ ) as colorless oil (yield: $83 \%$ ); ${ }^{1} \mathrm{H}$ NMR (270 MHz, $\left.\mathrm{CDCl}_{3}\right) \delta$ 7.29-7.25 (m, 2H), 7.19-7.16 (m, 2H), 7.07-7.04 (m, 2H), 6.95-6.92 $(\mathrm{m}, 2 \mathrm{H}), 6.18(\mathrm{~d}, J=0.73 \mathrm{~Hz}, 1 \mathrm{H}), 5.69(\mathrm{~d}, J=0.76 \mathrm{~Hz}, 1 \mathrm{H}), 5.58(\mathrm{~s}, 1 \mathrm{H}), 5.44(\mathrm{~s}, 1 \mathrm{H}), 5.01(\mathrm{~d}, J$ $=3.7 \mathrm{~Hz}, 1 \mathrm{H}), 3.23-3.13(\mathrm{~m}, 1 \mathrm{H}), 2.35(\mathrm{~s}, 3 \mathrm{H}), 2.31(\mathrm{~s}, 3 \mathrm{H}), 1.03(\mathrm{~d}, J=6.91 \mathrm{~Hz}, 3 \mathrm{H}) ;{ }^{13} \mathrm{C} \mathrm{NMR}$ $\left(67.5 \mathrm{MHz}, \mathrm{CDCl}_{3}\right): \delta 144.7,138.3,138.1,135.5,135.3,134.8,129.5,129.2,127.4,126.9$, 121.3, 117.8, 114.4, 82.4, 45.6, 21.2, 17.7; HRMS Calculated for $\mathrm{C}_{22} \mathrm{H}_{23} \mathrm{NO}_{2}[\mathrm{M}+\mathrm{H}]^{+}$: 334.18016, Found: 334.17992 .<smiles>C=C(C(=C)C1O[N+](=O)C(C(=C)c2ccc(C)cc2)C1C)c1ccc(C)cc1</smiles>

\section{4-(Phenylethyl)-3, 5-bis(1-p-tolylvinyl)isoxazoline- $N$-oxide 3f}

Purified by flash chromatography (hexane-EtOAc, v/v $=6 / 1$ ) as colorless oil (yield: $66 \%$ ); ${ }^{1} \mathrm{H}$ NMR (270 MHz, $\left.\mathrm{CDCl}_{3}\right) \delta$ 7.25-7.17 (m, 4H), 7.11-7.07 (m, 3H), 7.00-6.97 (m, 2H), 6.83-6.79 $(\mathrm{m}, 2 \mathrm{H}), 6.75-6.69(\mathrm{~m}, 2 \mathrm{H}), 6.20(\mathrm{~d}, J=0.76 \mathrm{~Hz}, 1 \mathrm{H}), 5.67(\mathrm{~d}, J=0.73 \mathrm{~Hz}, 1 \mathrm{H}), 5.59(\mathrm{~s}, 1 \mathrm{H})$, $5.39(\mathrm{~s}, 1 \mathrm{H}), 5.14(\mathrm{~d}, J=2.21 \mathrm{~Hz}, 1 \mathrm{H}), 3.11-3.07(\mathrm{~m}, 1 \mathrm{H}), 2.55-2.45(\mathrm{~m}, 1 \mathrm{H}), 2.36(\mathrm{~s}, 3 \mathrm{H}), 2.31$ (s, 3H), 1.82-1.59 (m, 2H); ${ }^{13} \mathrm{C}$ NMR $\left(67.5 \mathrm{MHz}, \mathrm{CDCl}_{3}\right): \delta 145.7,140.2,138.3,138.0,135.6$, 
135.4, 135.0, 129.5, 129.1, 128.4, 128.2, 127.4, 127.3, 125.9, 121.3, 116.5, 114.8, 80.5, 49.5, 33.3, 31.7, 21.3; HRMS Calculated for $\mathrm{C}_{29} \mathrm{H}_{29} \mathrm{NO}_{2}[\mathrm{M}+\mathrm{H}]^{+}$: 424.22711, Found: 424.22673.<smiles>C=C(C1=[N+]([O-])O[C@@H](C(=C)c2ccc(Cl)cc2)C1C)c1ccc(Cl)cc1</smiles>

$3 g$

\section{4-Methyl-3, 5-bis(1-p-chlorophenylvinyl)isoxazoline- $N$-oxide $3 g$}

Purified by flash chromatography (hexane-EtOAc, v/v =6/1) as colorless oil (yield: $77 \%$ ); ${ }^{1} \mathrm{H}$ NMR $\left(270 \mathrm{MHz}, \mathrm{CDCl}_{3}\right) \delta$ 7.38-7.30 (m, 3H), 7.25-7.22 (m, 3H), 6.97-6.93 (d, J = 8.7 Hz 2H), $6.15(\mathrm{~s}, 1 \mathrm{H}), 5.69(\mathrm{~s}, 1 \mathrm{H}), 5.61(\mathrm{~s}, 1 \mathrm{H}), 5.46(\mathrm{~s}, 1 \mathrm{H}), 4.98(\mathrm{~d}, J=4.13 \mathrm{~Hz}, 1 \mathrm{H}), 3.16-3.07(\mathrm{~m}$, $1 \mathrm{H}), 1.06(\mathrm{~d}, J=6.94 \mathrm{~Hz}, 3 \mathrm{H}) ;{ }^{13} \mathrm{C}$ NMR $\left(67.5 \mathrm{MHz}, \mathrm{CDCl}_{3}\right): \delta 143.7,136.3,136.0,134.7$, 134.5, 134.3, 129.1, 128.8, 128.7, 128.5, 122.3, 117.1, 116.4, 82.6, 45.3, 17.7; HRMS Calculated for $\mathrm{C}_{20} \mathrm{H}_{17} \mathrm{Cl}_{2} \mathrm{NO}_{2}[\mathrm{M}+\mathrm{H}]^{+}: 374.07146$ Found: 374.07137<smiles>C=C(C1=[N+]([O-])O[C@@H](C(=C)c2ccc(Cl)cc2)C1CC)c1ccc(Cl)cc1</smiles>

$3 \mathrm{~h}$

\section{4-Ethyl-3, 5-bis(1-p-chlorophenylvinyl)isoxazoline- $\mathrm{N}$-oxide $3 \mathrm{~h}$}

Purified by flash chromatography (hexane-EtOAc, v/v =6/1) as colorless oil (yield: $58 \%$ ); ${ }^{1} \mathrm{H}$ NMR $\left(600 \mathrm{MHz}, \mathrm{CDCl}_{3}\right) \delta 7.36(\mathrm{~d}, J=8.4 \mathrm{~Hz}, 2 \mathrm{H}), 7.31(\mathrm{~d}, J=8.4 \mathrm{~Hz}, 2 \mathrm{H}), 7.22(\mathrm{~d}, J=9.0$ $\mathrm{Hz}, 2 \mathrm{H}), 6.90$ (d, J = 8.4 Hz, 2H), $6.17(\mathrm{~s}, 1 \mathrm{H}), 5.69$ (s, 1H), $5.61(\mathrm{~s}, 1 \mathrm{H}), 5.42(\mathrm{~s}, 1 \mathrm{H}), 5.07$ (d, $J$ $=3.0 \mathrm{~Hz}, 1 \mathrm{H}), 2.98-2.95(\mathrm{~m}, 1 \mathrm{H}), 1.46-1.43(\mathrm{~m}, 2 \mathrm{H}), 0.79(\mathrm{t}, J=7.2 \mathrm{~Hz}, 3 \mathrm{H}) ;{ }^{13} \mathrm{C} \mathrm{NMR}(150$ $\left.\mathrm{MHz}, \mathrm{CDCl}_{3}\right): \delta 145.0,136.7,136.3,135.1,134.7,134.5,129.2,128.87,128.85,128.8,122.3$, 116.4, 115.8, 81.5, 58.0, 25.2, 11.1; HRMS Calculated for $\mathrm{C}_{21} \mathrm{H}_{19} \mathrm{Cl}_{2} \mathrm{NO}_{2}[\mathrm{M}+\mathrm{H}]^{+}:$388.08656, Found: 388.08666.<smiles>[M]C1C(C(=C)c2ccc3ccccc3c2)=[N+]([O-])O[C@H]1C(=C)c1ccc2ccccc2c1</smiles>

$3 \mathbf{i}$ 


\section{4-Methyl-3, 5-bis(1-(2-naphthyl)vinyl)isoxazoline- $N$-oxide $3 i$}

Purified by flash chromatography (hexane-EtOAc, v/v $=5 / 1$ ) as colorless oil (yield: $75 \%$ ); ${ }^{1} \mathrm{H}$ NMR $\left(600 \mathrm{MHz}, \mathrm{CDCl}_{3}\right) \delta$ 7.87-7.83 (m, 4H), $7.22(\mathrm{~d}, J=7.8 \mathrm{~Hz}, 1 \mathrm{H}), 7.61(\mathrm{~d}, J=7.4 \mathrm{~Hz}, 1 \mathrm{H})$, $7.58(\mathrm{dd}, J=1.8 \mathrm{~Hz}, J=7.4 \mathrm{~Hz}, 1 \mathrm{H}), 7.52-7.48(\mathrm{~m}, 3 \mathrm{H}), 7.43-7.36(\mathrm{~m}, 3 \mathrm{H}), 7.10$ (dd, $J=1.8 \mathrm{~Hz}$, $J=7.4 \mathrm{~Hz}, 1 \mathrm{H}), 6.32(\mathrm{~s}, 1 \mathrm{H}), 5.82(\mathrm{~s}, 1 \mathrm{H}), 5.75(\mathrm{~s}, 1 \mathrm{H}), 5.64(\mathrm{~s}, 1 \mathrm{H}), 5.16(\mathrm{~d}, J=3.6 \mathrm{~Hz}, 1 \mathrm{H})$, 3,30-3,28 (m, $1 \mathrm{H}), 1.07(\mathrm{~d}, J=6.6 \mathrm{~Hz}, 1 \mathrm{H}) ;{ }^{13} \mathrm{C} \mathrm{NMR}\left(150 \mathrm{MHz}, \mathrm{CDCl}_{3}\right): \delta 144.9,135.5,135.4$, 135.1, 133.2, 133.0, 132.9, 132.7, 128.5, 128.1, 128.0, 127.9, 127.6, 126.5, 126.44, 126.41, 126.3, 126.2, 125.9, 125.1, 124.9, 122.0, 117.5, 115.9, 82.6, 45.4, 17.6; HRMS Calculated for $\mathrm{C}_{28} \mathrm{H}_{23} \mathrm{NO}_{2}[\mathrm{M}+\mathrm{H}]^{+}:$406.18016, Found: 406.18031.

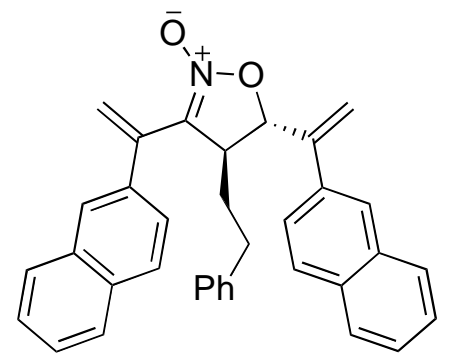

3j

\section{4-(Phenylethyl)-3, 5-bis(1-(2-naphthyl)vinyl)isoxazoline- $N$-oxide 3j}

Purified by flash chromatography (hexane-EtOAc, v/v $=5 / 1$ ) as colorless oil (yield: $61 \%$ ); ${ }^{1} \mathrm{H}$ NMR $\left(600 \mathrm{MHz}, \mathrm{CDCl}_{3}\right) \delta$ 7.87-7.81 (m, 3H), $7.73(\mathrm{~s}, 1 \mathrm{H}), 7.70(\mathrm{~d}, J=7.8 \mathrm{~Hz}, 1 \mathrm{H}), 7.54-7.47$ (m, 4H), 7.42-7.39 (m, 1H), 7.37-7.33 (m, 2H), 7.21 (s, 1H), $6.92(\mathrm{dd}, J=1.8 \mathrm{~Hz}, J=7.4 \mathrm{~Hz}$, $1 \mathrm{H}), 6.82(\mathrm{t}, J=7.8 \mathrm{~Hz}, 1 \mathrm{H}), 6.70(\mathrm{t}, J=7.8 \mathrm{~Hz}, 1 \mathrm{H}), 6.45(\mathrm{~d}, J=7.2 \mathrm{~Hz}, 1 \mathrm{H}), 6.37(\mathrm{~s}, 1 \mathrm{H}), 5.77$ $(\mathrm{s}, 1 \mathrm{H}), 5.73(\mathrm{~s}, 1 \mathrm{H}), 5.55(\mathrm{~s}, 1 \mathrm{H}), 5.26(\mathrm{~d}, J=3.0 \mathrm{~Hz}, 1 \mathrm{H}), 3.14-3.11(\mathrm{~m}, 1 \mathrm{H}), 2.51-2.46(\mathrm{~m}, 1 \mathrm{H})$,

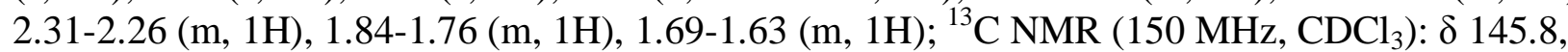
139.3, 135.5, 135.4, 135.3, 133.2, 133.0, 132.8, 133.7, 128.5, 128.1, 128.0, 127.6, 127. 4, 126.6, 126.5, 126.4, 126.2, 125.7, 125.18, 125.16, 122.06, 116.37, 80.7, 48.9, 32.9, 31.3; HRMS Calculated for $\mathrm{C}_{35} \mathrm{H}_{29} \mathrm{NO}_{2}[\mathrm{M}+\mathrm{H}]^{+}$: 496.22711, Found: 496.22691.

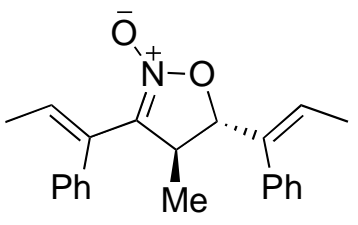

3k

\section{4-Methyl-3, 5-bis((E)-1-phenylprop-1-enyl)isoxazoline- $N$-oxide $3 k$}

Purified by flash chromatography (hexane-EtOAc, v/v $=7 / 1$ ) as colorless oil (yield: 75\%), colorless solid formed several days later. m.p. $152-154{ }^{\circ} \mathrm{C} ;{ }^{1} \mathrm{H}$ NMR $\left(600 \mathrm{MHz}, \mathrm{CDCl}_{3}\right) \delta 7.40-$ $7.37(\mathrm{~m}, 2 \mathrm{H}), 7.34-7.31(\mathrm{~m}, 1 \mathrm{H}), 7.25-7.22(\mathrm{~m}, 3 \mathrm{H}), 7.20-7.18(\mathrm{~m}, 2 \mathrm{H}), 6.99(\mathrm{q}, J=7.2 \mathrm{~Hz}, 1 \mathrm{H})$, 6.72-6.71 (m, 2H), 5.95-5.91 (q, $J=6.6 \mathrm{~Hz}), 4.63(\mathrm{~d}, J=3.6 \mathrm{~Hz}, 1 \mathrm{H}), 2.83-2.81(\mathrm{~m}, 1 \mathrm{H}), 1.63(\mathrm{t}$, $J=7.2 \mathrm{~Hz}, 3 \mathrm{H}), 1.57(\mathrm{t}, J=7.2 \mathrm{~Hz}, 3 \mathrm{H}), 0.89(\mathrm{~d}, J=6.6 \mathrm{~Hz}, 3 \mathrm{H}) ;{ }^{13} \mathrm{C} \mathrm{NMR}\left(150 \mathrm{MHz}, \mathrm{CDCl}_{3}\right)$ : $\delta 138.3,136.3,136.2,132.4,129.59,129.56,128.9,128.7,128.4,127.8,127.6,127.5,118.9$, 85.9, 44.7, 18.0, 15.4,14.6; HRMS Calculated for $\mathrm{C}_{22} \mathrm{H}_{23} \mathrm{NO}_{2}[\mathrm{M}+\mathrm{H}]^{+}: 334.18016$, Found: 334.18013 . 


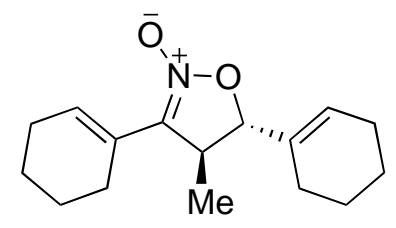

3!

\section{4-Methyl-3, 5-dicyclohexenylisoxazoline- $N$-oxide 31}

Purified by flash chromatography (hexane-EtOAc, v/v 7/1) as pale yellow solid (yield 87\%), m.p. $126-128{ }^{\circ} \mathrm{C} ;{ }^{1} \mathrm{H}$ NMR $\left(600 \mathrm{MHz}, \mathrm{CDCl}_{3}\right): \delta 6.43-6.41(\mathrm{~m}, 1 \mathrm{H}), 5.75(\mathrm{~s}, 1 \mathrm{H}), 4.66(\mathrm{~d}, J=3.6$ $\mathrm{Hz}, 1 \mathrm{H}), 3.28-3.26(\mathrm{~m}, 1 \mathrm{H}), 2.54-2.50(\mathrm{~m}, 1 \mathrm{H}), 2.28-2.19(\mathrm{~m}, 3 \mathrm{H}), 2.10-2.02(\mathrm{~m}, 3 \mathrm{H}), 1.92-1.88$ $(\mathrm{m}, 1 \mathrm{H}), 1.75-1.52(\mathrm{~m}, 8 \mathrm{H}), 1.31(\mathrm{~d}, J=6.6 \mathrm{~Hz}, 3 \mathrm{H}) ;{ }^{13} \mathrm{C} \mathrm{NMR}\left(150 \mathrm{MHz}, \mathrm{CDCl}_{3}\right): \delta 134.4$, 131.7, 125.8, 125.1, 120.1, 85.5, 43.3, 25.8, 25.5, 24.8, 22.8, 22.3, 22.12, 22.1, 21.4, 18.2; HRMS Calculated for $\mathrm{C}_{16} \mathrm{H}_{23} \mathrm{NO}_{2}[\mathrm{M}+\mathrm{H}]^{+}:$262.18070, Found: 262.18030.

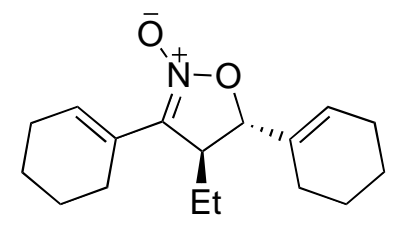

\section{$3 m$}

\section{4-Ethyl-3, 5-dicyclohexenylisoxazoline- $\mathrm{N}$-oxide $3 \mathrm{~m}$}

Purified by flash chromatography (hexane-EtOAc, v/v 7/1) as pale yellow solid (yield 80\%), m.p. $115-117{ }^{\circ} \mathrm{C} ;{ }^{1} \mathrm{H}$ NMR $\left(270 \mathrm{MHz}, \mathrm{CDCl}_{3}\right): \delta 6.41-6.40(\mathrm{~m}, 1 \mathrm{H}), 5.75(\mathrm{~s}, 1 \mathrm{H}), 4.45(\mathrm{~d}, J=2.5$ $\mathrm{Hz}, 1 \mathrm{H}), 3.07-3.05(\mathrm{~m}, 1 \mathrm{H}), 2.51-2.44(\mathrm{~m}, 1 \mathrm{H}), 2.27-2.15(\mathrm{~m}, 3 \mathrm{H}), 2.08-1.95(\mathrm{~m}, 3 \mathrm{H}), 1.91-1.77$ $(\mathrm{m}, 1 \mathrm{H}), 1.71-1.48(\mathrm{~m}, 10 \mathrm{H}), 0.95(\mathrm{t}, J=7.4 \mathrm{~Hz}, 3 \mathrm{H}) ;{ }^{13} \mathrm{C} \mathrm{NMR}\left(67.5 \mathrm{MHz}, \mathrm{CDCl}_{3}\right): \delta 135.4$, $131.7,125.2,125.0,124.9,119.0,82.6,50.0,26.0,25.6,25.1,24.8,22.8,22.2,21.5,10.4$; HRMS Calculated for $\mathrm{C}_{17} \mathrm{H}_{25} \mathrm{NO}_{2}[\mathrm{M}+\mathrm{H}]^{+}:$276.19635, Found: 276.19597.

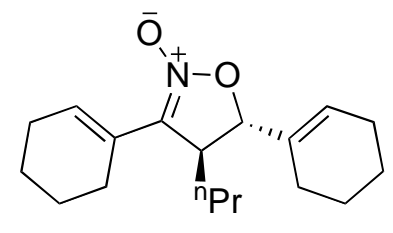

$3 n$

\section{4-Propyl-3, 5-dicyclohexenylisoxazoline- $N$-oxide $3 n$}

Purified by flash chromatography (hexane-EtOAc, v/v 7/1) as pale yellow solid (yield 74\%), m.p. $119-121{ }^{\circ} \mathrm{C} ;{ }^{1} \mathrm{H}$ NMR $\left(600 \mathrm{MHz}, \mathrm{CDCl}_{3}\right)$ : $\delta 6.44-6.42(\mathrm{~m}, 1 \mathrm{H}), 5.77(\mathrm{~s}, 1 \mathrm{H}), 4.46(\mathrm{~s}, 1 \mathrm{H})$, $3.13-3.10(\mathrm{~m}, 1 \mathrm{H}), 2.54-2.46(\mathrm{~m}, 1 \mathrm{H}), 2.28-2.16(\mathrm{~m}, 3 \mathrm{H}), 2.08-1.95(\mathrm{~m}, 3 \mathrm{H}), 1.90-1.84(\mathrm{~m}, 1 \mathrm{H})$, $1.74-1.50(\mathrm{~m}, 10 \mathrm{H}), 1.48-1.32(\mathrm{~m}, 2 \mathrm{H}), 0.94(\mathrm{t}, J=7.2 \mathrm{~Hz}, 3 \mathrm{H}) ;{ }^{13} \mathrm{C} \mathrm{NMR}\left(67.5 \mathrm{MHz}, \mathrm{CDCl}_{3}\right): \delta$ $135.4,131.8,125.2,124.9,119.2,83.1,48.5,34.2,26.0,25.6,24.8,22.8,22.4,22.2,21.5,19.4$, 13.9; HRMS Calculated for $\mathrm{C}_{18} \mathrm{H}_{27} \mathrm{NO}_{2}[\mathrm{M}+\mathrm{H}]^{+}: 290.21200$, Found: 290.21166. 


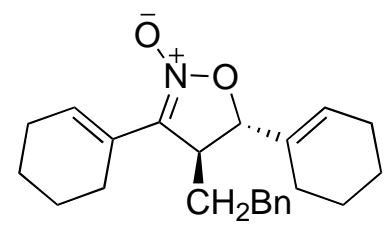

30

\section{4--(Phenylethyl)-3, 5-dicyclohexenylisoxazoline- $\mathbf{N}$-oxide 30}

Purified by flash chromatography (hexane-EtOAc, v/v 7/1) as pale yellow solid (yield 70\%), m.p. $123-125{ }^{\circ} \mathrm{C} ;{ }^{1} \mathrm{H}$ NMR $\left(270 \mathrm{MHz}, \mathrm{CDCl}_{3}\right): \delta 7.35-7.10(\mathrm{~m}, 5 \mathrm{H}), 6.27(\mathrm{~s}, 1 \mathrm{H}), 5.78(\mathrm{~s}, 1 \mathrm{H})$, $4.56(\mathrm{~s}, 1 \mathrm{H}), 3.17-3.10(\mathrm{~m}, 1 \mathrm{H}), 2.84-2.56(\mathrm{~m}, 2 \mathrm{H}), 2.51-2.38(\mathrm{~m}, 1 \mathrm{H}), 2.24-1.80(\mathrm{~m}, 9 \mathrm{H}), 1.72-$ $1.48(\mathrm{~m}, 8 \mathrm{H}) ;{ }^{13} \mathrm{C}$ NMR $\left(67.5 \mathrm{MHz}, \mathrm{CDCl}_{3}\right): \delta 140.6,135.2,131.9,128.6,128.4,126.3,125.6$, 125.1, 119.0, 83.1, 77.5, 77.1, 76.6, 47.8, 32.2, 26.0, 25.5, 24.9, 22.8, 22.4, 22.2; HRMS Calculated for $\mathrm{C}_{23} \mathrm{H}_{29} \mathrm{NO}_{2}[\mathrm{M}+\mathrm{H}]^{+}: 352.22765$, Found: 352.22747

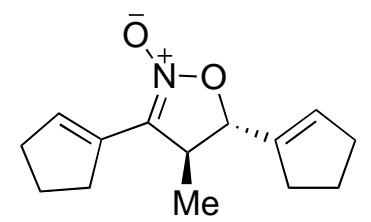

$3 p$

\section{4-Methyl-3, 5-dicyclopentenylisoxazoline- $\mathrm{N}$-oxide 3P}

Purified by flash chromatography (hexane-EtOAc, v/v 7/1) as pale yellow solid (yield 72\%), m.p.48-50 ${ }^{\circ} \mathrm{C} ;{ }^{1} \mathrm{H}$ NMR $\left(270 \mathrm{MHz}, \mathrm{CDCl}_{3}\right): \delta 6.44(\mathrm{~s}, 1 \mathrm{H}), 5.75(\mathrm{~s}, 1 \mathrm{H}), 4.66(\mathrm{~d}, J=3.7 \mathrm{~Hz}, 1 \mathrm{H})$, 3.28-3.15 (m, 1H), 2.84-2.67 (m, 1H), 2.66-2.52 (m, 1H), 2.45-2.42 (m, 2H), 2.35-2.20 (m, 4H), $1.98-1.79(\mathrm{~m}, 4 \mathrm{H}), 1.32(\mathrm{~d}, J=6.9 \mathrm{~Hz}, 3 \mathrm{H}) ;{ }^{13} \mathrm{C} \mathrm{NMR}\left(67.5 \mathrm{MHz}, \mathrm{CDCl}_{3}\right): \delta 140.5,134.7,134.6$, 129.9, 129.3, 117.6, 81.1, 43.7, 33.3, 32.7, 32.2, 30.6, 23.2, 17.8; HRMS Calculated for $\mathrm{C}_{14} \mathrm{H}_{19} \mathrm{NO}_{2}[\mathrm{M}+\mathrm{H}]^{+}:$234.14940, Found: 234.14951.

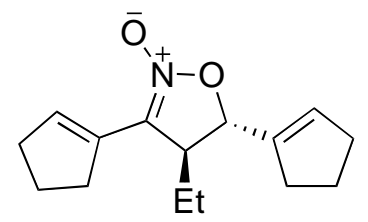

\section{$3 q$}

\section{4-Ethyl-3, 5-dicyclopentenylisoxazoline- $\boldsymbol{N}$-oxide $3 q$}

Purified by flash chromatography (hexane-EtOAc, v/v 7/1) as colerless oil (yield 65\%); ${ }^{1} \mathrm{H}$ NMR $\left(270 \mathrm{MHz}, \mathrm{CDCl}_{3}\right): \delta 6.48-6.44(\mathrm{~m}, 1 \mathrm{H}), 5.77(\mathrm{~s}, 1 \mathrm{H}), 4.82(\mathrm{~s}, 1 \mathrm{H}), 3.07-3.05(\mathrm{~m}, 1 \mathrm{H}), 2.83-2.58$ (m, 1H), 2.53-2.45 (m, 2H), 2.39-2.28 (m, 4H), 1.99-1.87 (m, 5H), 1.78-1.68 (m, 2H), 0.99 (t, $J$ $=7.4 \mathrm{~Hz}, 3 \mathrm{H}) ;{ }^{13} \mathrm{C} \mathrm{NMR}\left(67.5 \mathrm{MHz}, \mathrm{CDCl}_{3}\right): \delta 141.5,134.5,130.0,128.5,116.2,79.0,50.3$, $33.3,32.7,32.2$, 30.6, 24.6, 23.2, 10.5; HRMS Calculated for $\mathrm{C}_{15} \mathrm{H}_{21} \mathrm{NO}_{2}[\mathrm{M}+\mathrm{H}]^{+}:$: 248.16451, Found: 248.16442. 


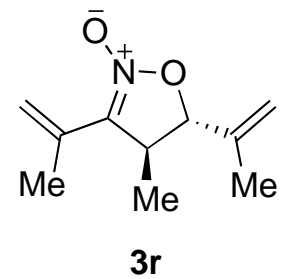

4-Methyl-3, 5-di(prop-1-en-2-yl)isoxazoline- $\mathrm{N}$-oxide $3 \mathbf{r}$

Purified by flash chromatography (hexane-EtOAc, v/v = 8/1) as colorless oil (yield: 55\%); ${ }^{1} \mathrm{H}$ NMR $\left(270 \mathrm{MHz}, \mathrm{CDCl}_{3}\right) \delta 5.55(\mathrm{~s}, 1 \mathrm{H}), 5.29(\mathrm{~s}, 1 \mathrm{H}), 5.10(\mathrm{~s}, 1 \mathrm{H}), 4.94(\mathrm{~s}, 1 \mathrm{H}), 4.45(\mathrm{~d}, J=3.94$ $\mathrm{Hz}, 1 \mathrm{H}), 3.33-3.22(\mathrm{~m}, 1 \mathrm{H}), 2.09(\mathrm{~s}, 3 \mathrm{H}), 1.77(\mathrm{~s}, 3 \mathrm{H}), 1.36(\mathrm{~d}, J=6.94 \mathrm{~Hz} \mathrm{3H}) ;{ }^{13} \mathrm{C}$ NMR $(67.5$ $\left.\mathrm{MHz}, \mathrm{CDCl}_{3}\right): \delta 141.1,131.0,119.5,118.9,113.5,84.2,43.9,20.5,18.2,16.9 ; \mathrm{HRMS}$ Calculated for $\mathrm{C}_{10} \mathrm{H}_{15} \mathrm{NO}_{2}[\mathrm{M}+\mathrm{H}]^{+}:$182.11756, Found: 182.11743 .<smiles>C=C(C1=NOC(C(=C)c2ccccc2)C1C)c1ccccc1</smiles>

$5 a$

\section{4-Methyl-3, 5-bis(1-phenylvinyl)isoxazoline 5a}

Purified by flash chromatography (hexane-EtOAc, v/v =10/1) as pale yellow oil (yield: $81 \%$ ); ${ }^{1} \mathrm{H}$ NMR $\left(270 \mathrm{MHz}, \mathrm{CDCl}_{3}\right) \delta$ 7.44-7.29 (m, 10H), $5.56(\mathrm{~s}, 1 \mathrm{H}), 5.51(\mathrm{~s}, 1 \mathrm{H}), 5.46(\mathrm{~s}, 1 \mathrm{H}), 5.41$ $(\mathrm{s}, 1 \mathrm{H}), 5.21(\mathrm{~d}, J=4.97 \mathrm{~Hz}, 1 \mathrm{H}), 3.31-3.21(\mathrm{~m}, 1 \mathrm{H}), 1.28(\mathrm{~d}, J=7.18 \mathrm{~Hz}, 3 \mathrm{H}) ;{ }^{13} \mathrm{C} \mathrm{NMR}(67.5$ $\left.\mathrm{MHz} \mathrm{CDCl}_{3}\right): \delta 161.7,145.7,139.1,138.3,138.2,128.7,128.3,128.2,128.1,127.1,120.3$, 114.2, 89.75, 48.5, 18.2; HRMS Calculated for $\mathrm{C}_{20} \mathrm{H}_{19} \mathrm{NO}[\mathrm{M}+\mathrm{H}]^{+}: 290.15449$, Found: 290.15430 .<smiles>CC1C(C2=CCCCC2)=NO[C@H]1C1=CCCCC1</smiles>

$5 b$

\section{4-Methyl-3, 5-dicyclohexenylisoxazoline 5b}

Purified by flash chromatography (hexane-EtOAc, v/v = 10/1) as pale yellow solid (yield: 90\%), m.p.74-76 ${ }^{\circ} \mathrm{C} ;{ }^{1} \mathrm{H}$ NMR $\left(600 \mathrm{MHz}, \mathrm{CDCl}_{3}\right) \delta 6.04-6.03(\mathrm{~m}, 1 \mathrm{H}), 5.67(\mathrm{~s}, 1 \mathrm{H}), 4.44(\mathrm{~d}, J=4.8$ $\mathrm{Hz}, 1 \mathrm{H}), 3.21-3.18(\mathrm{~m}, 1 \mathrm{H}), 2.45-2.41(\mathrm{~m}, 1 \mathrm{H}), 2.28-2.16(\mathrm{~m}, 3 \mathrm{H}), 2.03-1.96(\mathrm{~m}, 3 \mathrm{H}), 1.80-1.77$ (m, 1H), 1.69-1.49 (m, 8H), $1.25(\mathrm{~d}, J=7.2 \mathrm{~Hz}, 3 \mathrm{H}) ;{ }^{13} \mathrm{C} \mathrm{NMR}\left(150 \mathrm{MHz}, \mathrm{CDCl}_{3}\right): \delta 161.8$, 136.0, 131.2, 128.7, 124.3, 92.7, 45.4, 25.8, 25.0, 24.9, 22.9, 22.28, 22.27, 22.1, 21.9, 19.3; HRMS Calculated for $\mathrm{C}_{16} \mathrm{H}_{23} \mathrm{NO}[\mathrm{M}+\mathrm{H}]^{+}: 246.18524$, Found: 246.18519.<smiles>C=C(c1ccccc1)c1noc(C(=C)c2ccccc2)c1C</smiles>

4-Methyl-3, 5-bis(1-phenylvinyl)isoxazole 5c Purified by flash chromatography (hexane-EtOAc, v/v =10/1) as pale yellow oil (yield: $71 \%$ ); ${ }^{1} \mathrm{H} \mathrm{NMR}\left(270 \mathrm{MHz}, \mathrm{CDCl}_{3}\right)$ $\delta$ 7.45-7.23 (m, 10H), $5.86(\mathrm{~s}, 1 \mathrm{H}), 5.78(\mathrm{~s}, 1 \mathrm{H}), 5.76(\mathrm{~s}, 1 \mathrm{H}), 5.66$ 
(s, 1H), $1.46(\mathrm{~s}, 3 \mathrm{H}) ;{ }^{13} \mathrm{C}$ NMR $\left(67.5 \mathrm{MHz}, \mathrm{CDCl}_{3}\right): \delta 165.4,164.1,138.1,137.8,137.4,128.63$, 128.61, 128.5, 128.4, 127.6, 126.9, 119.8, 119.3, 111.6, 8.78; HRMS Calculated for $\mathrm{C}_{20} \mathrm{H}_{17} \mathrm{NO}$ $[\mathrm{M}+\mathrm{H}]^{+}:$288.13884, Found: 288.13865 .<smiles>CC(C)N[C@@H](C1=CCCCC1)[C@@H](C)[C@H](O)C1=CCCCC1</smiles>

$5 d$

$\mathrm{N}$-1, 3-dicyclohexenyl-3-hydroxy-2-methylpropyl)acetamide 5d

Purified by flash chromatography (hexane-EtOAc, v/v = 2/1) as colorless oil (yield: 65\%); ${ }^{1} \mathrm{H}$ NMR $\left(600 \mathrm{MHz}, \mathrm{CDCl}_{3}\right) \delta 5.67(\mathrm{~s}, 1 \mathrm{H}), 5.44(\mathrm{~d}, J=9.6 \mathrm{~Hz}, 1 \mathrm{H}), 3.91(\mathrm{t}, J=9.6 \mathrm{~Hz}, 1 \mathrm{H}), 3.77$ $(\mathrm{d}, J=9.6 \mathrm{~Hz}, 1 \mathrm{H}), 2.10-1.97(\mathrm{~m}, 2 \mathrm{H}), 1.83-1.74(\mathrm{~m}, 1 \mathrm{H}), 1.65-1.41(\mathrm{~m}, 11 \mathrm{H}), 1.25-1.11(\mathrm{~m}$, $2 \mathrm{H}), 0.91(\mathrm{~d}, J=6.6 \mathrm{~Hz}, 3 \mathrm{H}) ;{ }^{13} \mathrm{C} \mathrm{NMR}\left(67.5 \mathrm{MHz}, \mathrm{CDCl}_{3}\right): \delta 170.0,135.9,126.0,86.8,80.4$, 64.4, 42.4, 36.7, 33.3, 25.7, 25.3, 23.7, 23.0, 22.8, 22.7, 21.8, 14.1; HRMS Calculated for $\mathrm{C}_{18} \mathrm{H}_{29} \mathrm{NO}_{2}[\mathrm{M}+\mathrm{H}]^{+}:$292.22711, Found: 292.22695.<smiles></smiles>

$7 a$

1-methyl benzotriazole borane (7a): m.p. $187.2-188.9{ }^{\circ} \mathrm{C} .{ }^{1} \mathrm{H} \mathrm{NMR}\left(600 \mathrm{MHz}, \mathrm{CDCl}_{3}\right): \delta$ 8.17-8.15 (m, 1H), 7.68-7.64 (m, 2H), 7.63-7.58 (m, 1H), 4.37 (s, 3H), 2.73-2.54 (br m, 3H). ${ }^{13} \mathrm{C}$ NMR $\left(150 \mathrm{MHz} \mathrm{CDCl}_{3}\right): \delta 139.7,134.1,129.3,127.3,118.0,110.2,35.7$. HRMS Calculated for $\mathrm{C}_{7} \mathrm{H}_{11} \mathrm{BN}_{3}[\mathrm{M}+\mathrm{H}]^{+}:$147.10769, Found: 147.10763.<smiles></smiles>

1-phenyl benzotriazole borane (7b): m.p. 91.9-92.6 ${ }^{\circ} \mathrm{C} .{ }^{1} \mathrm{H}$ NMR $\left(600 \mathrm{MHz}, \mathrm{CDCl}_{3}\right): \delta 8.31$ $(\mathrm{d}, J=8.4 \mathrm{~Hz}, 1 \mathrm{H}), 7.81-7.77(\mathrm{~m}, 3 \mathrm{H}), 7.73-7.70(\mathrm{~m}, 1 \mathrm{H}), 7.69-7.66(\mathrm{~m}, 3 \mathrm{H}), 7.64-7.62(\mathrm{~m}, 1 \mathrm{H})$, 2.88-2.65 (br m, 3H). ${ }^{13} \mathrm{C} \mathrm{NMR} \mathrm{(150} \mathrm{MHz,} \mathrm{CDCl}_{3}$ ): $\delta 140.3,135.3,133.2,130.5,130.2,127.6$, 123.6, 118.9, 118.7, 111.3. HRMS Calculated for $\mathrm{C}_{12} \mathrm{H}_{13} \mathrm{BN}_{3}[\mathrm{M}+\mathrm{H}]^{+}:$209.04728, Found: 209.04723.<smiles>Clc1ccc(CNc2ccccc2)cc1</smiles>

$N$-(4-chlorobenzyl)benzenamine (10a). 10a was purified by flash silica gel chromatography 
(Hexane-EtOAc, v/v $=30: 1)$ as colorless oil, yield: 99\%. m.p. 110.1-112.3 ${ }^{\circ} \mathrm{C} .{ }^{1} \mathrm{H}$ NMR $(600$ $\left.\mathrm{MHz}, \mathrm{CDCl}_{3}\right): \delta$ 7.36-7.32 (m, 4H), 7.24-7.21 (m, 2H), 6.80-6.77 (m, $\left.1 \mathrm{H}\right), 6.66-6.64(\mathrm{~m}, 2 \mathrm{H})$, $4.35(\mathrm{~s}, 2 \mathrm{H}), 4.09(\mathrm{br}, 1 \mathrm{H}) .{ }^{13} \mathrm{C}$ NMR $\left(150 \mathrm{MHz}, \mathrm{CDCl}_{3}\right): \delta 147.8,138.0,132.8,129.2,128.7$, 128.6, 117.7, 112.8, 47.5. HRMS Calculated for $\mathrm{C}_{13} \mathrm{H}_{13} \mathrm{ClN}[\mathrm{M}+\mathrm{H}]^{+}$: 218.07310, Found: 218.07318.<smiles>COc1ccc(CNc2ccccc2)cc1</smiles>

$\mathrm{N}$-(4-methoxybenzyl)benzenamine (10b). 10b was purified by flash silica gel chromatography (Hexane-EtOAc, v/v = 30:1) as colorless oil, yield: 99\%. m.p. 112.8-114.0 ${ }^{\circ} \mathrm{C} .{ }^{1} \mathrm{H}$ NMR $(600$ $\left.\mathrm{MHz}, \mathrm{CDCl}_{3}\right): \delta$ 7.33-7.31 (m, 2H), 7.22-7.20 (m, 2H), 6.93-6.91 (m, 2H), 6.77-6.74 (m, $\left.1 \mathrm{H}\right)$, 6.68-6.66 (m, 2H), $4.28(\mathrm{~s}, 2 \mathrm{H}), 4.03(\mathrm{br}, 1 \mathrm{H}), 3.83(\mathrm{~s}, 3 \mathrm{H}) .{ }^{13} \mathrm{C} \mathrm{NMR}\left(150 \mathrm{MHz}, \mathrm{CDCl}_{3}\right): \delta$ $158.8,148.1,131.3,129.2,128.8,117.5,114.0,112.9,55.2,47.8$. HRMS Calculated for $\mathrm{C}_{14} \mathrm{H}_{16} \mathrm{NO}[\mathrm{M}+\mathrm{H}]^{+}:$214.12264, Found: 214.12278.<smiles>c1ccc(CNc2ccccc2)cc1</smiles>

$10 \mathrm{c}$

$\mathrm{N}$-benzylbenzenamine (10c). 10c was purified by flash silica gel chromatography (HexaneEtOAc, v/v $=50: 1)$ as white solid, yield: $99 \%$. m.p. 67.3-68.2 ${ }^{\circ} \mathrm{C} .{ }^{1} \mathrm{H}$ NMR $\left(600 \mathrm{MHz}, \mathrm{CDCl}_{3}\right)$ : $\delta$ 7.43-7.39 (m, 4H), 7.35-7.32 (t, $J=7.2 \mathrm{~Hz}, 1 \mathrm{H}), 7.25-7.22(\mathrm{~m}, 2 \mathrm{H}), 6.80-6.77(\mathrm{~m}, 1 \mathrm{H}), 6.70-$ 6.69 (m, 2H), 4.38 (s, 2H), 4.09 (br, $1 \mathrm{H}) .{ }^{13} \mathrm{C}$ NMR $\left(150 \mathrm{MHz}, \mathrm{CDCl}_{3}\right): \delta 148.1,139.4,129.2$, 128.6, 127.5, 127.1, 117.6, 112.8, 48.3. HRMS Calculated for $\mathrm{C}_{13} \mathrm{H}_{14} \mathrm{~N}[\mathrm{M}+\mathrm{H}]^{+}$: 184.11207 , Found: 184.11220 .<smiles>COc1ccc(NCc2ccc(Cl)cc2)cc1</smiles>

10d

$\mathrm{N}$-(4-chlorobenzyl)-4-methoxybenzenamine (10d). 10d was purified by flash silica gel chromatography (Hexane-EtOAc, v/v $=30: 1$ ) as white solid, yield: $99 \%$. m.p. $156.1-157.8^{\circ} \mathrm{C} .{ }^{1} \mathrm{H}$ $\operatorname{NMR}\left(600 \mathrm{MHz}, \mathrm{CDCl}_{3}\right): \delta 7.30(\mathrm{~s}, 4 \mathrm{H}), 6.77-6.76(\mathrm{~m}, 2 \mathrm{H}), 6.60-6.58(\mathrm{~m}, 2 \mathrm{H}), 4.26(\mathrm{~s}, 2 \mathrm{H})$, $3.74(\mathrm{~s}, 3 \mathrm{H}) .{ }^{13} \mathrm{C}$ NMR $\left(150 \mathrm{MHz}, \mathrm{CDCl}_{3}\right): \delta 151.4,141.0,139.2,136.5,129.0,128.9,115.2$, 114.6, 56.0, 48.9. HRMS Calculated for $\mathrm{C}_{14} \mathrm{H}_{15} \mathrm{ClNO}[\mathrm{M}+\mathrm{H}]^{+}: 248.08367$, Found: 248.08373. 
<smiles>Fc1ccc(NCc2ccc(Cl)cc2)cc1</smiles>

$\boldsymbol{N}$-(4-chlorobenzyl)-4-fluorobenzenamine (10e). 10e was purified by flash silica gel chromatography (Hexane-EtOAc, v/v = 30:1) as white solid, yield: 99\%. m.p. 123.1-124.6 ${ }^{\circ} \mathrm{C} .{ }^{1} \mathrm{H}$ NMR $\left(600 \mathrm{MHz}, \mathrm{CDCl}_{3}\right): \delta$ 7.32-7.28 (m, 4H), 6.90-6.87 (m, 2H), 6.56-6.54 (m, 2H), 4.27 (s, 2H), 4.10 (br, $1 \mathrm{H}) .{ }^{13} \mathrm{C}$ NMR $\left(150 \mathrm{MHz} \mathrm{CDCl}_{3}\right): \delta 156.8,155.3,144.0,137.5,133.0,128.7$, 115.7, 113.8, 48.3. HRMS Calculated for $\mathrm{C}_{13} \mathrm{H}_{12} \mathrm{ClFN}[\mathrm{M}+\mathrm{H}]^{+}:$236.06368, Found: 236.06398.<smiles>Clc1ccc(CNCc2ccccc2)cc1</smiles>

$\mathbf{N}$-(4-chlorobenzyl)(phenyl)methanamine (10f). $10 \mathrm{f}$ was purified by flash silica gel chromatography (Hexane-EtOAc, v/v = 5:1) as white solid, yield: 95\%. m.p. 121.3-122.2 ${ }^{\circ} \mathrm{C} .{ }^{1} \mathrm{H}$ NMR (600 MHz, $\left.\mathrm{CDCl}_{3}\right): \delta$ 7.35-7.26 (m, 8H), $3.80(\mathrm{~s}, 2 \mathrm{H}), 3.78(\mathrm{~s}, 2 \mathrm{H}), 1.76(\mathrm{br}, 1 \mathrm{H}) .{ }^{13} \mathrm{C}$ NMR $\left(150 \mathrm{MHz}, \mathrm{CDCl}_{3}\right): \delta 140.0,138.7,132.6,129.5,128.5,128.4,128.1,127.0,53.0,52.3$. HRMS Calculated for $\mathrm{C}_{14} \mathrm{H}_{15} \mathrm{ClN}[\mathrm{M}+\mathrm{H}]^{+}:$232.08875, Found: 232.08887.<smiles>COc1ccc(CNCc2ccc(Cl)cc2)cc1</smiles>

$10 \mathrm{~g}$

$\mathrm{N}$-(4-chlorobenzyl)(4-methoxyphenyl)methanamine (10g). $10 \mathrm{~g}$ was purified by flash silica gel chromatography (Hexane-EtOAc, v/v = 6:1) as white solid, yield: 96\%. m.p. 168.1-170.2 ${ }^{\circ} \mathrm{C}$. ${ }^{1} \mathrm{H}$ NMR (600 MHz, $\left.\mathrm{CDCl}_{3}\right): \delta$ 7.28-7.25 (m, 4H), 7.24-7.22 (m, 2H), 6.86-6.85 (m, 2H), 3.79 (s, 3H), $3.76(\mathrm{~s}, 2 \mathrm{H}), 3.75(\mathrm{~s}, 2 \mathrm{H}), 1.52(\mathrm{br}, 1 \mathrm{H}) .{ }^{13} \mathrm{C} \mathrm{NMR}\left(150 \mathrm{MHz}, \mathrm{CDCl}_{3}\right): \delta 158.6,138.9$, 132.5, 132.2, 129.4, 129.2, 128.4, 113.8, 55.2, 52.5, 52.2. HRMS Calculated for $\mathrm{C}_{15} \mathrm{H}_{17} \mathrm{CINO}$ $[\mathrm{M}+\mathrm{H}]^{+}:$262.09932, Found: 262.09947.<smiles>COc1ccc(CNCc2ccc([N+](=O)[O-])cc2)cc1</smiles>

$\mathrm{N}$-(4-nitrobenzyl)(4-methoxyphenyl)methanamine (10h). 10h was purified by flash silica gel chromatography (Hexane-EtOAc, v/v = 8:1) as white solid, yield: 82\%. m.p. 179.0-181.2 ${ }^{\circ} \mathrm{C} .{ }^{1} \mathrm{H}$ NMR $\left(600 \mathrm{MHz}, \mathrm{CDCl}_{3}\right): \delta$ 8.18-8.17 $(\mathrm{m}, 2 \mathrm{H}), 7.53-7.51(\mathrm{~m}, 2 \mathrm{H}), 7.26-7.24(\mathrm{~m}, 2 \mathrm{H}), 6.88-$ 6.87(m, 2H), $3.89(\mathrm{~s}, 2 \mathrm{H}), 3.80(\mathrm{~s}, 3 \mathrm{H}), 3.75(\mathrm{~s}, 2 \mathrm{H}), 1.64(\mathrm{br}, 1 \mathrm{H}) .{ }^{13} \mathrm{C} \mathrm{NMR}(150 \mathrm{MHz}$, $\left.\mathrm{CDCl}_{3}\right): \delta 158.8,148.2,147.0,131.9,129.3,128.6,123.6,113.9,55.3,52.6,52.2$. HRMS Calculated for $\mathrm{C}_{15} \mathrm{H}_{17} \mathrm{~N}_{2} \mathrm{O}_{3}[\mathrm{M}+\mathrm{H}]^{+}:$273.12337, Found: 273.12350 . 
<smiles>CCCCNCc1ccc(Cl)cc1</smiles>

$10 i$

$\mathbf{N}$-(4-chlorobenzyl)butan-1-amine (10i). 10i was purified by flash silica gel chromatography (Hexane-EtOAc, v/v = 3:1) as colorless oil, yield: 91\%. ${ }^{1} \mathrm{H} \mathrm{NMR}\left(600 \mathrm{MHz}, \mathrm{CDCl}_{3}\right): \delta 7.30$ $7.26(\mathrm{~m}, 4 \mathrm{H}), 3.76(\mathrm{~s}, 2 \mathrm{H}), 2.61(\mathrm{t}, J=7.2 \mathrm{~Hz}, 2 \mathrm{H}), 1.81(\mathrm{br}, 1 \mathrm{H}), 1.53-1.48(\mathrm{~m}, 2 \mathrm{H}), 1.37-1.33$ $(\mathrm{m}, 2 \mathrm{H}), 0.91(\mathrm{t}, J=7.2 \mathrm{~Hz}, 3 \mathrm{H}) .{ }^{13} \mathrm{C} \mathrm{NMR}\left(150 \mathrm{MHz}, \mathrm{CDCl}_{3}\right): \delta 148.4,147.0,128.6,123.6$, 53.2, 49.2, 32.2, 20.4, 13.9. HRMS Calculated for $\mathrm{C}_{11} \mathrm{H}_{17} \mathrm{ClN}[\mathrm{M}+\mathrm{H}]^{+}$: 198.10440, Found: 198.10446.<smiles>Clc1ccc(CN2CCCC2)cc1</smiles>

1-(4-chlorobenzyl)pyrrolidine (10j). $\mathbf{1 0}$ j was purified by flash silica gel chromatography (Hexane-EtOAc, v/v = 3:1) as yellow oil, yield: 95\%. ${ }^{1} \mathrm{H}$ NMR $\left(600 \mathrm{MHz}, \mathrm{CDCl}_{3}\right): \delta 7.30-7.23$ $(\mathrm{m}, 4 \mathrm{H}), 3.55(\mathrm{~s}, 2 \mathrm{H}), 2.95(\mathrm{br}, 1 \mathrm{H}), 2.47-2.45(\mathrm{~m}, 4 \mathrm{H}), 1.77-1.74(\mathrm{~m}, 4 \mathrm{H}) .{ }^{13} \mathrm{C}$ NMR $(150$ $\mathrm{MHz}_{\mathrm{CDCl}}$ ): $\delta 139.6,137.7,130.2,128.3,59.9,54.0,23.4$. HRMS Calculated for $\mathrm{C}_{11} \mathrm{H}_{15} \mathrm{ClN}$ $[\mathrm{M}+\mathrm{H}]^{+}:$196.08875, Found: 196.08874.<smiles>CN(Cc1ccc(Cl)cc1)c1ccccc1</smiles>

$N$-(4-chlorobenzyl)- $N$-methylbenzenamine (10k). 10k was purified by flash silica gel chromatography (Hexane-EtOAc, v/v $=30: 1)$ as yellow oil, yield: 99\%. ${ }^{1} \mathrm{H}$ NMR $(600 \mathrm{MHz}$, $\left.\mathrm{CDCl}_{3}\right)$ : 7.30-7.28 (m, 2H), 7.25-7.22 (m, 2H), 7.18-7.17 (m, 2H), 6.75-6.74 (m, 3H), 4.50 (s, 2H), $3.01(\mathrm{~s}, 3 \mathrm{H}) .{ }^{13} \mathrm{C} \mathrm{NMR}\left(150 \mathrm{MHz}, \mathrm{CDCl}_{3}\right): \delta 149.5,137.5,132.6,129.2,128.7,128.1$, 116.9, 112.5, 56.2, 38.5. HRMS Calculated for $\mathrm{C}_{14} \mathrm{H}_{15} \mathrm{ClN}[\mathrm{M}+\mathrm{H}]^{+}$: 232.08875, Found: 232.08880 .<smiles>c1ccc(CCCNc2ccccc2)cc1</smiles>

$\boldsymbol{N}$-(3-phenylpropyl)benzenamine (101). 101 was purified by flash silica gel chromatography (Hexane-EtOAc, v/v = 35:1) as yellow oil, yield: 99\%. ${ }^{1} \mathrm{H} \mathrm{NMR}\left(600 \mathrm{MHz}, \mathrm{CDCl}_{3}\right): \delta 7.19-7.17$ $(\mathrm{m}, 2 \mathrm{H}), 7.10-7.03(\mathrm{~m}, 5 \mathrm{H}), 6.60-6.57(\mathrm{~m}, 1 \mathrm{H}), 6.46-6.44(\mathrm{~m}, 2 \mathrm{H}), 3.44(\mathrm{~b}, 1 \mathrm{H}), 3.01(\mathrm{t}, J=7.2$ $\mathrm{Hz}, 2 \mathrm{H}), 2.60(\mathrm{t}, J=7.8 \mathrm{~Hz}, 2 \mathrm{H}), 1.84-1.79(\mathrm{~m}, 2 \mathrm{H}) .{ }^{13} \mathrm{C} \mathrm{NMR}\left(150 \mathrm{MHz}, \mathrm{CDCl}_{3}\right): \delta 148.3$, 141.6, 129.1, 128.4, 128.3, 125.9, 117.1, 112.7, 43.3, 33.3, 31.0. HRMS Calculated for $\mathrm{C}_{15} \mathrm{H}_{18} \mathrm{~N}$ $[\mathrm{M}+\mathrm{H}]^{+}:$212.14338, Found: 212.14338. 
<smiles>c1ccc(NCc2ccncc2)cc1</smiles>

$\mathbf{N}$-((pyridin-4-yl)methyl)benzenamine (10m). 10m was purified by flash silica gel chromatography (Hexane-EtOAc, v/v =1:1) as yellow solid, yield: 99\%. m.p. 128.1-130.2 ${ }^{\circ} \mathrm{C} .{ }^{1} \mathrm{H}$ NMR (600 MHz, $\left.\mathrm{CDCl}_{3}\right): \delta 8.63(\mathrm{~s}, 1 \mathrm{H}), 8.53(\mathrm{~d}, J=4.8 \mathrm{~Hz}, 1 \mathrm{H}), 7.70-7.69(\mathrm{~m}, 1 \mathrm{H}), 7.27-7.25$ $(\mathrm{m}, 1 \mathrm{H}), 7.18-7.16(\mathrm{~m}, 2 \mathrm{H}), 6.76-6.73(\mathrm{~m}, 1 \mathrm{H}), 6.64-6.62(\mathrm{~m}, 2 \mathrm{H}), 4.36(\mathrm{~s}, 2 \mathrm{H}) .{ }^{13} \mathrm{C}$ NMR $(150$ $\left.\mathrm{MHz}, \mathrm{CDCl}_{3}\right): \delta 149.0,148.6,147.6,129.3,123.5,118.0,112.9,45.80$. HRMS Calculated for $\mathrm{C}_{12} \mathrm{H}_{13} \mathrm{~N}_{2}[\mathrm{M}+\mathrm{H}]^{+}:$185.10732, Found: 185.10743 .<smiles>c1ccc(NCc2ccco2)cc1</smiles>

$\boldsymbol{N}$-((furan-2-yl)methyl)benzenamine (10n). 10n was purified by flash silica gel chromatography (Hexane-EtOAc, v/v=30:1) as yellow oil, yield: 99\%. ${ }^{1} \mathrm{H}$ NMR $(600 \mathrm{MHz}$, $\left.\mathrm{CDCl}_{3}\right): \delta 7.41(\mathrm{t}, J=1.2 \mathrm{~Hz}, 1 \mathrm{H}), 7.25-7.22(\mathrm{~m}, 2 \mathrm{H}), 6.81-6.78(\mathrm{~m}, 1 \mathrm{H}), 6.73-6.71(\mathrm{~m}, 2 \mathrm{H})$, 6.37-6.36 (m, 1H), 6.28-6.27 (m, 1H), 4.35 (s, 2H), 4.02 (br, 1H). $\left.{ }^{13} \mathrm{C} \mathrm{NMR} \mathrm{(150} \mathrm{MHz,} \mathrm{CDCl}_{3}\right)$ : $\delta$ 152.7, 147.6, 141.8, 129.2, 118.0, 113.1, 110.3, 106.9, 41.4. HRMS Calculated for $\mathrm{C}_{11} \mathrm{H}_{12} \mathrm{NO}$ $[\mathrm{M}+\mathrm{H}]^{+}:$174.09134, Found: 174.09147.<smiles>O=[N+]([O-])NCc1cccs1</smiles>

$N$-((thiophen-2-yl)methyl)benzenamine (100). 100 was purified by flash silica gel chromatography (Hexane-EtOAc, v/v = 30:1) as colorless oil, yield: 99\%. ${ }^{1} \mathrm{H}$ NMR $(600 \mathrm{MHz}$, $\left.\mathrm{CDCl}_{3}\right): \delta$ 7.24-7.21 (m, 3H), 7.05-7.04 (m, 1H), 7.00-6.99 (m, 1H), 6.80-6.77 (m, 1H), 6.71$6.70(\mathrm{~m}, 2 \mathrm{H}), 4.53(\mathrm{~s}, 2 \mathrm{H}), 4.14(\mathrm{br}, 1 \mathrm{H}) .{ }^{13} \mathrm{C} \mathrm{NMR}\left(150 \mathrm{MHz}, \mathrm{CDCl}_{3}\right): \delta 147.5,142.8,129.2$, 126.8, 125.0, 124.6, 118.1, 113.2, 43.5. HRMS Calculated for $\mathrm{C}_{11} \mathrm{H}_{12} \mathrm{NS}[\mathrm{M}+\mathrm{H}]^{+}:$190.06850, Found: 190.06860 .<smiles>c1ccc(NCc2ncc[nH]2)cc1</smiles>

$N$-((1H-imidazol-2-yl)methyl)benzenamine (10p). 10p was purified by flash silica gel chromatography (Hexane-EtOAc, v/v = 4:1) as white solid, yield: $93 \%$. m.p. 195.0-197.2 ${ }^{\circ} \mathrm{C}{ }^{1} \mathrm{H}$ NMR (600 MHz, $\left.\mathrm{CDCl}_{3}\right): \delta 7.13-7.11(\mathrm{~m}, 2 \mathrm{H}), 6.97(\mathrm{~s}, 2 \mathrm{H}), 6.74-6.71(\mathrm{~m}, 1 \mathrm{H}), 6.54-6.52(\mathrm{~m}$, 2H), $4.35(\mathrm{~s}, 2 \mathrm{H}) .{ }^{13} \mathrm{C} \mathrm{NMR}\left(150 \mathrm{MHz}, \mathrm{CDCl}_{3}\right): \delta 147.5,146.6,129.3,121.9,118.4,113.1$, 
42.3. HRMS Calculated for $\mathrm{C}_{10} \mathrm{H}_{12} \mathrm{~N}_{3}[\mathrm{M}+\mathrm{H}]^{+}$: 174.10257, Found: 174.10256 .<smiles>O=C(/C=C/c1ccccc1)Nc1ccccc1</smiles>

$\mathrm{N}$-cinnamylbenzenamine (10q). 10q was purified by flash silica gel chromatography (HexaneEtOAc, v/v = 50:1) as yellow oil, yield: $95 \% .{ }^{1} \mathrm{H} \mathrm{NMR}\left(600 \mathrm{MHz}, \mathrm{CDCl}_{3}\right): \delta 7.42-7.41(\mathrm{~m}, 2 \mathrm{H})$, 7.37-7.34 (m, 2H), 7.29-7.22 (m, 3H), 6.80-6.77 (m, 1H), 6.73-6.71 (m, 2H), $6.66(\mathrm{~d}, J=15.6$ $\mathrm{Hz}, 1 \mathrm{H}), 6.37(\mathrm{dt}, J=15.6 \mathrm{~Hz} ; 6.0 \mathrm{~Hz}, 1 \mathrm{H}), 3.97(\mathrm{dd}, J=6.0 \mathrm{~Hz} ; 1.8 \mathrm{~Hz}, 2 \mathrm{H}) .{ }^{13} \mathrm{C}$ NMR $(150$ $\left.\mathrm{MHz}_{,} \mathrm{CDCl}_{3}\right): \delta 147.9,136.8,131.5,129.2,128.5,127.5,127.0,126.3,117.6,113.1,46.2$. HRMS Calculated for $\mathrm{C}_{15} \mathrm{H}_{16} \mathrm{~N}[\mathrm{M}+\mathrm{H}]^{+}: 210.12773$, Found: 210.12785.<smiles>C[C@H](NCc1ccc(Cl)cc1)c1ccccc1</smiles>

(S)-N-(4-chlorobenzyl)-1-phenylethanamine (10r). 10r was purified by flash silica gel chromatography (Hexane-EtOAc, v/v $=20: 1)$ as colorless oil, yield: $95 \%$. ${ }^{1} \mathrm{H} \mathrm{NMR}(600 \mathrm{MHz}$, $\left.\mathrm{CDCl}_{3}\right): \delta 7.29-7.28(\mathrm{~m}, 4 \mathrm{H}), 7.21-7.16(\mathrm{~m}, 5 \mathrm{H}), 3.74(\mathrm{q}, J=6.6 \mathrm{~Hz}, 1 \mathrm{H}), 3.57(\mathrm{~d}, J=13.2 \mathrm{~Hz}$, $1 \mathrm{H}), 3.50(\mathrm{~d}, J=13.2 \mathrm{~Hz}, 1 \mathrm{H}), 1.33(\mathrm{~d}, J=6.6 \mathrm{~Hz}, 3 \mathrm{H}) .{ }^{13} \mathrm{C} \mathrm{NMR}\left(150 \mathrm{MHz}, \mathrm{CDCl}_{3}\right): \delta 132.9$, $129.9,129.7,128.6,128.5,127.2,126.8,123.0,57.5,50.6,24.1$. HRMS Calculated for $\mathrm{C}_{15} \mathrm{H}_{17} \mathrm{ClN}[\mathrm{M}+\mathrm{H}]^{+}:$246.10440, Found: 246.10456.<smiles>c1ccc(CNC2CCCCC2)cc1</smiles>

$\boldsymbol{N}$-benzylcyclohexanamine (12a). 12a was purified by flash silica gel chromatography (HexaneEtOAc, v/v = 8:1) as yellow oil, yield: $95 \% .{ }^{1} \mathrm{H} \mathrm{NMR}\left(600 \mathrm{MHz}, \mathrm{CDCl}_{3}\right): \delta 7.33-7.30(\mathrm{~m}, 4 \mathrm{H})$, 7.24-7.22 (m, 1H), $3.81(\mathrm{~s}, 2 \mathrm{H}), 2.52-2.47(\mathrm{~m}, 1 \mathrm{H}), 1.93-1.91(\mathrm{~m}, 2 \mathrm{H}), 1.76-1.72(\mathrm{~m}, 2 \mathrm{H}), 1.63-$ $1.60(\mathrm{~m}, 1 \mathrm{H}), 1.30-1.10(\mathrm{~m}, 5 \mathrm{H}) .{ }^{13} \mathrm{C} \mathrm{NMR}\left(150 \mathrm{MHz}, \mathrm{CDCl}_{3}\right): \delta 141.3,128.6,128.3,127.0$, 56.4, 33.8, 26.5, 25.2. HRMS Calculated for $\mathrm{C}_{13} \mathrm{H}_{20} \mathrm{~N}[\mathrm{M}+\mathrm{H}]^{+}:$190.15903, Found: 190.15904.<smiles>Cc1ccc(NC2CCCCC2)cc1</smiles>

$12 b$

$N$-cyclohexyl-4-methylbenzenamine (12b). $12 b$ was purified by flash silica gel chromatography (Hexane-EtOAc, v/v $=50: 1$ ) as white solid, yield: 99\%. m.p. 62.1-64.6 ${ }^{\circ} \mathrm{C} .{ }^{1} \mathrm{H}$ NMR (600 MHz, $\left.\mathrm{CDCl}_{3}\right): \delta 6.99-6.98(\mathrm{~m}, 2 \mathrm{H}), 6.55-6.53(\mathrm{~m}, 2 \mathrm{H}), 3.37(\mathrm{br}, 1 \mathrm{H}), 3.26-3.22(\mathrm{~m}$, $1 \mathrm{H}), 2.25(\mathrm{~s}, 3 \mathrm{H}), 2.08-2.06(\mathrm{~m}, 2 \mathrm{H}), 1.79-1.76(\mathrm{~m}, 2 \mathrm{H}), 1.68-1.65(\mathrm{~m}, 1 \mathrm{H}), 1.41-1.35(\mathrm{~m}, 2 \mathrm{H})$, 
1.27-1.21 (m, 1H), 1.18-1.12 (m, 2H). ${ }^{13} \mathrm{C}$ NMR $\left(150 \mathrm{MHz}, \mathrm{CDCl}_{3}\right): \delta 145.4,130.0,126.3$, 113.7, 52.3, 33.8, 26.2, 25.3, 20.6. HRMS Calculated for $\mathrm{C}_{13} \mathrm{H}_{20} \mathrm{~N}[\mathrm{M}+\mathrm{H}]^{+}:$190.15903, Found: 190.15902 .<smiles>CC(Nc1ccccc1)c1ccccc1</smiles>

$N$-(1-phenylethyl)benzenamine (12c). 12c was purified by flash silica gel chromatography (Hexane-EtOAc, v/v = 30:1) as colorless oil, yield: 99\%. ${ }^{1} \mathrm{H}$ NMR $\left(600 \mathrm{MHz}, \mathrm{CDCl}_{3}\right): \delta 7.40-$ $7.39(\mathrm{~m}, 2 \mathrm{H}), 7.36-7.33(\mathrm{~m}, 2 \mathrm{H}), 7.26-7.24(\mathrm{~m}, 1 \mathrm{H}), 7.13-7.10(\mathrm{~m}, 2 \mathrm{H}), 6.69-6.66(\mathrm{~m}, 1 \mathrm{H}), 6.55-$ $6.54(\mathrm{~m}, 2 \mathrm{H}), 4.53-4.50(\mathrm{~m}, 1 \mathrm{H}), 4.14(\mathrm{br}, 1 \mathrm{H}), 1.55(\mathrm{~d}, J=6.9 \mathrm{~Hz}, 3 \mathrm{H}) .{ }^{13} \mathrm{C} \mathrm{NMR}(150 \mathrm{MHz}$, $\left.\mathrm{CDCl}_{3}\right): \delta 147.2,145.1,129.1,128.6,126.8,125.8,117.3,113.4,53.5,24.9$. HRMS Calculated for $\mathrm{C}_{14} \mathrm{H}_{16} \mathrm{~N}[\mathrm{M}+\mathrm{H}]^{+}$: 198.12773 , Found: 198.12788 .<smiles>CN(c1ccccc1)C1CCCCC1</smiles>

$\boldsymbol{N}$-cyclohexyl- $\boldsymbol{N}$-methylbenzenamine (12d). 12d was purified by flash silica gel chromatography (Hexane-EtOAc, v/v $=25: 1)$ as colorless oil, yield: $99 \%$. ${ }^{1} \mathrm{H} \mathrm{NMR}(600 \mathrm{MHz}$, $\left.\mathrm{CDCl}_{3}\right): \delta 7.25-7.22(\mathrm{~m}, 2 \mathrm{H}), 6.80-6.78(\mathrm{~m}, 2 \mathrm{H}), 6.70-6.68(\mathrm{~m}, 1 \mathrm{H}), 3.60-3.55(\mathrm{~m}, 1 \mathrm{H}), 2.78(\mathrm{~s}$, $3 \mathrm{H}), 1.86-1.79(\mathrm{~m}, 4 \mathrm{H}), 1.71-1.68(\mathrm{~m}, 1 \mathrm{H}), 1.55(\mathrm{br}, 1 \mathrm{H}), 1.50-1.43(\mathrm{~m}, 2 \mathrm{H}), 1.41-1.33(\mathrm{~m}, 2 \mathrm{H})$, 1.18-1.11 (m, 1H). ${ }^{13} \mathrm{C}$ NMR (150 MHz, $\left.\mathrm{CDCl}_{3}\right): \delta 150.0,129.1,116.2,113.2,58.2,31.1,30.0$, 26.2, 25.9. HRMS Calculated for $\mathrm{C}_{13} \mathrm{H}_{20} \mathrm{~N}[\mathrm{M}+\mathrm{H}]^{+}:$190.15903, Found: 190.15902.<smiles>CC(NCc1ccccc1)c1ccccc1</smiles>

N-benzyl-1-phenylethanamine (12e). 12e was purified by flash silica gel chromatography (Hexane-EtOAc, v/v = 8:1) as colorless oil, yield: 87\%. ${ }^{1} \mathrm{H}$ NMR $\left(600 \mathrm{MHz}, \mathrm{CDCl}_{3}\right): \delta 7.40-$ $7.25(\mathrm{~m}, 10 \mathrm{H}), 3.84(\mathrm{q}, J=6.6 \mathrm{~Hz}, 1 \mathrm{H}), 3.79(\mathrm{~d}, J=13.2 \mathrm{~Hz}, 1 \mathrm{H}), 3.62(\mathrm{~d}, J=13.2 \mathrm{~Hz}, 1 \mathrm{H})$, $1.73(\mathrm{br}, 1 \mathrm{H}), 1.40(\mathrm{~d}, J=6.6 \mathrm{~Hz}, 3 \mathrm{H}) .{ }^{13} \mathrm{C} \mathrm{NMR}\left(150 \mathrm{MHz}, \mathrm{CDCl}_{3}\right): \delta 145.5,140.6,128.4$, 128.3, 128.1, 126.9, 126.8, 126.7, 57.5, 51.6, 24.4. HRMS Calculated for $\mathrm{C}_{15} \mathrm{H}_{18} \mathrm{~N}[\mathrm{M}+\mathrm{H}]^{+}$: 212.14338, Found: 212.14339.<smiles>CCCNc1ccccc1</smiles>

$N$-(1-(furan-2-yl)ethyl)benzenamine (12f). $12 f$ was purified by flash silica gel 
chromatography (Hexane-EtOAc, v/v $=25: 1)$ as yellow oil, yield: $96 \% .{ }^{1} \mathrm{H}$ NMR $(600 \mathrm{MHz}$, $\left.\mathrm{CDCl}_{3}\right): \delta 7.31(\mathrm{~d}, J=1.2 \mathrm{~Hz}, 1 \mathrm{H}), 7.14(\mathrm{~m}, 2 \mathrm{H}), 6.69(\mathrm{t}, J=7.2 \mathrm{~Hz}, 1 \mathrm{H}), 6.61(\mathrm{~d}, J=7.8 \mathrm{~Hz}$, $2 \mathrm{H}), 6.27-6.26(\mathrm{~m}, 1 \mathrm{H}), 6.14(\mathrm{~d}, J=3.0 \mathrm{~Hz}, 1 \mathrm{H}), 4.62(\mathrm{q}, J=6.6 \mathrm{~Hz}, 1 \mathrm{H}), 3.84(\mathrm{br}, 1 \mathrm{H}), 1.53(\mathrm{~d}$, $J=6.6 \mathrm{~Hz}, 3 \mathrm{H}) .{ }^{13} \mathrm{C}$ NMR $\left(150 \mathrm{MHz}, \mathrm{CDCl}_{3}\right): \delta 157.2,147.0,141.4,129.1,117.7,113.4$, 110.0, 105.0, 47.3, 20.8. HRMS Calculated for $\mathrm{C}_{12} \mathrm{H}_{14} \mathrm{NO}[\mathrm{M}+\mathrm{H}]^{+}:$188.10699, Found: 188.10702 .<smiles>CC(C)CC(NCc1ccc2ccccc2c1)C(=O)O</smiles>

2-((naphthalene-3-yl)methylamino)-4-methylpentanoic acid (14a). 14a was purified by recrystalization as white solid, yield: $65 \% .{ }^{1} \mathrm{H}$ NMR $\left(600 \mathrm{MHz}, \mathrm{CD}_{3} \mathrm{OD}\right): \delta 8.33(\mathrm{~d}, J=8.4 \mathrm{~Hz}$, 1H), 7.97 (dd, $J=16.2 \mathrm{~Hz} ; 8.4 \mathrm{~Hz}, 2 \mathrm{H}), 7.70-7.65(\mathrm{~m}, 2 \mathrm{H}), 7.60-7.53(\mathrm{~m}, 2 \mathrm{H}), 4.76$ (d, $J=13.2$ $\mathrm{Hz}, 1 \mathrm{H}), 4.54(\mathrm{~d}, J=13.2 \mathrm{~Hz}, 1 \mathrm{H}), 3.66(\mathrm{dd}, J=8.4 \mathrm{~Hz} ; 6.0 \mathrm{~Hz}, 1 \mathrm{H}), 1.87-1.77(\mathrm{~m}, 2 \mathrm{H}), 1.63-$ $1.58(\mathrm{~m}, 1 \mathrm{H}), 1.00(\mathrm{~d}, J=6.6 \mathrm{~Hz}, 3 \mathrm{H}), 0.91(\mathrm{~d}, J=6.6 \mathrm{~Hz}, 3 \mathrm{H}) .{ }^{13} \mathrm{C}$ NMR $\left(150 \mathrm{MHz}, \mathrm{CD}_{3} \mathrm{OD}\right)$ : $\delta 135.4,133.1,131.4,130.7,129.9,128.4,127.5,126.4,124.4,63.2,41.2,26.1,23.2,22.5$. HRMS Calculated for $\mathrm{C}_{17} \mathrm{H}_{22} \mathrm{NO}_{2}[\mathrm{M}+\mathrm{H}]^{+}:$272.16451, Found: 272.16461 .<smiles>O=C(O)C(Cc1cnc[nH]1)NCc1ccc(Cl)cc1</smiles>

(S)-2-(4-chlorobenzylamino)-3-(1H-imidazol-5-yl) propanoic acid (14b). 14b was purified by recrystalization as white solid, yield: $65 \%$. ${ }^{1} \mathrm{H}$ NMR $\left(600 \mathrm{MHz}, \mathrm{CD}_{3} \mathrm{OD}\right): \delta 7.69(\mathrm{~d}, J=1.2$ $\mathrm{Hz}, 1 \mathrm{H}), 7.48-7.46(\mathrm{~m}, 2 \mathrm{H}), 7.44-7.42(\mathrm{~m}, 2 \mathrm{H}), 6.98(\mathrm{~d}, J=1.2 \mathrm{~Hz}, 1 \mathrm{H}), 4.23(\mathrm{~d}, J=13.2 \mathrm{~Hz}$, $1 \mathrm{H}), 4.16(\mathrm{~d}, J=13.2 \mathrm{~Hz}, 1 \mathrm{H}), 3.73(\mathrm{dd}, J=7.8 \mathrm{~Hz} ; 4.8 \mathrm{~Hz}, 1 \mathrm{H}), 3.23(\mathrm{dd}, J=15.6,4.8 \mathrm{~Hz}$, $1 \mathrm{H}), 3.08(\mathrm{dd}, J=15.6,4.8 \mathrm{~Hz}, 1 \mathrm{H}) .{ }^{13} \mathrm{C} \mathrm{NMR}\left(150 \mathrm{MHz}, \mathrm{CD}_{3} \mathrm{OD}\right): \delta 172.8,136.4,136.3$, 135.5, 132.6, 132.3, 130.2, 116.7, 63.6, 50.6, 49.6, 28.3. HRMS Calculated for $\mathrm{C}_{13} \mathrm{H}_{15} \mathrm{ClN}_{3} \mathrm{O}_{2}$ $[\mathrm{M}+\mathrm{H}]^{+}: 280.08473$, Found: 280.08487.<smiles>CSCCC(NCc1ccc(Cl)cc1)C(=O)O</smiles>

2-(4-chlorobenzylamino)-4-(methylthio)butanoic acid (14c). 14c was purified by recrystalization as white solid, yield: $65 \%$. ${ }^{1} \mathrm{H}$ NMR $\left(600 \mathrm{MHz}, \mathrm{CDCl}_{3}\right.$ with $\left.\mathrm{CF}_{3} \mathrm{COOH}\right): \delta 7.43$ $(\mathrm{d}, J=8.4 \mathrm{~Hz}, 2 \mathrm{H}), 7.34(\mathrm{~d}, J=8.4 \mathrm{~Hz}, 2 \mathrm{H}), 4.40(\mathrm{~d}, J=12.6,1 \mathrm{H}), 4.32(\mathrm{~d}, J=12.6,1 \mathrm{H}), 4.27$ $(\mathrm{br}, 1 \mathrm{H}), 2.70(\mathrm{br}, 2 \mathrm{H}), 2.36(\mathrm{br}, 3 \mathrm{H}), 2.12(\mathrm{br}, 2 \mathrm{H}) .{ }^{13} \mathrm{C} \mathrm{NMR}\left(150 \mathrm{MHz}, \mathrm{CDCl}_{3}\right.$ with $\left.\mathrm{CF}_{3} \mathrm{COOH}\right): \delta 137.6,131.5,130.3,126.9,59.2,51.4,30.0,27.6,15.1$. HRMS Calculated for $\mathrm{C}_{12} \mathrm{H}_{17} \mathrm{ClNO}_{2} \mathrm{~S}[\mathrm{M}+\mathrm{H}]^{+}:$274.06630, Found: 274.06636. 


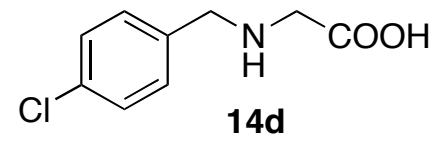

2-(4-chlorobenzylamino)acetic acid (14d). 14d was purified by recrystalization as white solid, yield: 55\%. ${ }^{1} \mathrm{H}$ NMR (600 MHz, $\left.\mathrm{CD}_{3} \mathrm{OD}\right): \delta$ 7.42-7.40 (m, 2H), 7.36-7.35 (m, 2H), $3.96(\mathrm{~s}$, 2H), 3.29 (s, 2H). ${ }^{13} \mathrm{C}$ NMR (150 MHz, $\left.\mathrm{CD}_{3} \mathrm{OD}\right): \delta$ 136.2, 135.2, 132.5, 129.9, 58.4, 54.9. HRMS Calculated for $\mathrm{C}_{9} \mathrm{H}_{11} \mathrm{ClNO}_{2}[\mathrm{M}+\mathrm{H}]^{+}: 200.04728$, Found: 200.04723 . 


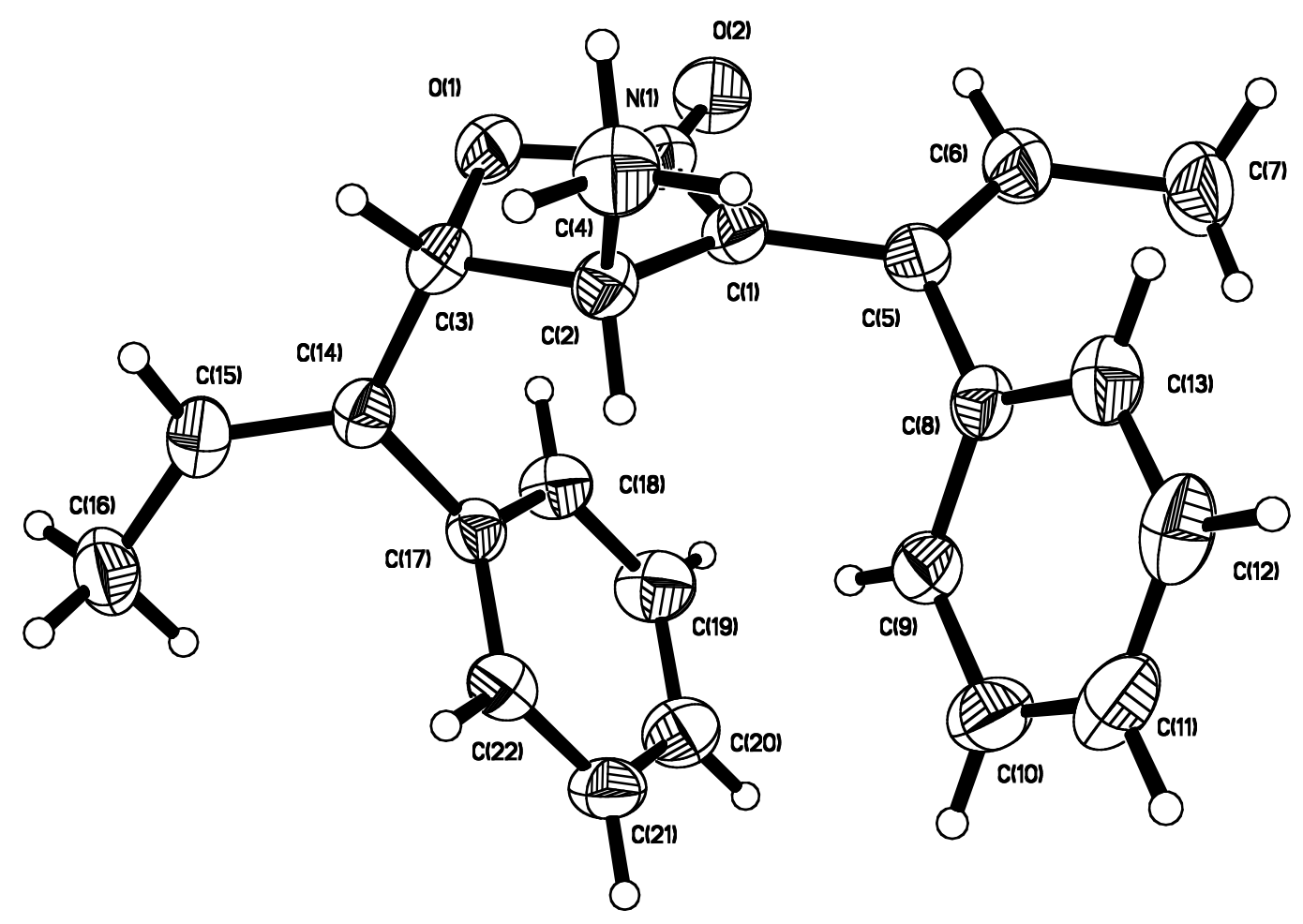

Figure 1. Perspective view of the molecular structure of $3 \mathrm{~K}\left(\mathrm{C}_{22} \mathrm{H}_{23} \mathrm{NO}_{2}\right)$ with the atom labeling scheme. The thermal ellipsoids are scaled to enclose $30 \%$ probability. CCDC number : 686861 


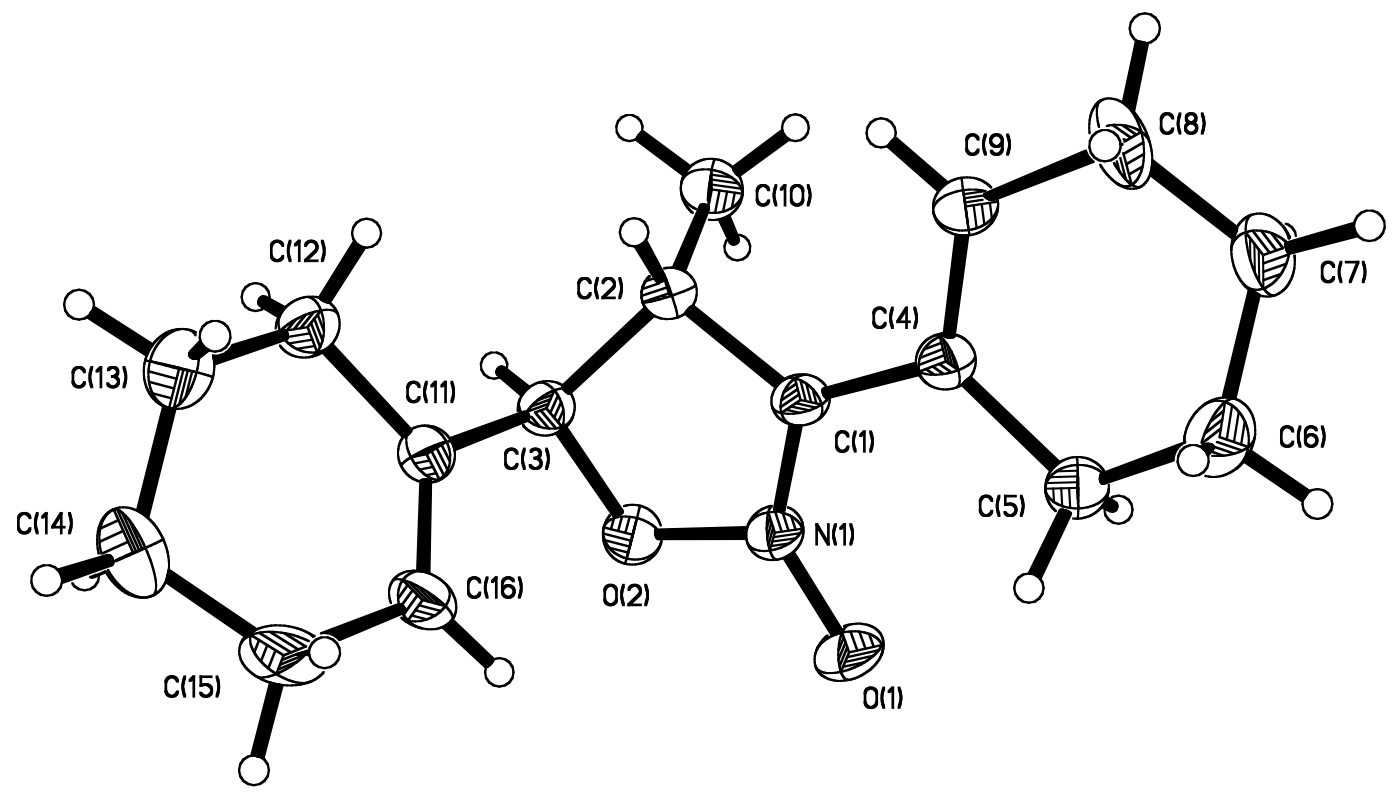

Figure 2. Perspective view of the molecular structure of $3 \mathbf{l}\left(\mathrm{C}_{16} \mathrm{H}_{23} \mathrm{NO}_{2}\right)$ with the atom labeling scheme. Each cyclohexenyl ring suffers from a two-site conformational disorder. For purposes of clarity, only the major site is depicted. The thermal ellipsoids are scaled to enclose $30 \%$ probability. CCDC number: 687371 

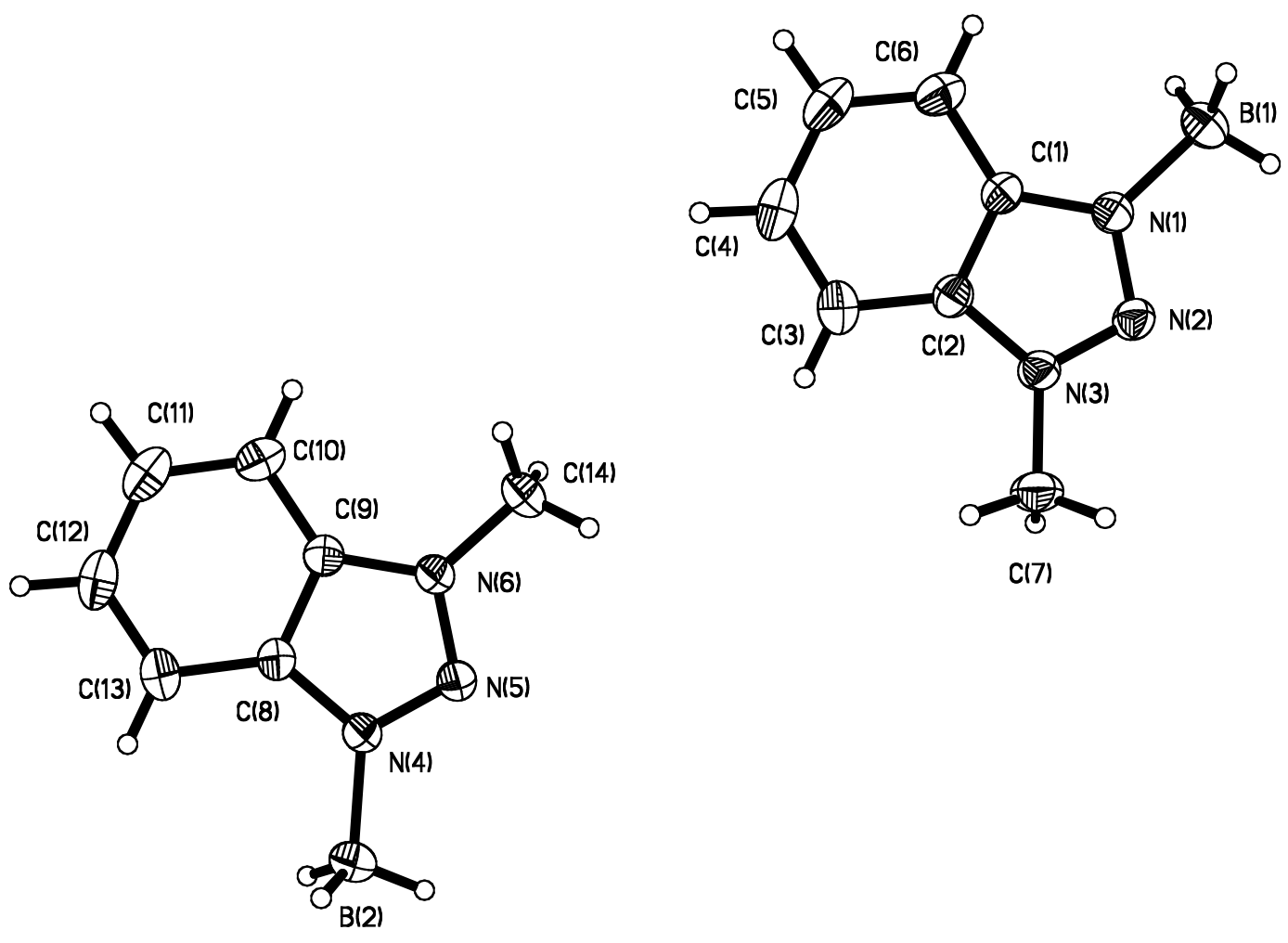

Figure 3. Perspective view of the molecular structures of the two independent molecules of $7 \mathbf{a}$ with their respective atom labeling schemes. The thermal ellipsoids are scaled to enclose 30\% probability. CCDC number: 741401. 


\section{References:}

1. Hajos, Z. G.; Parrish, D. R. German Patent DE 21026231971.

2. Hajos, Z. G.; Parrish, D. R. J. Org. Chem., 1974, 39(12), 1615-1621.

3. Eder, U.; Sauer, G.; Wiechert, R. Angew. Chem. Int. Ed., 1971, 10, 7, 496-497.

4. (a) Denmark, S. E.; Beutner, G. L. Angew. Chem. Int. Ed., 2008, 47, 1560-1638.

(b)Lewis Acids in Organic Synthesis (Ed.: H. Yamamoto) Wiley-VCH, Weinheim, 2000

5. (a) Righi, P.; Marotta, E.; Landuzzi, A.; Rosini, G. J. Am. Chem. Soc., 1996, 118, 9446; (b) Trost, B. M.; Chupak, L. S.; Lubbers, T. J. Am. Chem. Soc., 1998, 120, 1732; (c) Fuller, A. A.; Chen, B.; Minter, A. R.; Mapp, A. K. J. Am. Chem. Soc., 2005, 127, 5376.

6. (a) Barbachyn, M. R.; Cleek, G. J.; Dolak, L. A.; Garmon, S. A.; Morris, J.; Seest, E. P.; Thomas, R. C.; Toops, D. S.; Watt, W.; Wishka, D. G.; Ford, C. W.; Zurenko, G. E.; Hamel, J. C.; Schaadt, R. D.; Stapert, D.; Yagi, B. H.; Adams, W. J.; Friis, J. M.; Slatter, J. G.; Sams, J. P.; Oien, N. L.; Zaya, M. J.; Wienkers, L. C.; Wynalda, M. A. J. Med. Chem., 2003, 46, 284; (b) Simoni, D.; Grisolia, G.; Giannini, G.; Roberti, M.; Rondanin, R.; Piccagli, L.; Baruchello, R.; Rossi, M.; Romagnoli, R.; Invidiata, F. P.; Grimaudo, S.; Jung, M. K.; Hamel, E.; Gebbia, N.; Crosta, L.; Abbadessa, V.; Cristina, A. D.; Dusonchet, L.; Meli, M.; Tolomeo, M. J. Med. Chem., 2005, 48, 723.

7. Tartakovskii, V. A.; Onishchenko, A. A.; and Novikov, S. S. Zh. Org. Khim.,1967, 3, 588.

8. Chlenov, I. E.; Kashutina, M. V.; Ioffe, S. L.; Novikov, S. S.; Tartakovsky, V. A. Bull. Acad. Sci. USSR, DiV. Chem. Sci. (Engl. Transl.), 1969, 18, 1948.

9. Kunetsky, R. A.; Dilman, A. D.; Ioffe, S. L.; Struchkova, M. I.; Strelenko, Y. A.; and Tartakovsky, V. A. Org. Lett., 2003, 5, 25, 4907-4909.

10. Clagett, M.; Gooch, A.; Gzaham, P.; Holy, N.; Mains, B.; and Strunk, J. J. Org. Chem., 1976, 41, 25, 4033-4034.

11. Marotta, E.; Baravelli, M.; Maini, L.; Righi, P.; and Rosini, G. J. Org. Chem., 1998, 63, 8235-8246.

12. Denmark, S. E.; and Middleton, D. S. J. Org. Chem., 1998, 63, 1604.

13. Righi, P.; Marotta, E.; Landuzzi, A.; and Rosini, G. J. Am. Chem. Soc., 1996, 118, 94469447.

14. Sun, X.; Sengupta, S.; Petersen, J. P.; Wang, H.; Lewis, J. P.; Shi, X. Org. Lett., 2007, 9, 4495-4498. 
15. (a) Brown, H. C. Boranes in Organic Chemistry, Cornell University Press, Ithaca, 1972; (b) Brown, H. C.; von Ragu Schleyer, P. The Nonclassical Ion Problem, Plenum Press, New York, 1977; (c) Brown, H. C. Hydroboration, W. A. Benjamin, Inc., New York, 1962; (d) Brown, H. C. Organic Syntheses via Boranes, Wiley, New York, 1975;

(e) Brown, H. C.; Zaidlewicz, M. Organic Syntheses via Boranes Vol. 2: Recent Developments, Aldrich Chemical Company, Milwaukee, 2001; (f) Brown, H. C.; Zweifel, G. J. Am. Chem. Soc., 1961, 83, 486 - 487.

16. Paquette, L. A.; Gao, Z.; Smith, G. F. Tetrahedron Lett., 1997, 38, 1271.

17. Amedia Jr., J. C.; Bernard, P.J.; Fountain, M.; Van Wagenen Jr., G. Syn. Commun., 1999, 29(14), 2377.

18. Boal, J. H.; Wilk, A.; Scremin, C. L.; Gray, G .N.; Phillips, L. R.; Beaucage, S. L. J. Org. Chem., 1996, 61, 8617.

19. Elizabeth, B.; Attlesey, A. J. PCT Int. Appl., 2008, WO 2008000678

20. Crich, D. C.; Santhosh, N. PCT Int. Appl., 2004, WO 2004011472

21. Corey, E.J.; Helal, C. J. Angew. Chem. Int. Ed., 1998, 1986.

22. Burghard, A.; Lang, H.-J.; Gerlach, U. Tetrahedron, 1999, 55, 7555.

23. Burg, A. B.; Wagner, R. I. J. Am. Chem. Soc., 1953, 75, 3872-3877.

24. Matsuo, J. I.; Aizawa, Y. Tetrahedron Lett., 2004, 45, 407-410.

25. Diver, S. T.; Giessert, A. J. Chem. Reviews, 2004, 104, 1317-1382.

26. Juge, S. Taylor \& Francis Group LLC., 2008, 183, 233-248.

27. Burg, A. B.; and Schlesinger, H. I. J. Am. Chem. Soc., 1973, 59, 780.

28. Hirokawa, T.; et al. Org. Proc. Res. \& Dev., 2002, 6, 28.

29. Dahanukar, V.H. et al. (Schering Corp.) US Pat. Appl., 2003, 2003199690.

30. Salunkhe, A. M.; Burkhardt, E. R. Tetrahedron Lett., 1997, 38, 1520-1523.

31. Wilkinson, H.S.; Tanoury, G.J.; Wald, S.A.; Senanayake, C. H. Org. Proc. Res. \& Dev., 2002, 6, 146.

32. Wu, P.-L; Chen, H.-C; Line, M.-L. J. Org. Chem., 1997, 62, 1532. 
33. Marcantoni, E.; et al. J.Org. Chem., 1998, 63, 3624.

34. Sato, S.; Sakamoto, T.; Miyazawa, E.; Kikugawa, Y. Tetrahedron, 2004, 60, 7899.

35. Lane, C. F. Aldrich. Acta., 1973, 6 (3), 51-58.

36. Burnham, B. S. Curr. Med. Chem., 2005, 12, 1995-2010.

37. (a) Shriver, D. F. J. Am. Chem. Soc., 1963, 85, 3509 - 3510; (b) Parshall, G. W. J. Am. Chem. Soc., 1964, 86, 361 - 364; (c) Johnson, M. P.; Shriver, D. F. J. Am. Chem. Soc.,1966, 88, $301-304$.

38. (a) Hill, A. F.; Owen, G. R.; White, A. J. P.; Williams, D. J. Angew. Chem., 1999, 111, 2920 - 2923; Angew. Chem. Int. Ed., 1999, 38, 2759 - 2761; (b) Foreman, M. R. St.-J.; Hill, A. F.; White, A. J. P.; Williams, D. J. Organometallics, 2004, 23, $913-916$.

39. Lu, N.; Norman, N. C.; Orpen, A. G.; Quayle, M. J.; Timms, P. L.; Whittell, G. R. J. Chem. Soc. Dalton Trans., 2000, 4032 - 4037.

40. (a) Braunschweig, H.; Kollann, C.; Englert, U. Eur. J. Inorg. Chem., 1998, 465 - 468; (b) Braunschweig, H.; Kollann, C.; Klinkhammer, K.W. Eur. J. Inorg. Chem., 1999, 1523-1529.

41. Braunschweig, H.; Radacki, K.; Uttinger, D. Rais, K. Angew. Chem., 2006, 118, 169 - 172; Angew. Chem. Int. Ed., 2006, 45, 162-165.

42. Wang, Y.; Quillian, B.; Wei, P.; Wannere, C. S.; Xie, Y.; King, R. B.; Schaefer, H. F., III; v. R. Schleyer, P.; Robinson, G. H. J. Am. Chem. Soc., 2007, 129, 12412.

43. Ueng, S-H.; Brahmi, M. M.; Derat, E.; Fensterbank, L.; Lacote, E.; Malacria, M.; and Curran, D. P. J. Am. Chem. Soc., 2008, 130, 10082-10083.

44. (a) Robichaud, A.; Ajjou, A. N. Tetrahedron Lett., 2006, 47, 3633. (b) Ohkuma, T.; Noyori, R.; Jacobsen, E. N.; Pfaltz, A.; Yamamoto, H. E. Springer: New York, 2004. (c) Tararov, V. I.; Borner, A. Synlett., 2005, 203. (d) Gomez, S.; Peters, J. A.; Maschmeyer, T.J. Synth. Catal., 2002, 344, 1037.

45. Abdel-Magid, A. F.; Carson, K. G.; Harris, B. D.; Maryanoff, C. A.; Shah, R. D. J. Org. Chem., 1996, 61, 3849.

46. Dietrich, E.; Lubell, W. D. J. Org. Chem., 2003, 68, 6988.

47. (a) Gray, G. Arch. Biochem. Biophys., 1974, 163, 426; (b) Marsh, J. W.; Denis, J.; Wriston, J. C. J. Biol. Chem., 1977, 252, 7678; (c) Wilson, G. J. Biol. Chem., 1978, 253, 2070; (d) Lee, H. S.; Sen, L. C.; Chifford, A. J.; Whitakar, J. R.; Feeney, R. E. J. Agric. Food Chem., 1979, 27, 1094. 
48. Bae, J. W.; Lee, S. H.; Cho, Y. J.; Yoon, C. M. J. Chem. Soc. Perkin Trans. 1, $2000,145$.

49. Zhu, G.; Zhang, X. Tetrahedron Asymmetry, 1998, 9, 2415.

50. Cimarelli, G.; Palmen, G. Tetrahedron Asymmetry, 2000, 11, 2555.

51. (a) Abdel-Magid, A. F.; Carson, K. G.; Harris, B. D.; Maryanoff, C. A.; Shah, R. D. J. Org. Chem., 1996, 61, 3849; (b) Miriyala, B.; Bhattacharyya, S.; Williamson, J. S. Tetrahedron, 2004, 60, 1463.

52. Kumpaty, H. J.; Williamson, J. S.; Bhattacharyya, S. Synth. Commun., 2003, 33, 1411.

53. Saxena, I.; Borah, R.; and Sarma, J. C. J. Chem. Soc. Perkin Trans. 1, 2000, 503-504.

54. Alinezhad, H.; Ardestani, E. Lett. Org. Chem., 2007, 4, 473.

55. Heydari, A.; Arefi, A.; Esfandyari, M. J. Mol. Catal. A, 2007, 274, 169.

56. Varma, R. S.; Dahiya, R. Tetrahedron, 1998, 54, 6293.

57. Alinezhad, H.; Tajbakhsh, M.; Salehian, F. Monatsh. Chem., 2005, 136, 2029.

58. Yoon, N. M.; Kim, E. G.; Son, H. S.; Choi, J. Synth. Commun., 1993, 23, 1595.

59. Richard, F. B.; Mark, L.; Bernstein, D.; Dupont, D. H. J. Am. Chem. Soc., 1971, 93, 2897.

60. Borch, R. F.; Durst, H. D. J. Am. Chem. Soc., 1969, 91, 3996.

61. Hutchins, R. O.; Markowitz, M. J. Org. Chem., 1981, 46, 3571.

62. Kim, S.; Oh, C. H.; Ko, J. S.; Ahn, K. H.; Kim, Y. J. J. Org. Chem., 1985, 50, 1927.

63. Mattson, R. J.; Pham, K. M.; Leuck, D. J.; Cowen, K. A. J. Org. Chem., 1990, 55, 2552.

64. Brussee, J.; van Benthem, R. A. T. M.; Kruse, C. G.; van der Gen, A. Tetrahedron Asynmmetry, 1990, 1, 163.

65. Abdel-Magid, A. F.; Carson, K. G.; Harris, B. D.; Maryanoff, C. A.; and Shah, R. D. J. Org. Chem., 1996, 61(11), 3849-3862.

66. Hamza, D.; Stocks, M. J.; Décor, A.; Pairaudeau, G.; Stonehouse, J. P. Synlett, 2007, 2584.

67. Suki, H. K.; Shimura, N. Y.; Kadota, I.; Ushio, Y.; Ochi, M. Synthesis, 1990, 401.

68. Bhattacharyya, S.; Chatterjee, A.; Williamson, J. S. Synth. Commun., 1997, 27, 4265. 
69. Ranu, B. C.; Majee, A.; Sarkar, A. J. Org. Chem., 1998, 63, 370.

70. Alinezhad, H.; Tajbakhsh, M.; Salehian, F.; Fazli, K. Tetrahedron Lett., 2009, 50, 659-661.

71. Firouzabadi, H.; Iranpoor, N.; Alinezhad, H. Bull. Chem. Soc. Jpn., 2003, 76, 143.

72. Bhanushali, M. J.; Nandurkar, N. S.; Bhor, M.; Bhanag, B. M. Tetrahedron Lett., 2007, 48, 1273.

73. Seo, J. H.; Adachi, K.; Lee, B. K.; Kang, D. G.; Kim, Y. K.; Kim, K. R.; Lee, H. Y.; Kawai, T.; Cha, H. J. Bioconjug. Chem., 2007, 18, 2197.

74. Bomann, M. D.; Guch, I. C.; DiMare, M. J. Org. Chem., 1995, 60, 5995.

75. Burkhardt, E. R.; Coleridge, B. M. Tetrahedron Lett., 2008, 49, 5152-5155.

76. Pereyre, M.; Quintard, J. P.; Rahm Butterworths: London, 1987.

77. Shibata, I.; Baba A. Curr. Org. Chem., 2002, 6, 665.

78. (a) Suwa, T.; Sugiyama, E.; Shibata, I.; Baba, A. Synthesis, 2000, 789; (b) Suwa, T.; Sugiyama, E.; Shibata, I.; Baba, A. Synlett, 2000, 556.

79. Takashi, I.; Kazuhiro, N.; Michiko, M.; Hyroyuki, I. Tetrahedron, 2004, 60, 6649.

80. Tuttle, J. B.; Ouellet, S. G.; MacMillan, D. W. C. J. Am. Chem. Soc., 2006, 128, 12662.

81. (a) Pihko, P. M. Angew. Chem. Int. Ed. Engl., 2004, 43, 2062; (b) Schreiner, P. Chem. Soc. Rev., 2003, 32, 289.

82. Itoh, T.; Nagata, K.; Miyazaki, M.; Ishikawa, H.; Kurihara, A.; Ohsawa, A. Tetrahedron, 2004, 60, 6649.

83. (a) Wu, P.; Feldman, A. K.; Nugent, A. K.; Hawker, C. J.; Scheel, A.; Voit, B.; Pyun, J.; Frechet, J. M. J.; Sharpless, K. B.; Fokin, V. V. Angew. Chem., Int. Ed., 2004, 43, 3928-3932; (b) Aucagne, V.; Ha“nni, K. D.; Leigh, D. A.; Lusby, P. J.; Walker, D. B. J. Am. Chem. Soc., 2006, 128, 2186-2187; (c) Ye, C. F.; Gard, G. L.; Winter, R. W.; Syvret, R. G.; Twamley, B.; Shreeve, J. M. Org. Lett., 2007, 9, 3841-3844; (d) Liu, Q. C.; Zhao, P.; Chen, Y. M. J. Polym. Sci., Part A: Polym. Chem., 2007, 45, 3330-3341.

84. (a) Agard, N. J.; Prescher, J. A.; Bertozzi, C. R. J. Am. Chem. Soc., 2004, 126, 15046-15047; (b) Moorhouse, A. D.; Santos, A. M.; Gunaratnam, M.; Moore, M.; Neidle, S.; Moses, J. E. J. Am. Chem. Soc., 2006, 128, 15972-15973; (c) Kumar, R.; El-Sagheer, A.; Tumpane, J.; Lincoln, P.; Wilhelmsson, L. M.; Brown, T. J. Am. Chem. Soc., 2007, 129, 6859-6864. 
85. (a) Manetsch, R.; Krasiski, A.; Radi, Z.; Raushel, J.; Taylor, P.; Sharpless, K. B.; Kolb, H. C. J. Am. Chem. Soc., 2004, 126, 12809-12818; (b) Wang, J.; Sui, G.; Mocharla, V. P.; Lin, R. J.; Phelps, M. E.; Kolb, H. C.; Tseng, H.-R. Angew. Chem., Int. Ed., 2006, 45, 5276-5281; (c) Sugawara, A.; Sunazuka, T.; Hirose, T.; Nagai, K.; Yamaguchi, Y.; Hanaki, H.; Sharpless, K. B.; Omura, S. Bioorg. Med. Chem. Lett., 2007, 17, 6340-6344; (d) Chen, H.; Taylor, J. L.; Abrams, S. R. Bioorg. Med. Chem. Lett., 2007, 17, 1979-1983.

86. (a) Rostovtsev, V. V.; Green, L. G.; Fokin, V. V.; Sharpless, K. B. Angew. Chem., Int. Ed., 2002, 41, 2596-2599; (b) Kolb, H. C.; Finn, M. G.; Sharpless, K. B. Angew. Chem., Int. Ed., 2001, 40, 2004-2021; (c) Bock, V. D.; Hiemstra, H.; Van Maarseveen, J. H. Eur. J. Org. Chem., 2006, 51-68; (d) Moses, J. E.; Moorhouse, A. D. Chem. Soc. Rev., 2007, 36, 1249-1262.

87. Sengupta, S.; Duan, H.; Lu, W.; Petersen, J. L.; Shi, X. Org. Lett., 2008, 10, 7, 1493-1496.

88. Duan, H.; Sengupta, S.; Petersen, J. L.; Shi, X. Organometallics, 2009, 28, 2352-2355.

89. Duan, H.; Sengupta, S.; Petersen, J. L.; Akhmedov, N. G.; Shi, X. J. Am. Chem. Soc., 2009, $131,12100-12102$. 


\section{${ }^{1}$ H-NMR and ${ }^{13}$ C-NMR Spectra}

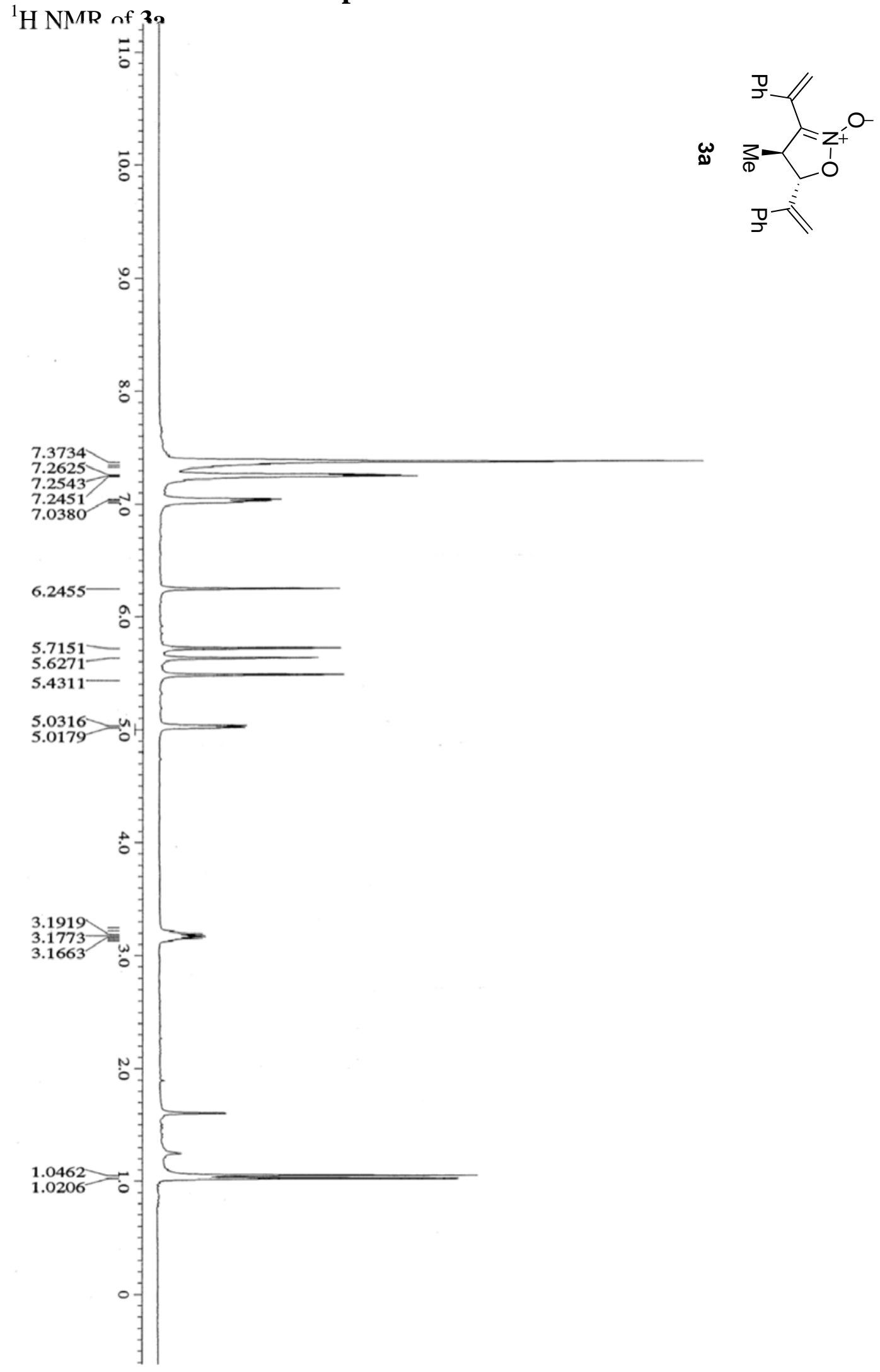




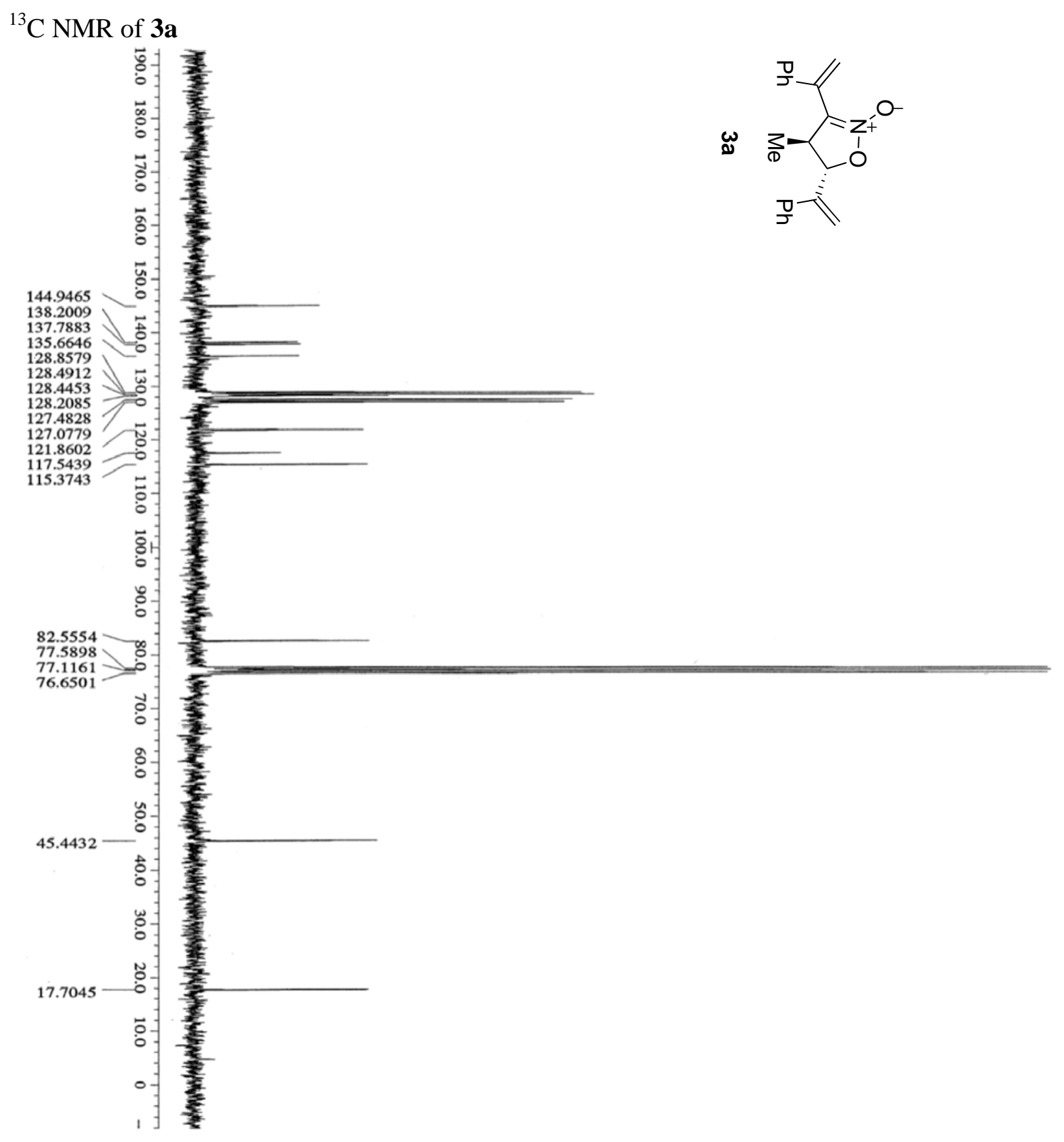




\section{${ }^{1} \mathrm{H}$ NMR of $\mathbf{3 b}$}

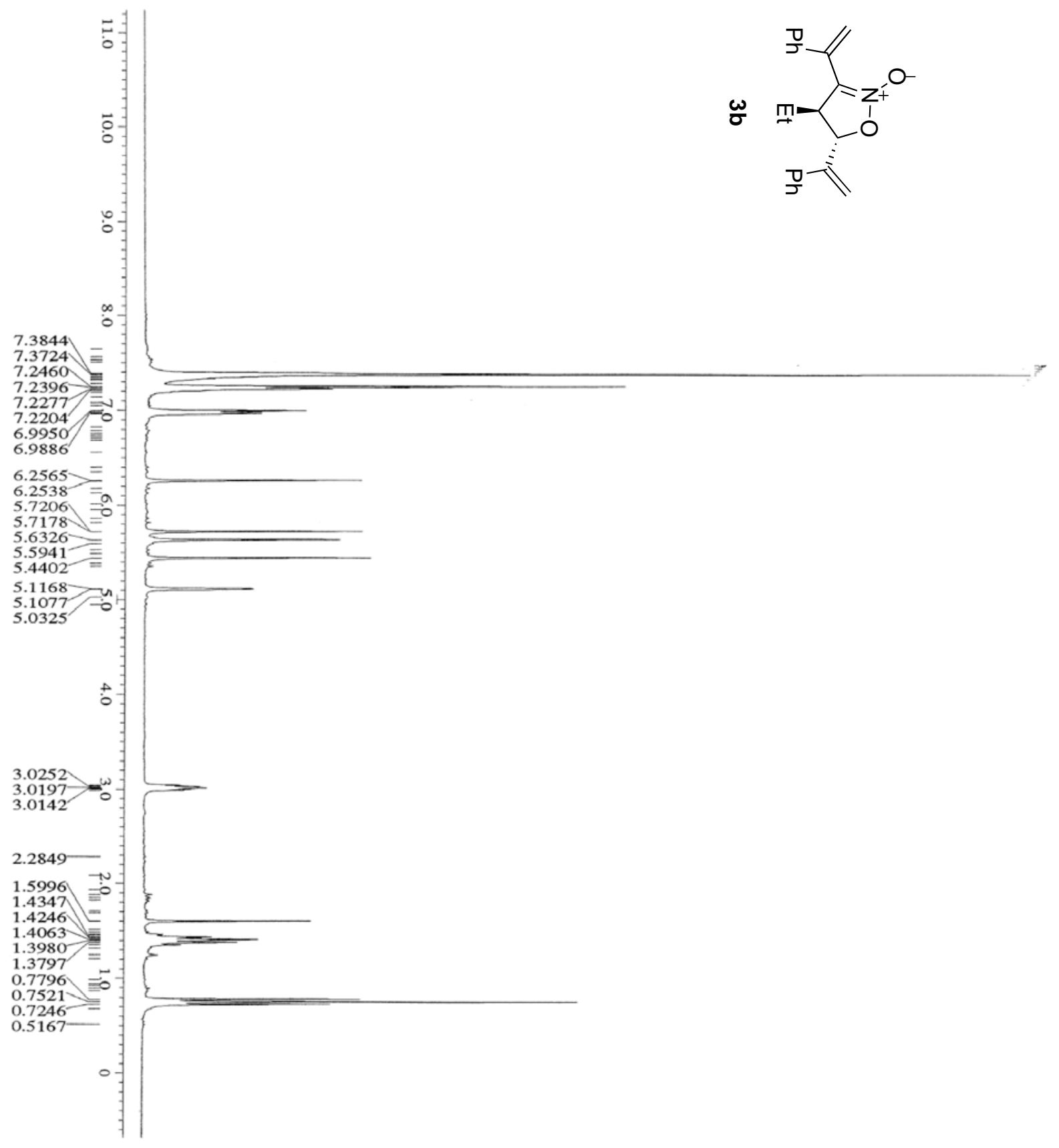


${ }^{13} \mathrm{C}$ NMR of $\mathbf{3 b}$

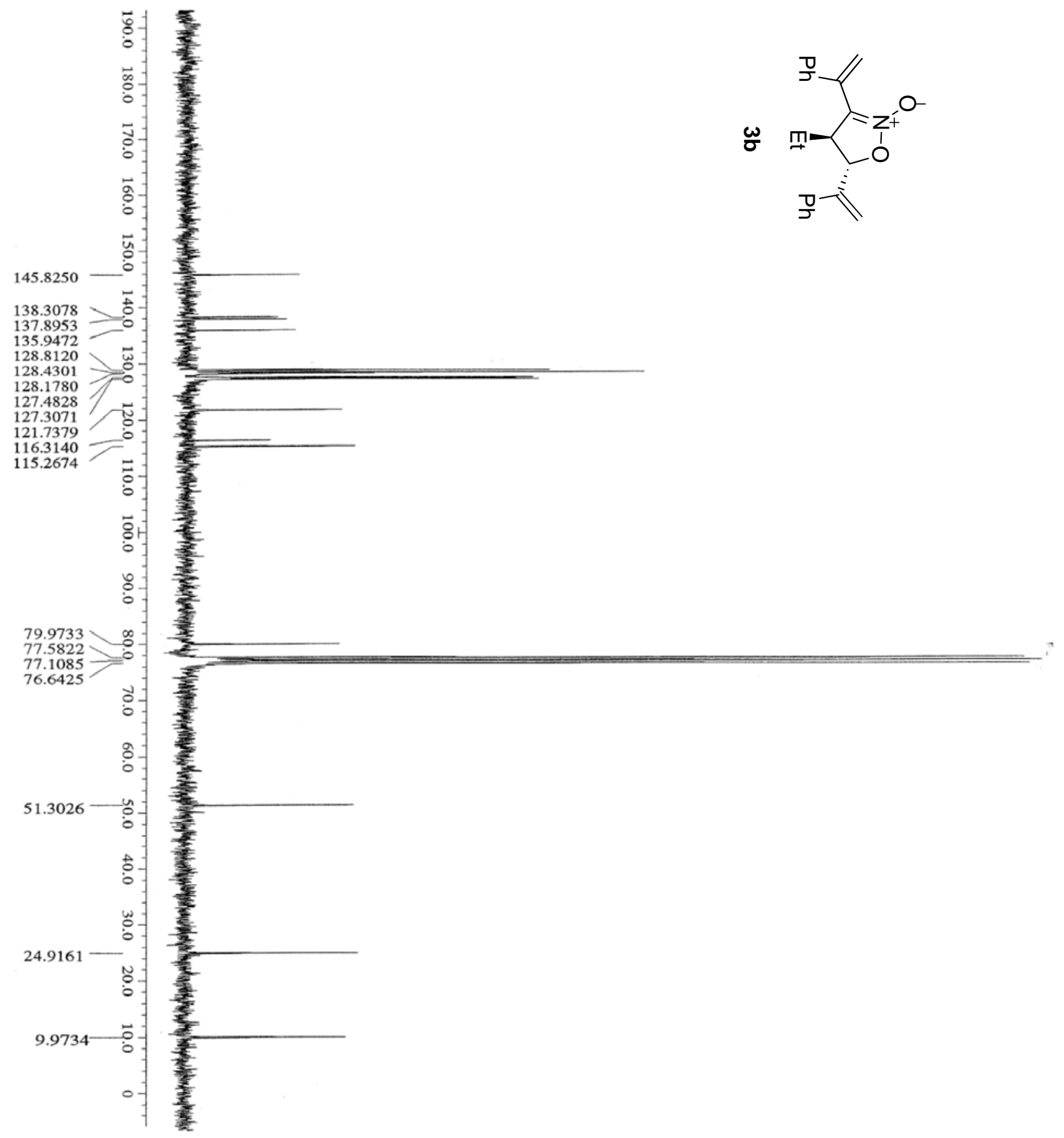




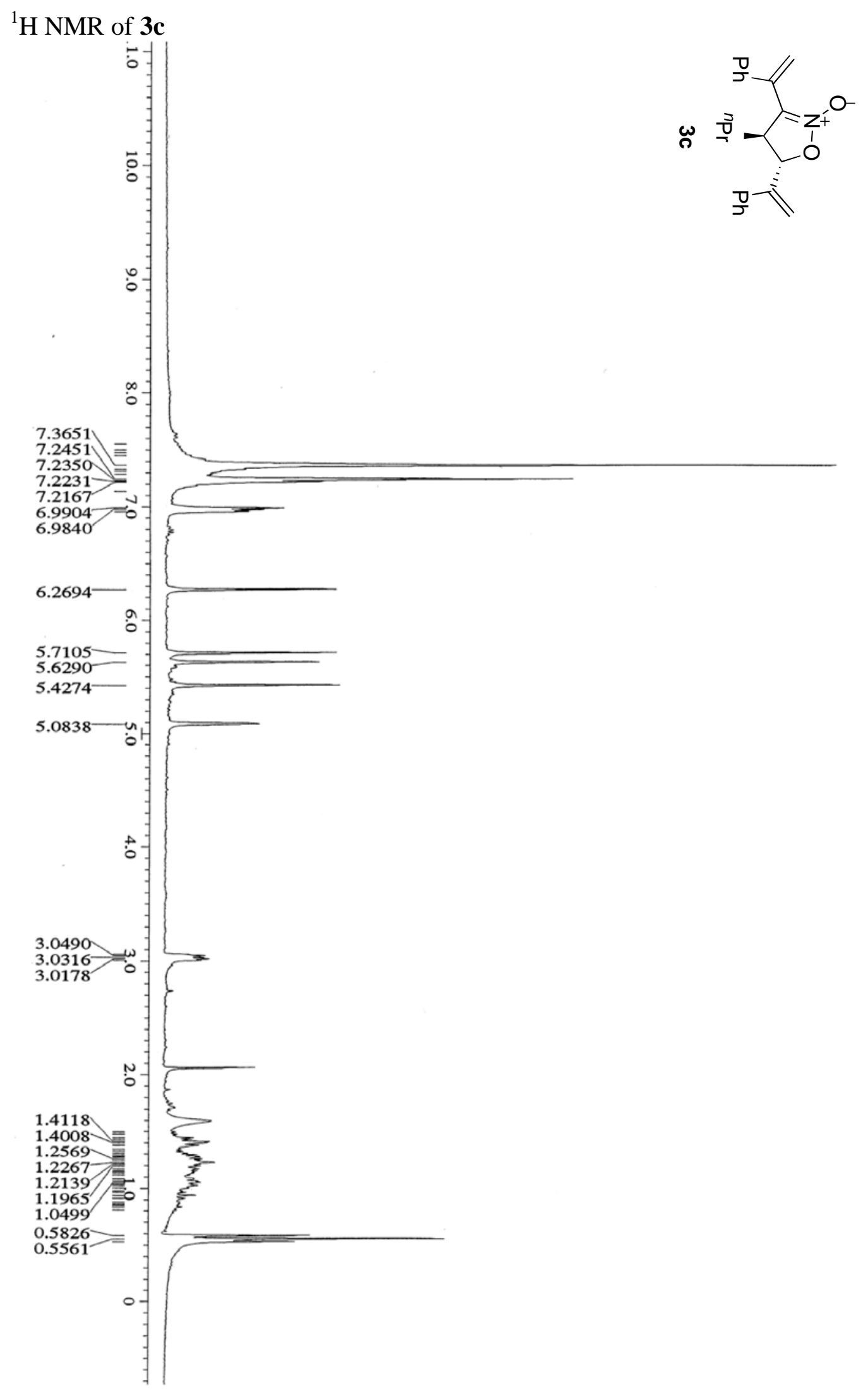




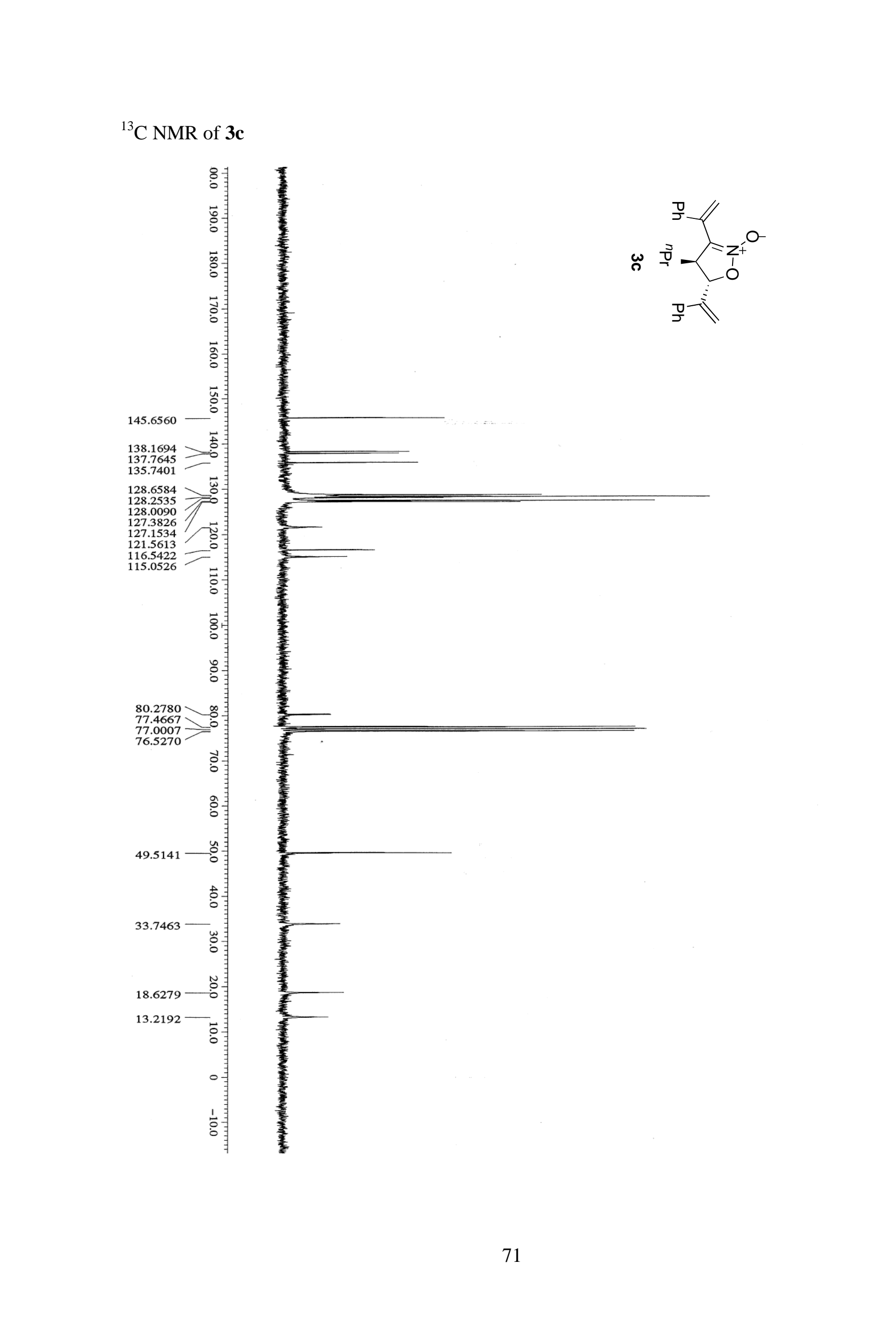


${ }^{1} \mathrm{H}$ NMR of 3d

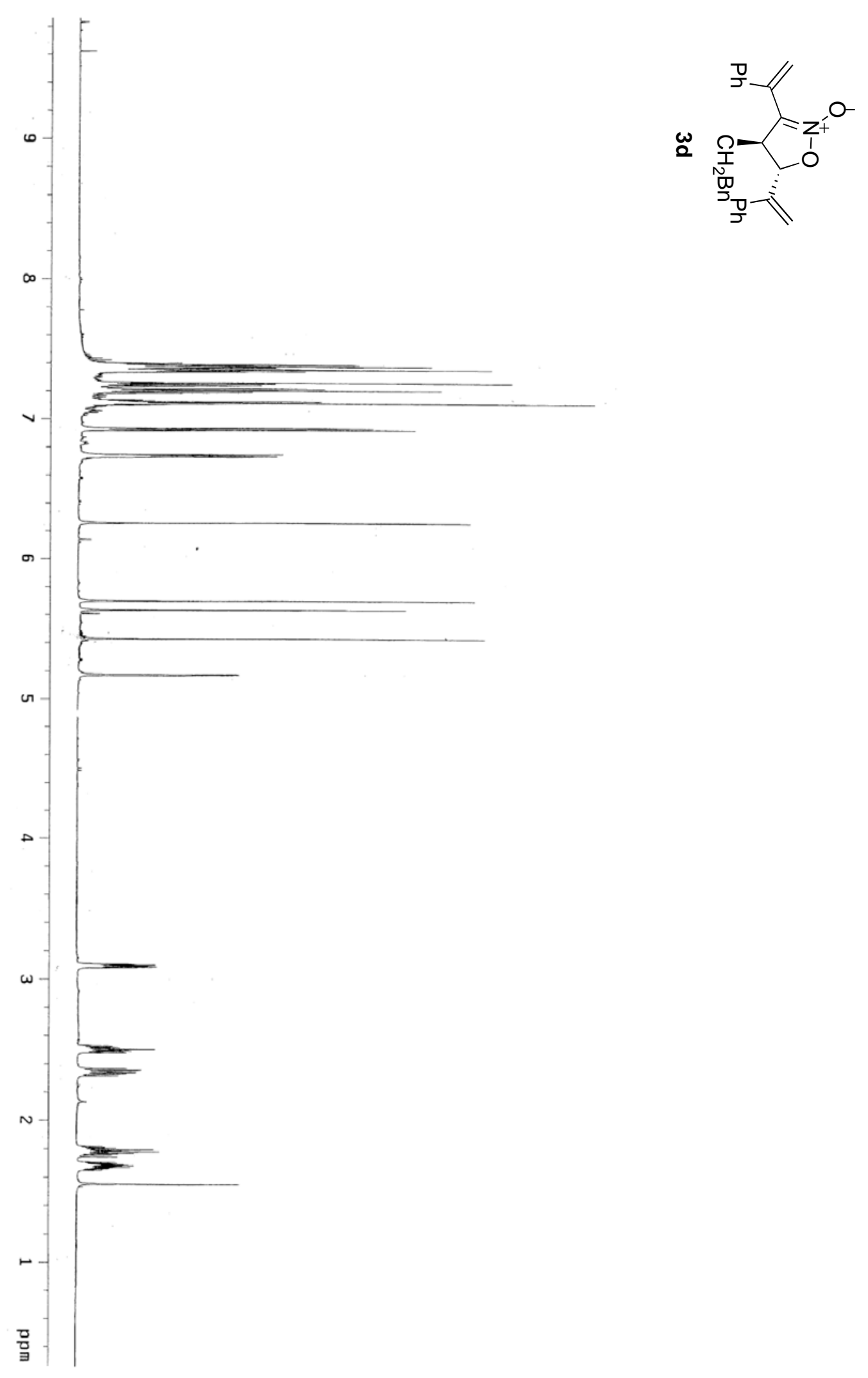


${ }^{13}$ C NMR of 3d

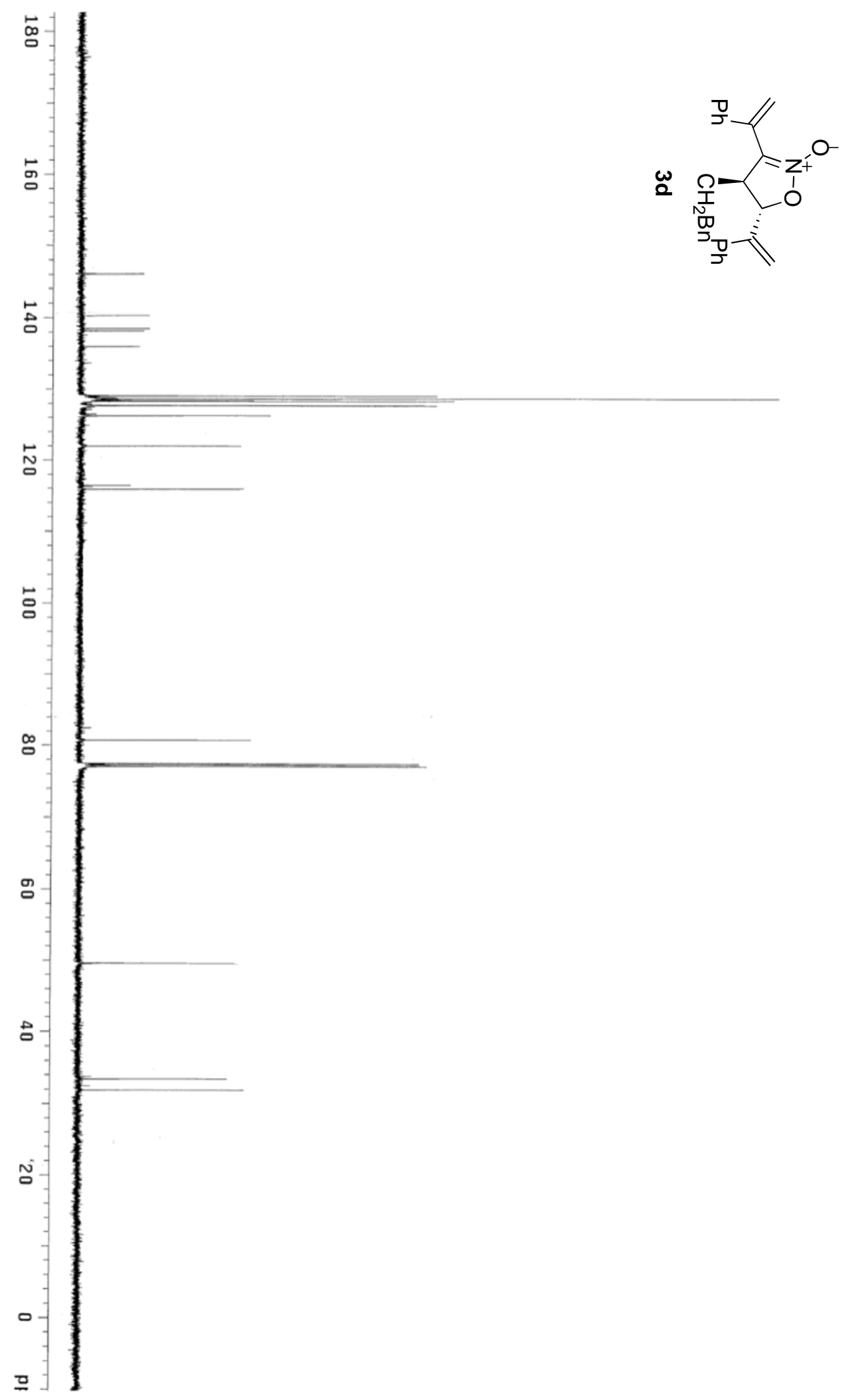




\section{${ }^{1} \mathrm{H}$ NMR of $3 \mathbf{e}$}

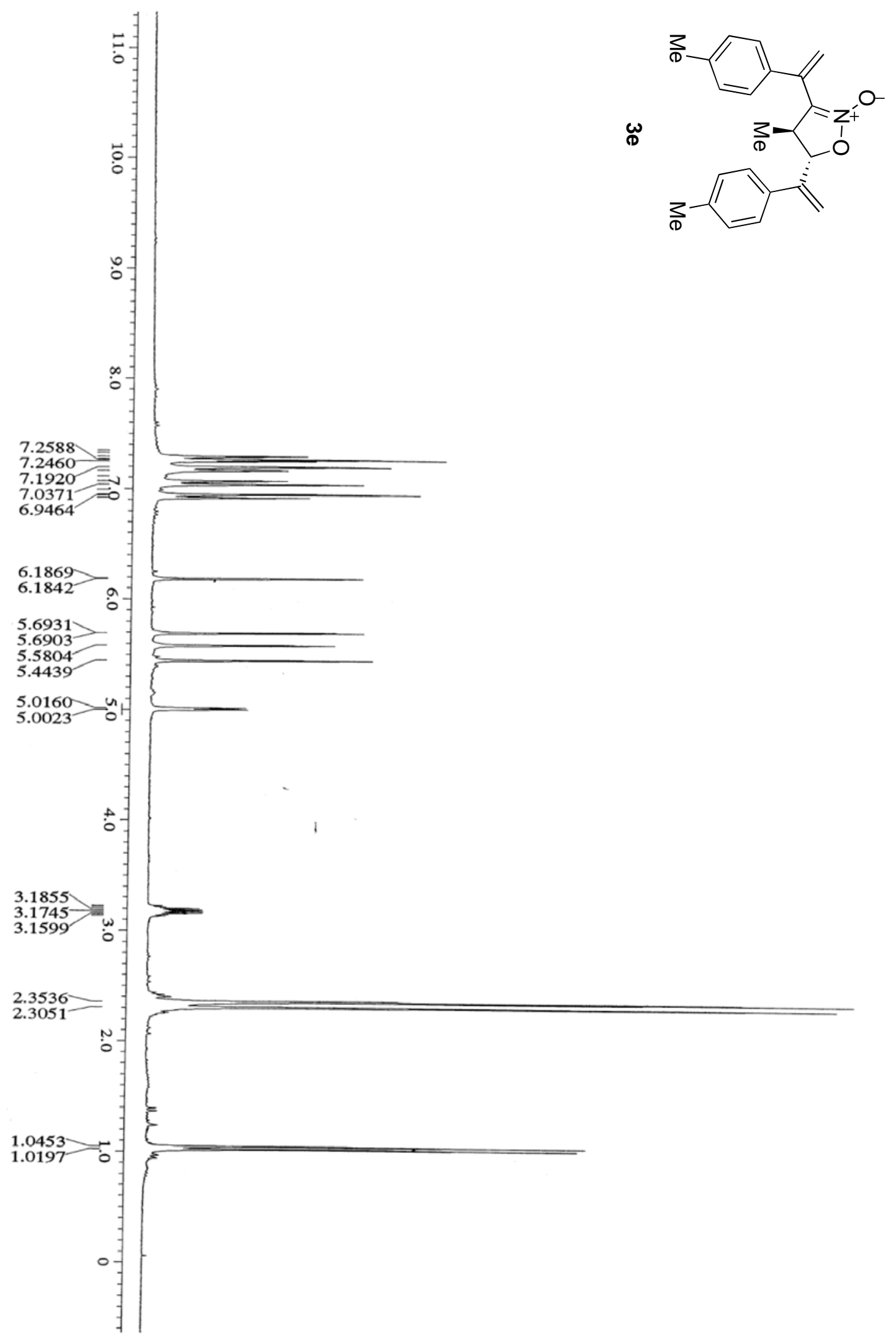




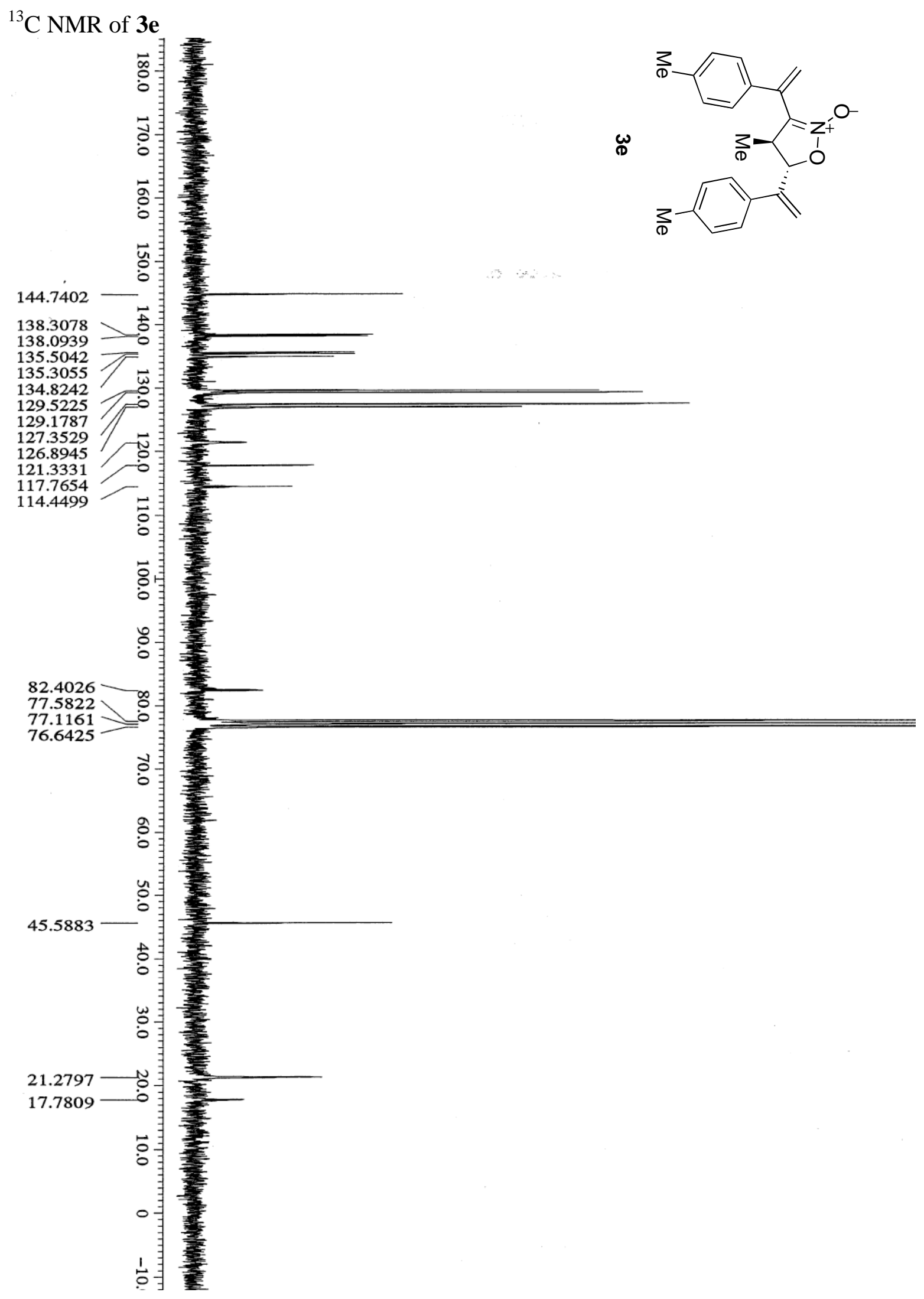




\section{${ }^{1}$ H NMR of $3 f$}

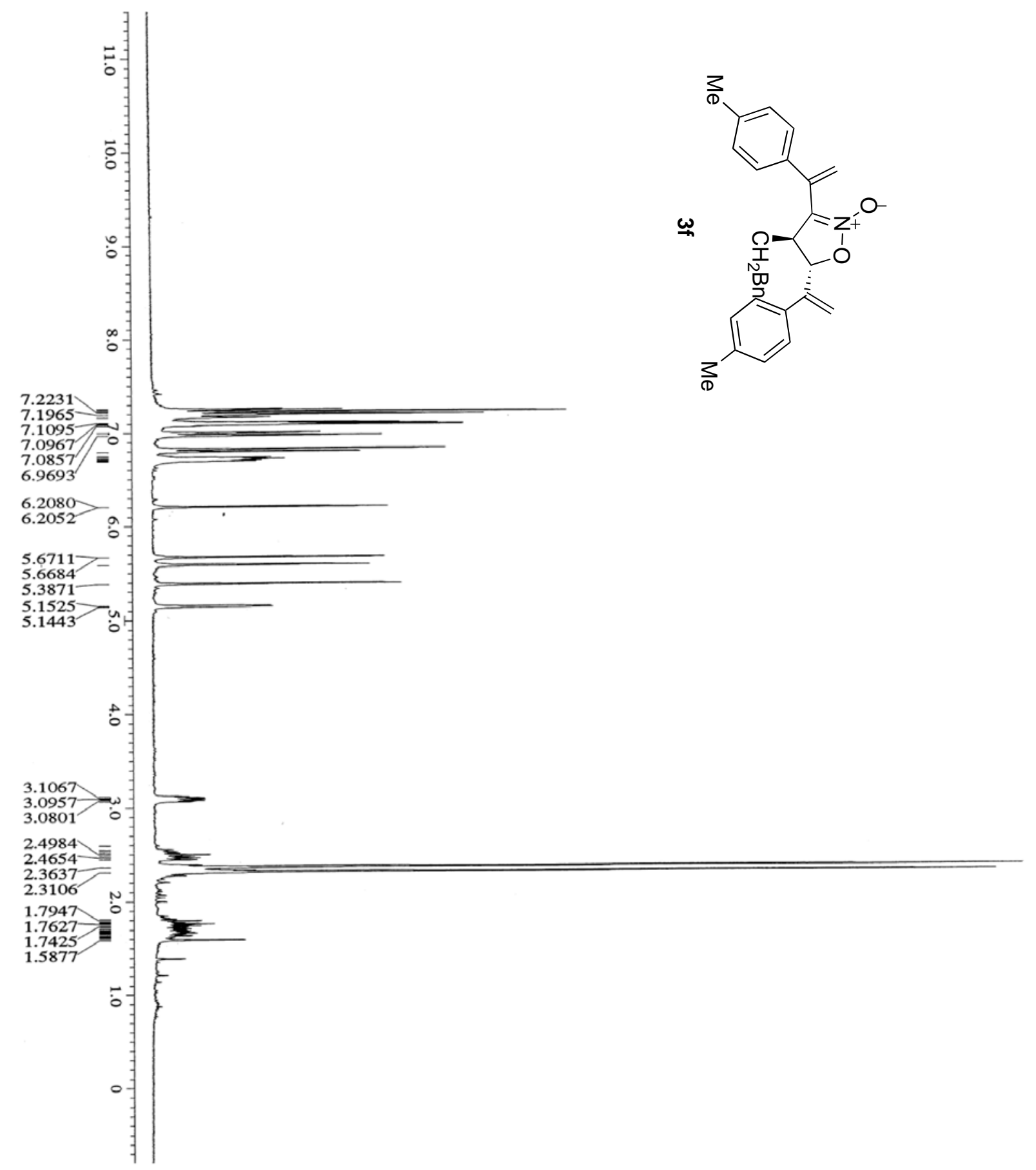




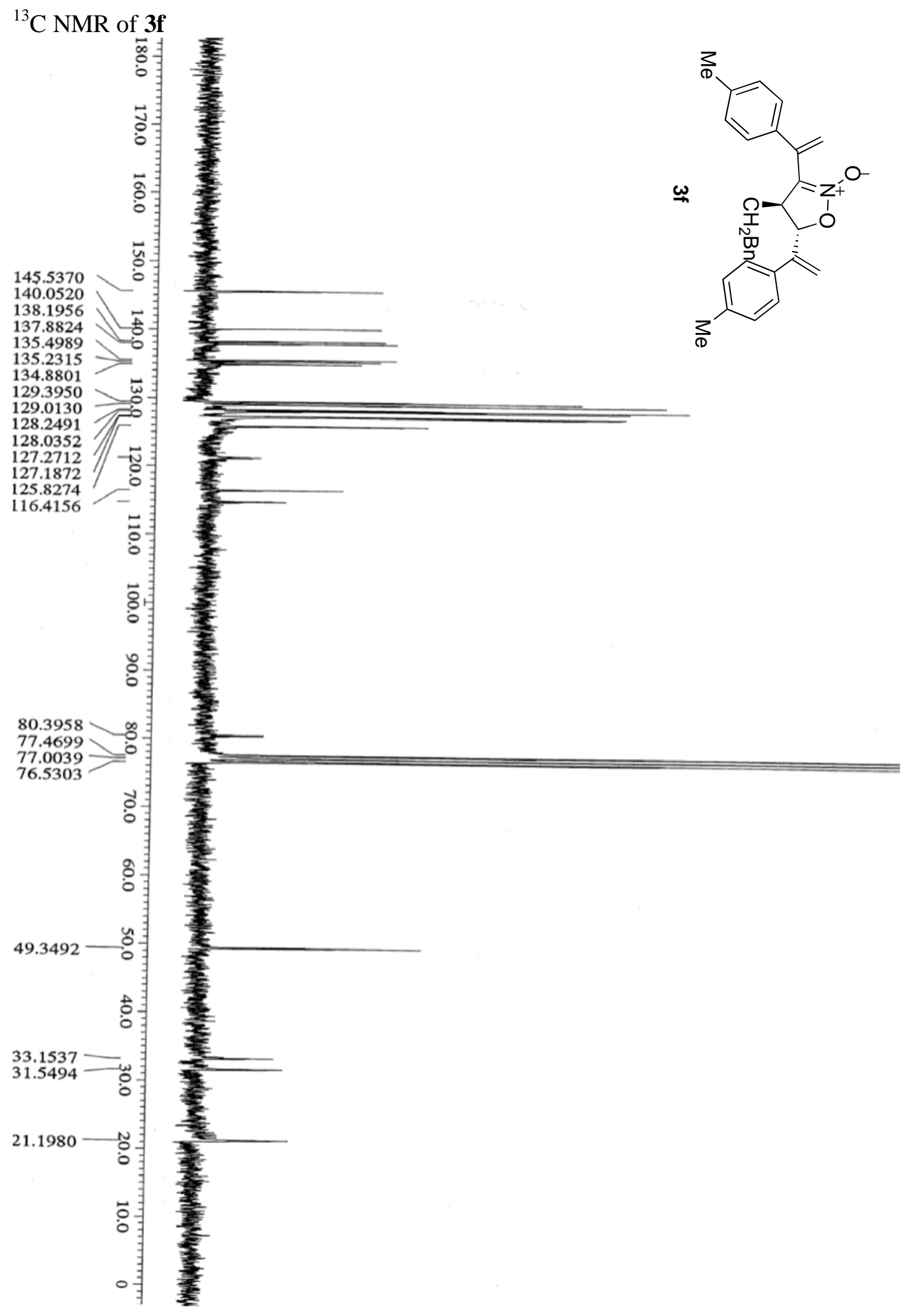




\section{${ }^{1} \mathrm{H}$ NMR of $\mathbf{3 g}$}

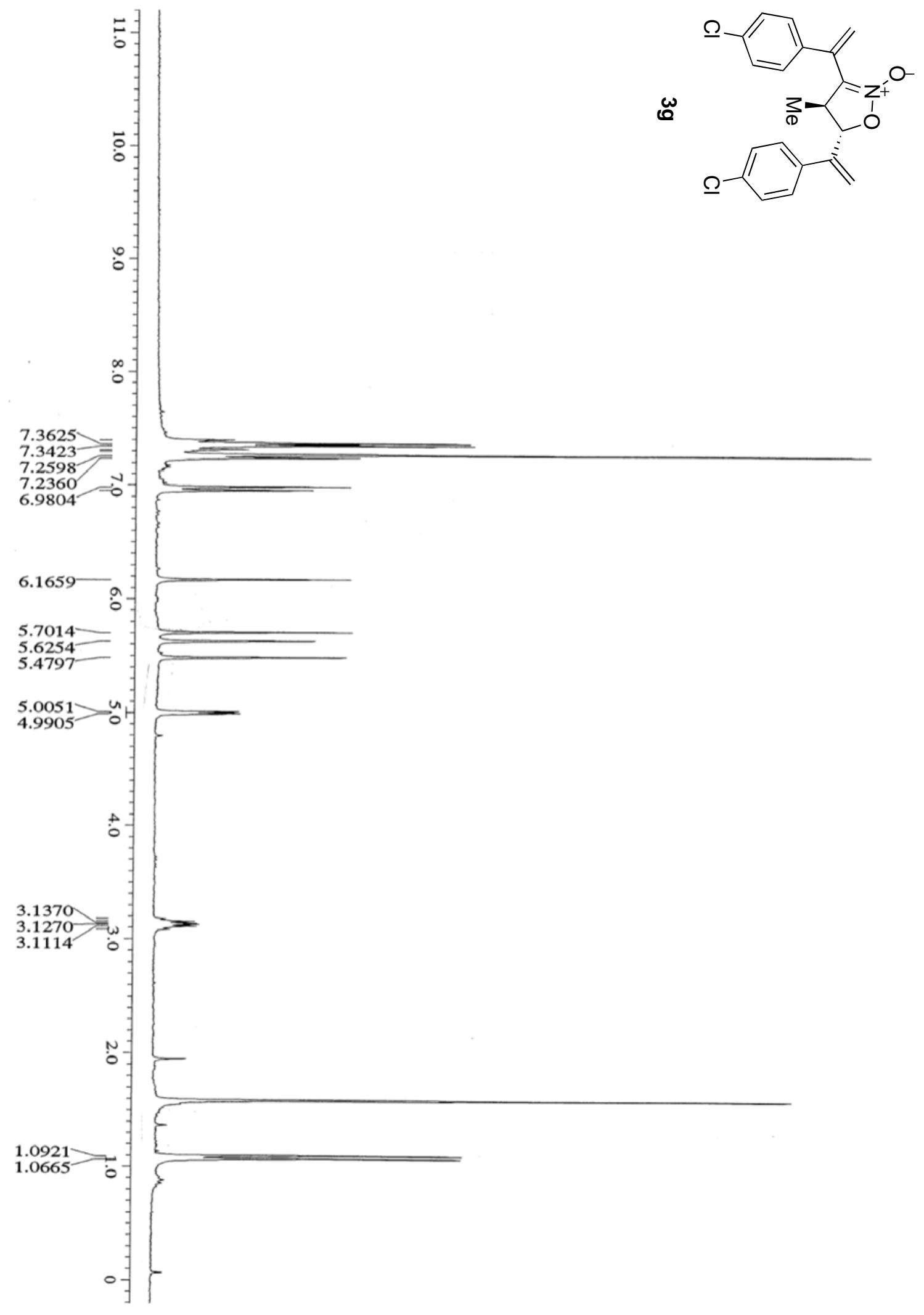




$$
E^{*}
$$




\section{${ }^{1} \mathrm{H}$ NMR of $\mathbf{3 h}$}

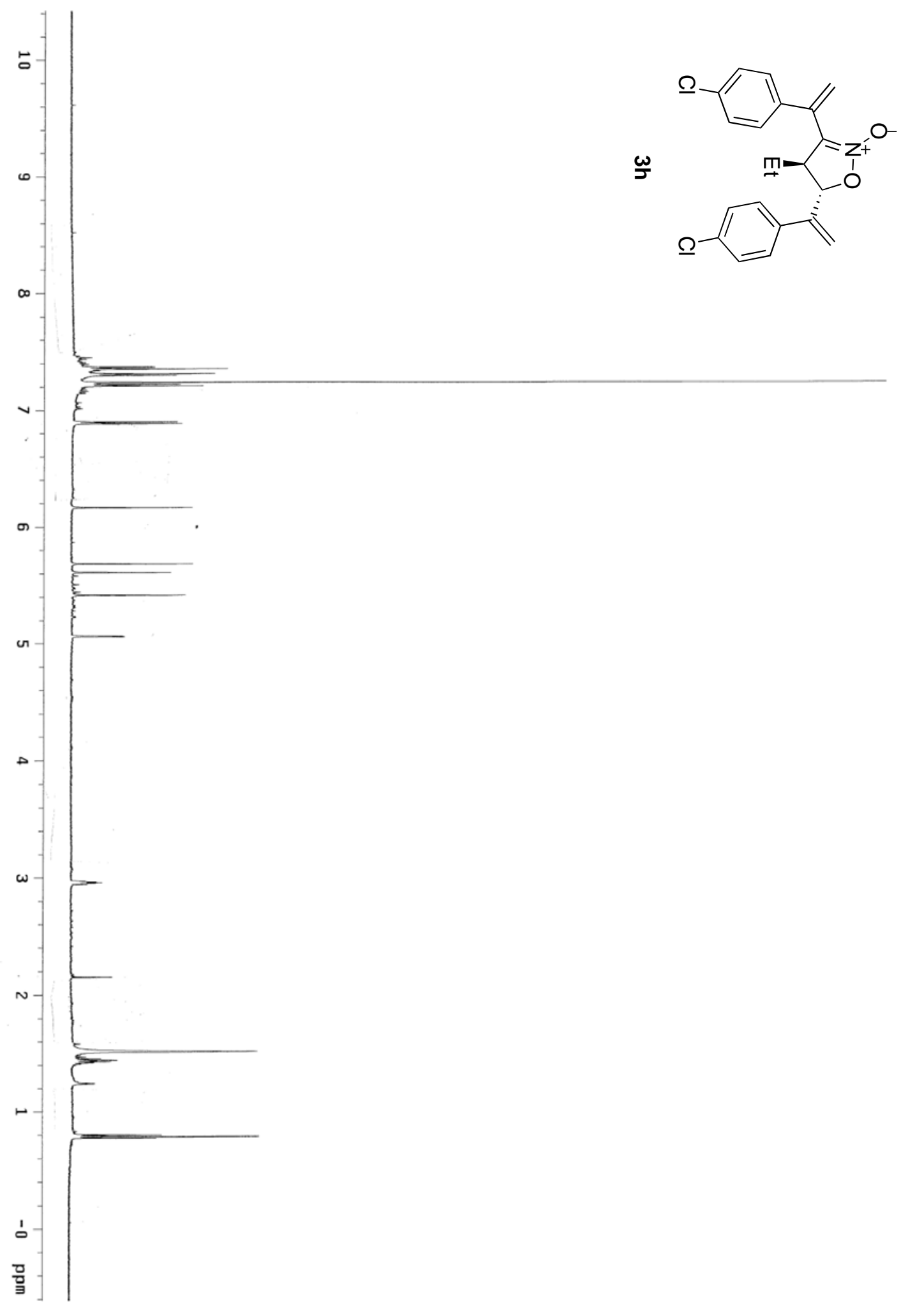




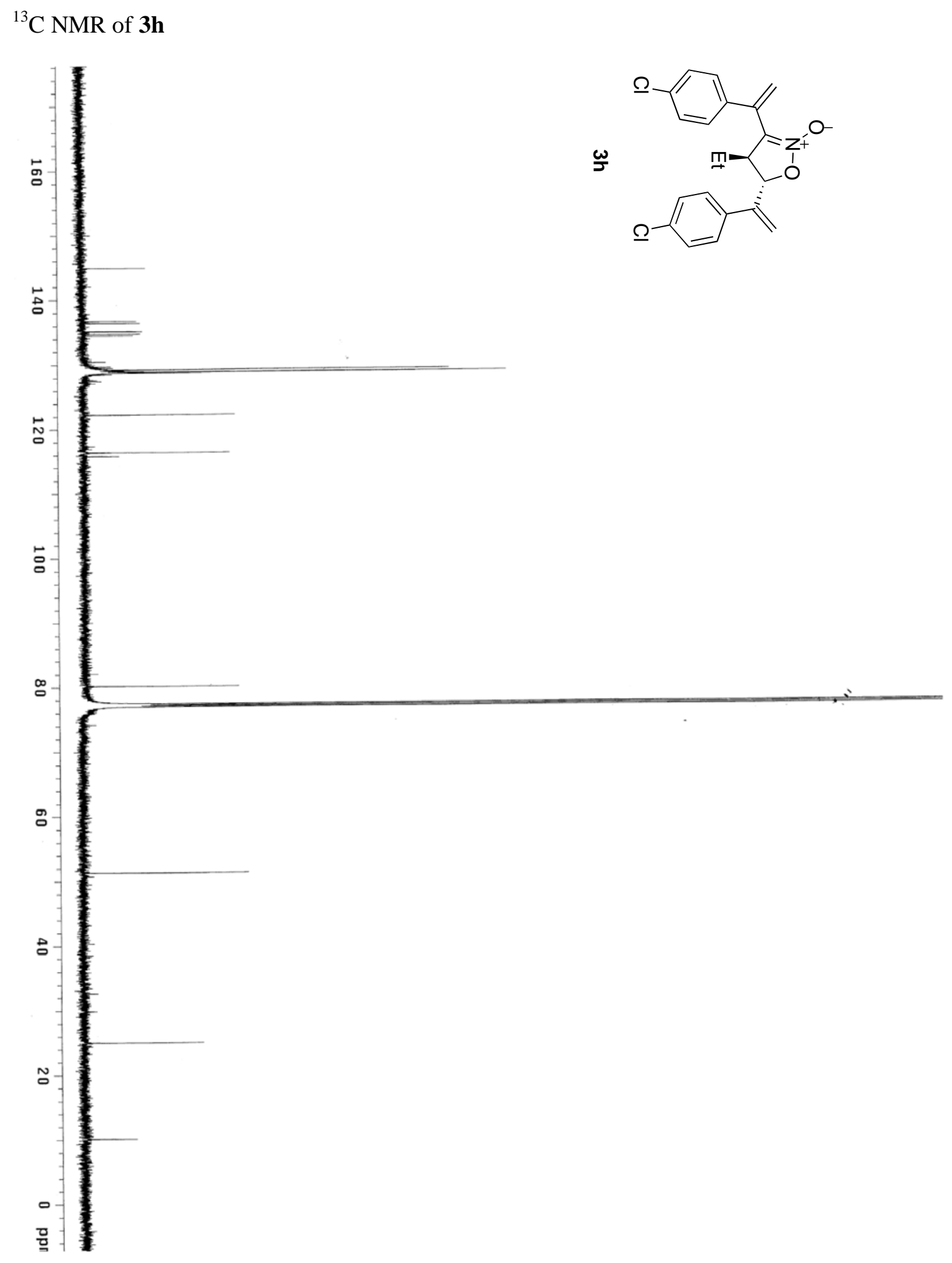




\section{${ }^{1} \mathrm{H}$ NMR of $3 \mathbf{i}$}

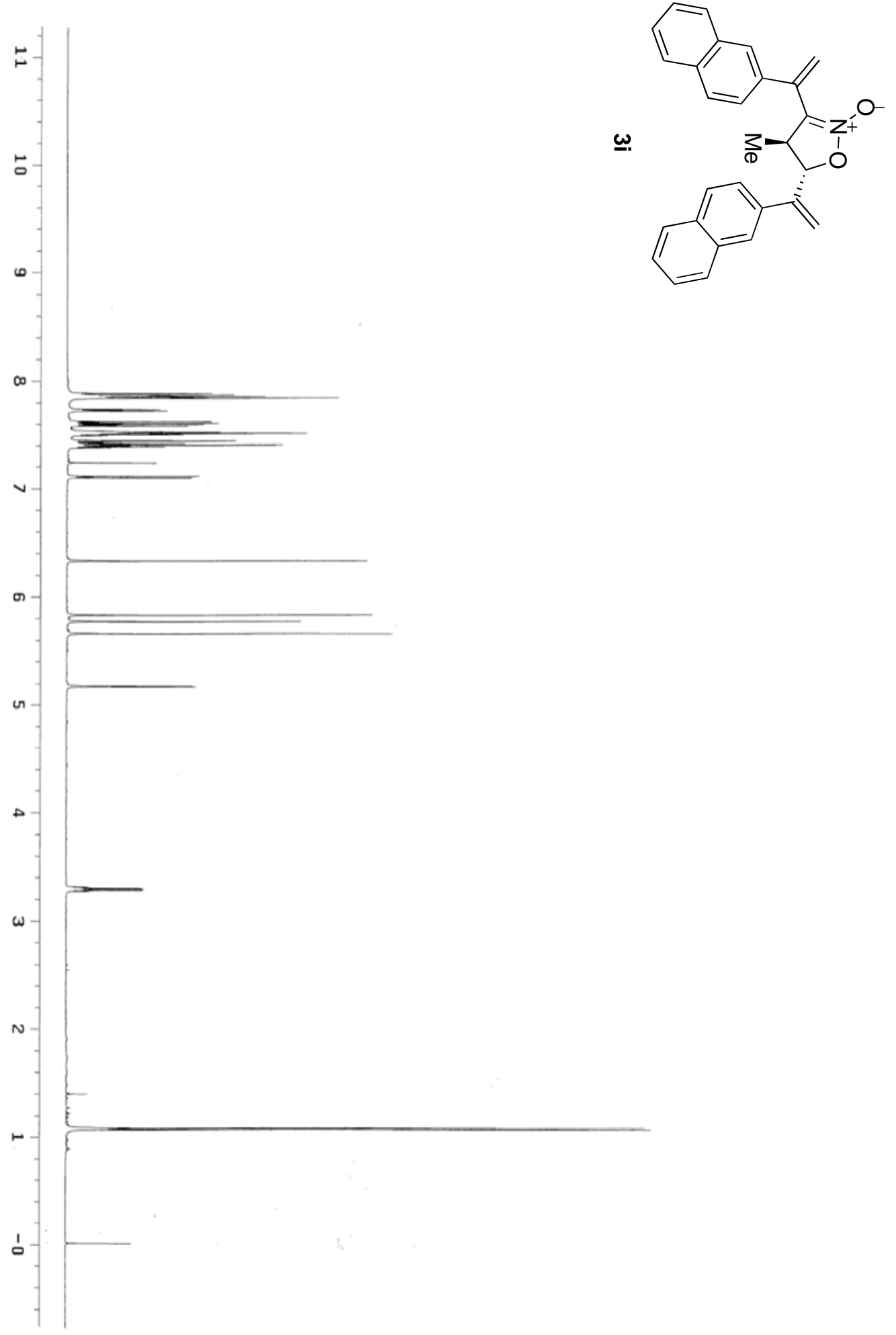


${ }^{13} \mathrm{C}$ NMR of 3i

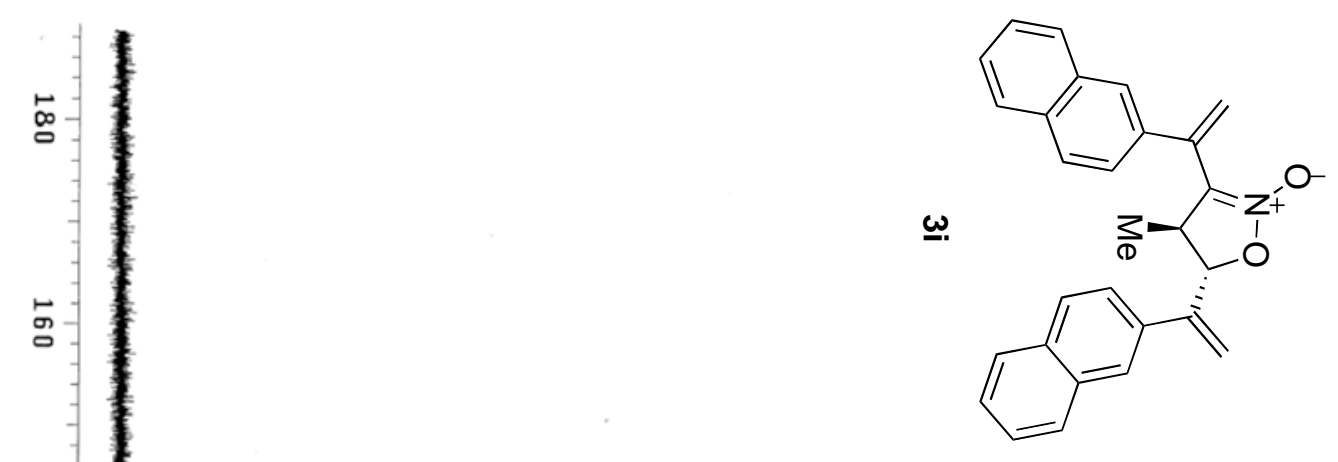

s

点.

N

N-

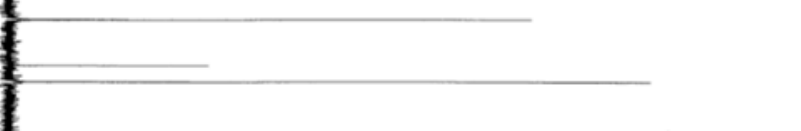

曲

$\stackrel{\infty}{\circ-1}$

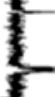

$8-$

.

$\longdiv { 1 0 }$

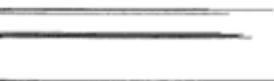

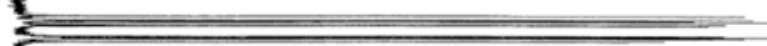

吕.

ก

.

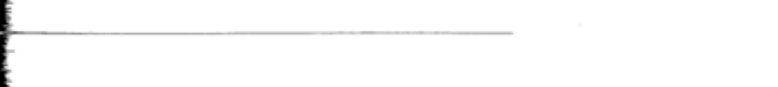

$\circ-$

뭅 


\section{${ }^{1} \mathrm{H}$ NMR of $\mathbf{3 j}$}

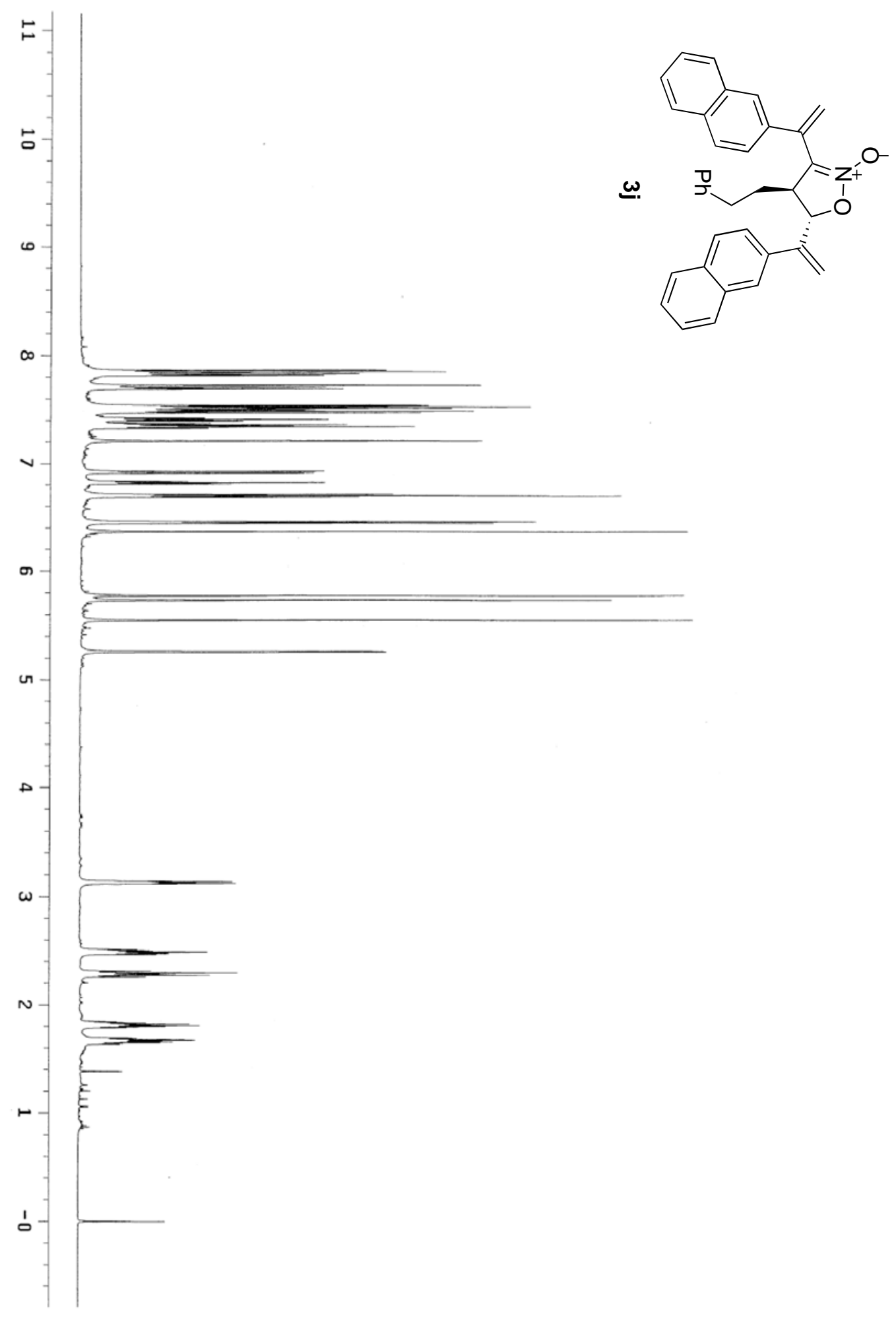


${ }^{13} \mathrm{C}$ NMR of $3 \mathbf{j}$

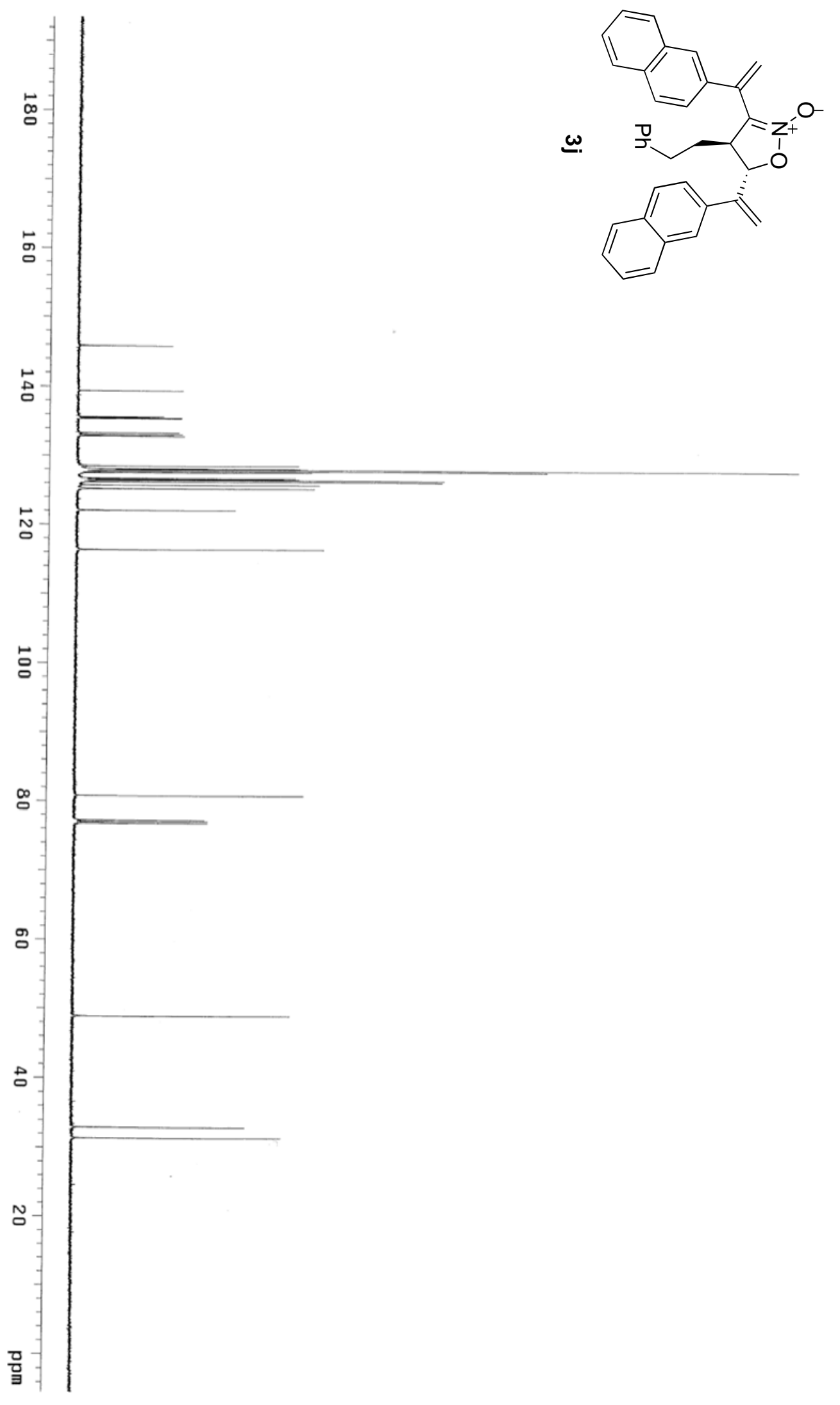




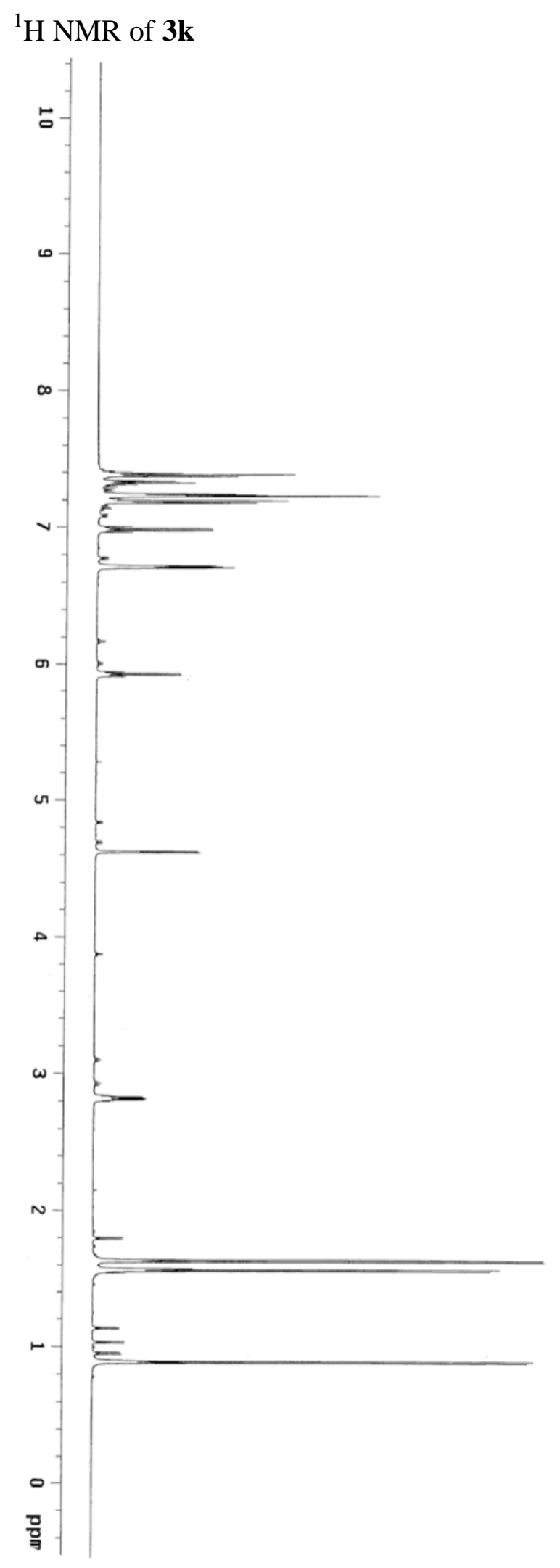


${ }^{13} \mathrm{C}$ NMR of $3 \mathbf{k}$

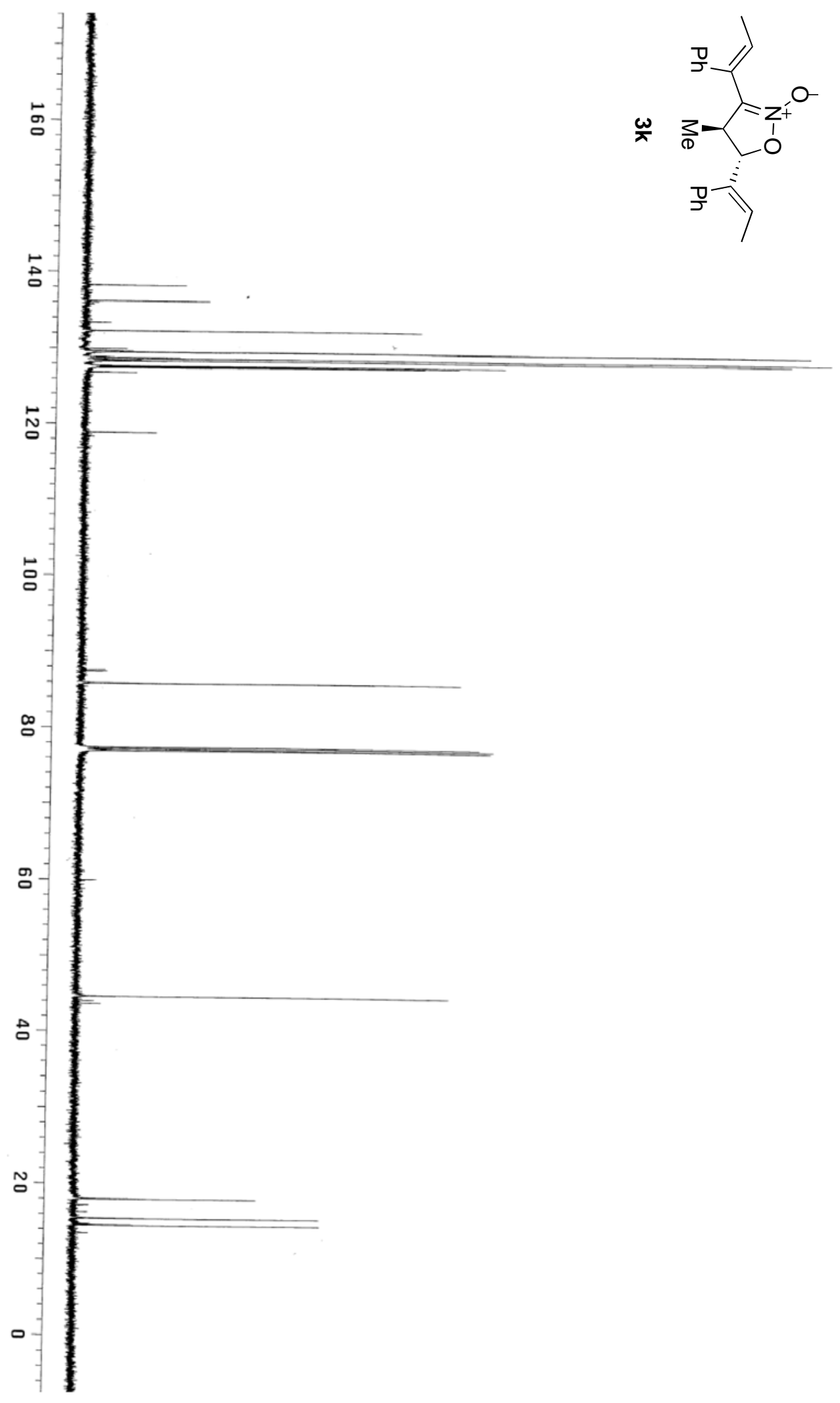

87 


\section{${ }^{1}$ H NMR of 3 l}

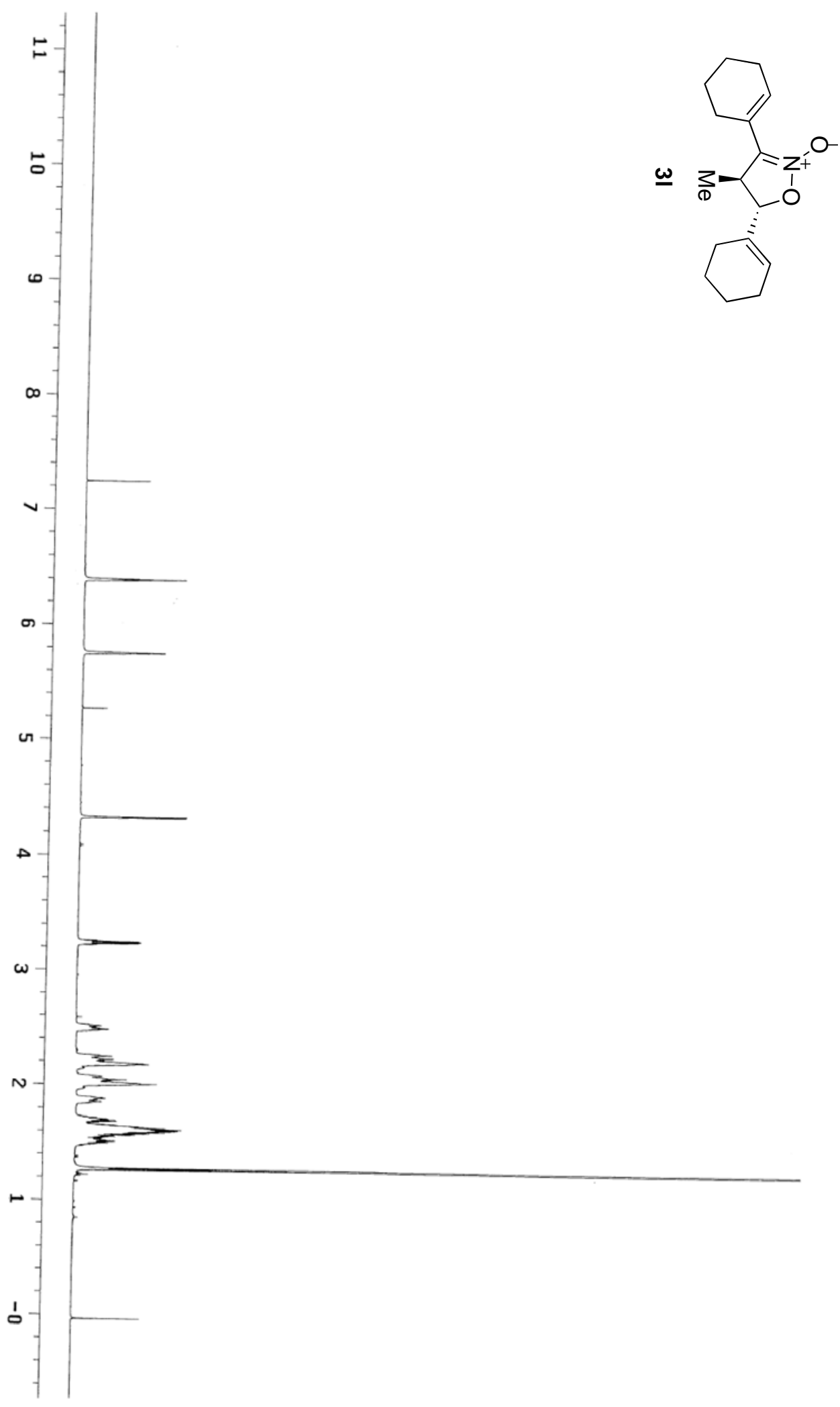


${ }^{13} \mathrm{C}$ NMR of 31

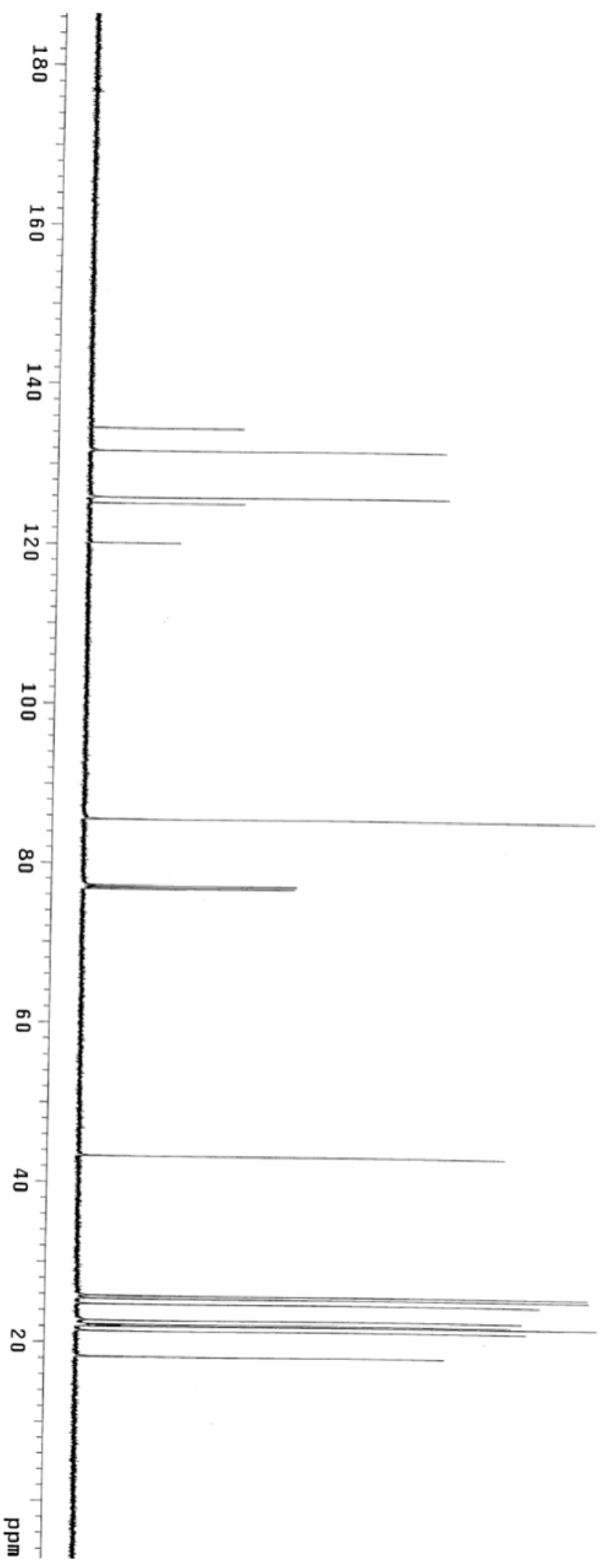




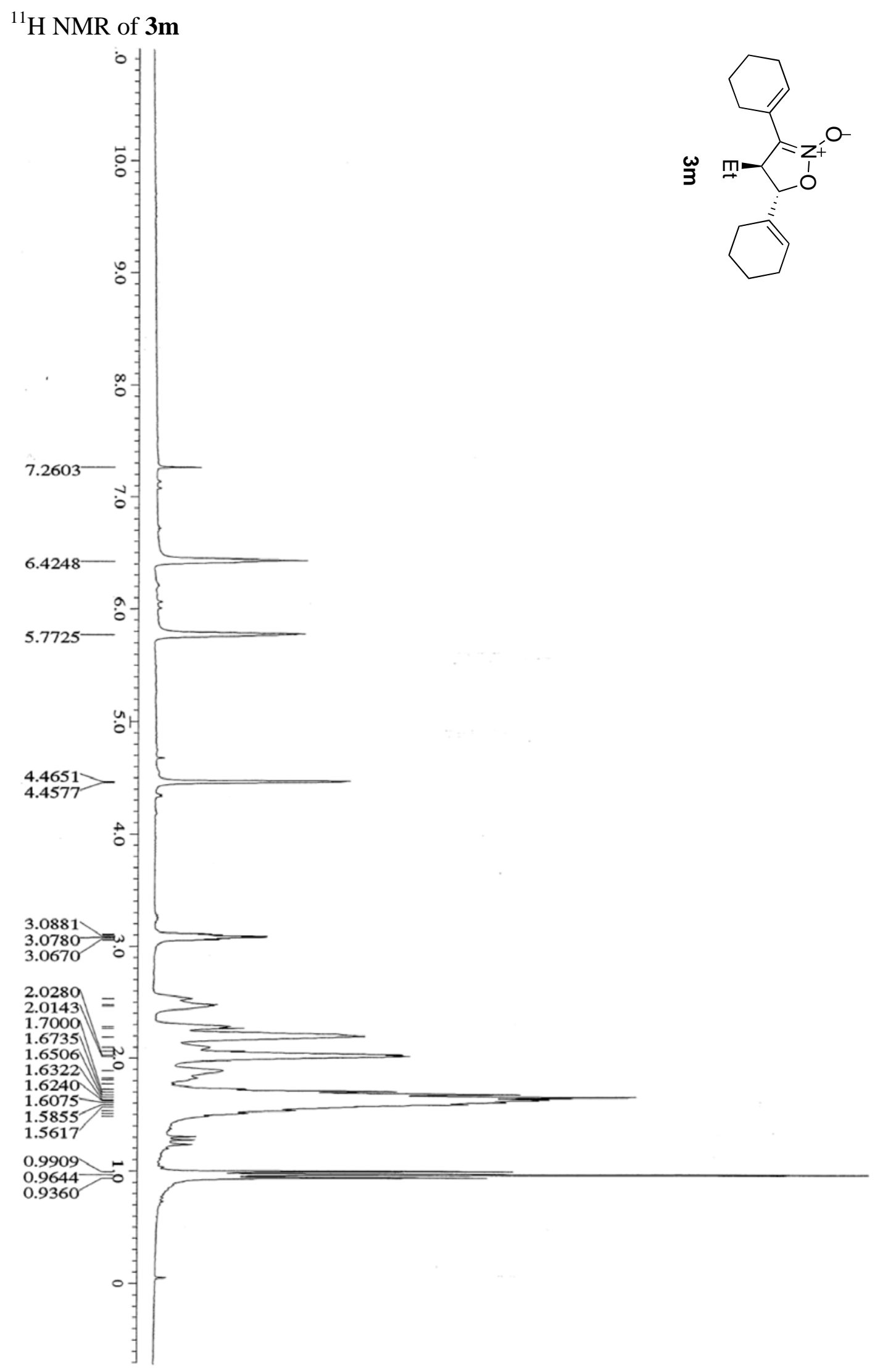




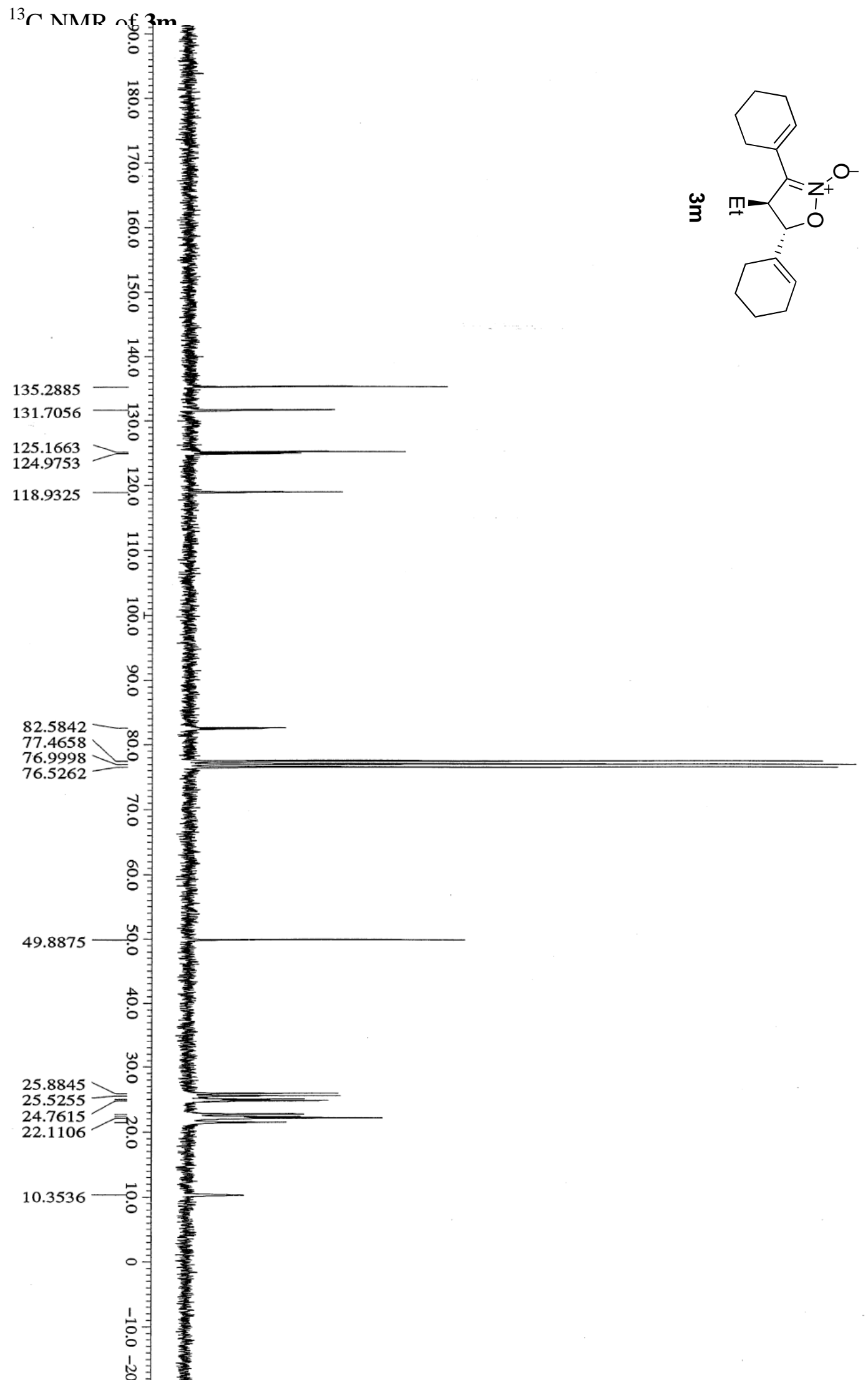




\section{${ }^{1} \mathrm{H}$ NMR of $3 \mathbf{n}$}

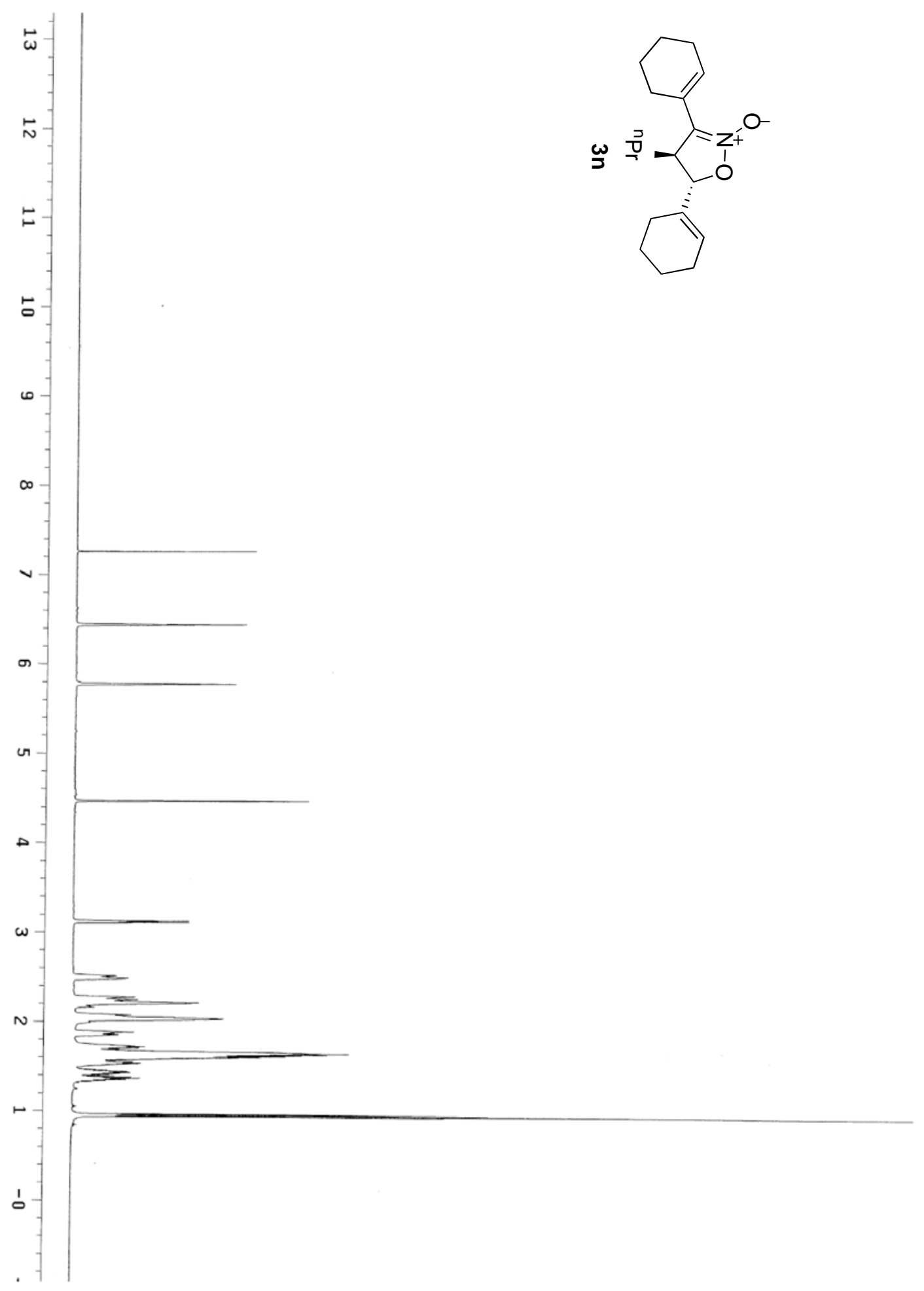




$$
\text { it }
$$



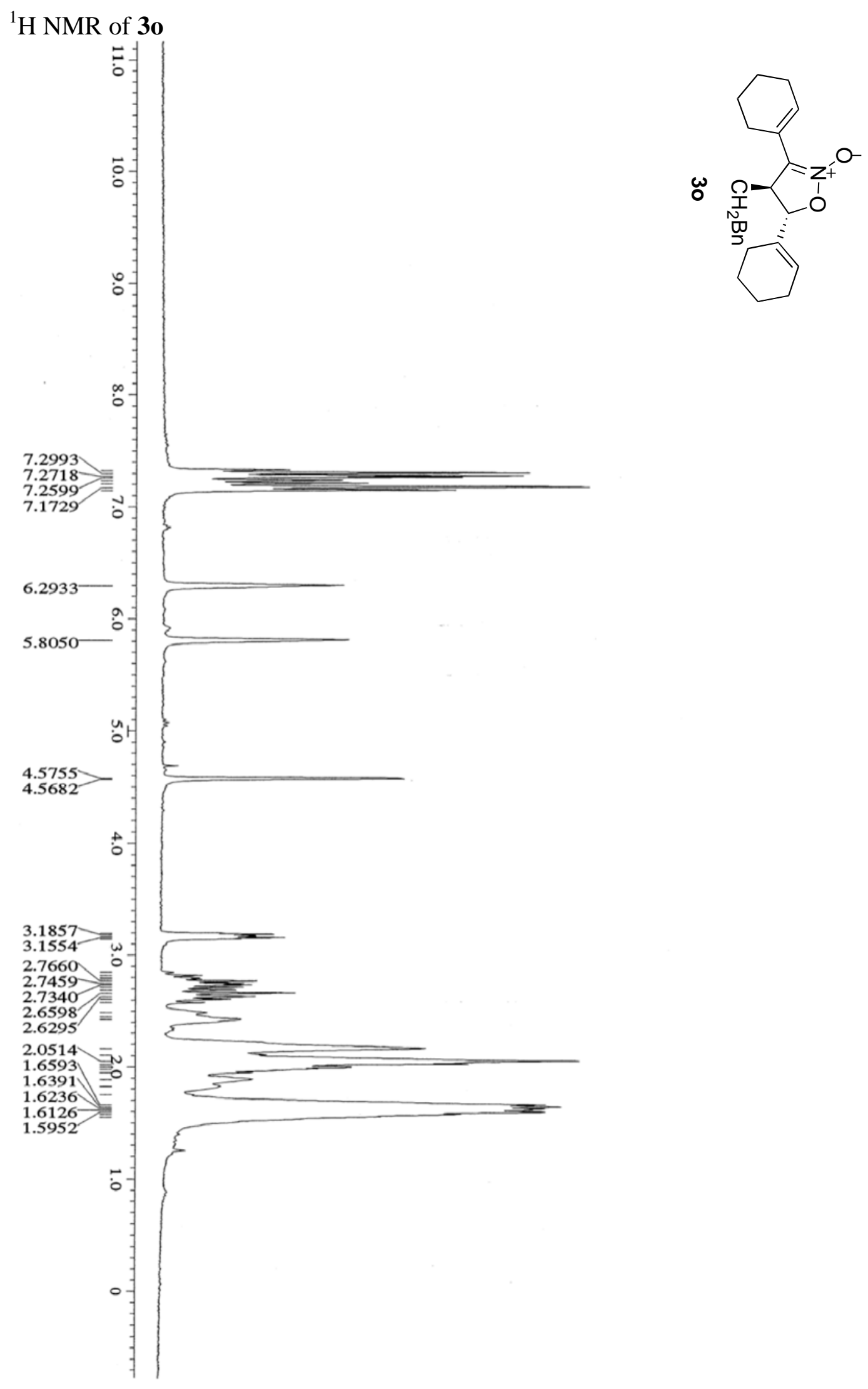


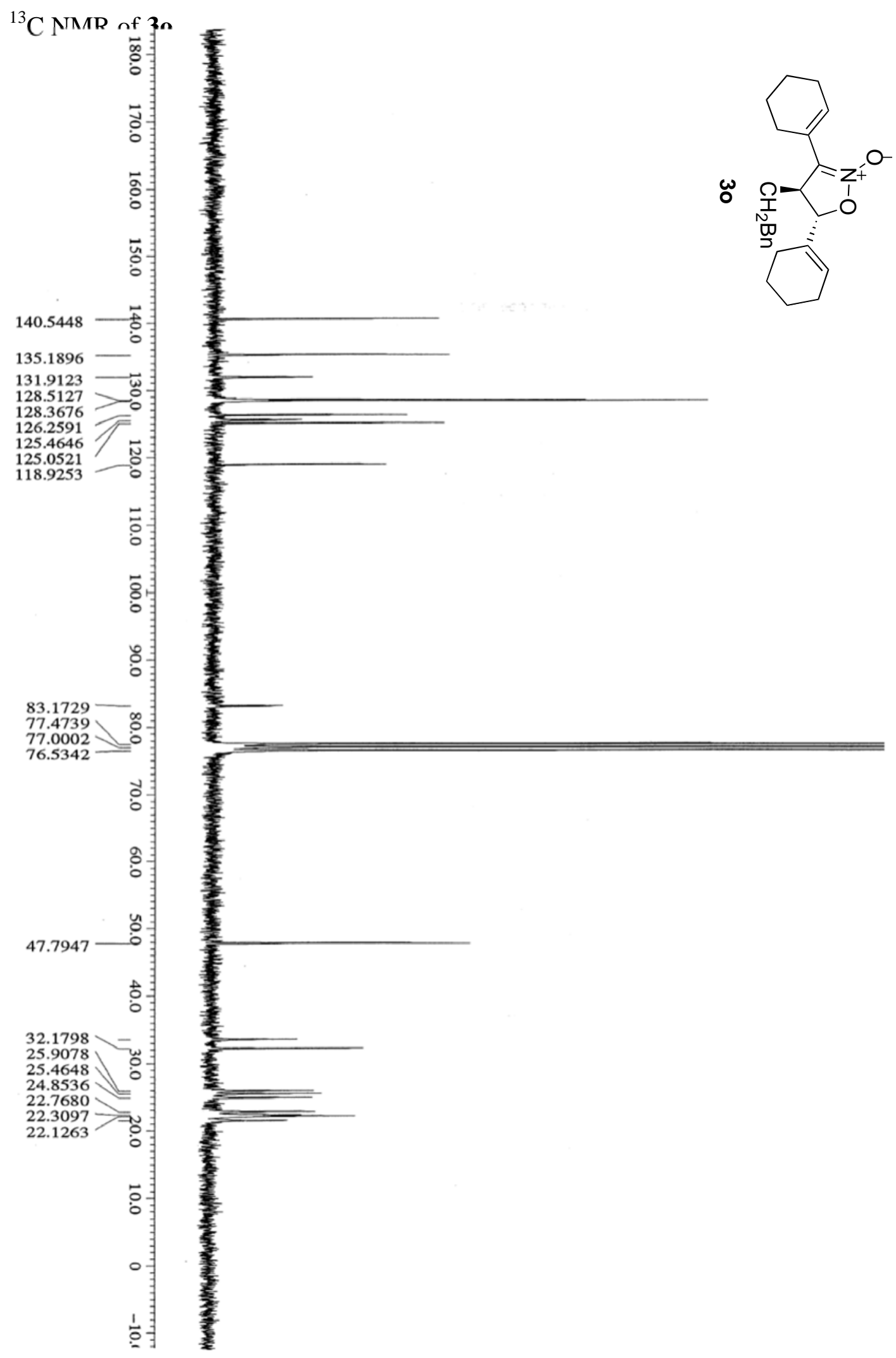


${ }^{1} \mathrm{H}$ NMR of $\mathbf{3 p}$

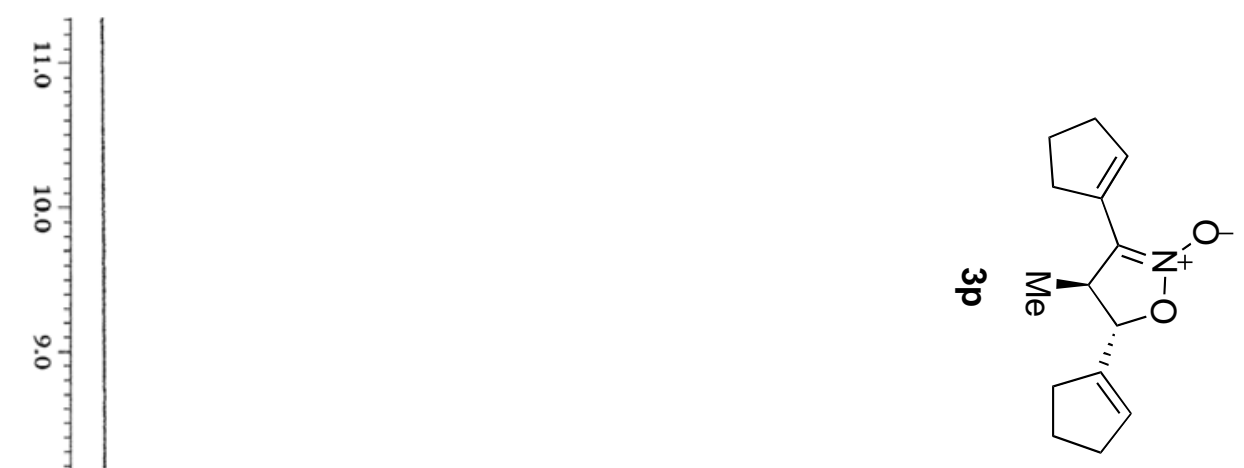

96 


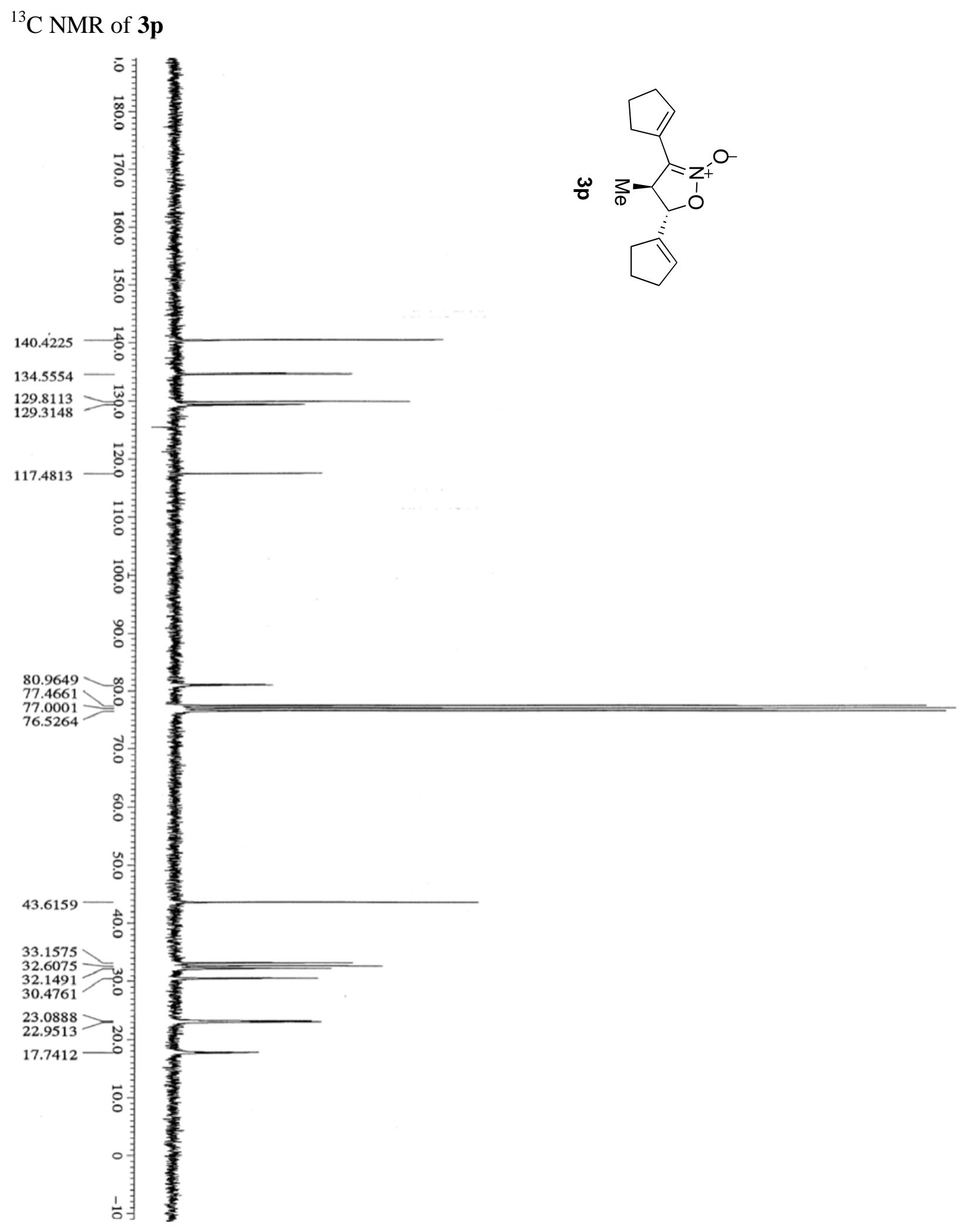




\section{${ }^{1}$ H NMR of $\mathbf{3 q}$}

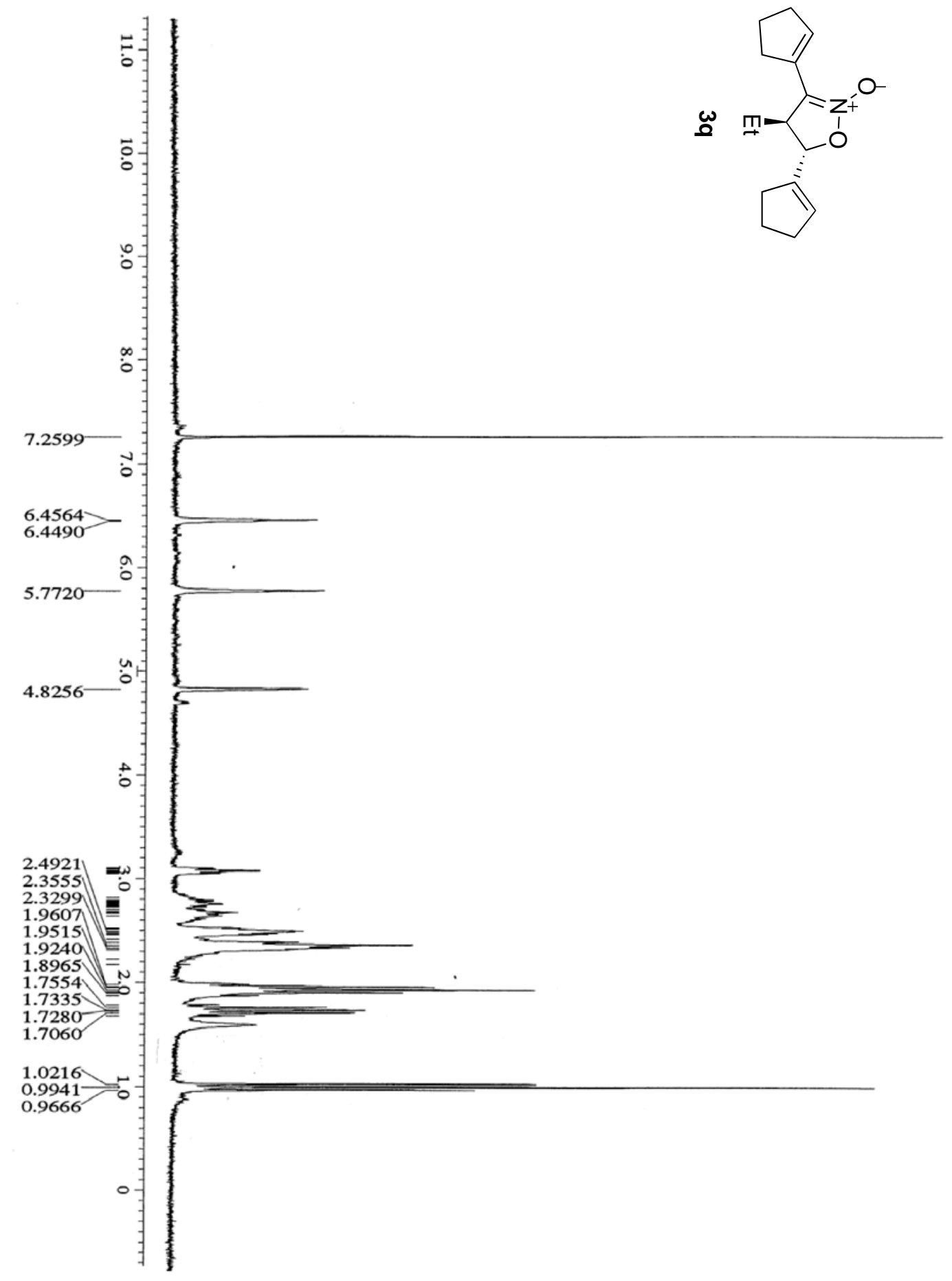


${ }^{13} \mathrm{C}$ NMR of $\mathbf{3 q}$

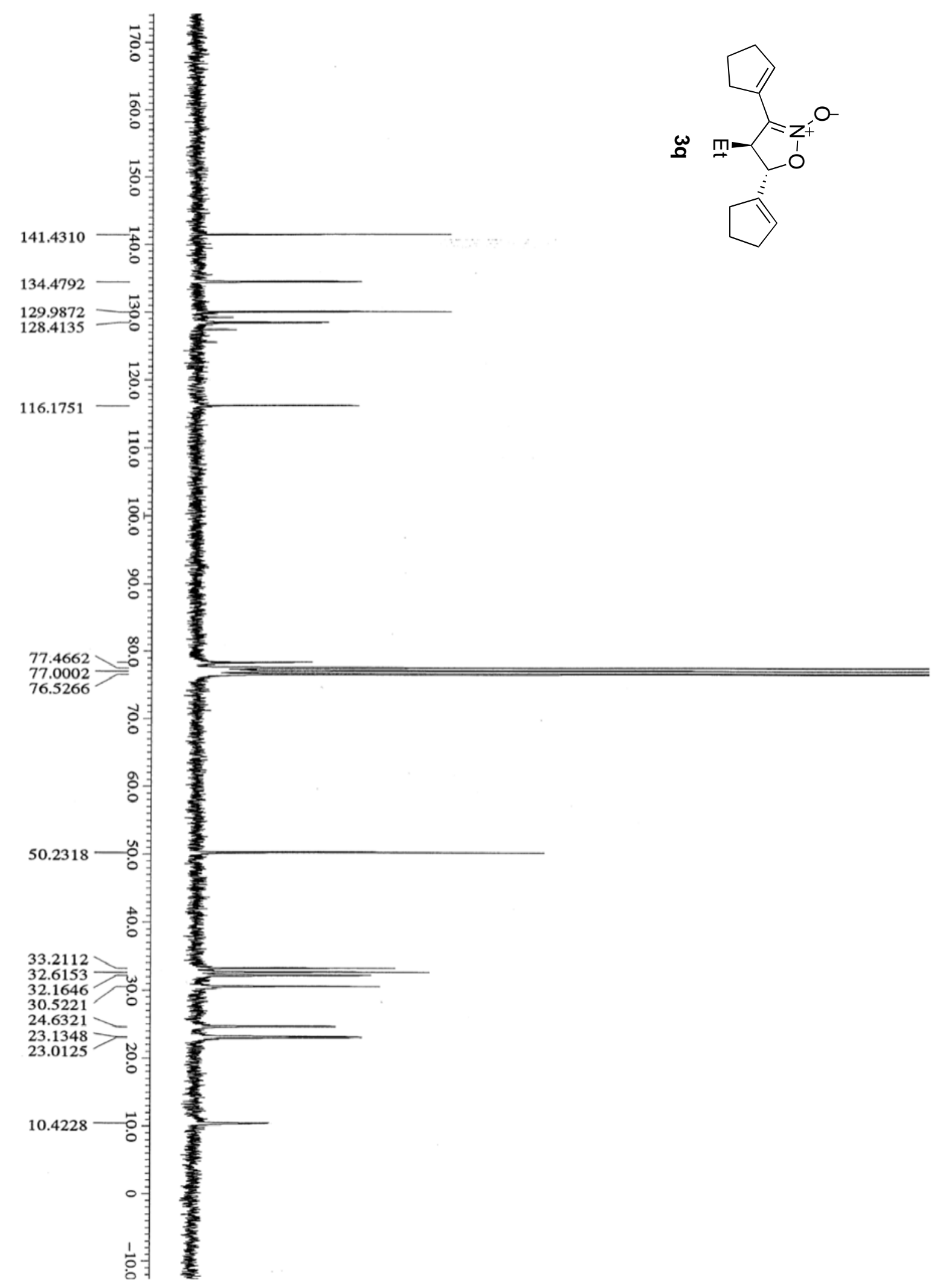

99 


\section{${ }^{1} \mathrm{H}$ NMR of $3 r$}

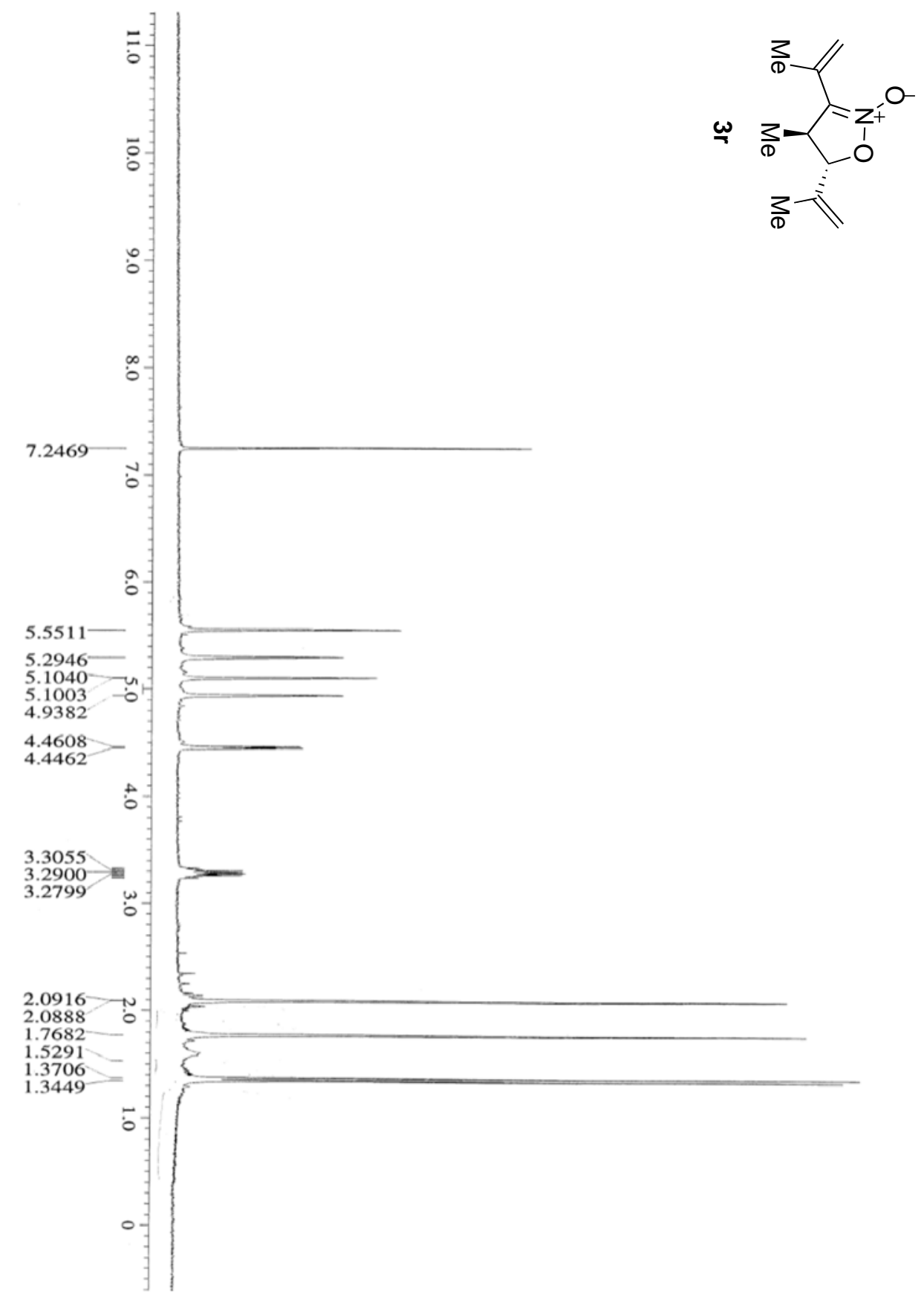




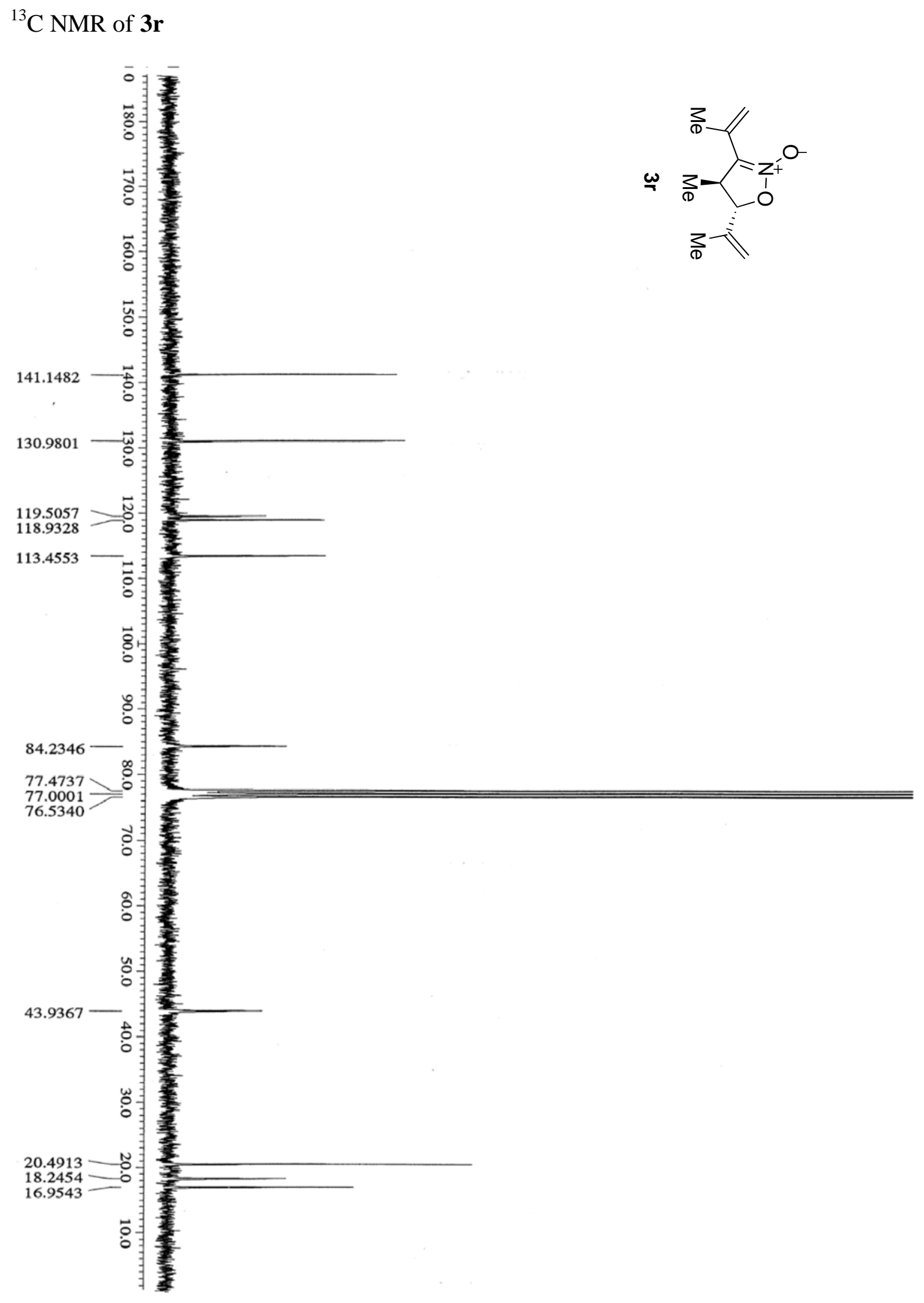




\section{${ }^{1} \mathrm{H}$ NMR of $5 a$}

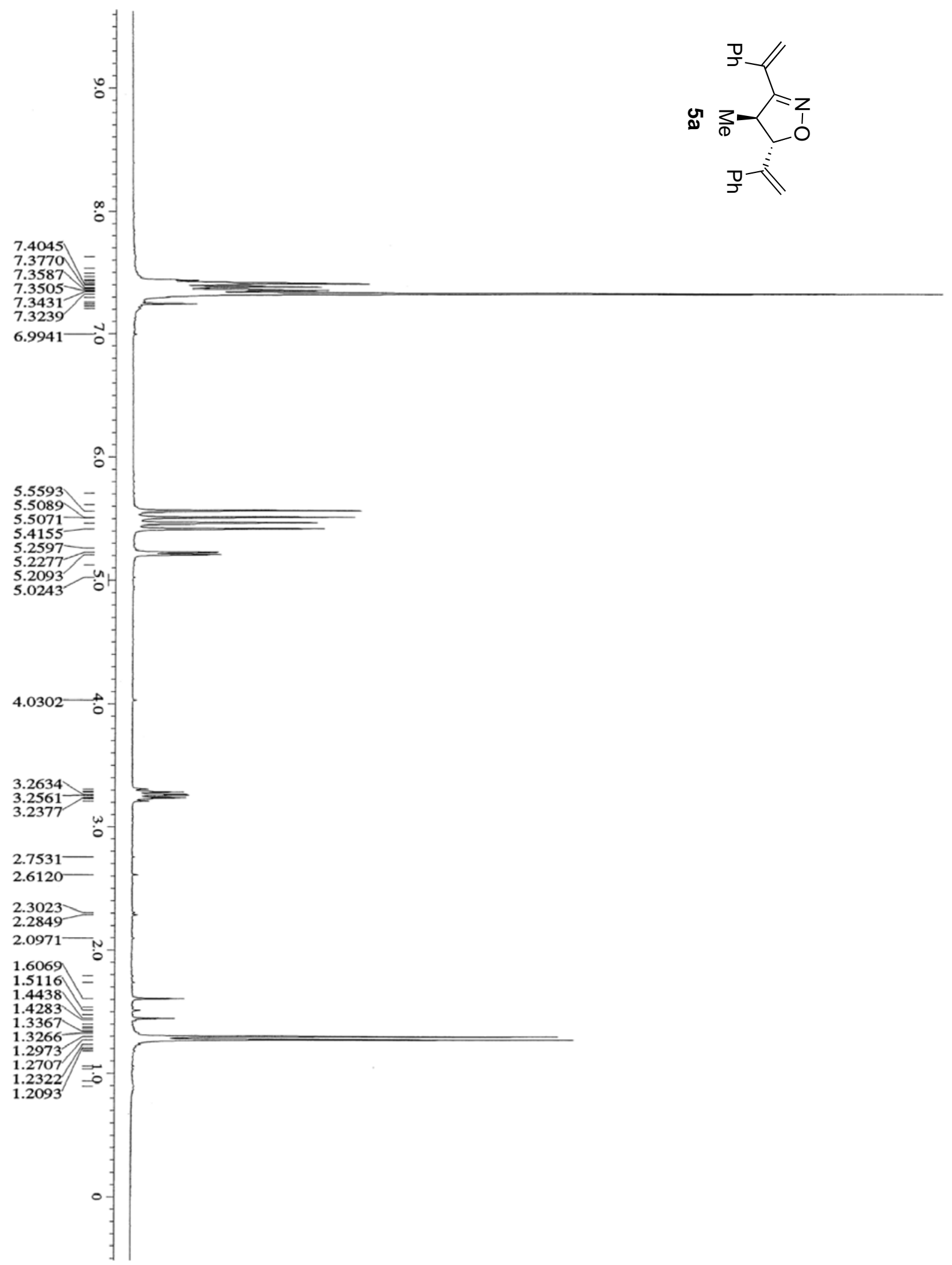




\section{${ }^{13} \mathrm{C}$ NMR of $5 a$}

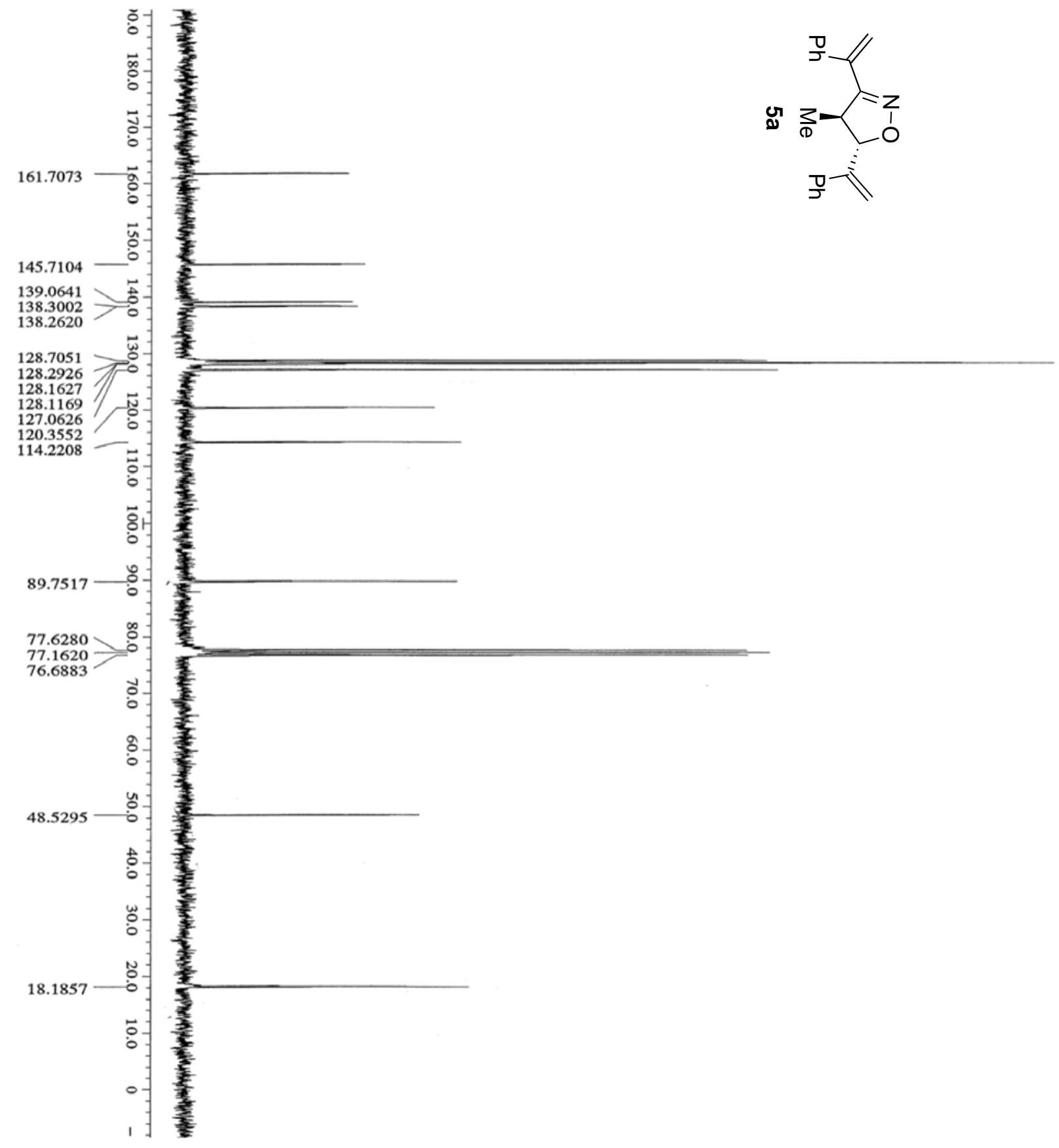




\section{${ }^{1}$ H NMR of $\mathbf{5 b}$}

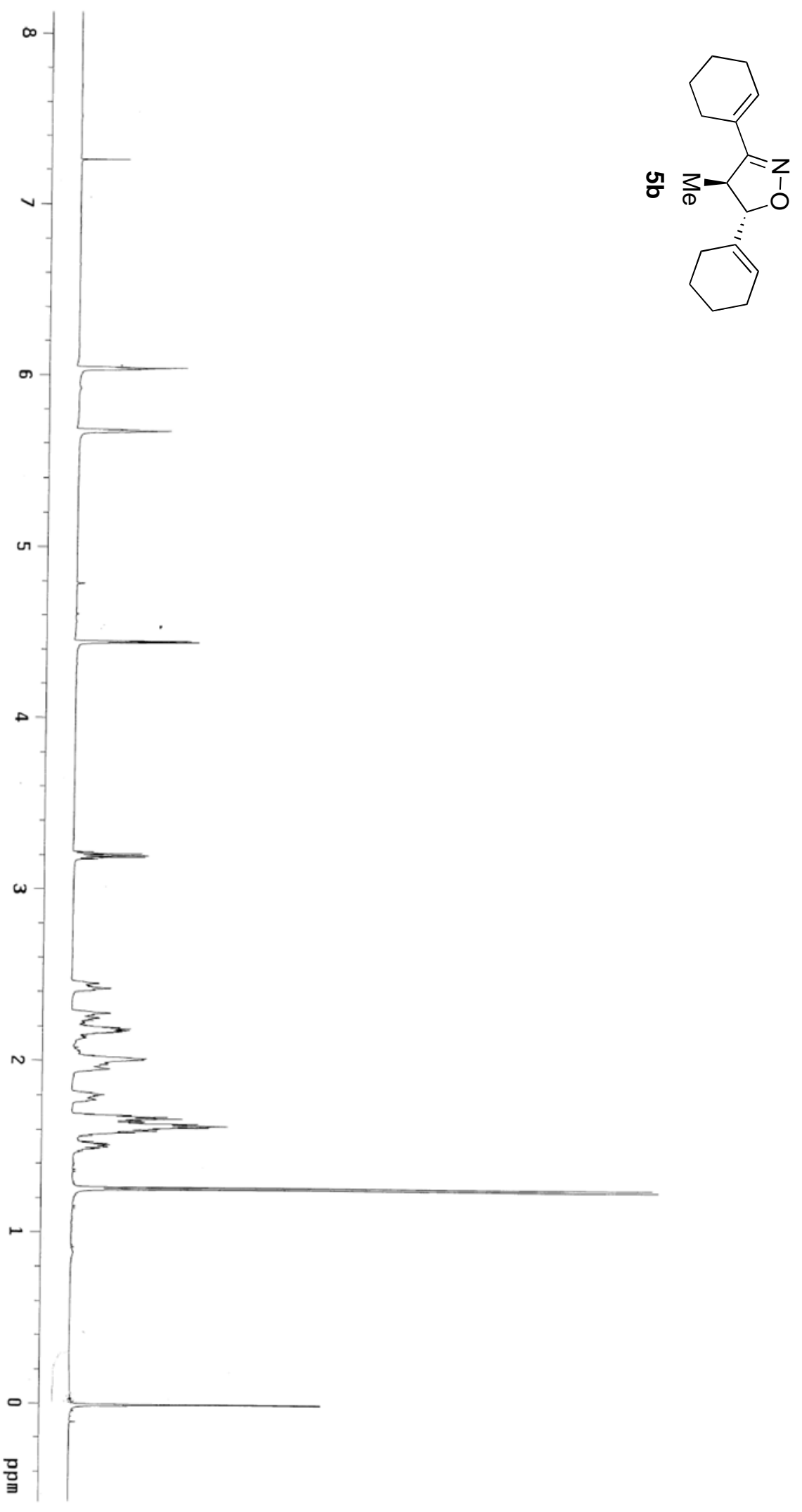




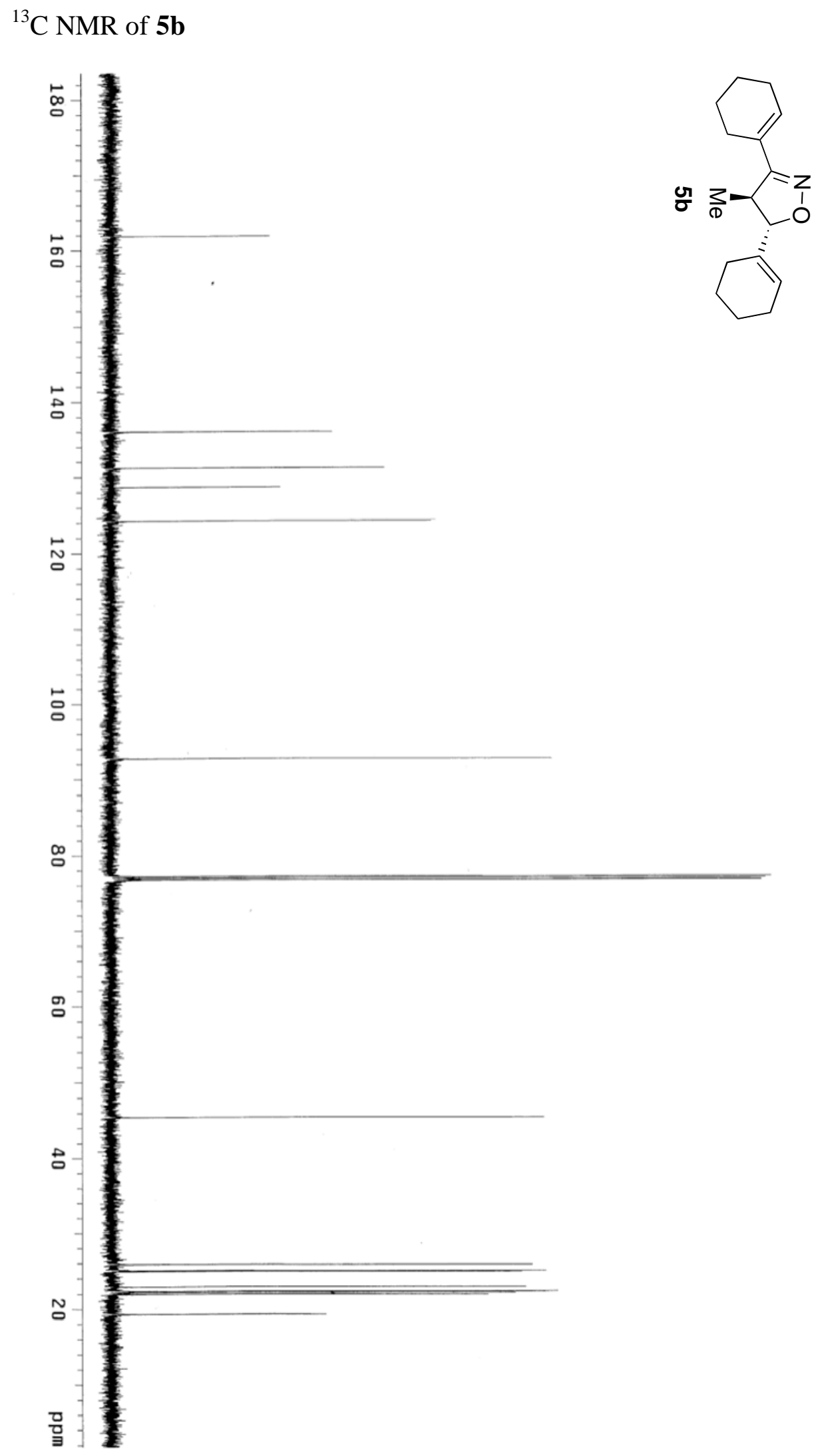




\section{${ }^{1} \mathrm{H}$ NMR of $5 c$}

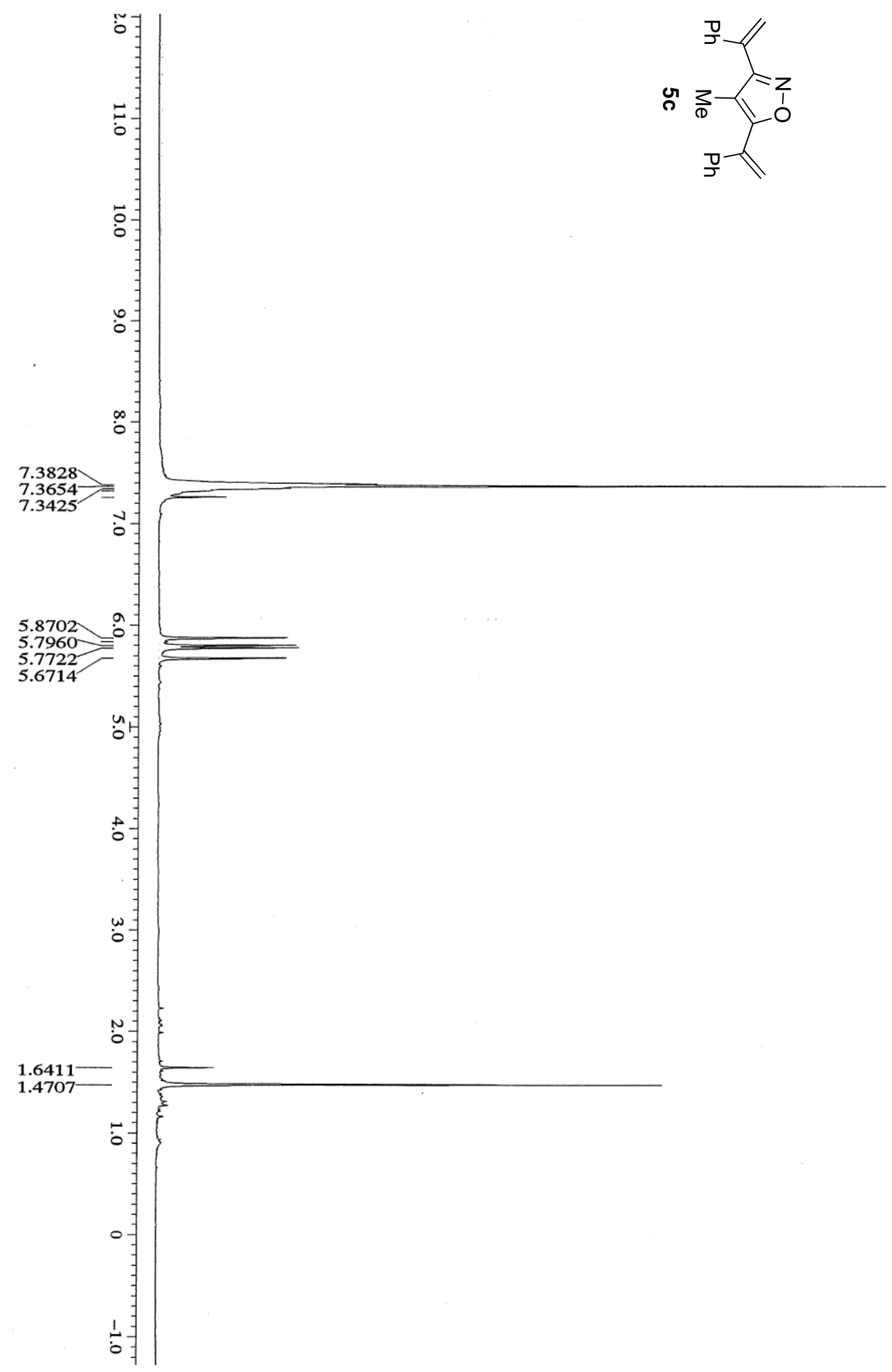




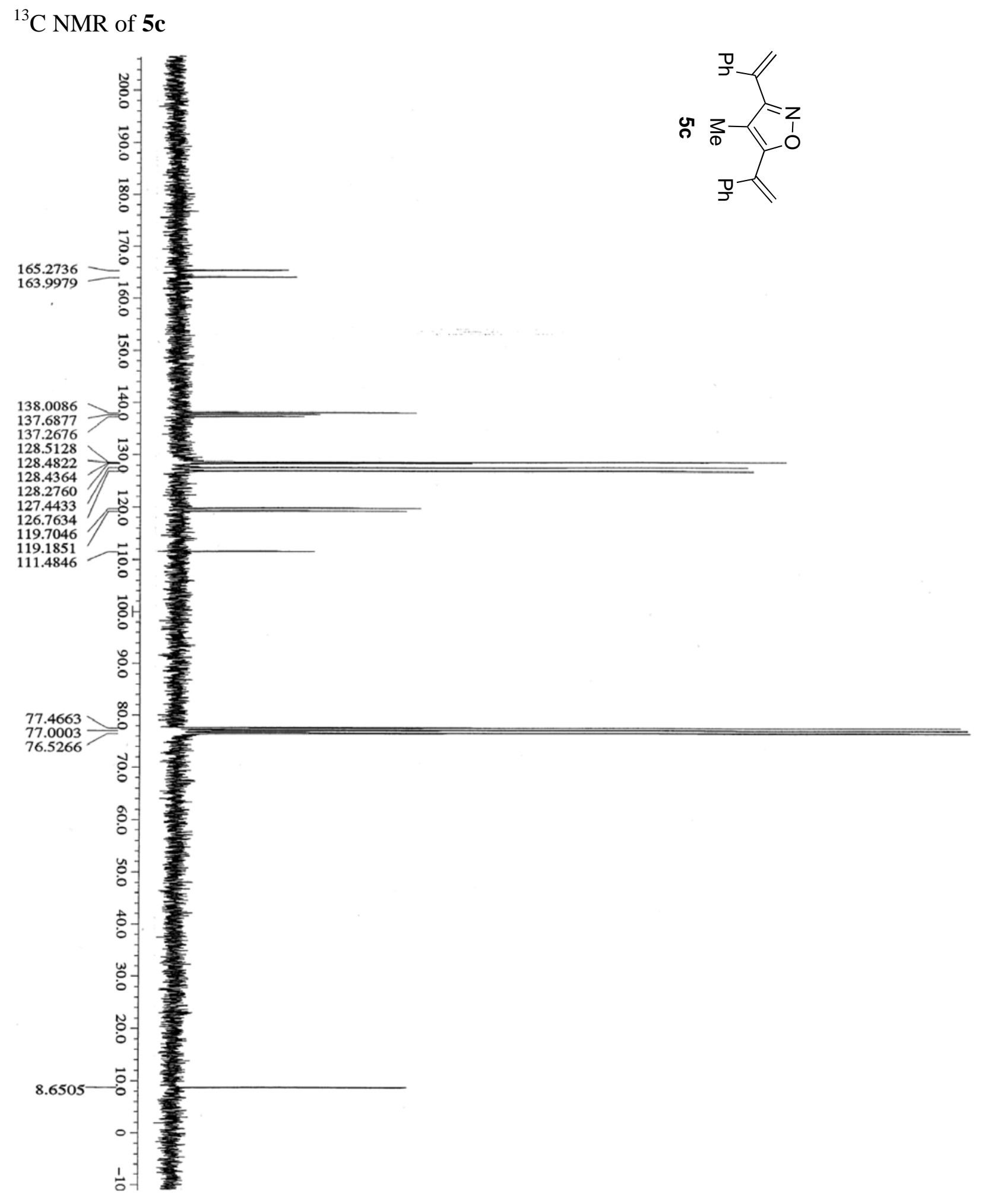




\section{${ }^{1} \mathrm{H}$ NMR of $5 d$}

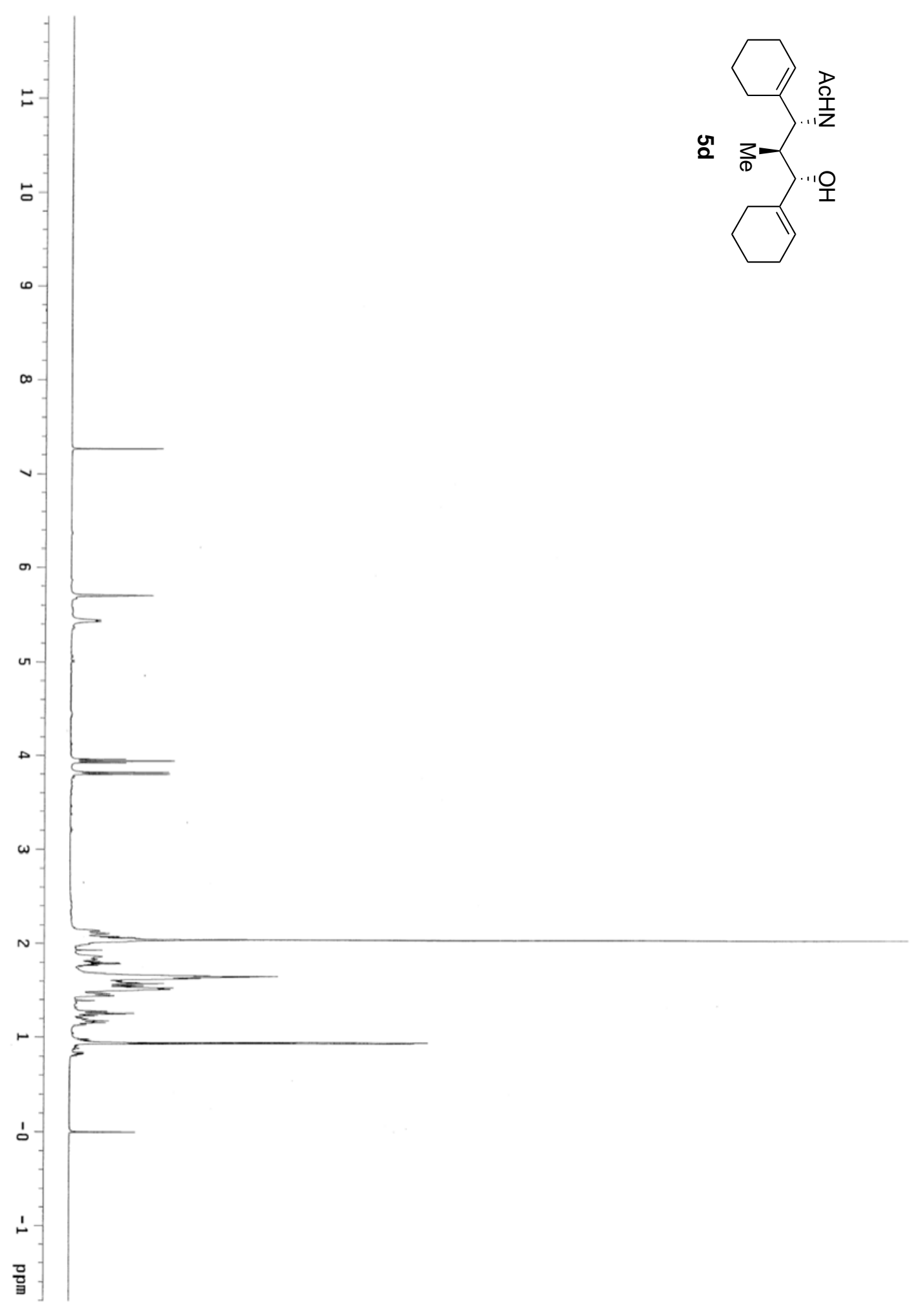


${ }^{13}$ C NMR of 5d

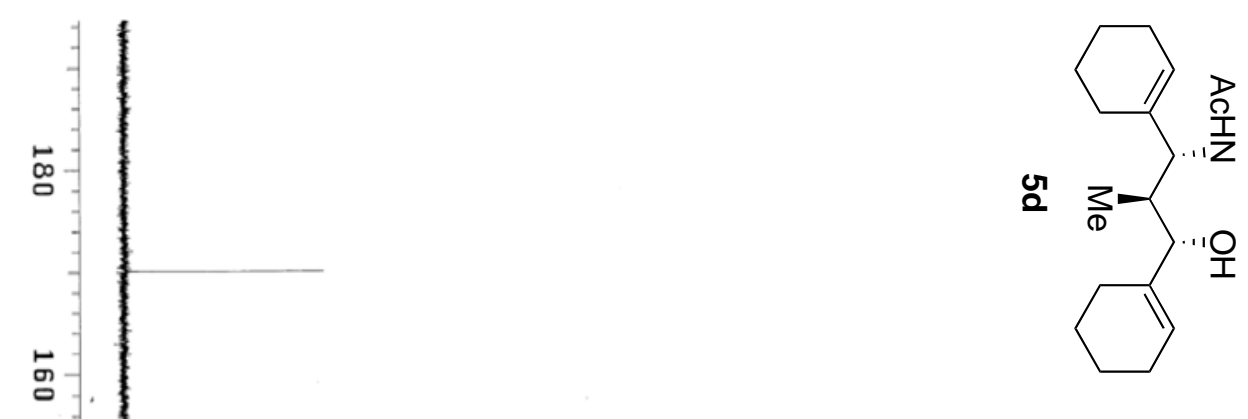

吉

$\stackrel{5}{\circ}$

응

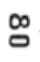

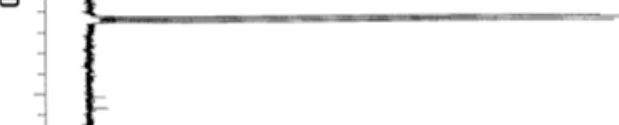

g

D.

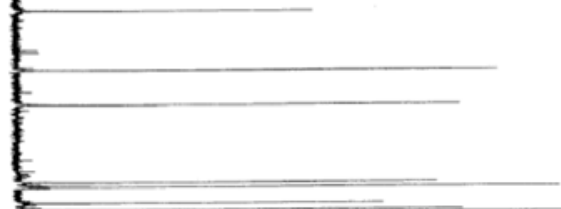

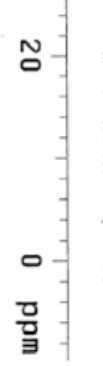




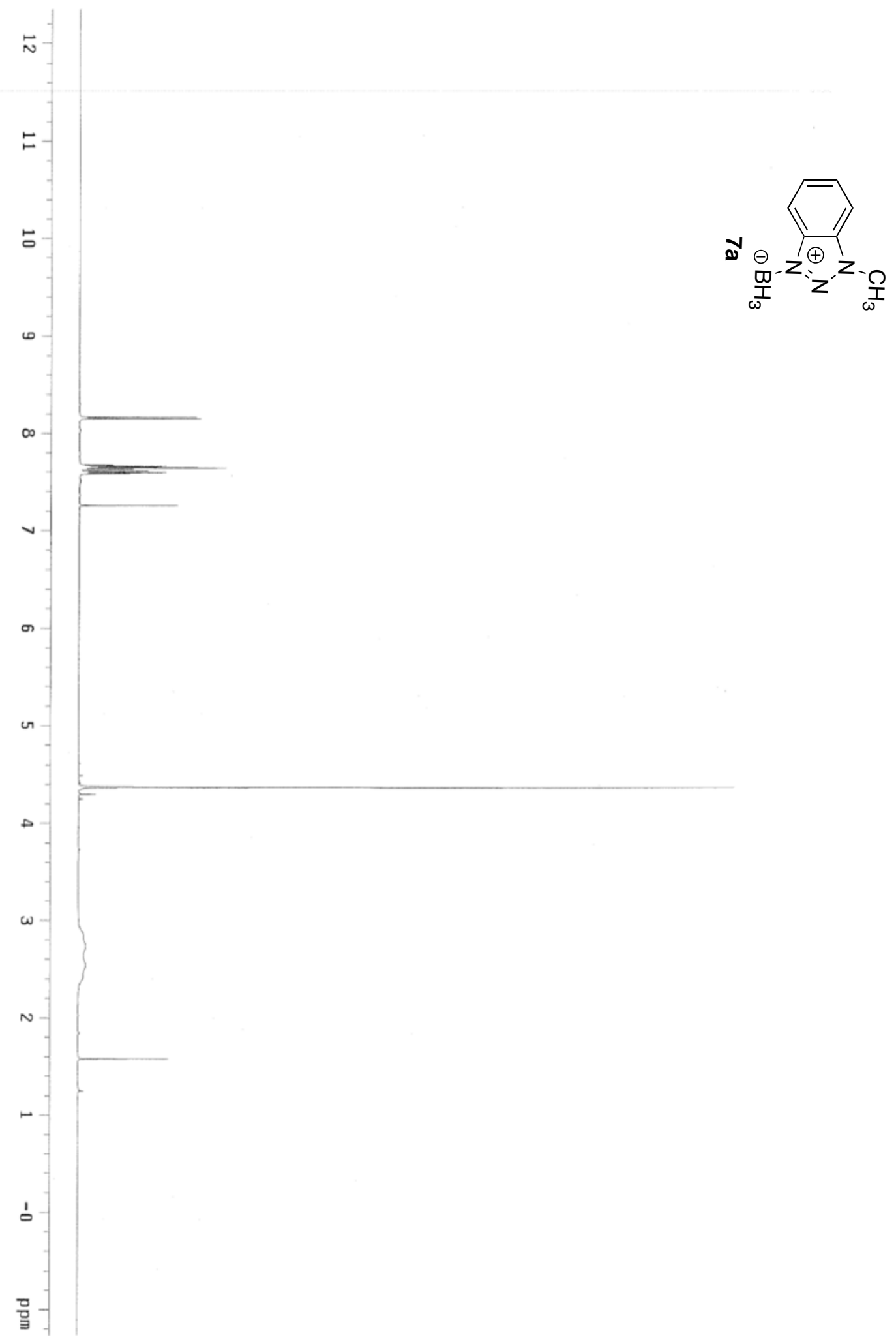




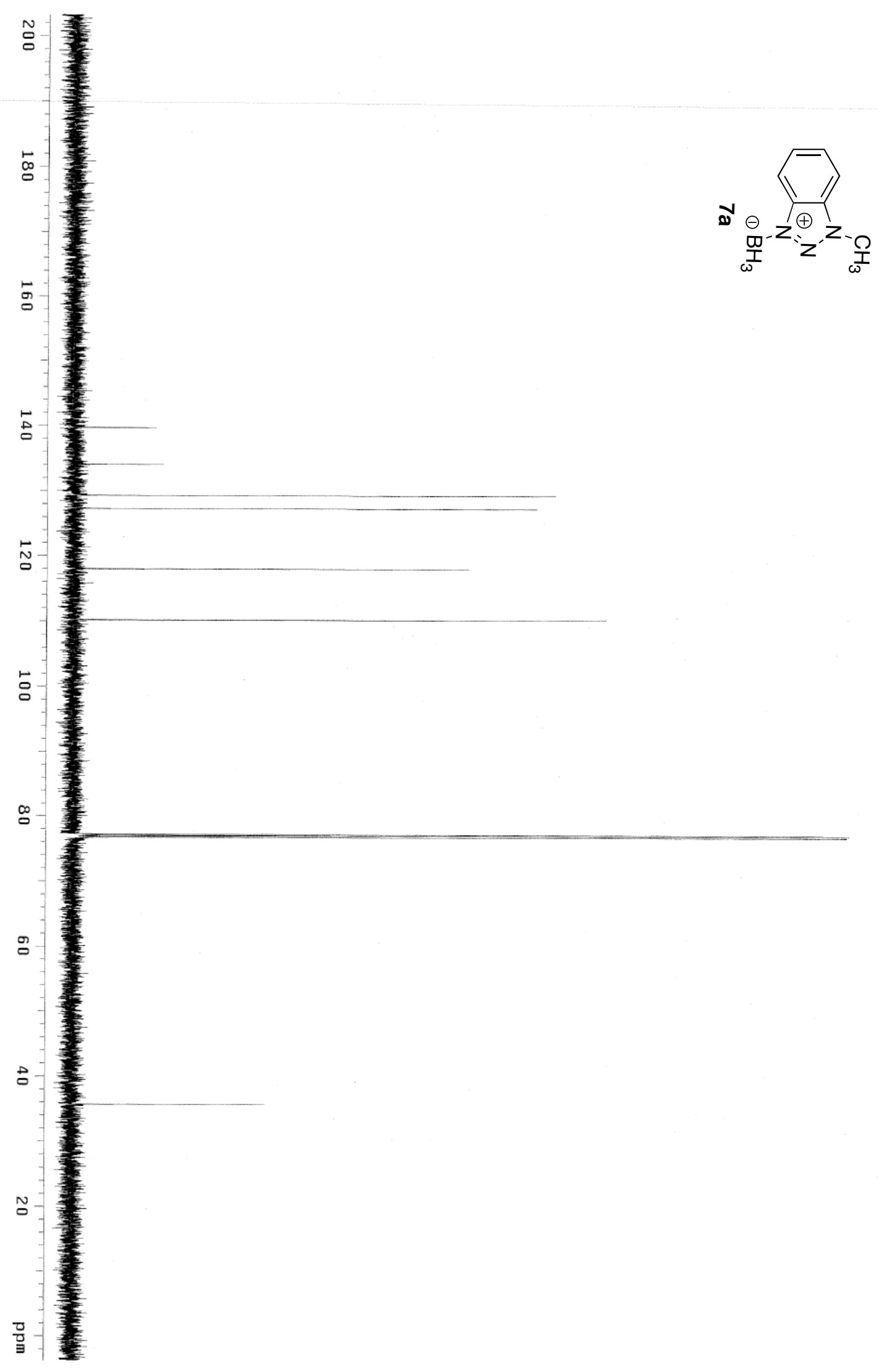




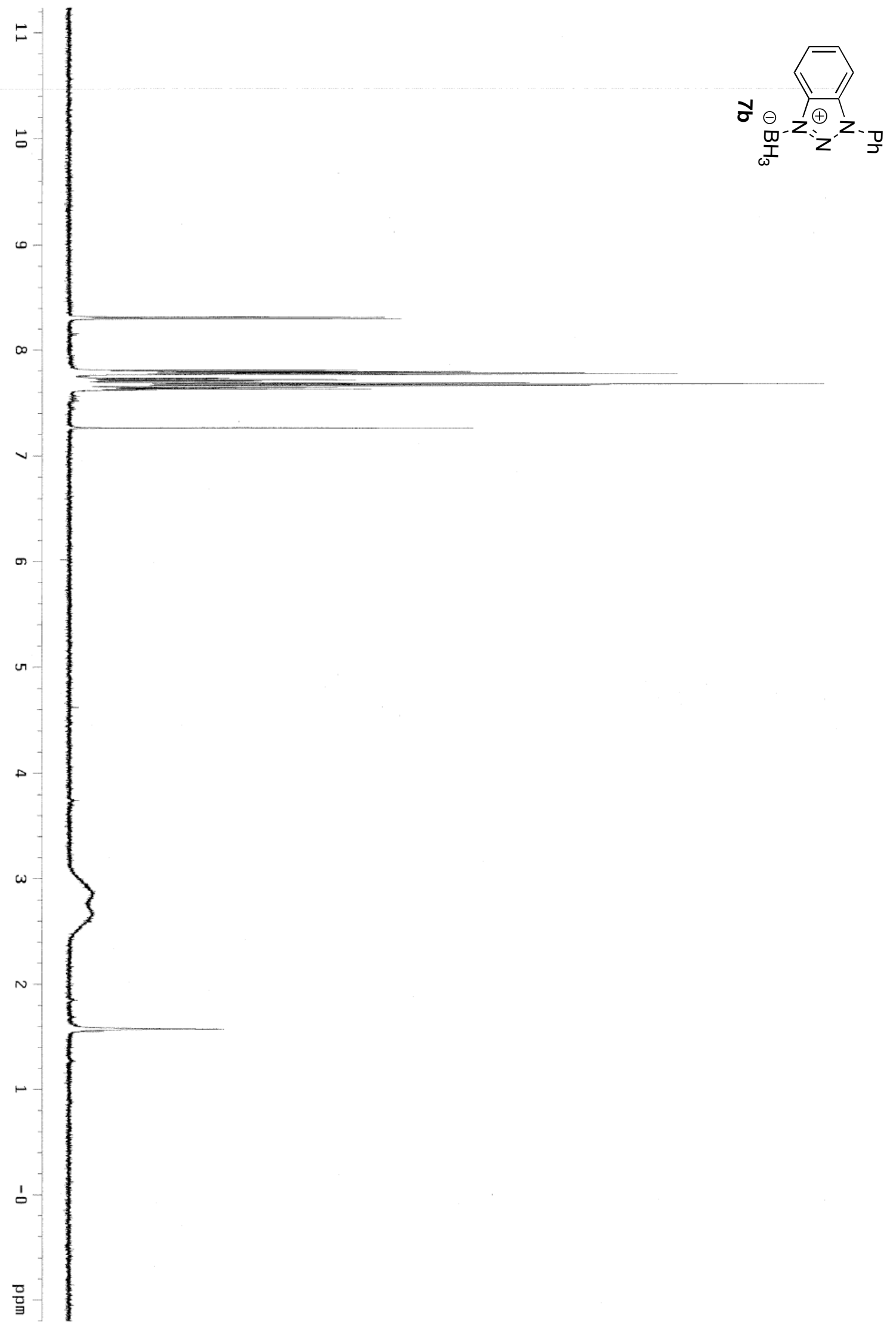




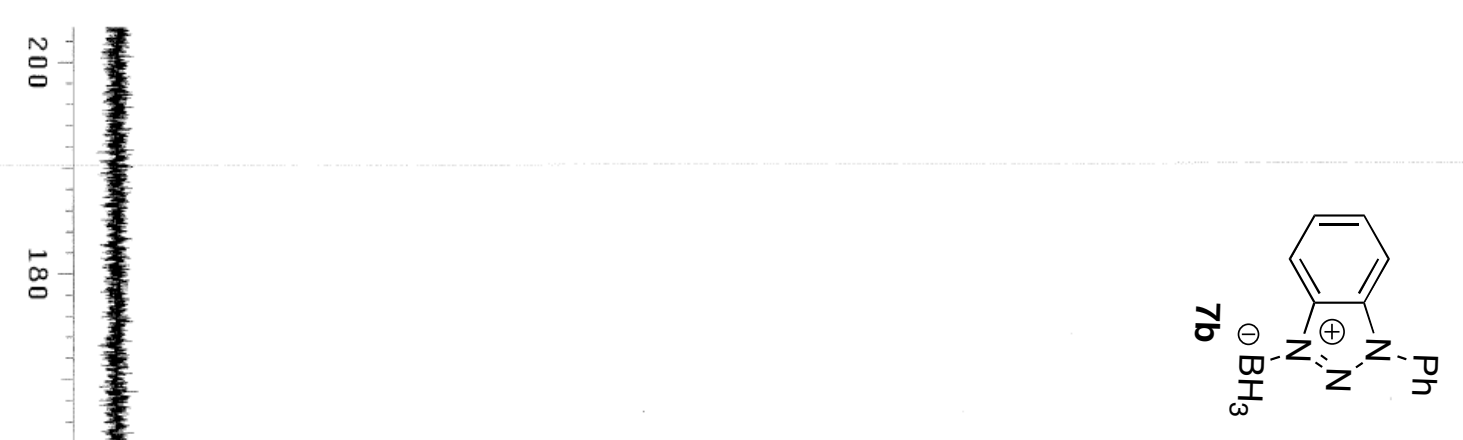

$\stackrel{\square}{\circ}$

ब

N-

娄

g.

a

N

믕 


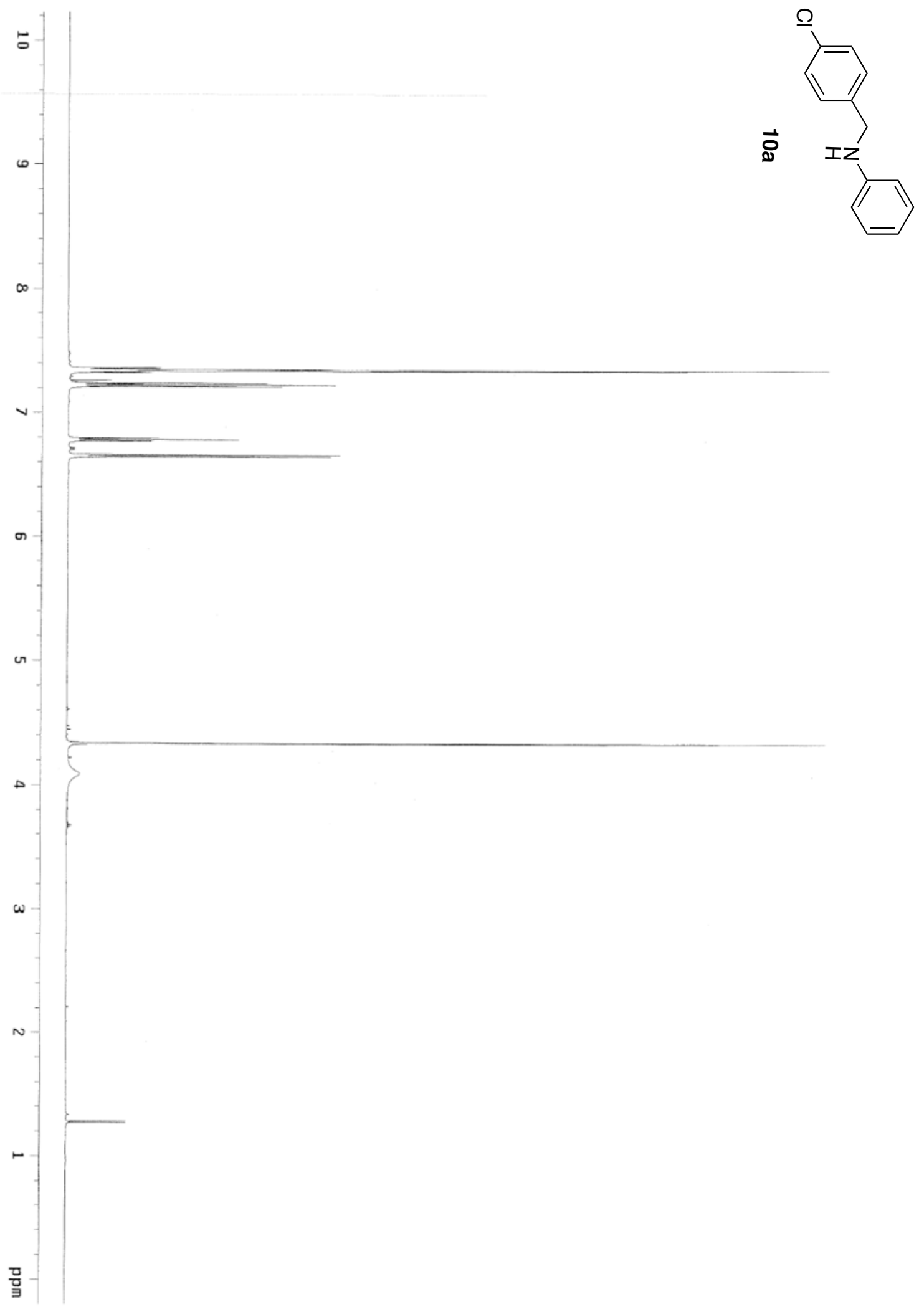




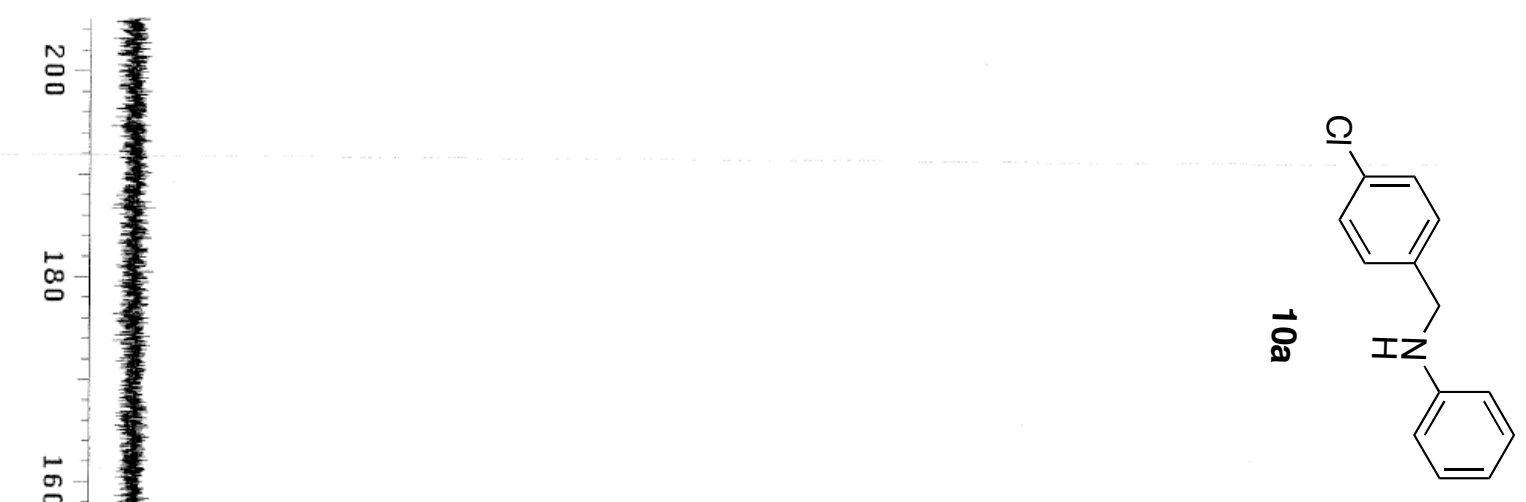

$\stackrel{\infty}{\circ}$

음

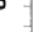

政

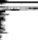

政

g

b-

ㄱ-

$\circ$

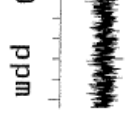




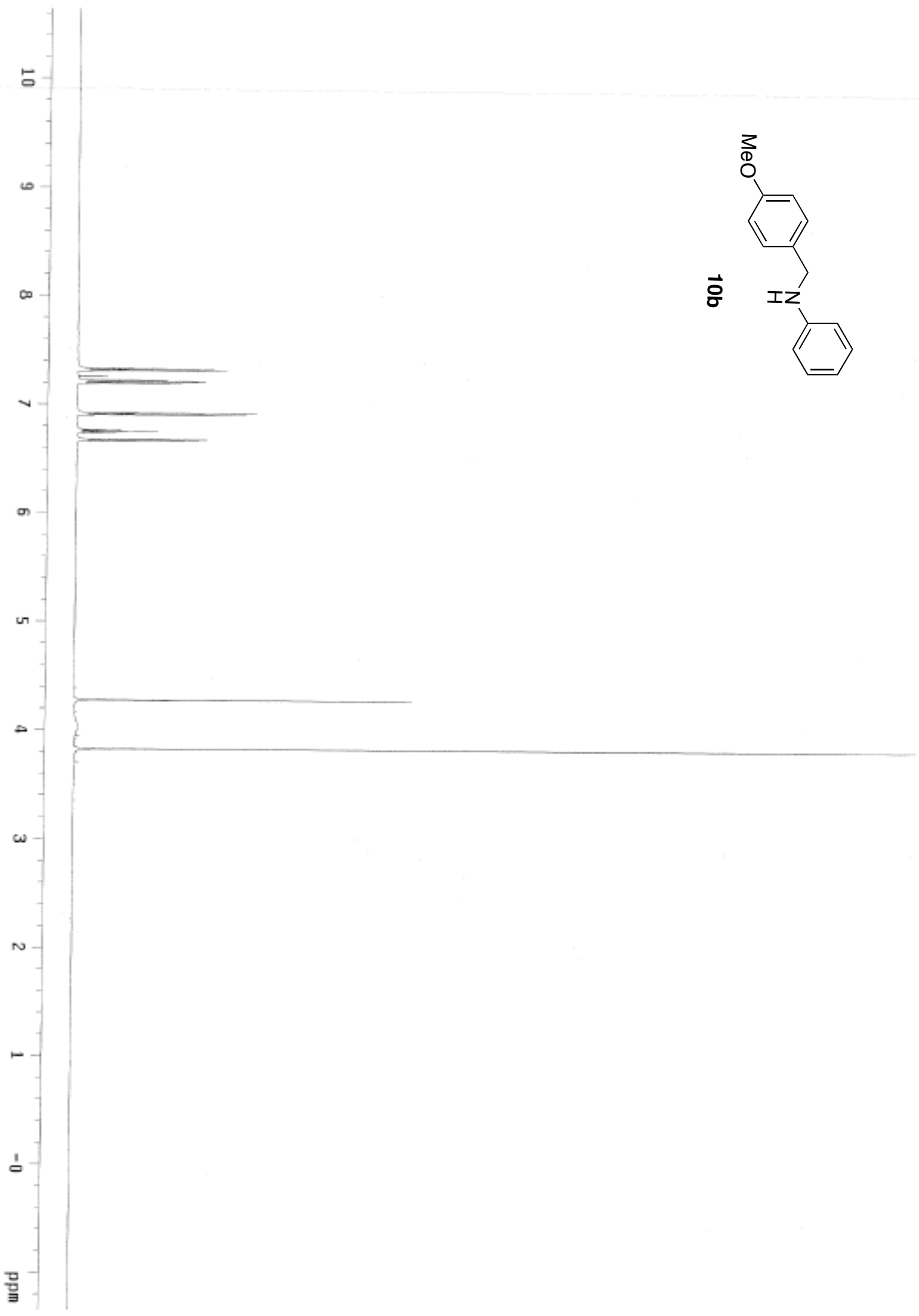




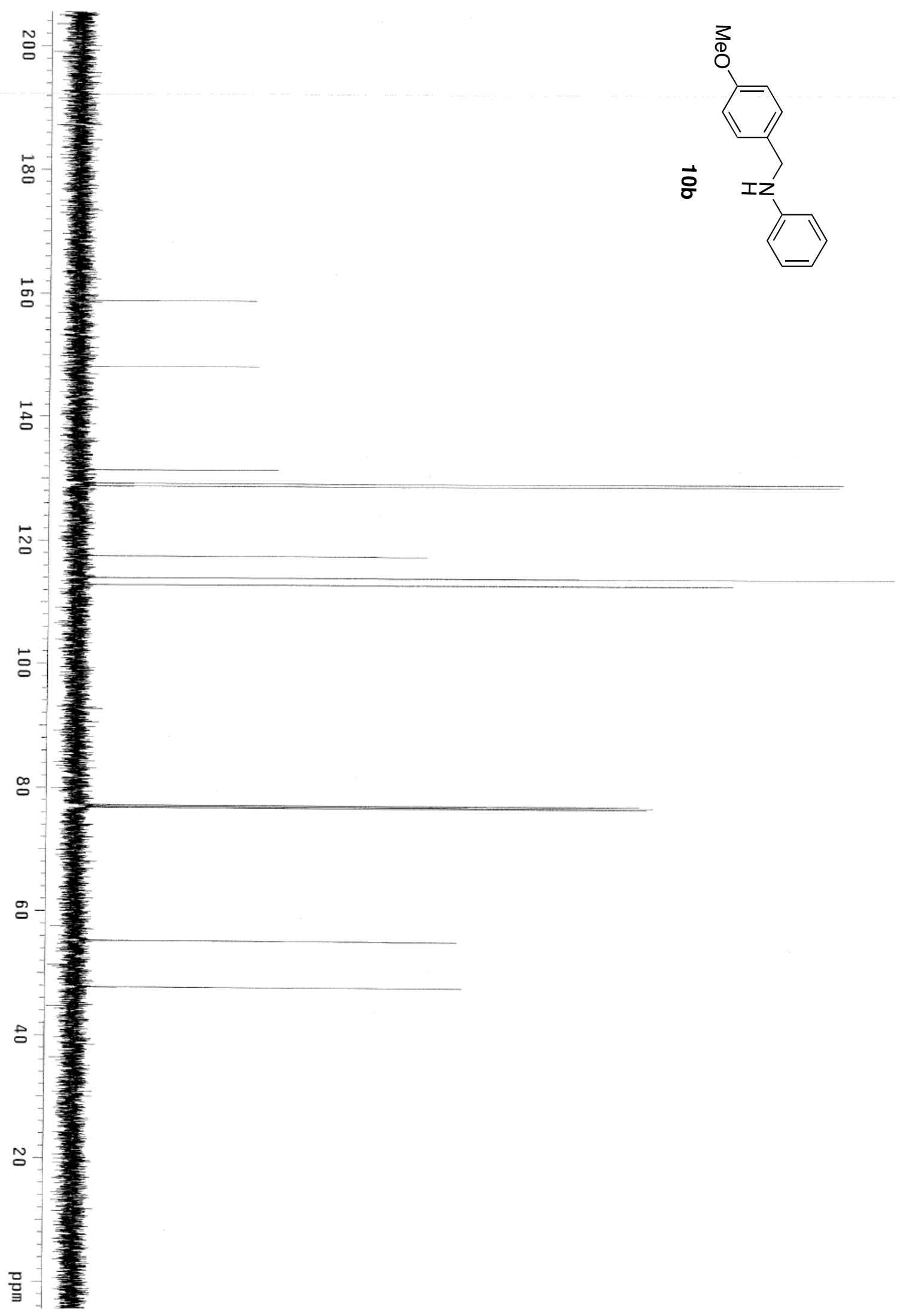




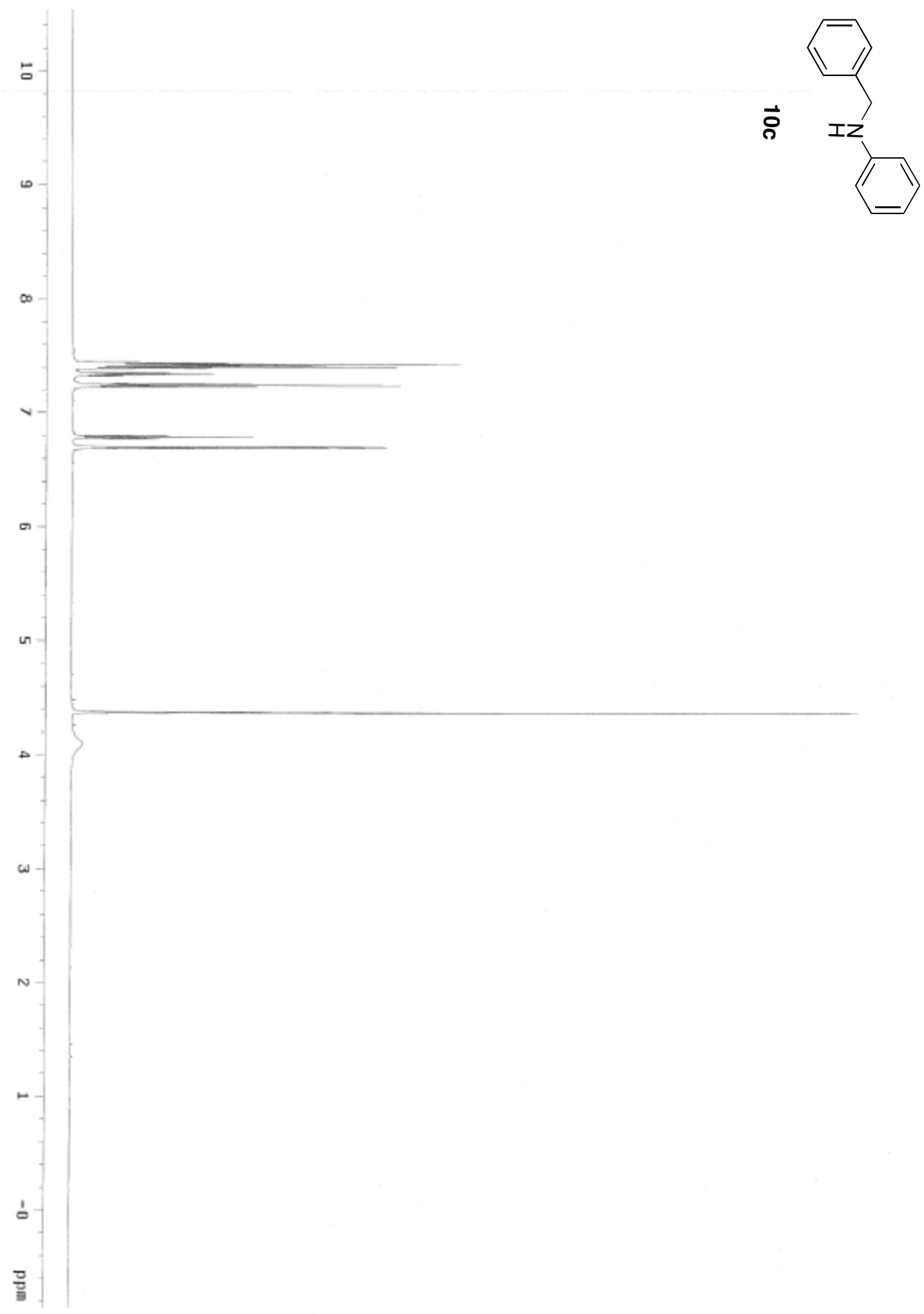




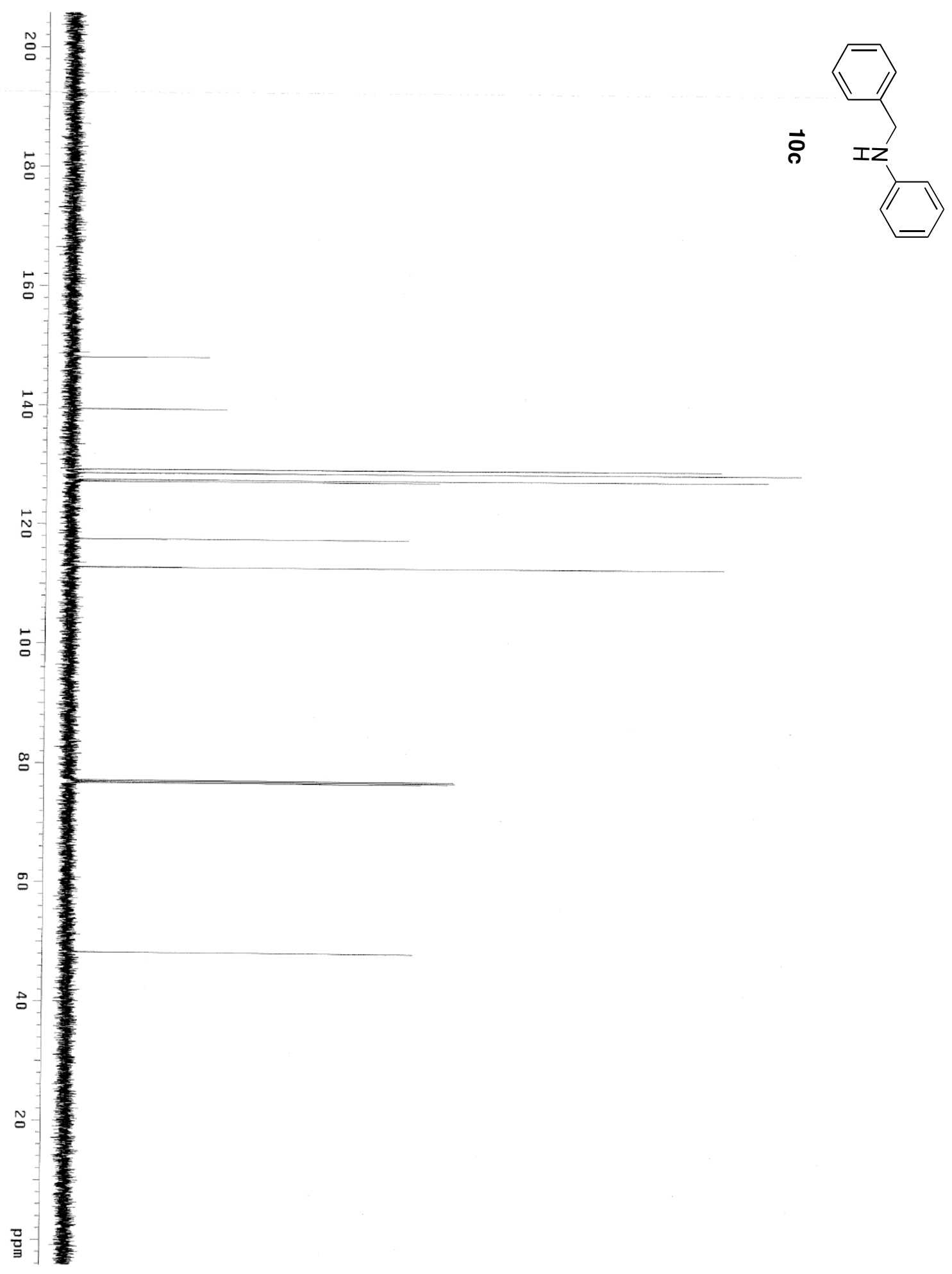




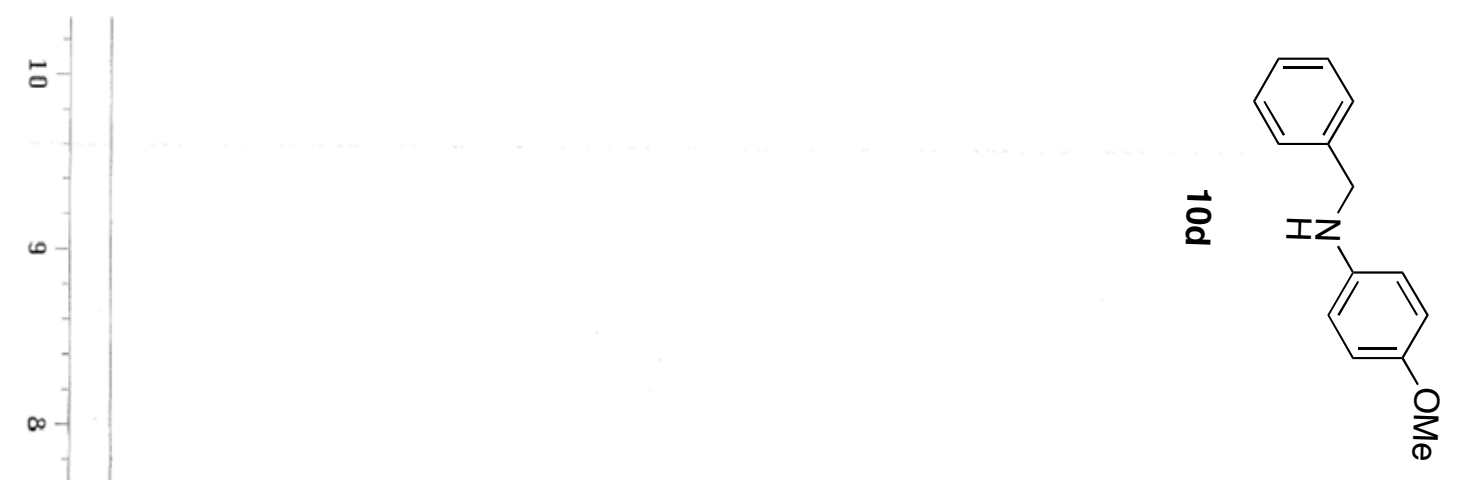

v

$\rightarrow$

$\omega$

$v$

o

$N$

1

!

뭅 


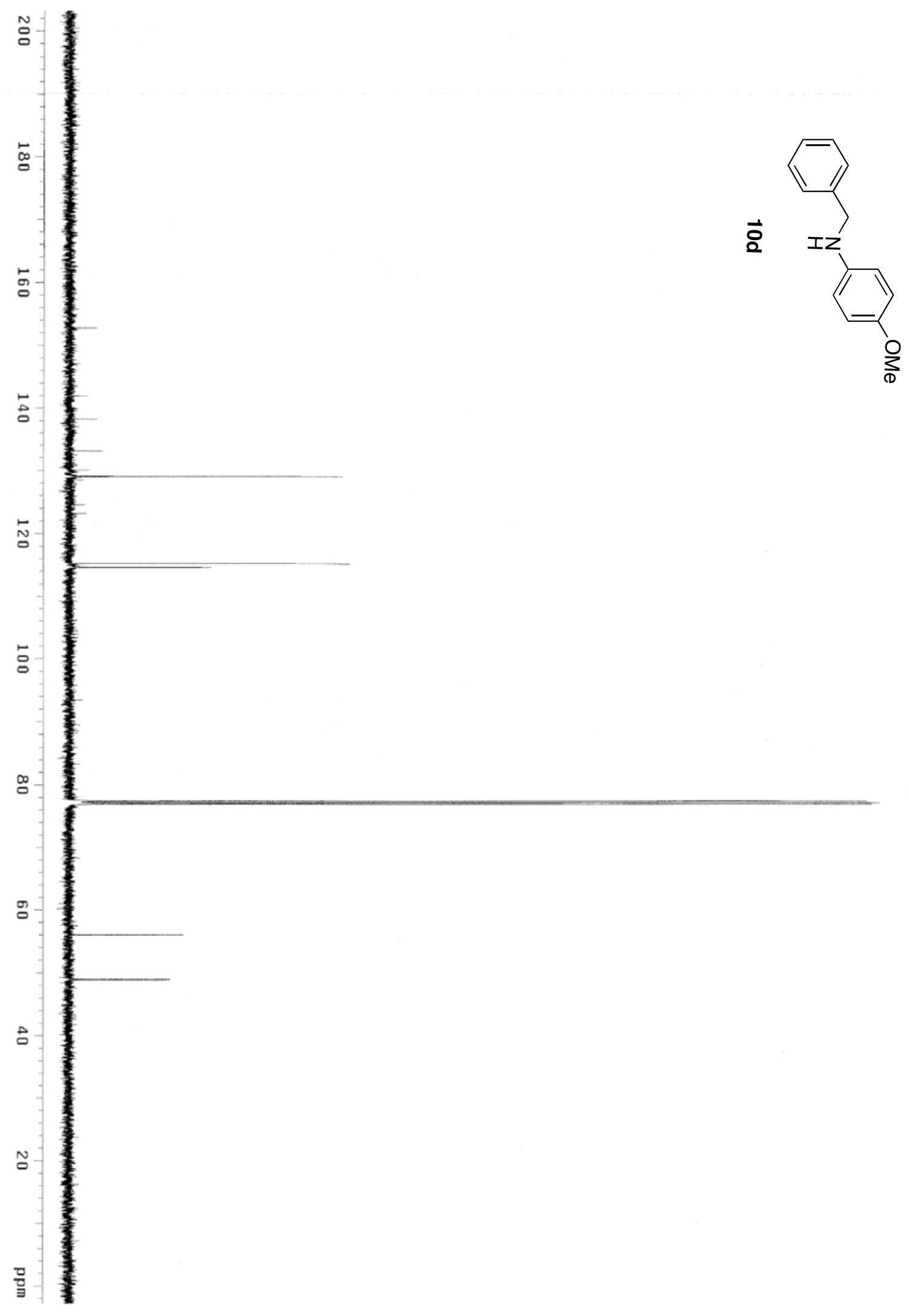




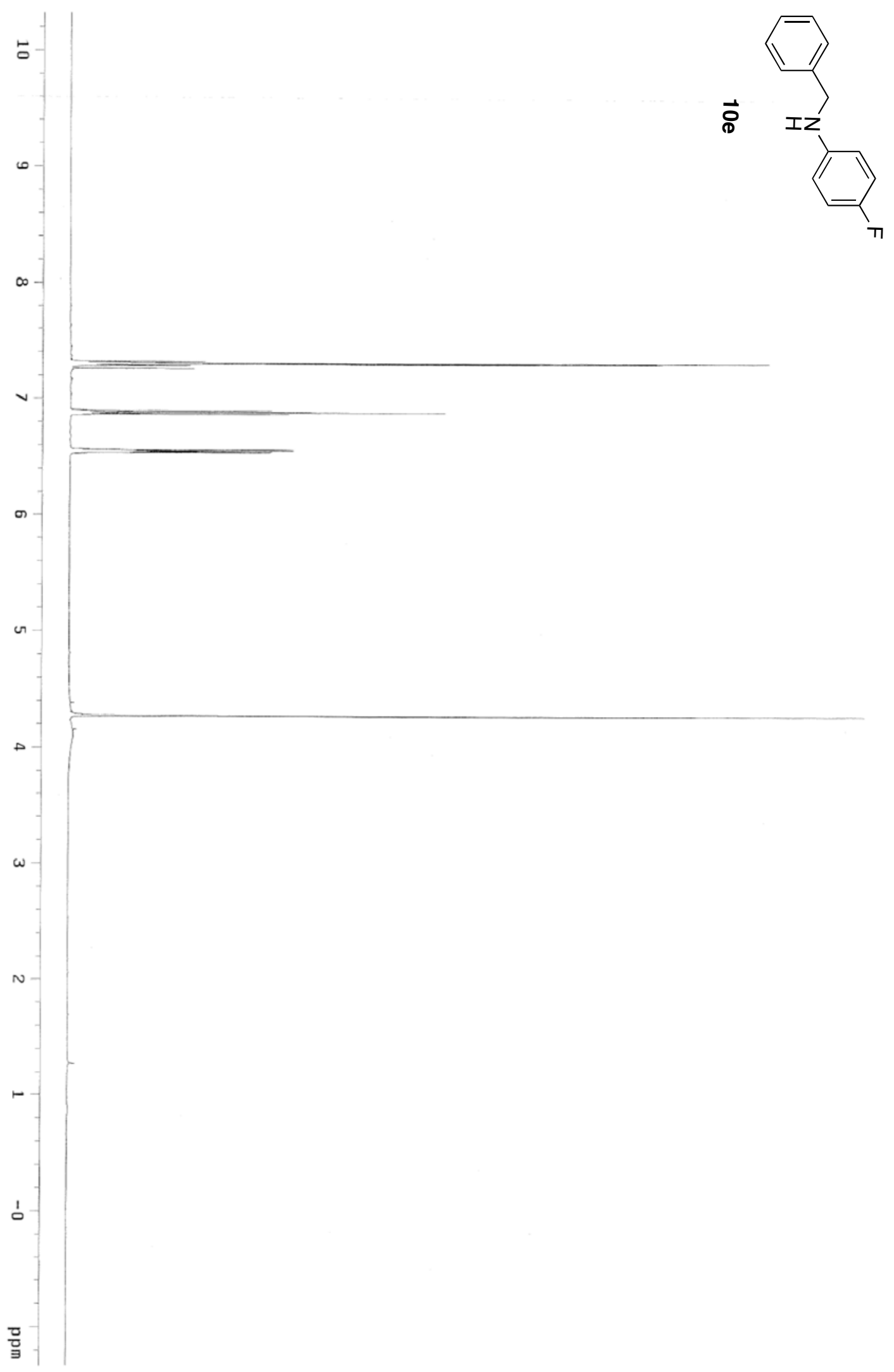




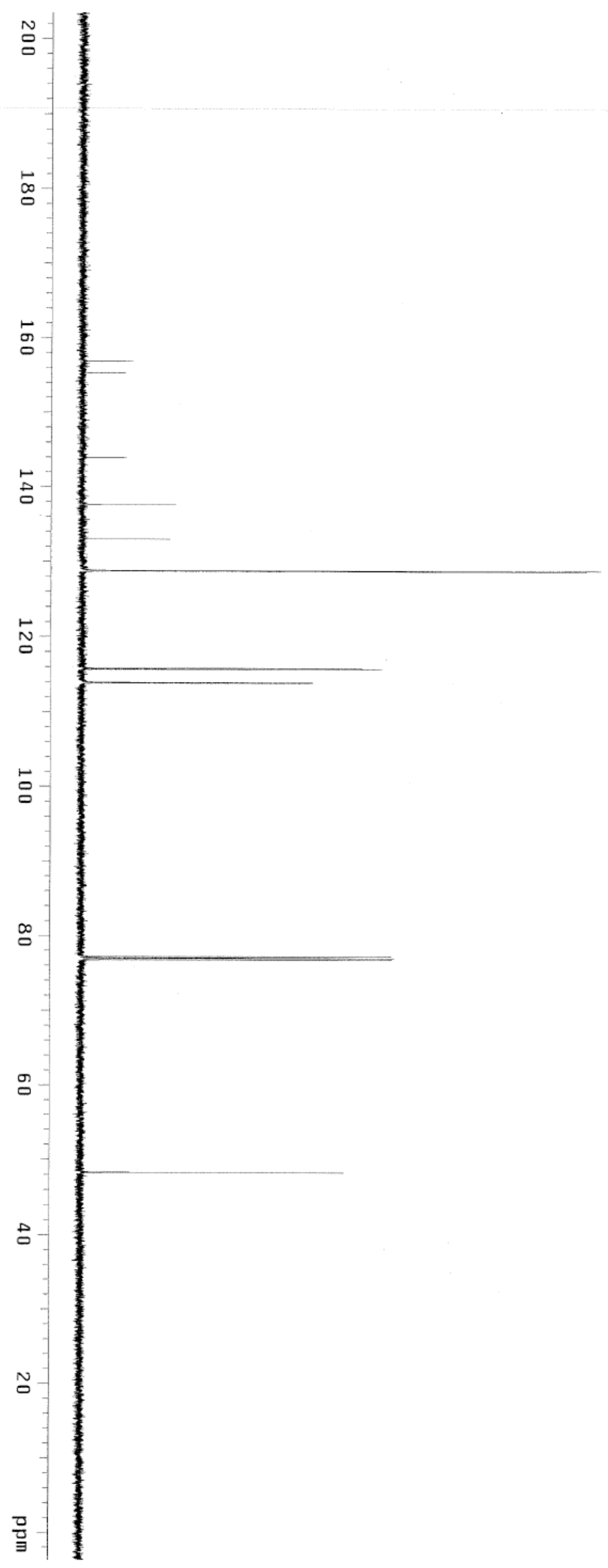




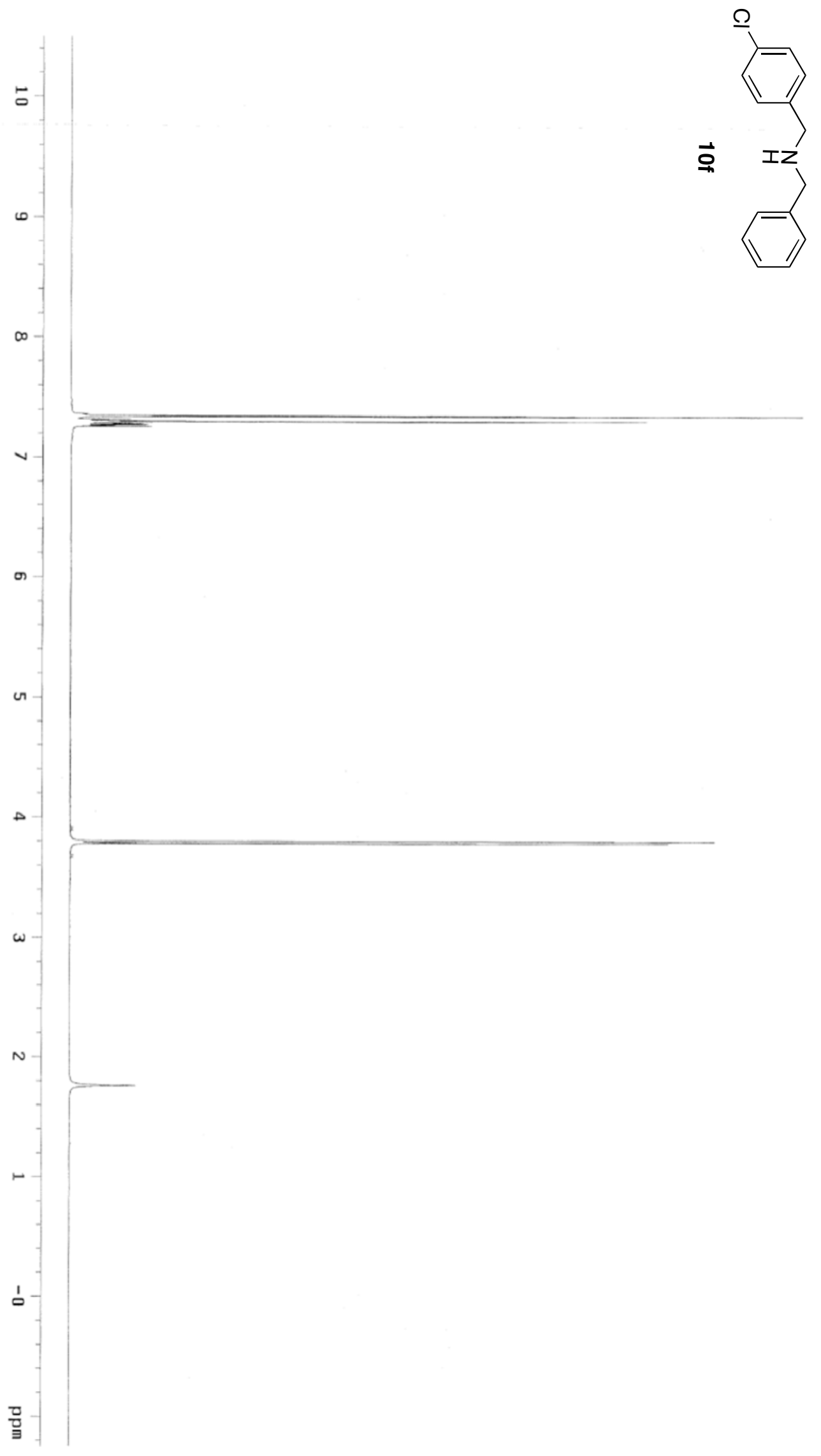




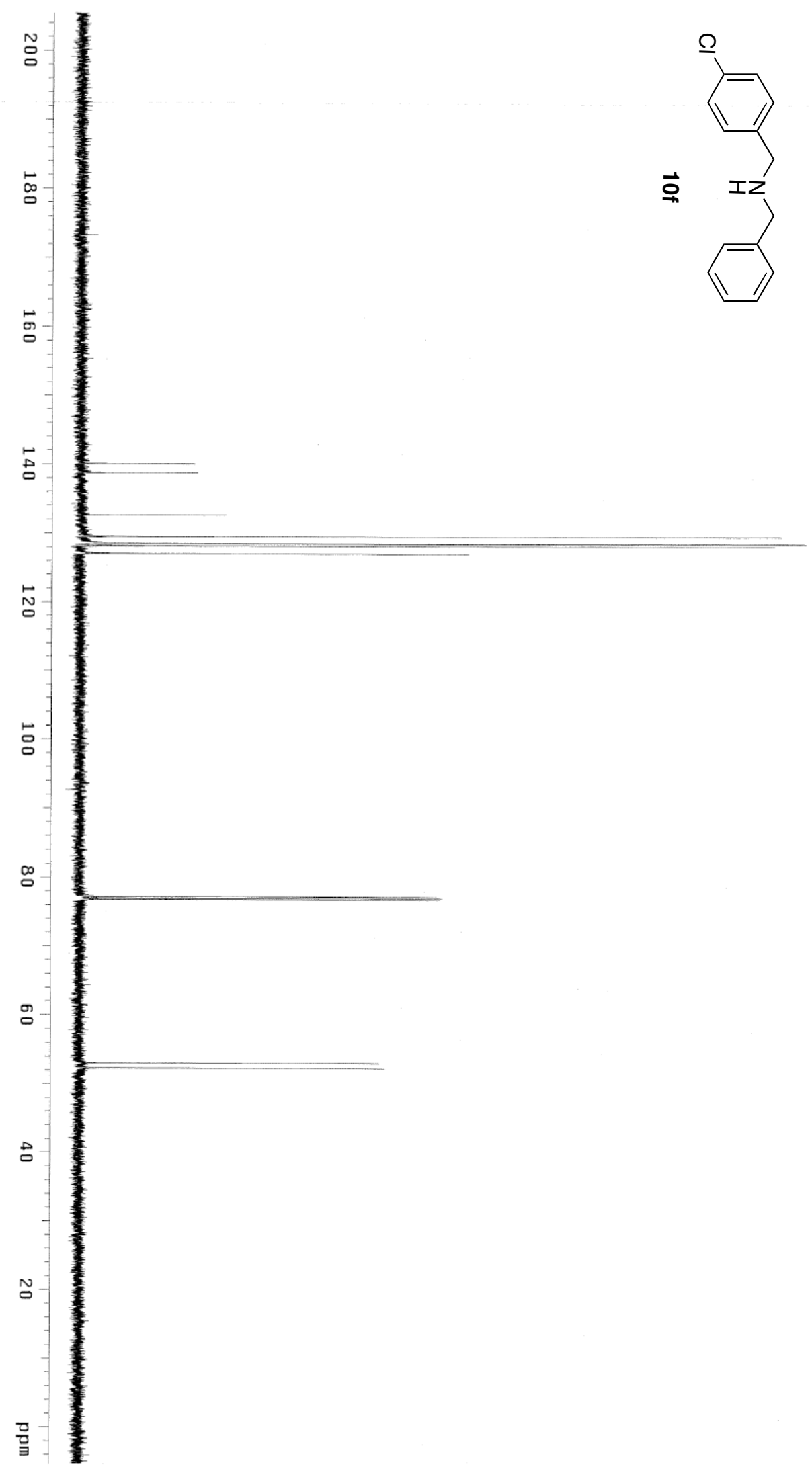




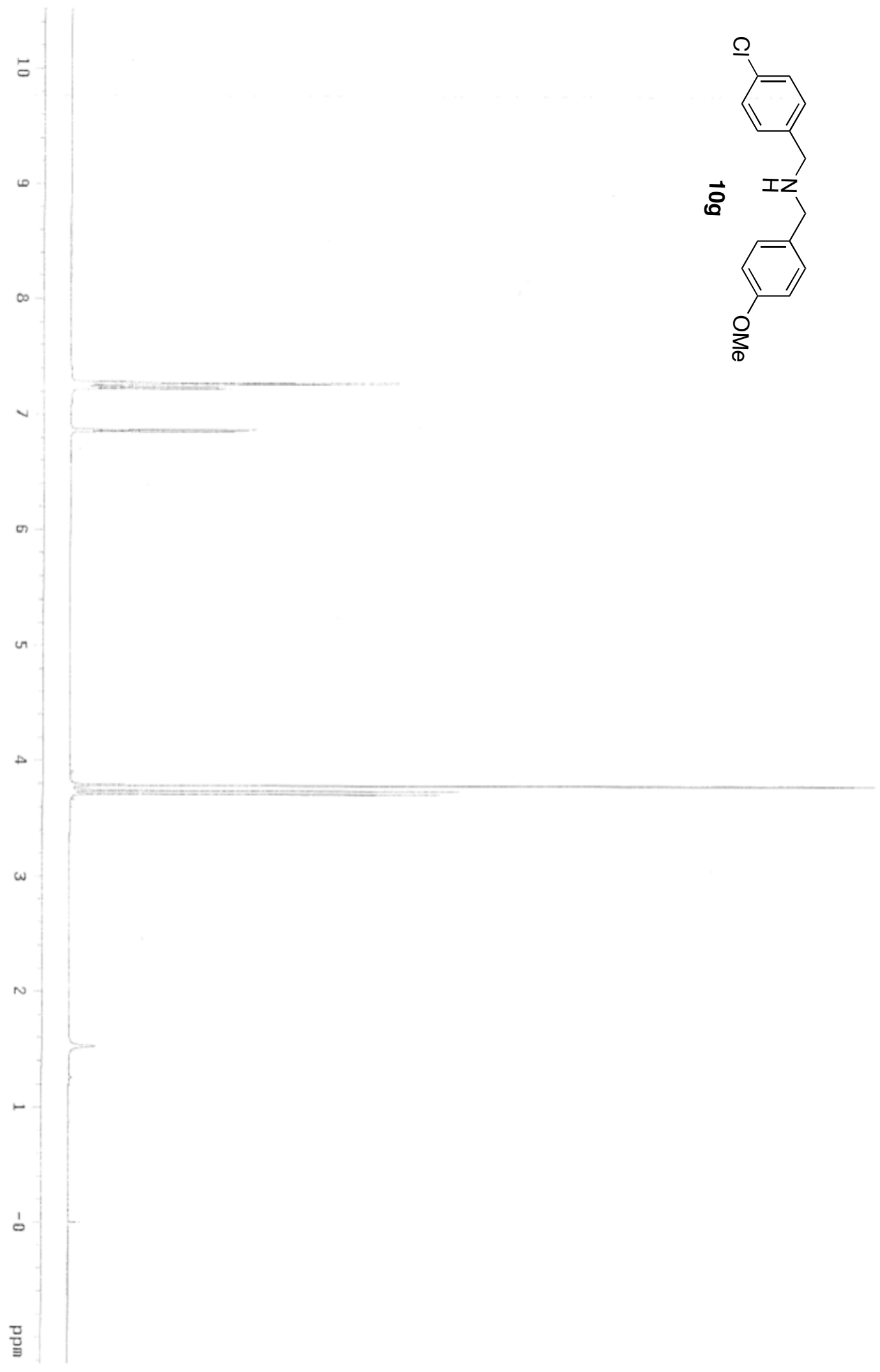




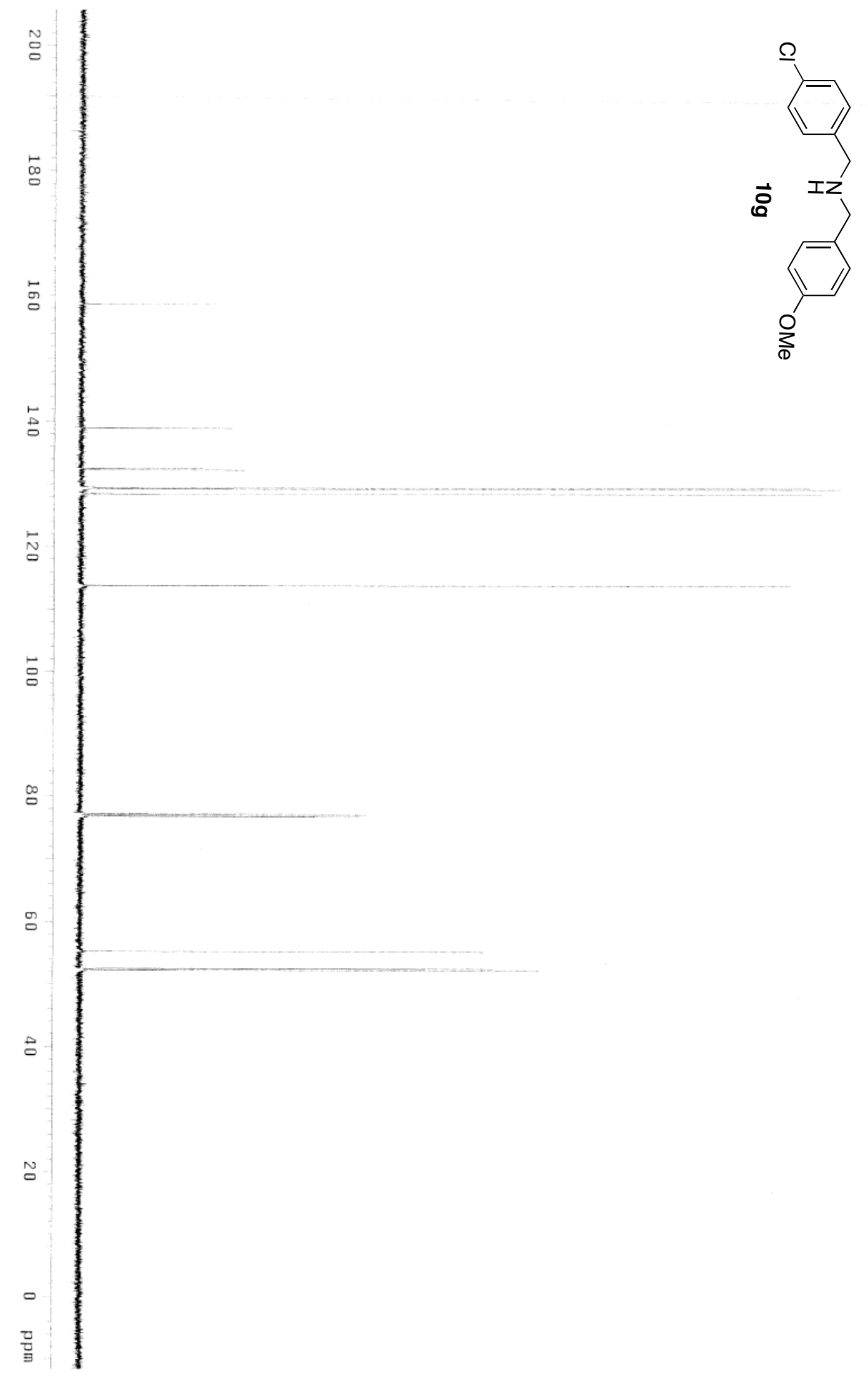




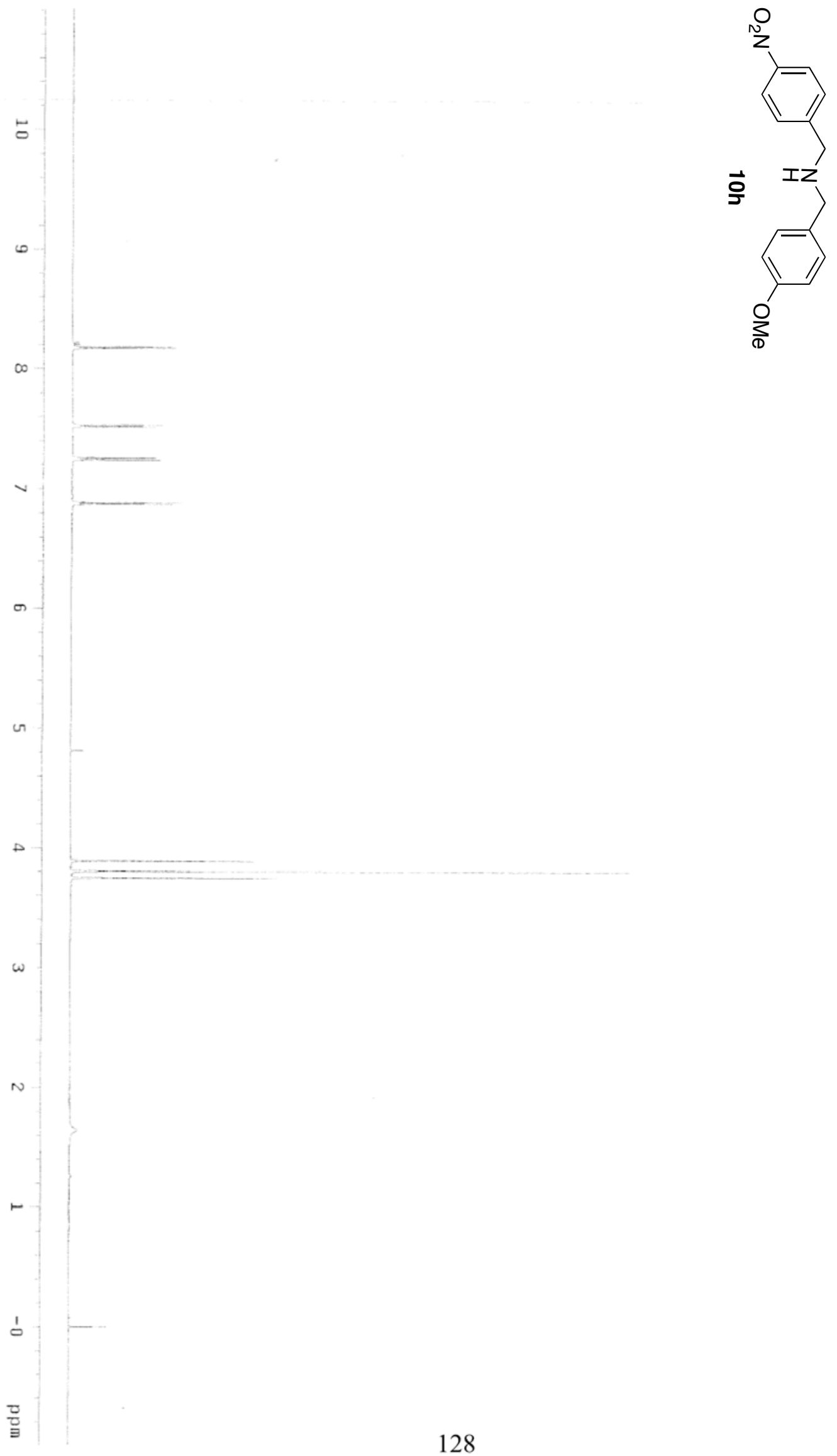



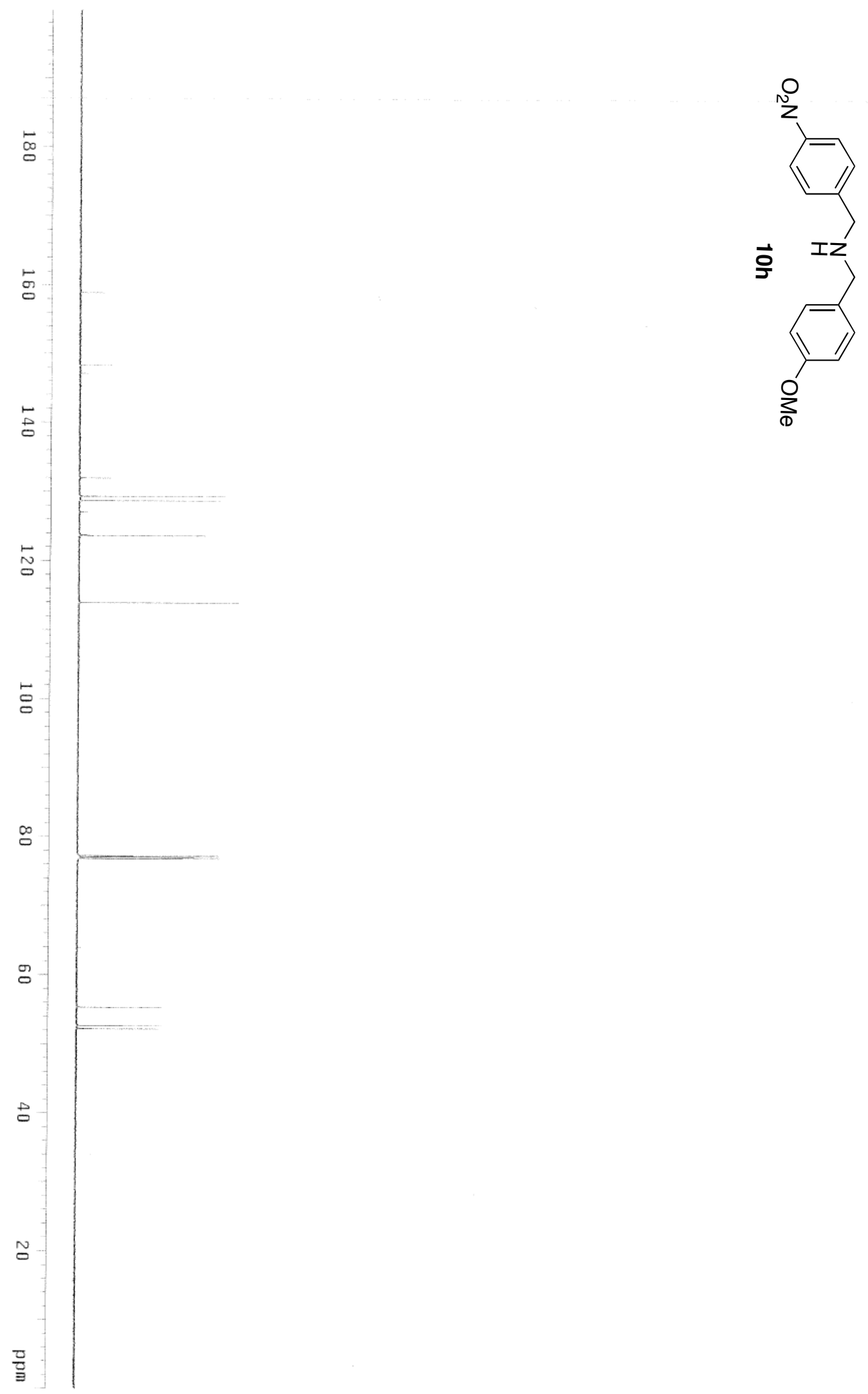


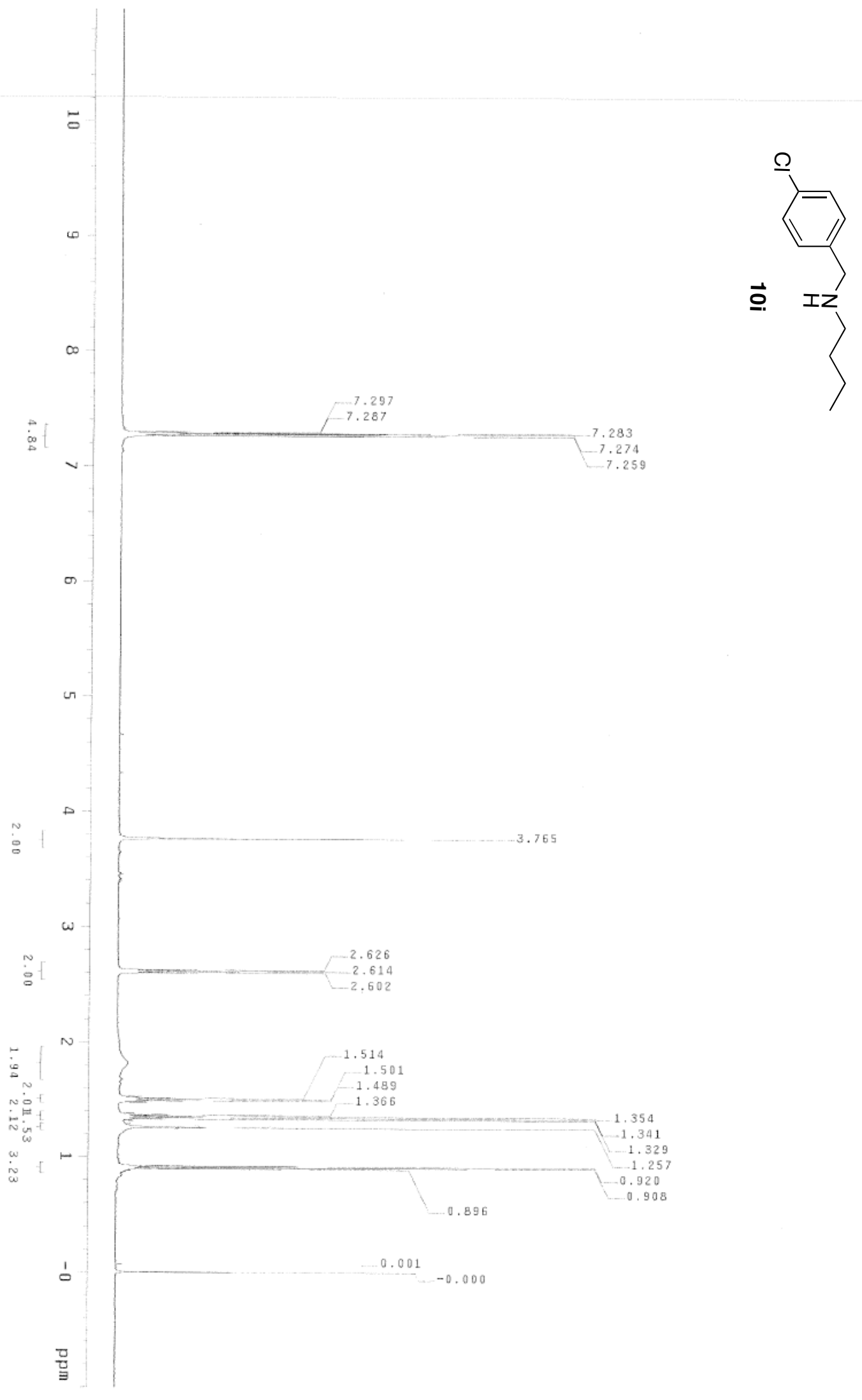




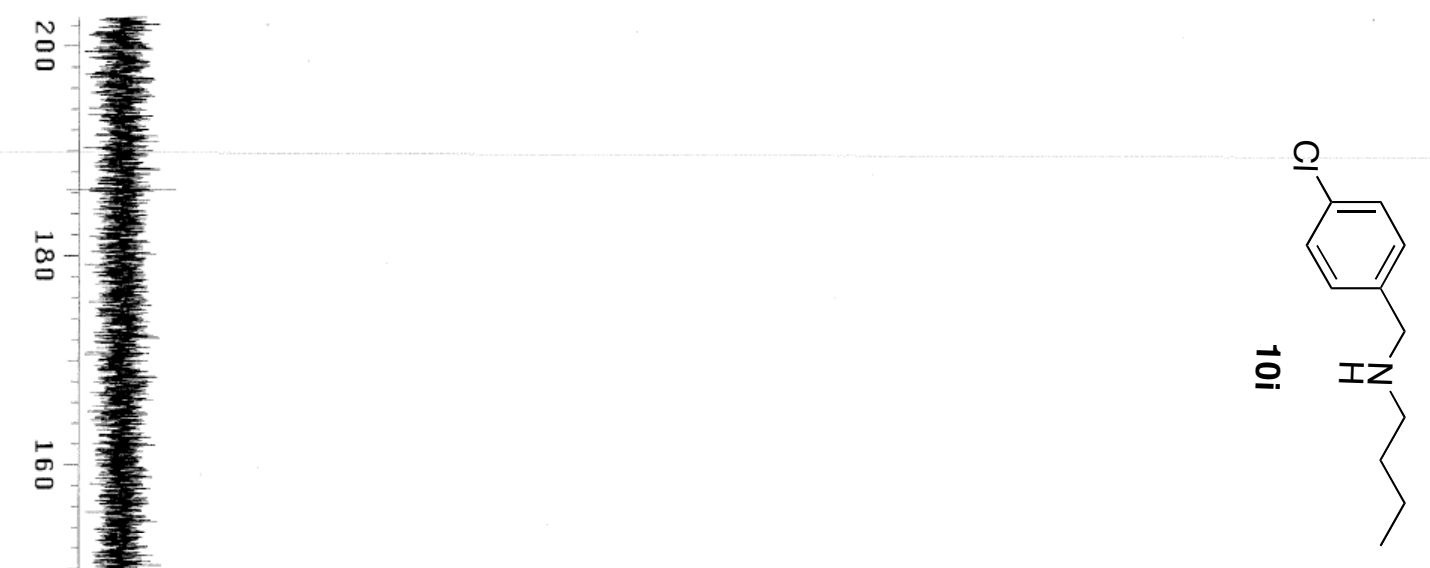

$\stackrel{N}{\square}$

$\infty$

$\circ$

$\stackrel{5}{\circ}$

:

-

正

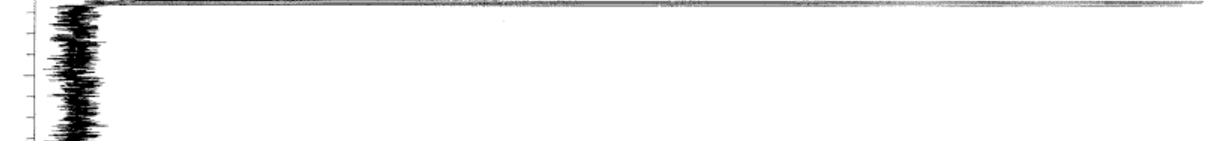

b



新

N.

$-1$

- 


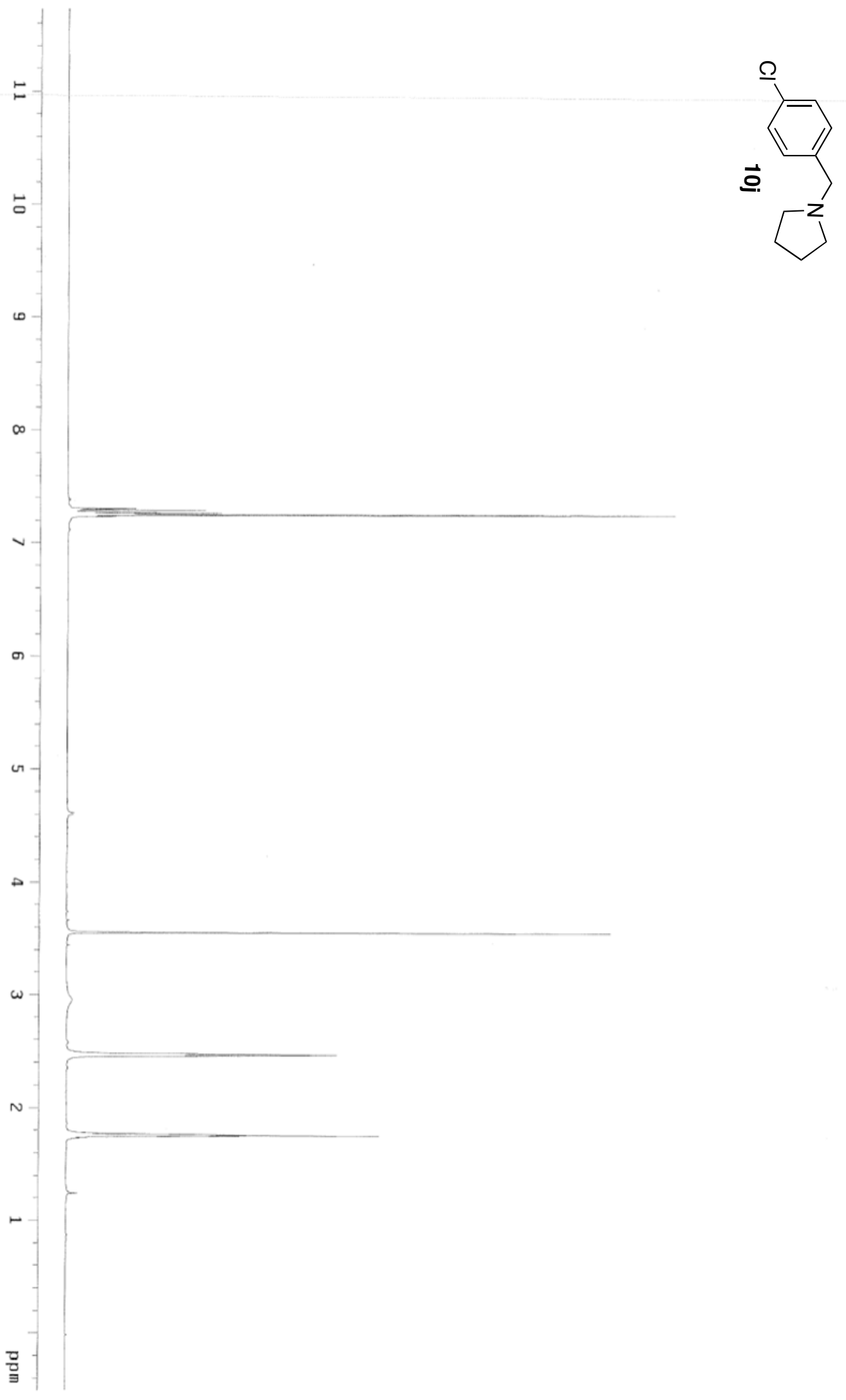



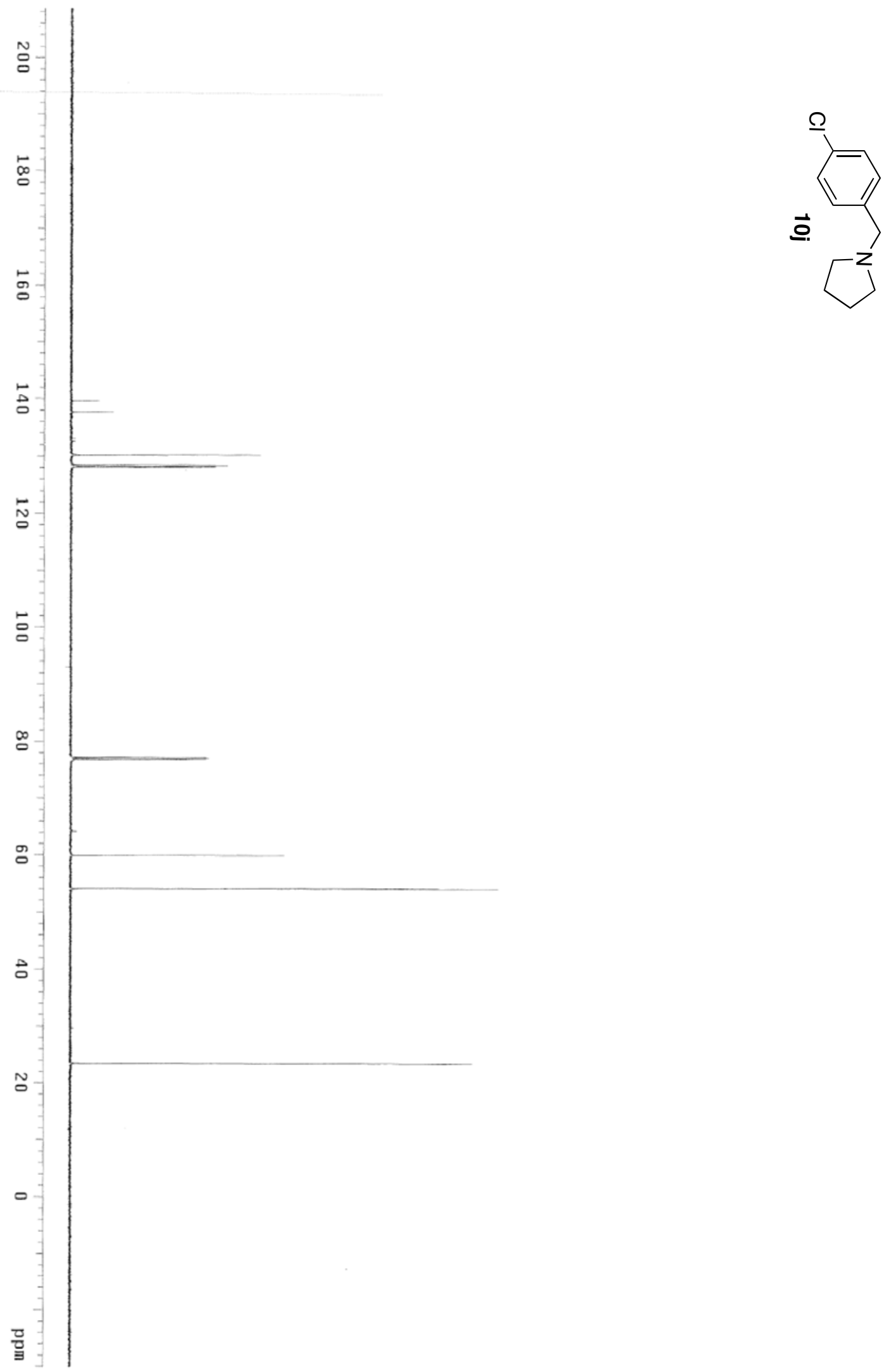


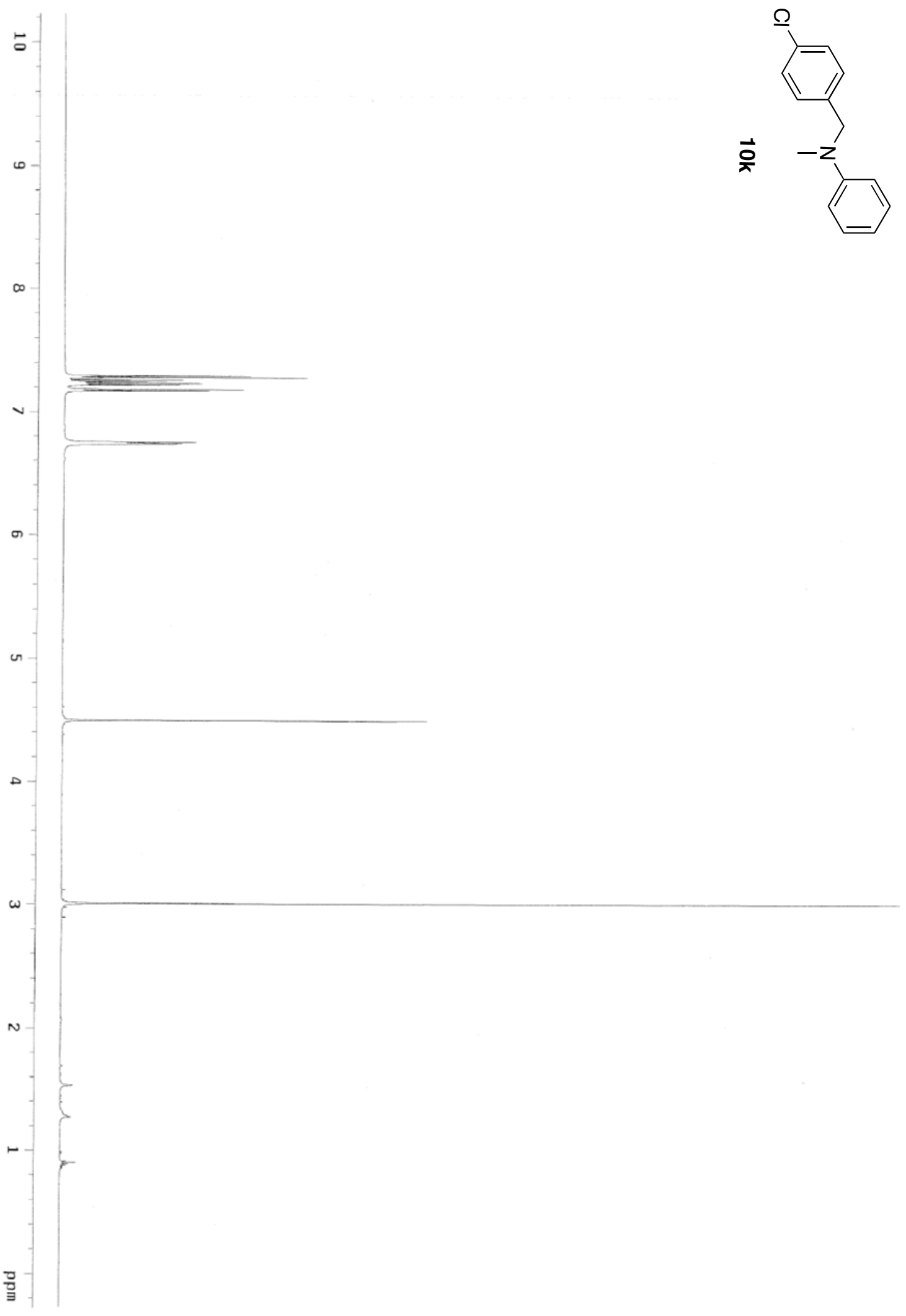




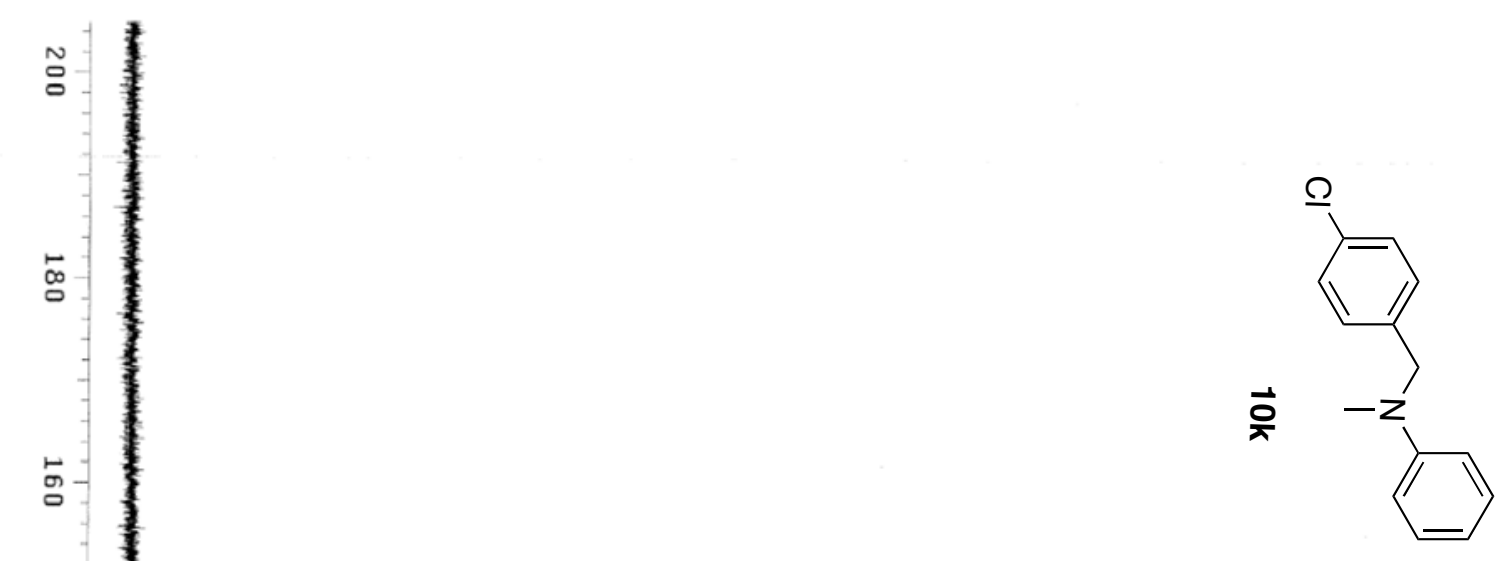

$\stackrel{\infty}{\circ}$

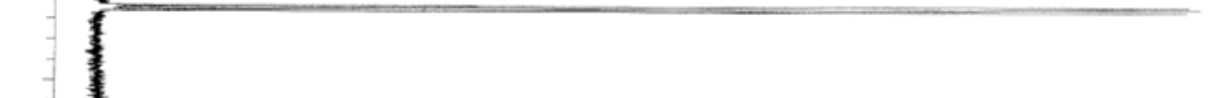

ㅁำ

号

$\circ$

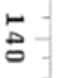

ㄱ.

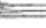

$\stackrel{\circ}{\circ}$

.

ㄱ.

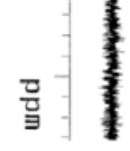




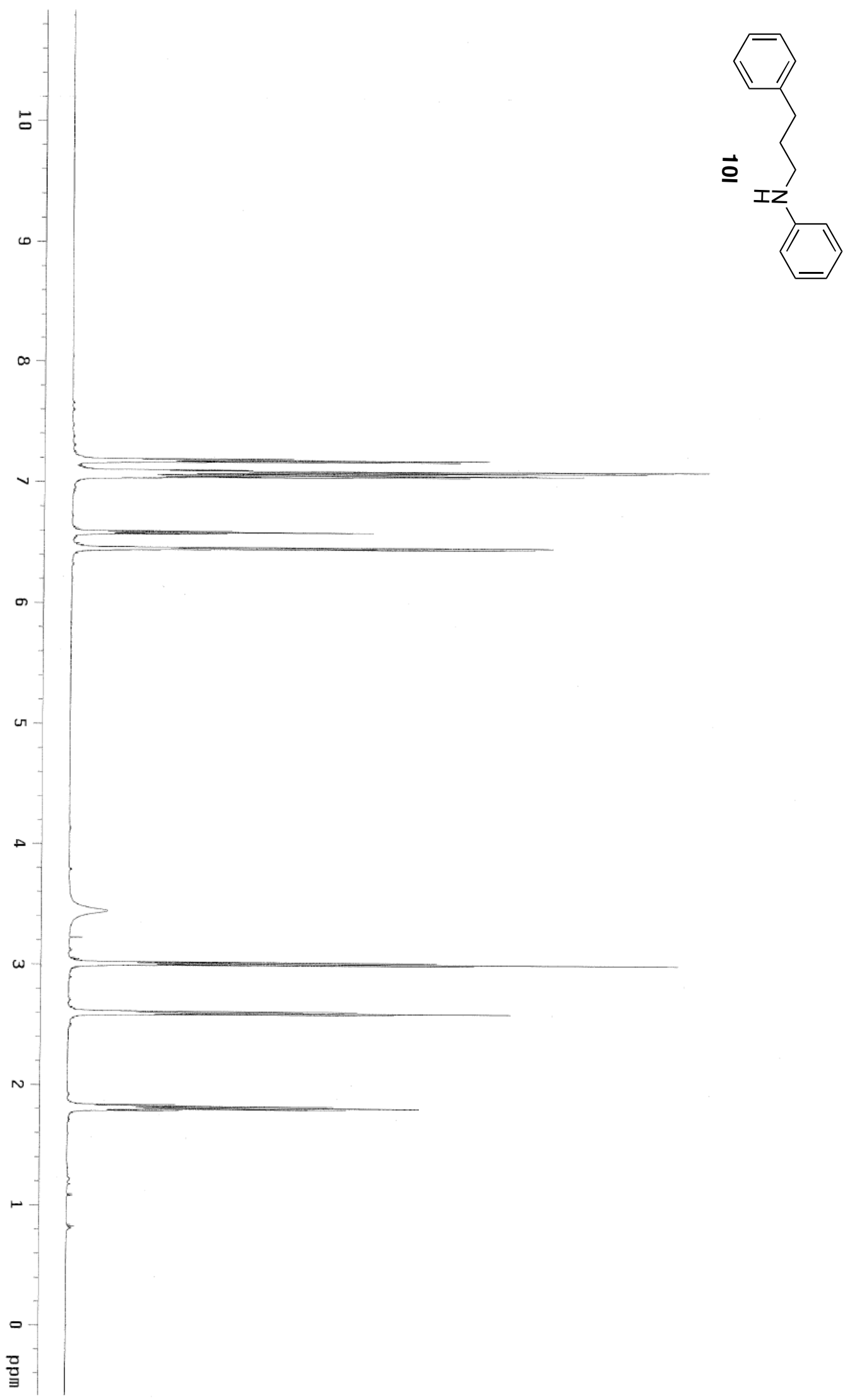



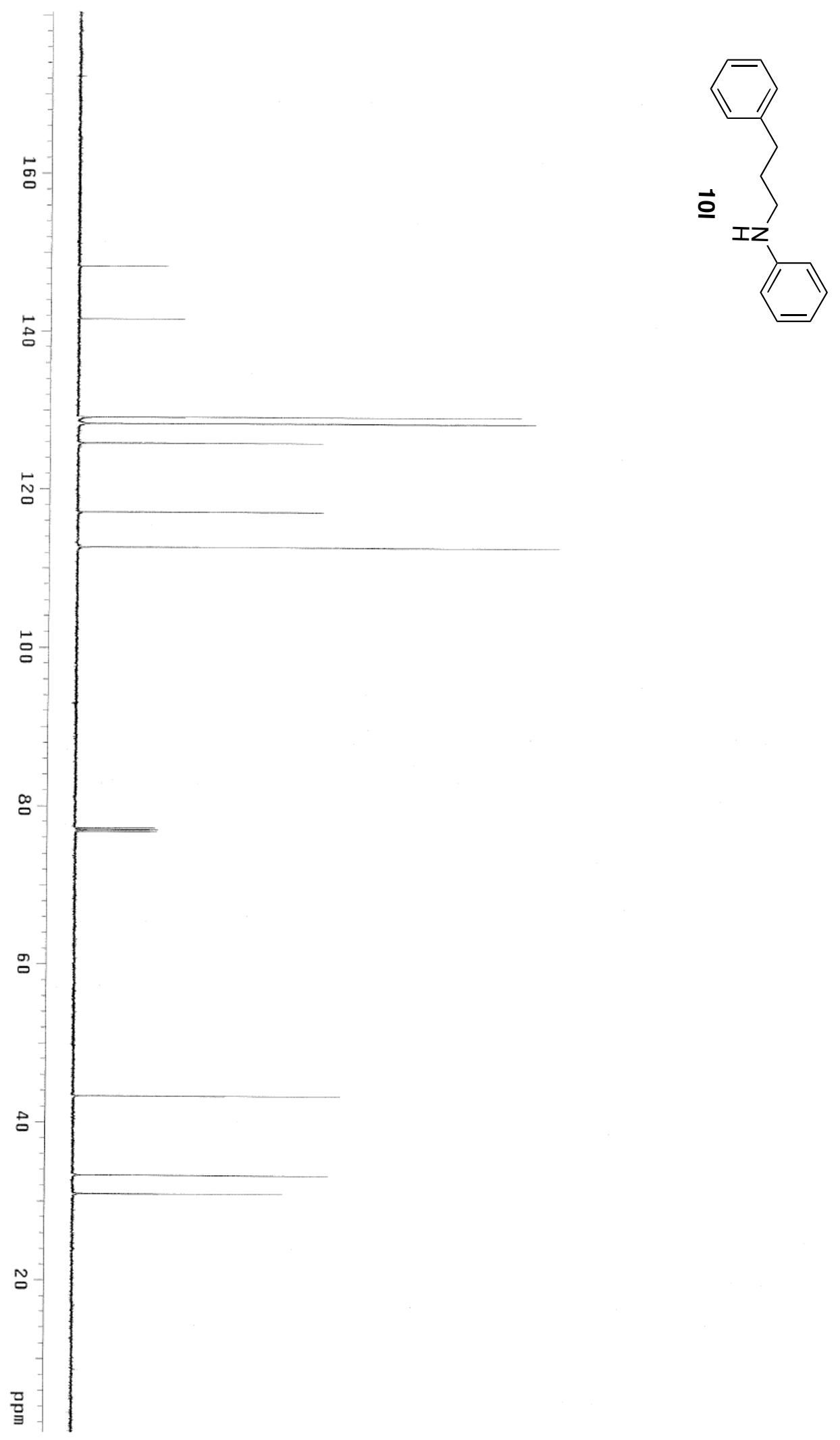


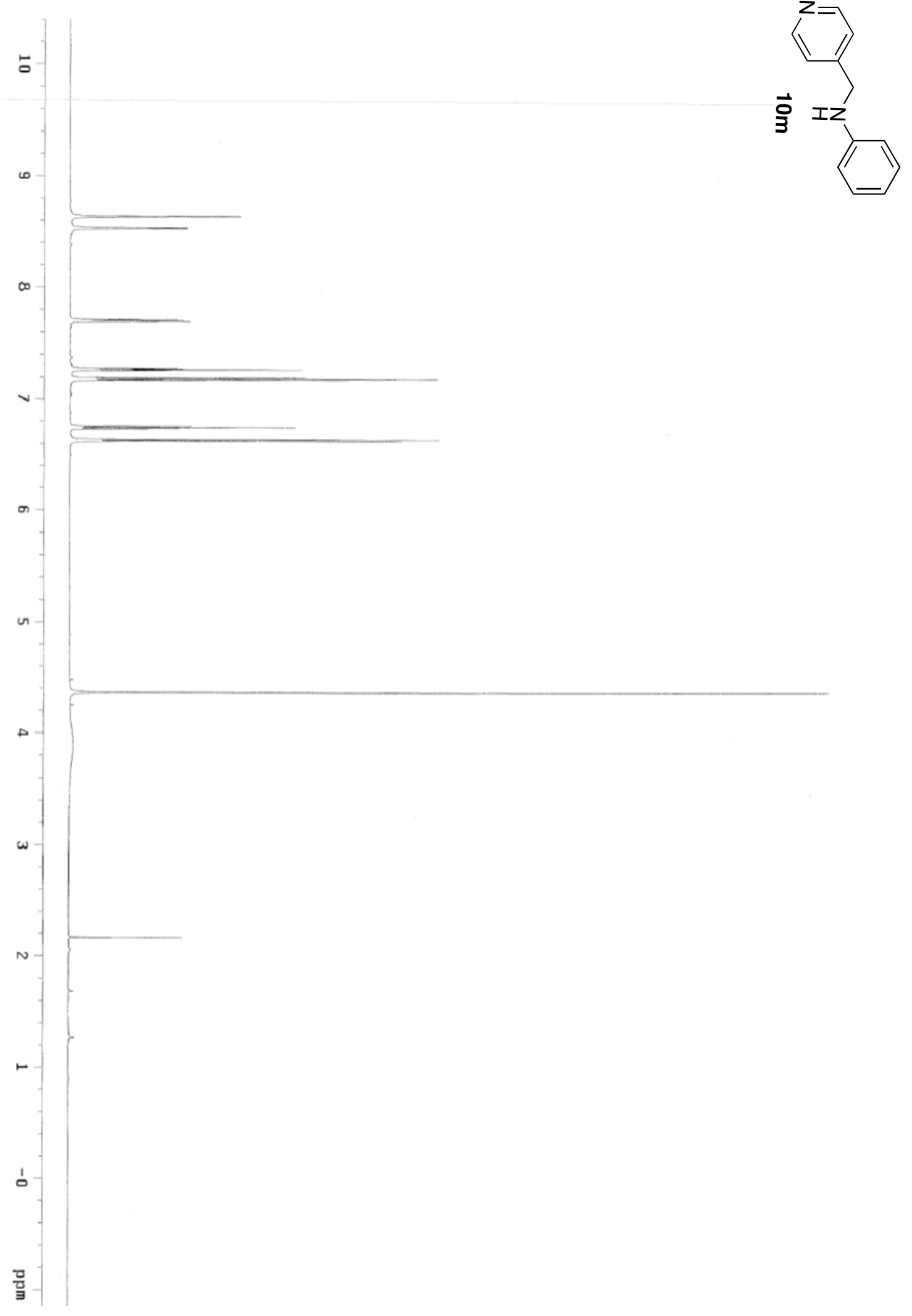



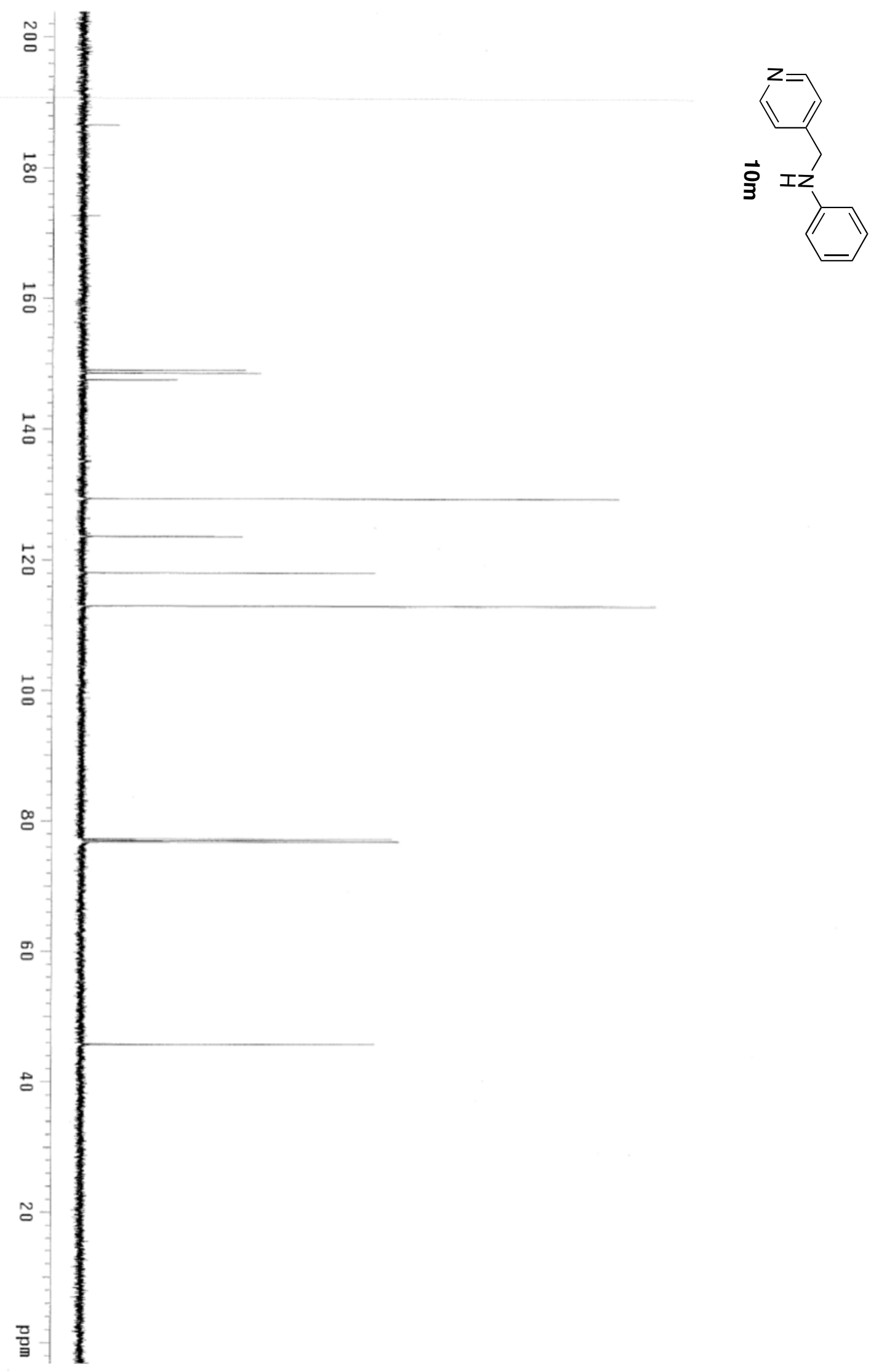


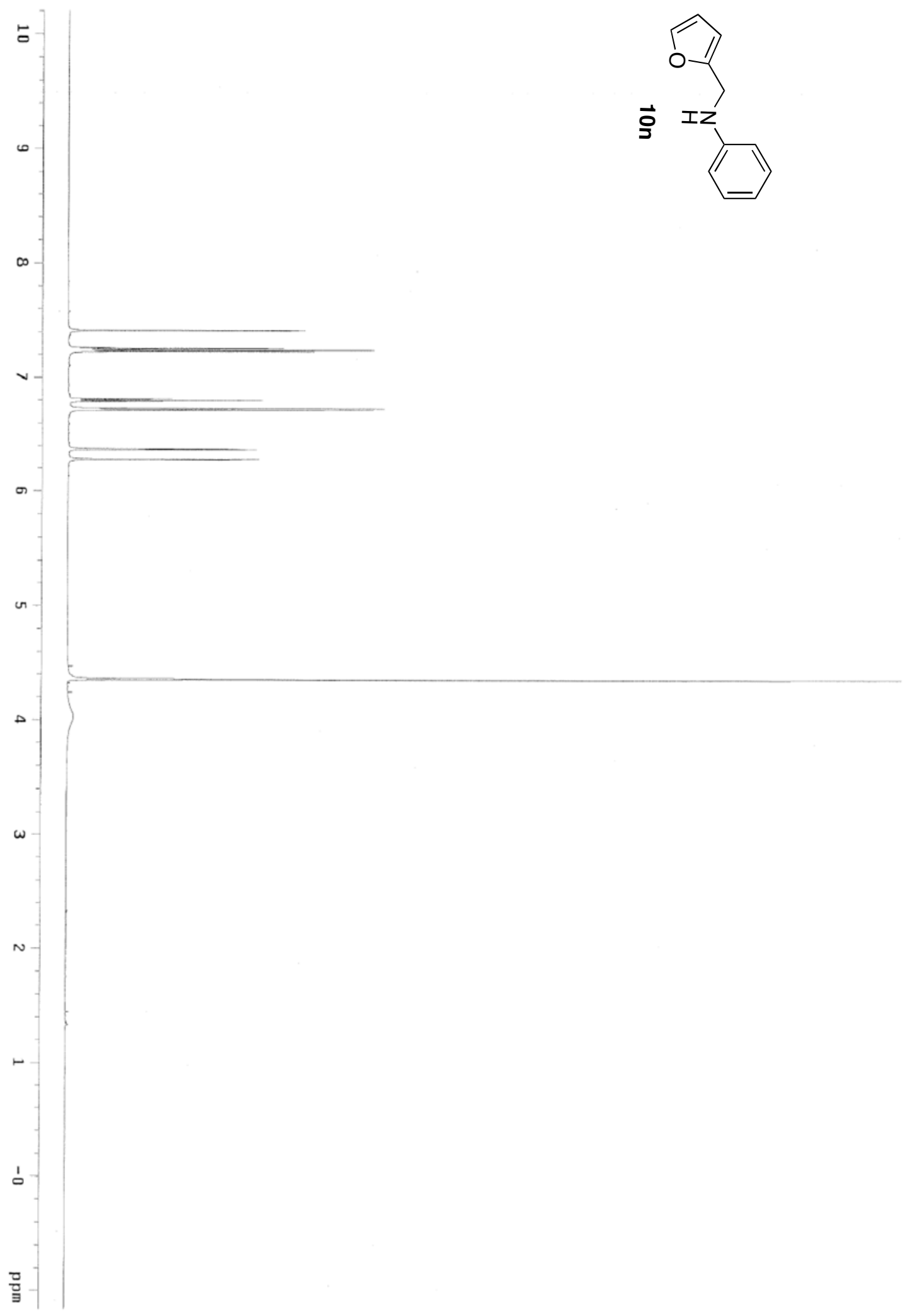




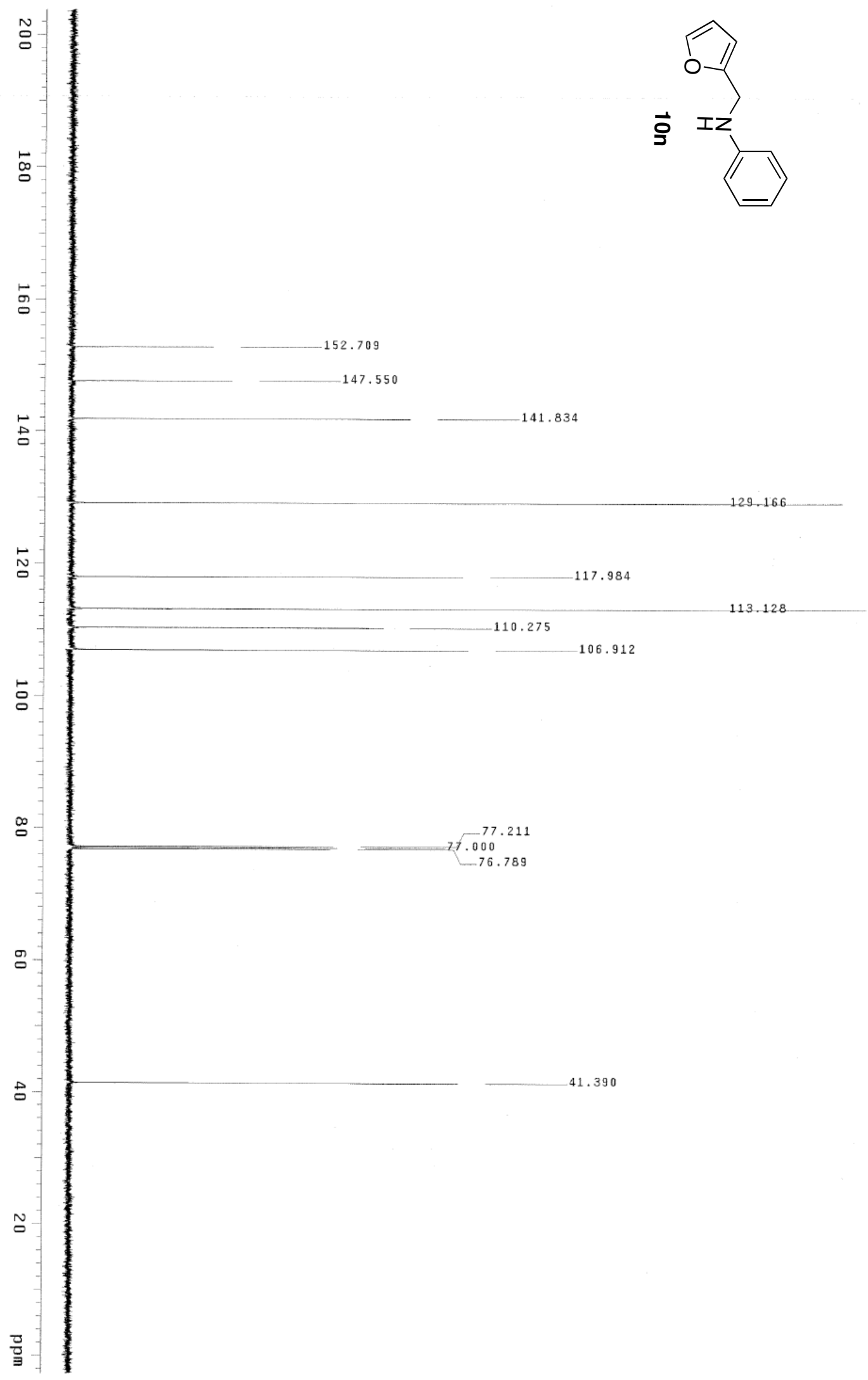




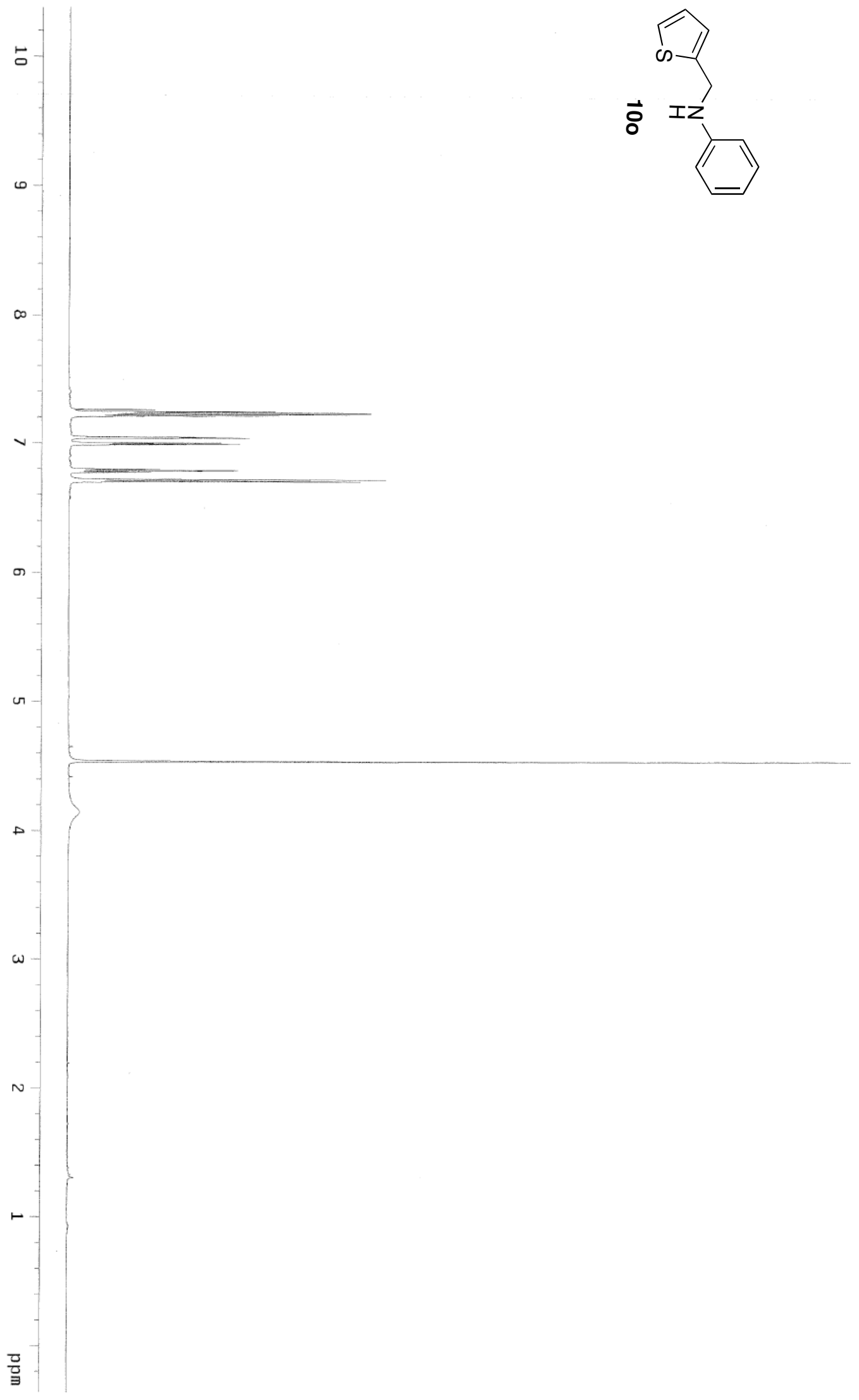




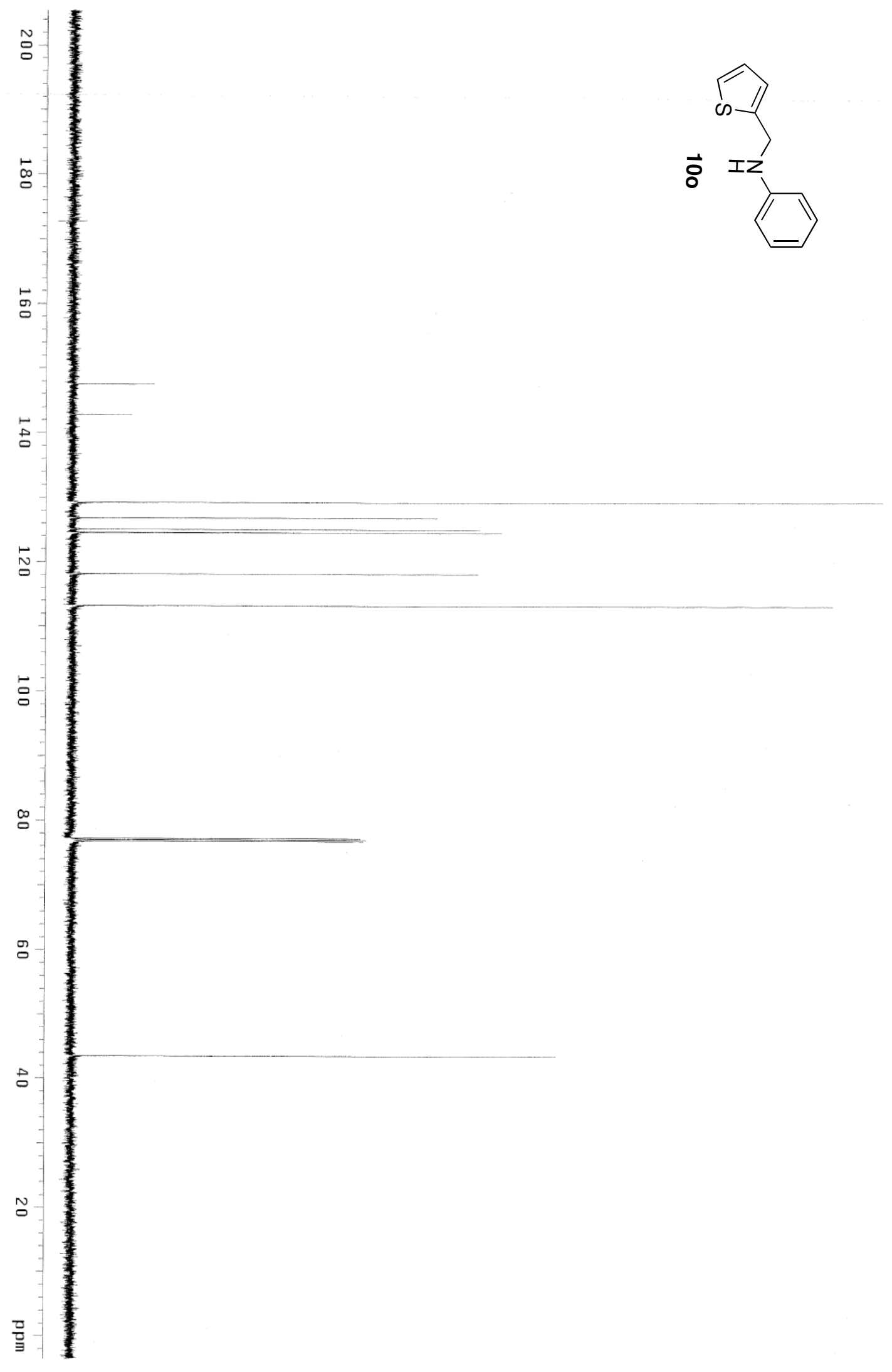




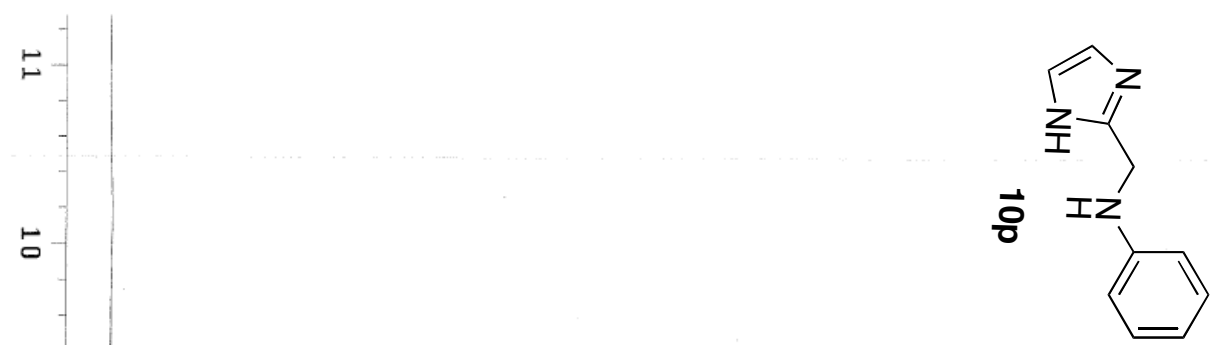

$\infty$
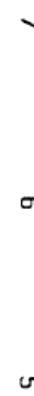

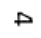

$\omega$

$N$

○

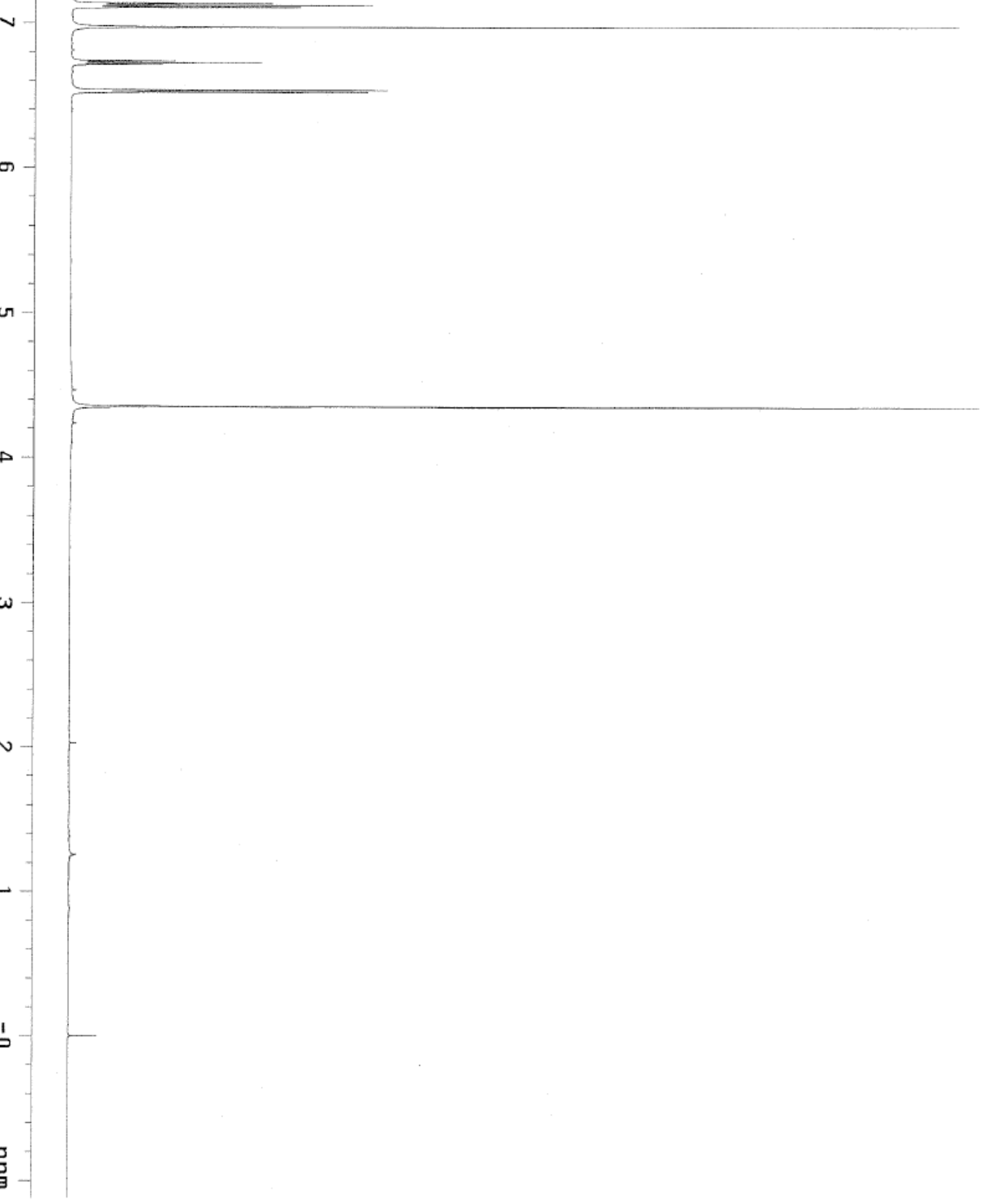




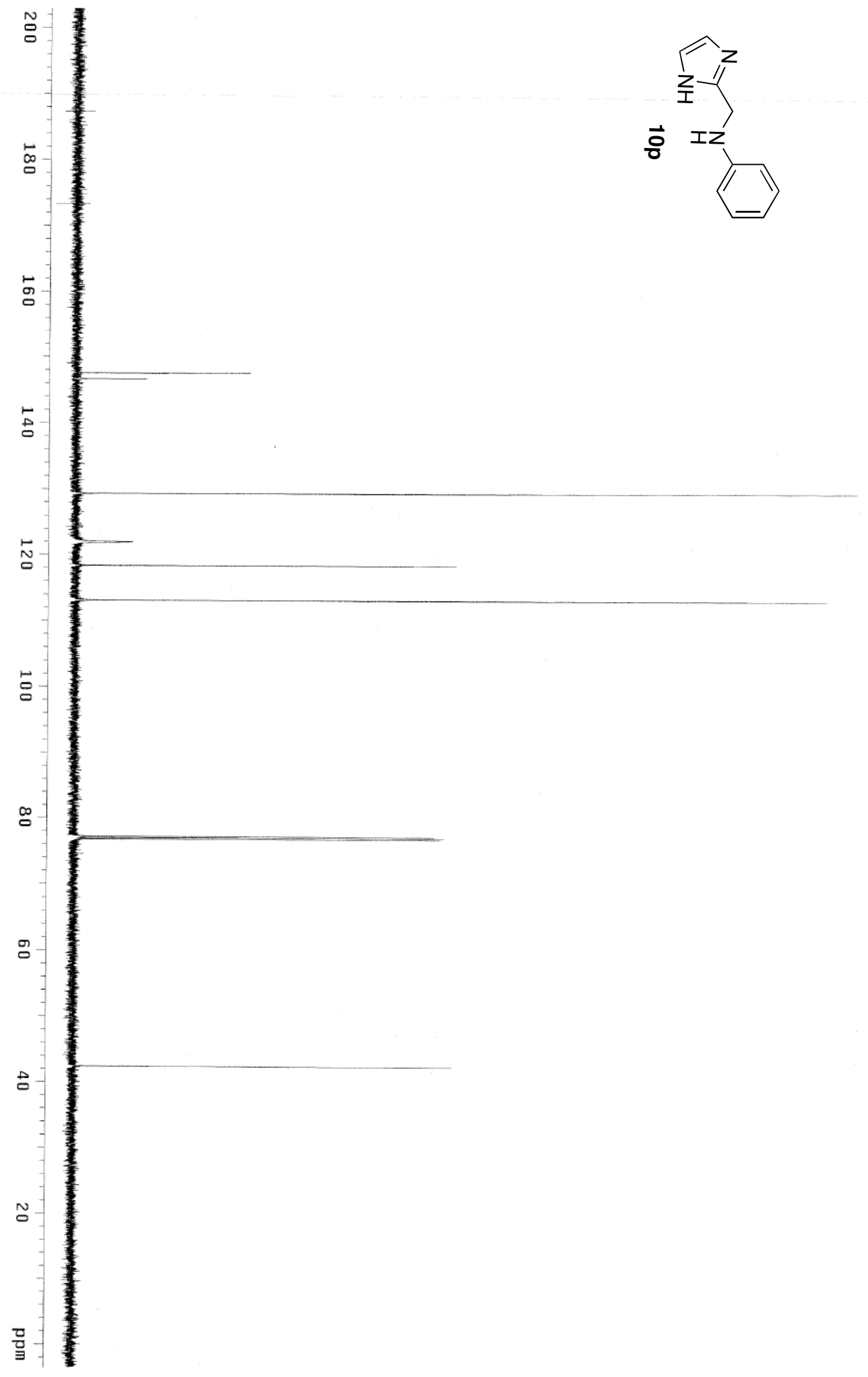



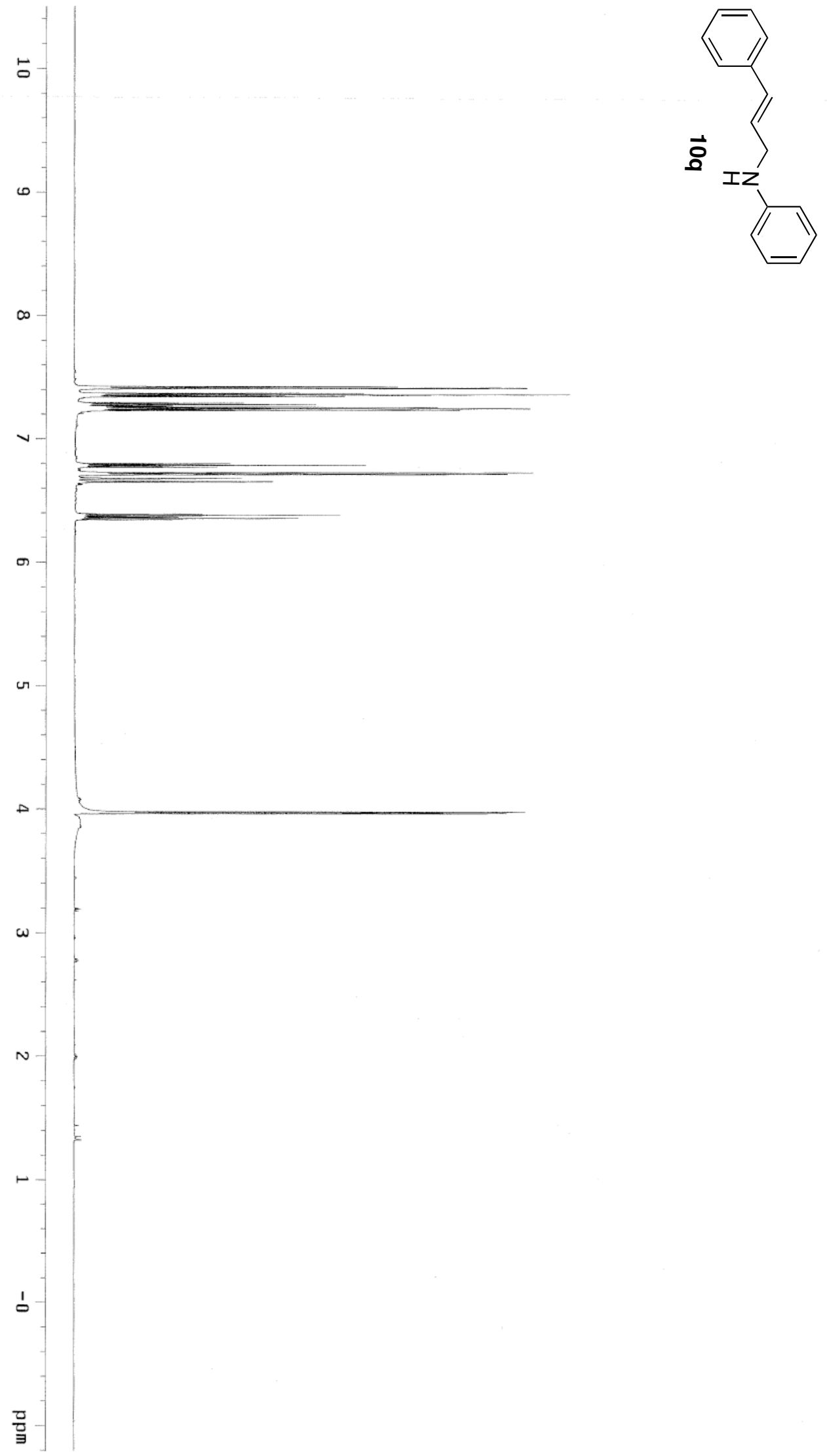


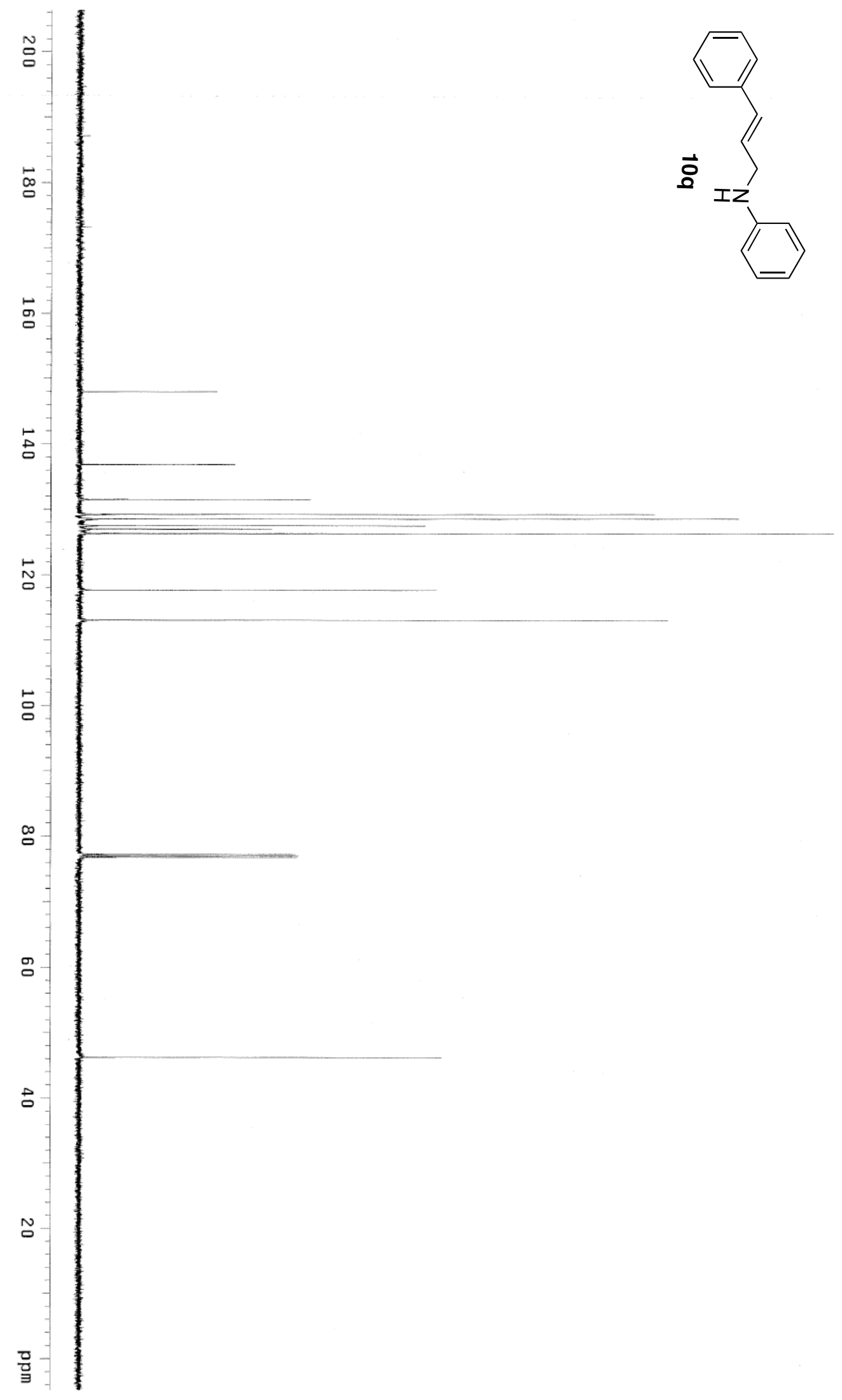




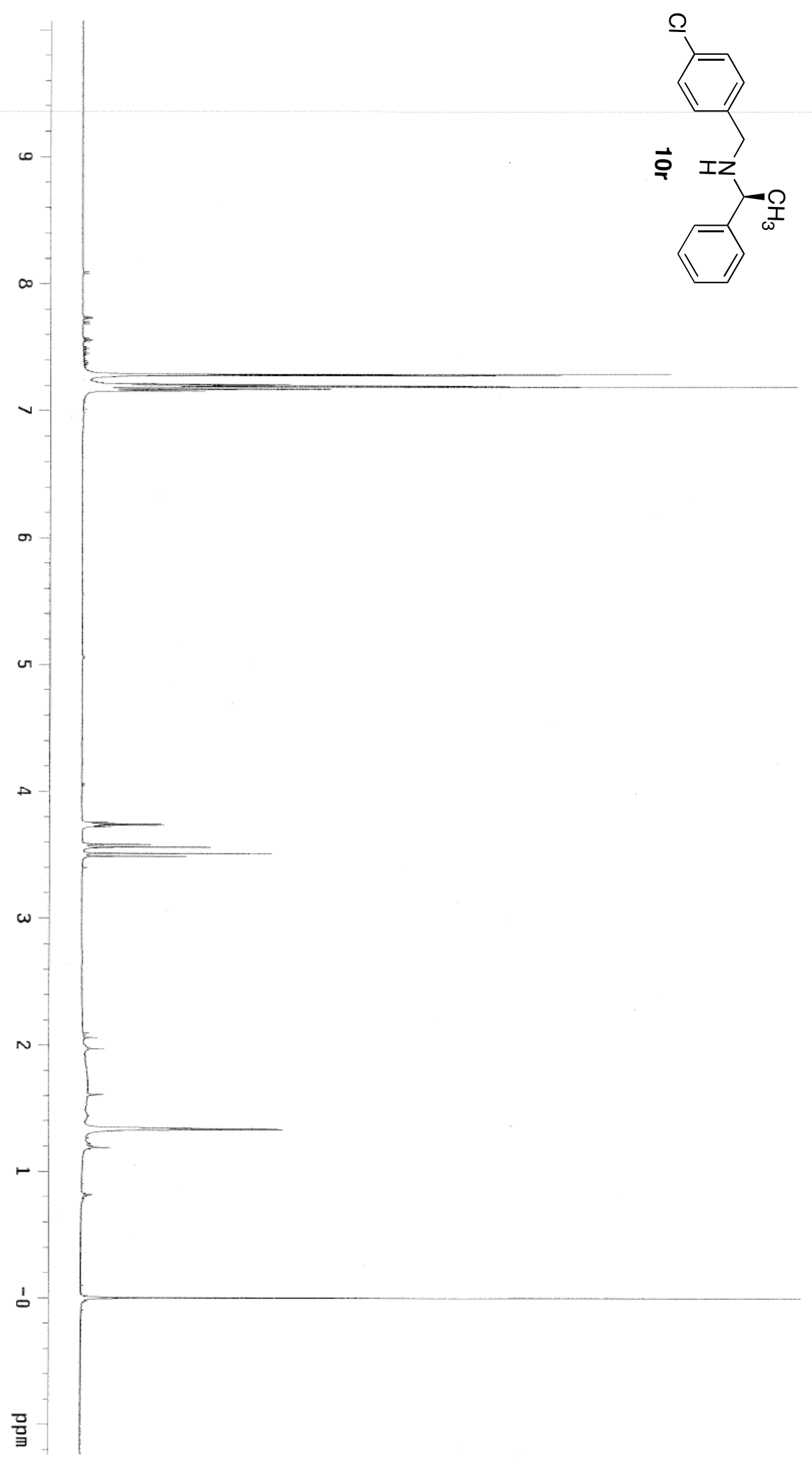




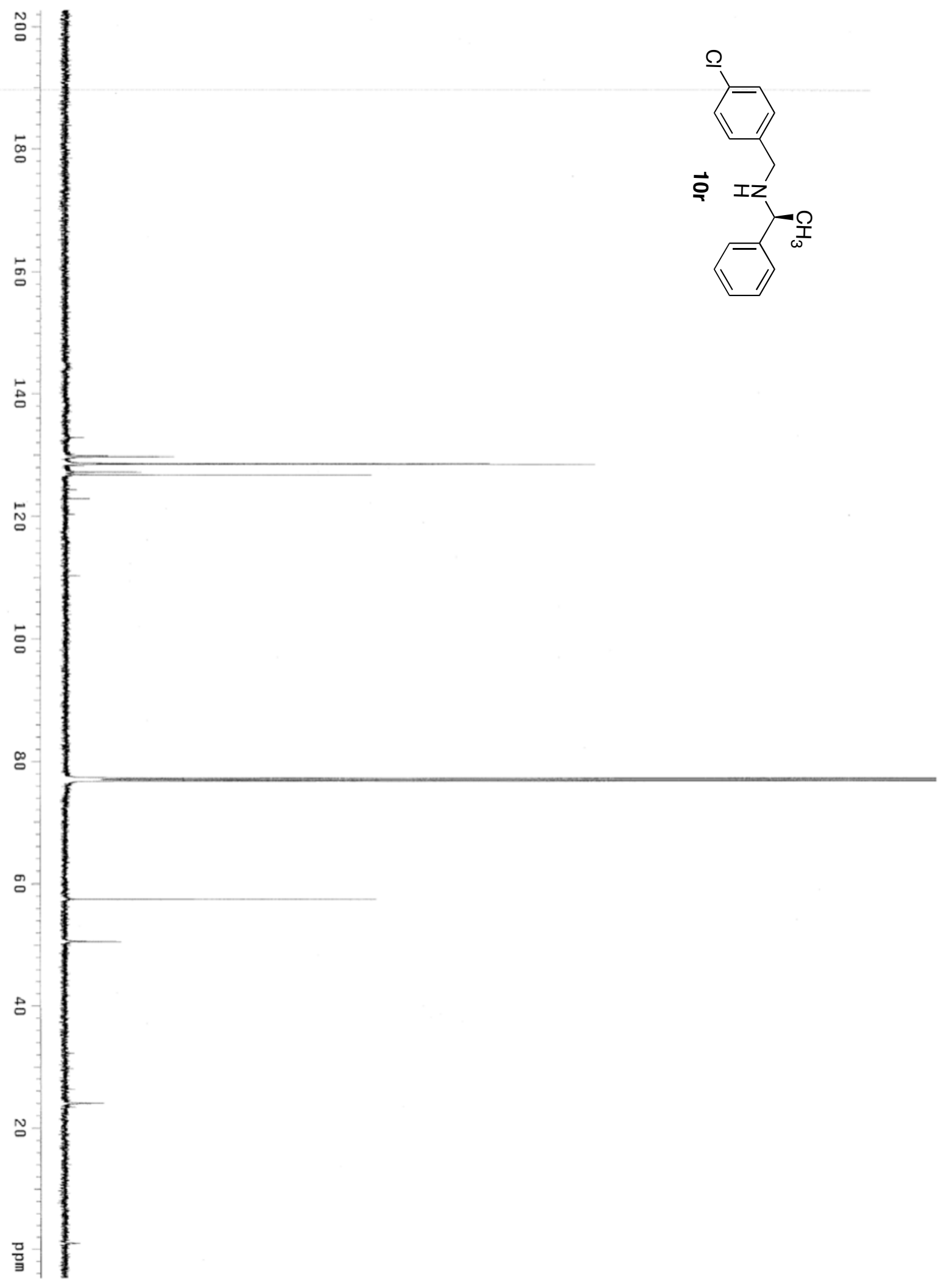




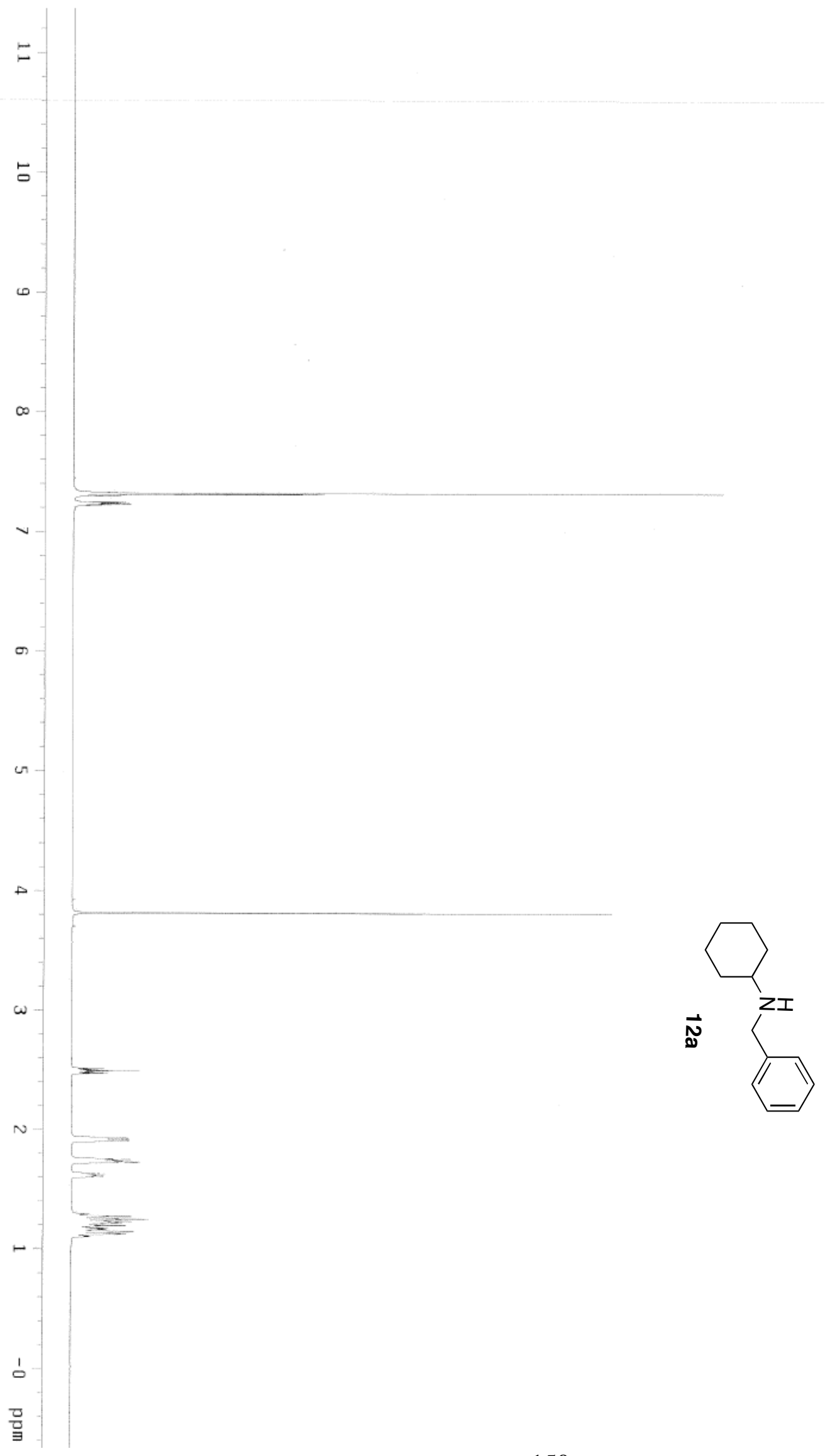




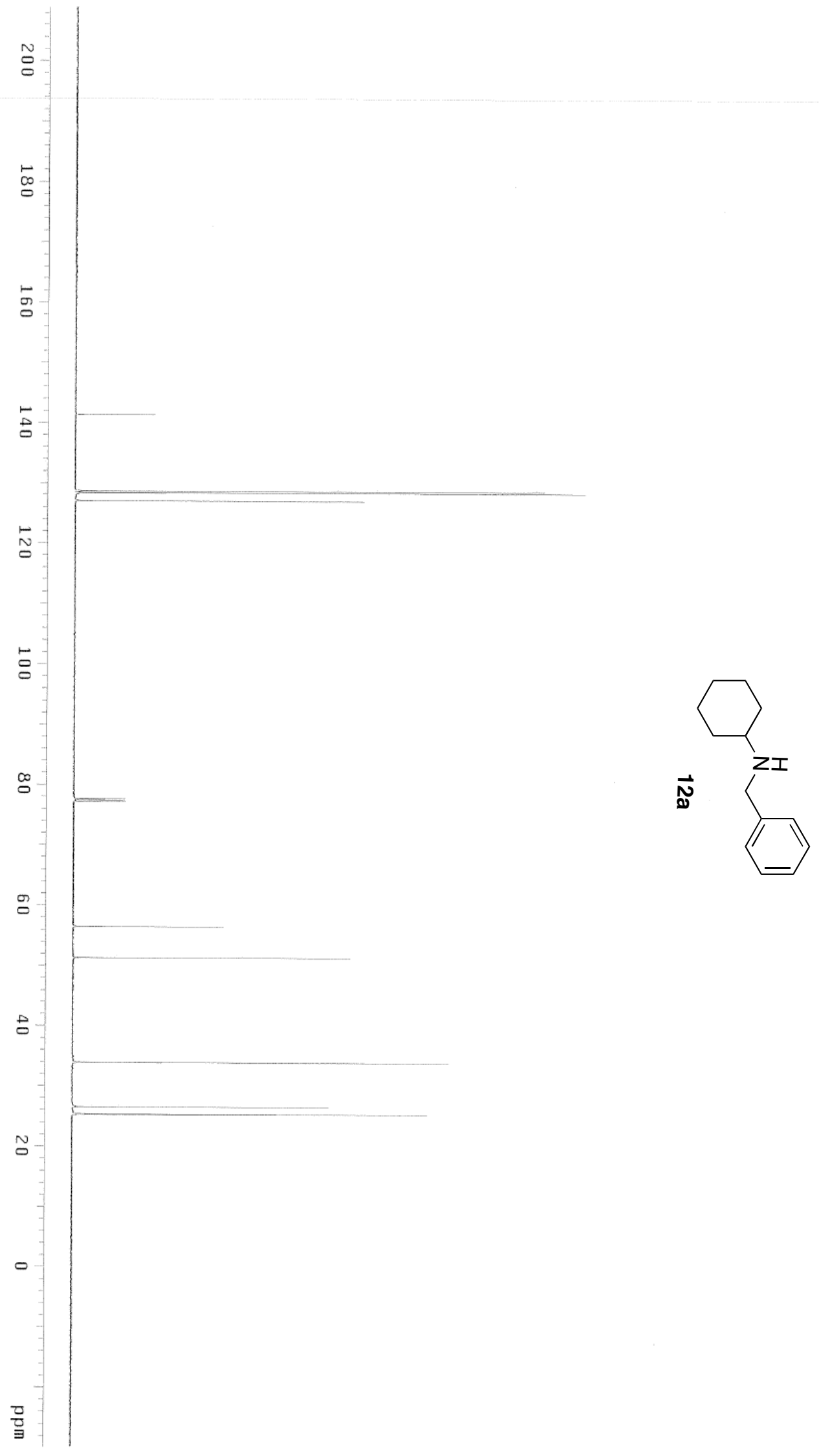




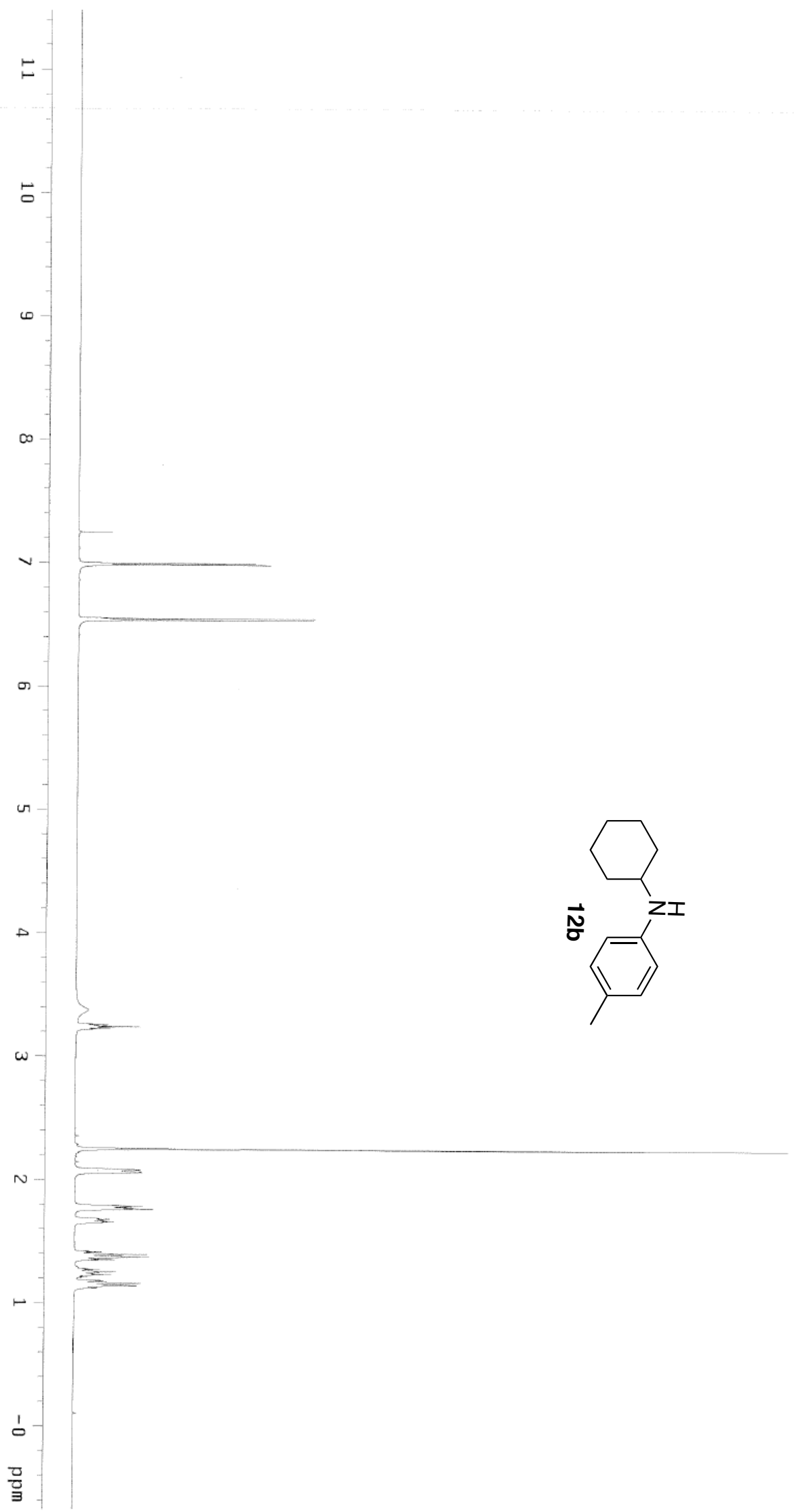




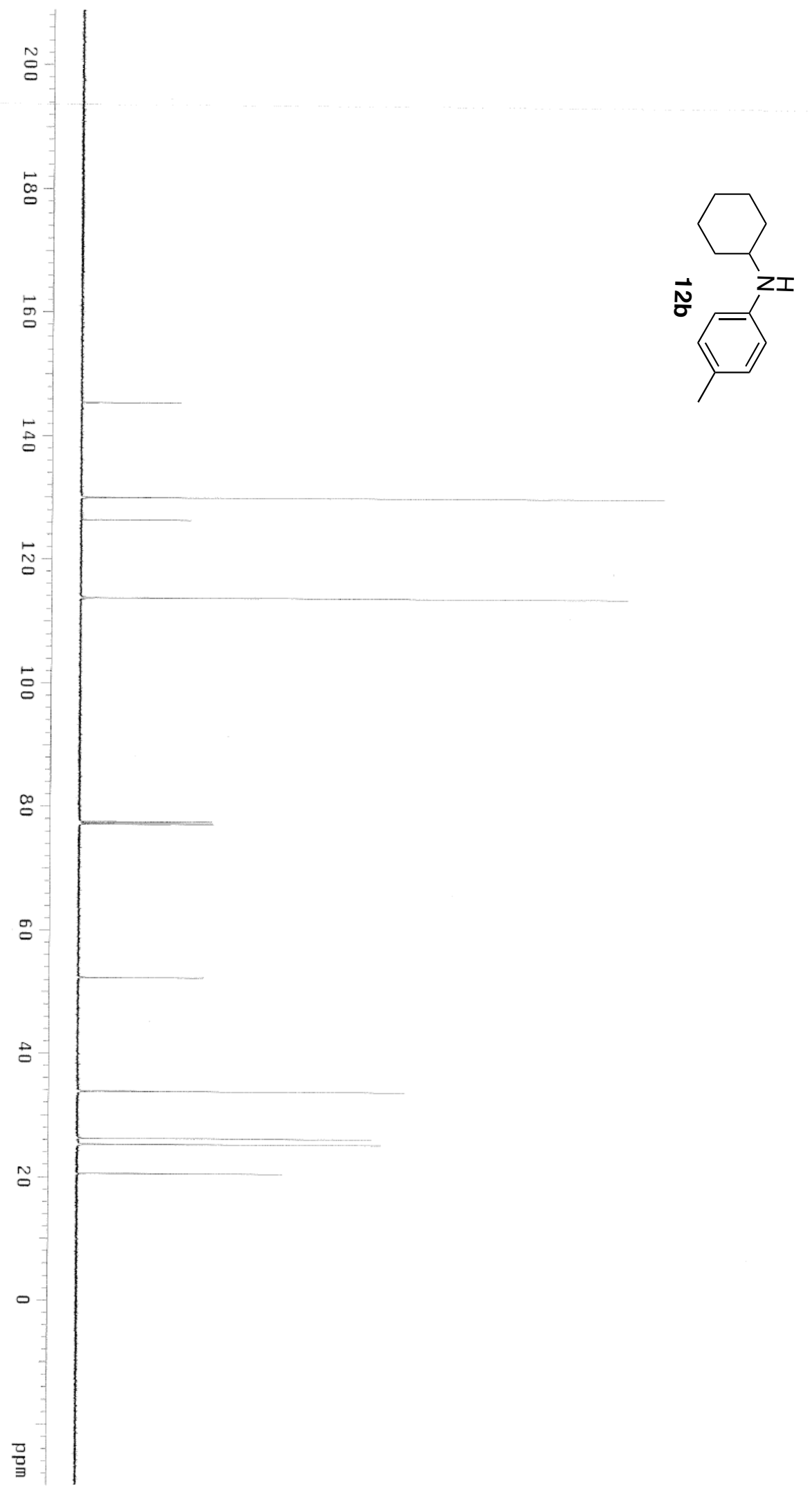




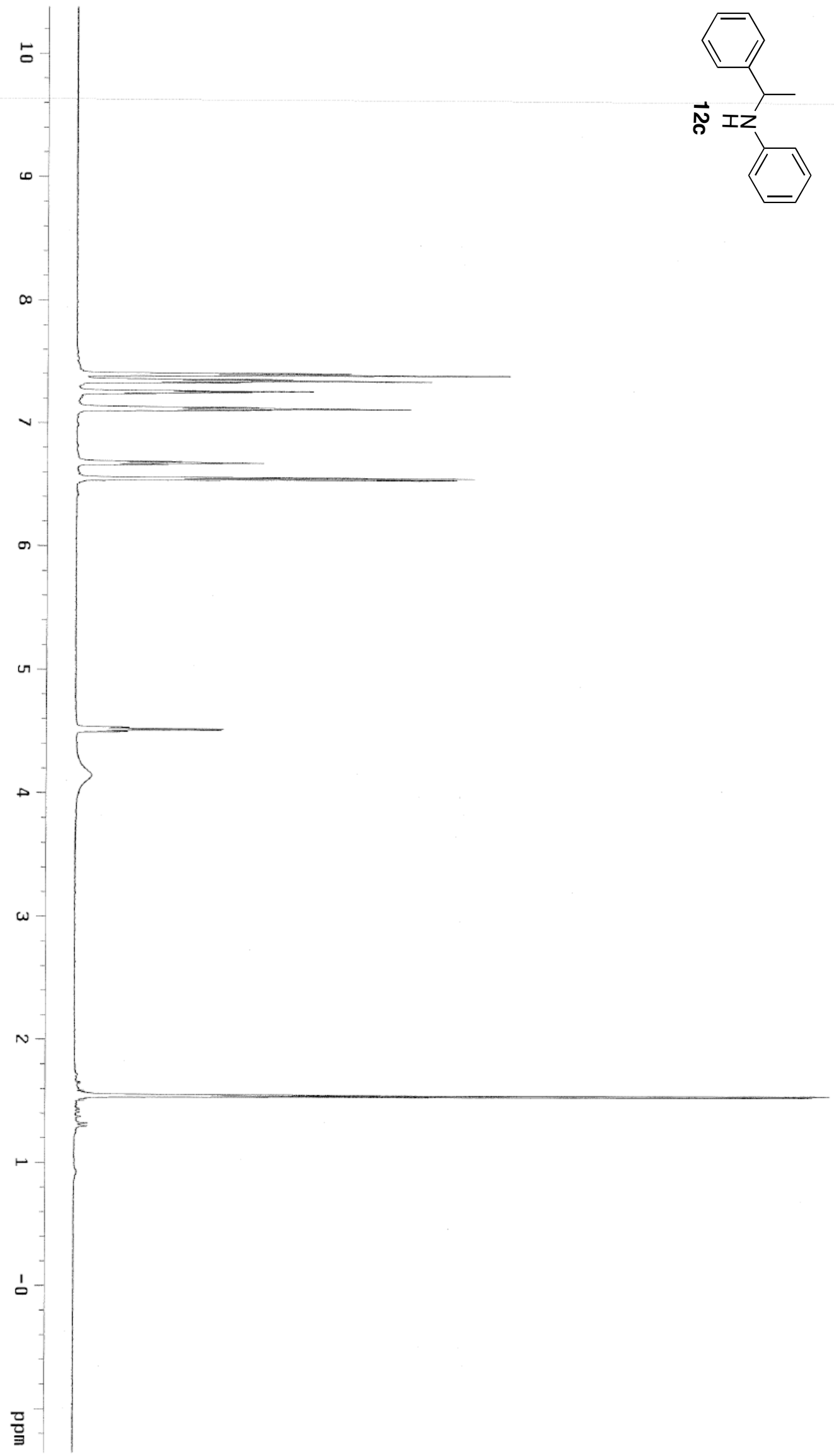




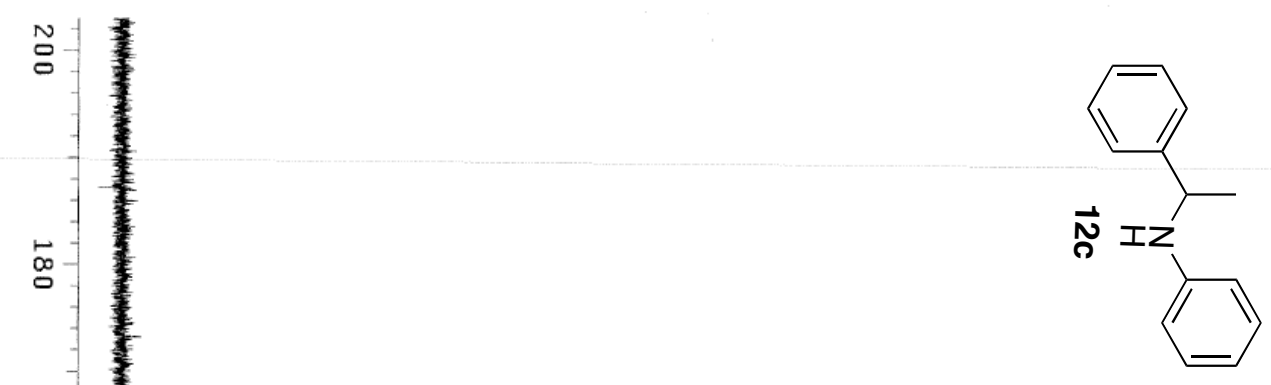

เ

$\stackrel{\square}{\square}$

ก

N-

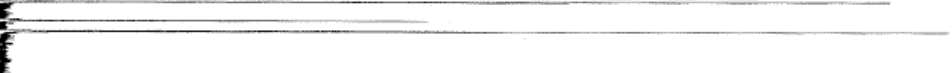

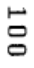

$\stackrel{\infty}{\circ-1}$

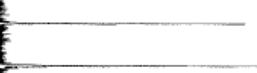

雍

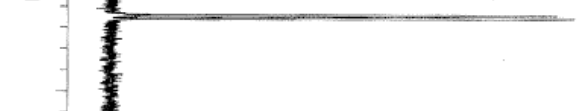

엄

ㅁ

.

$\therefore$

믐 


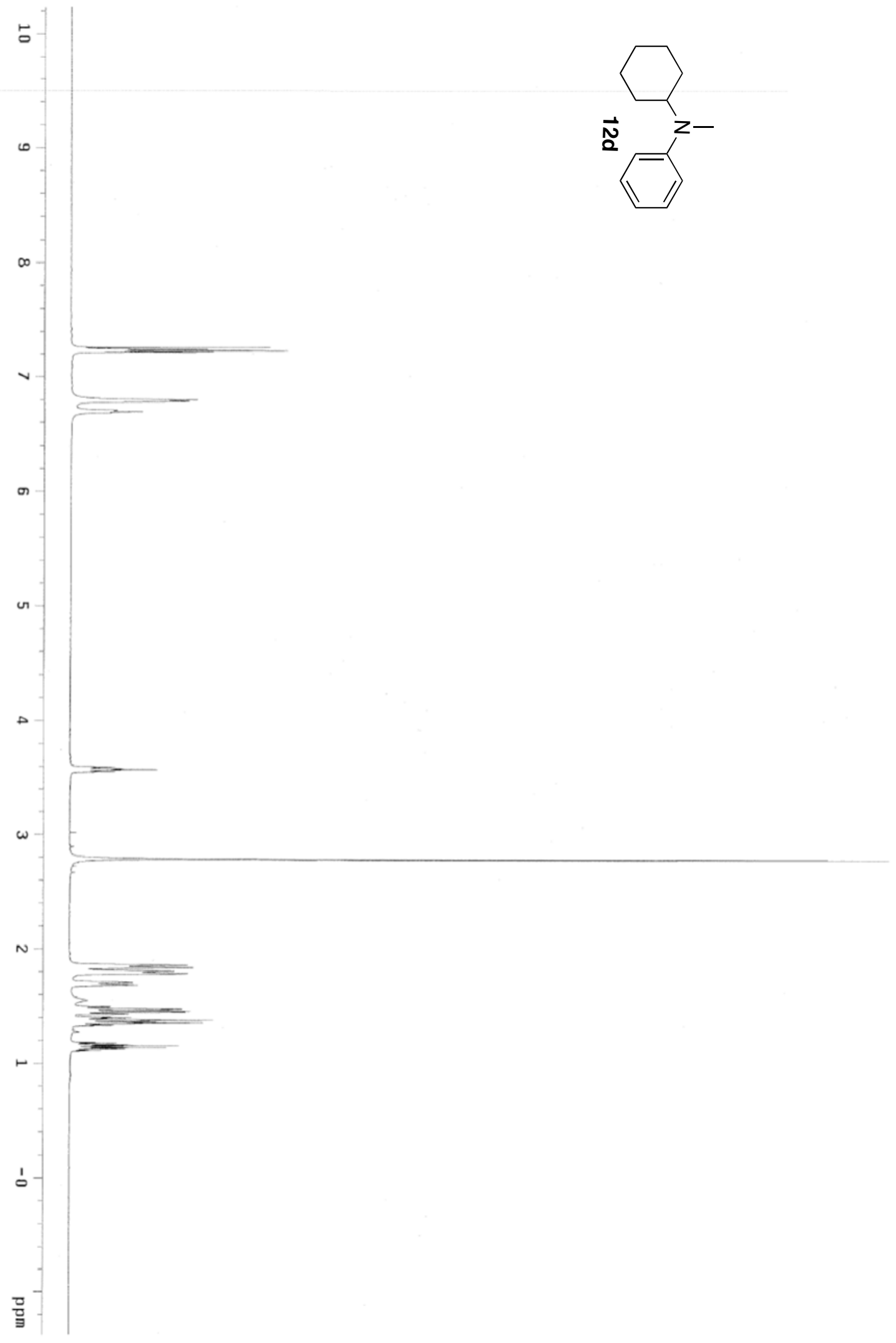




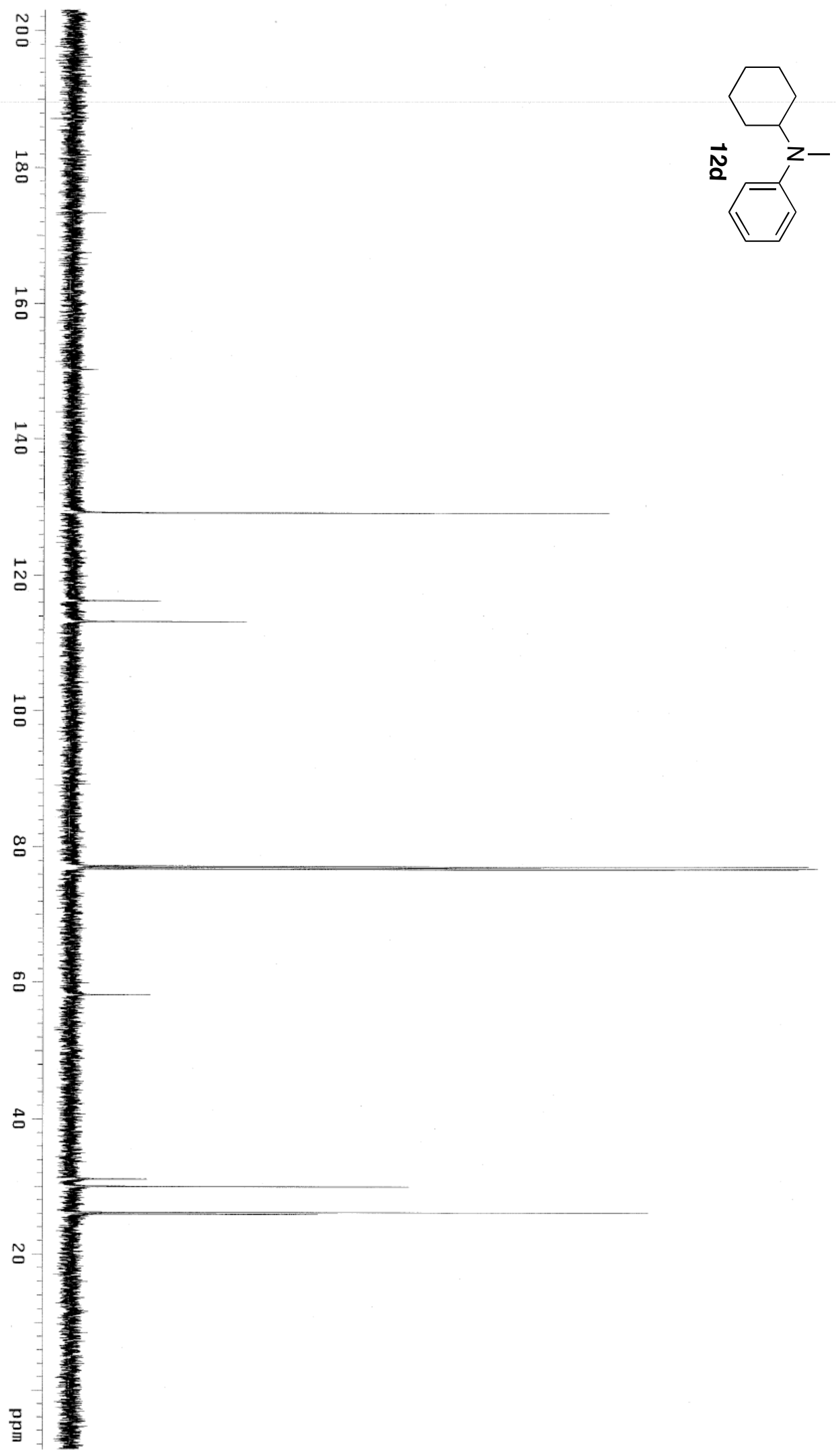




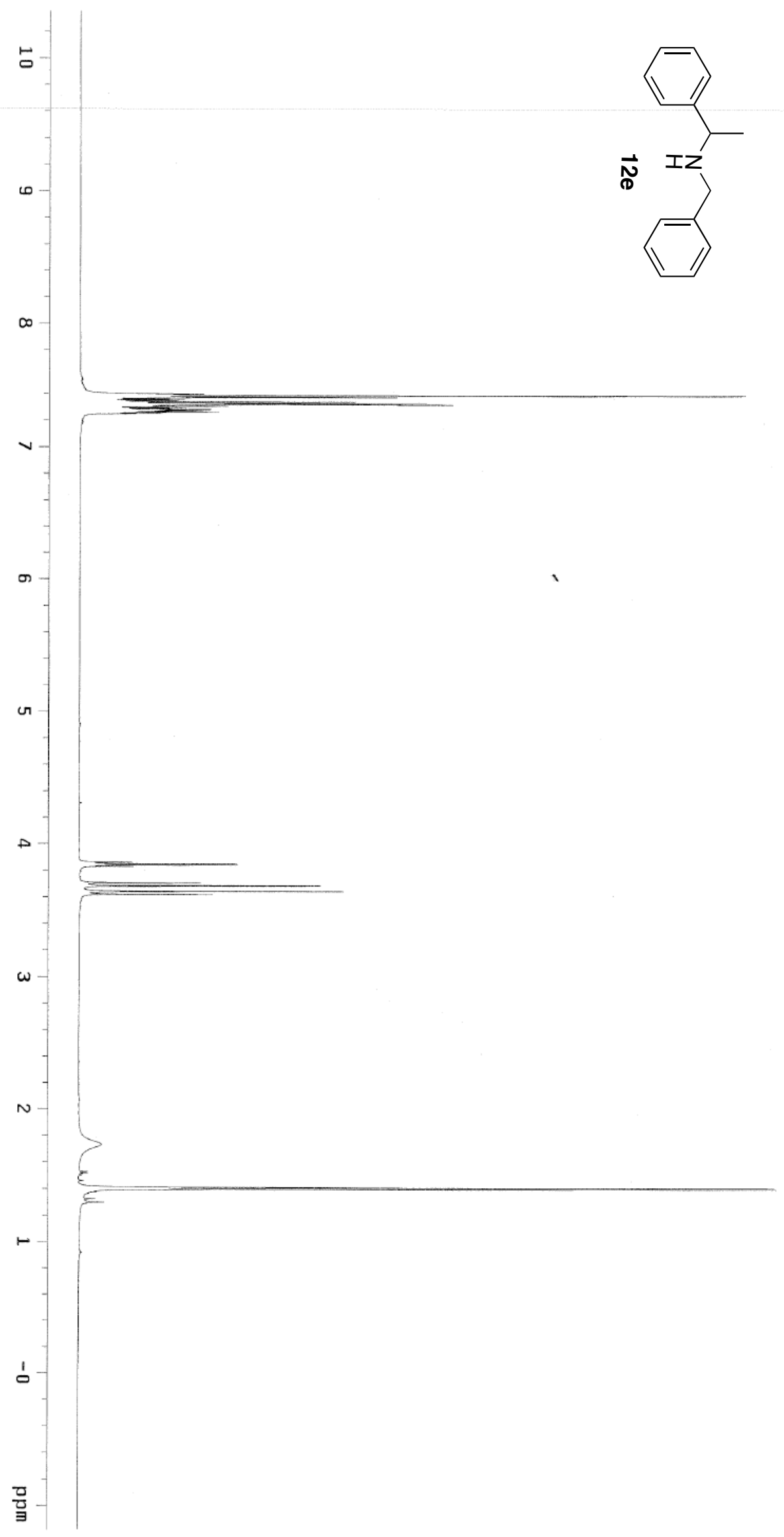




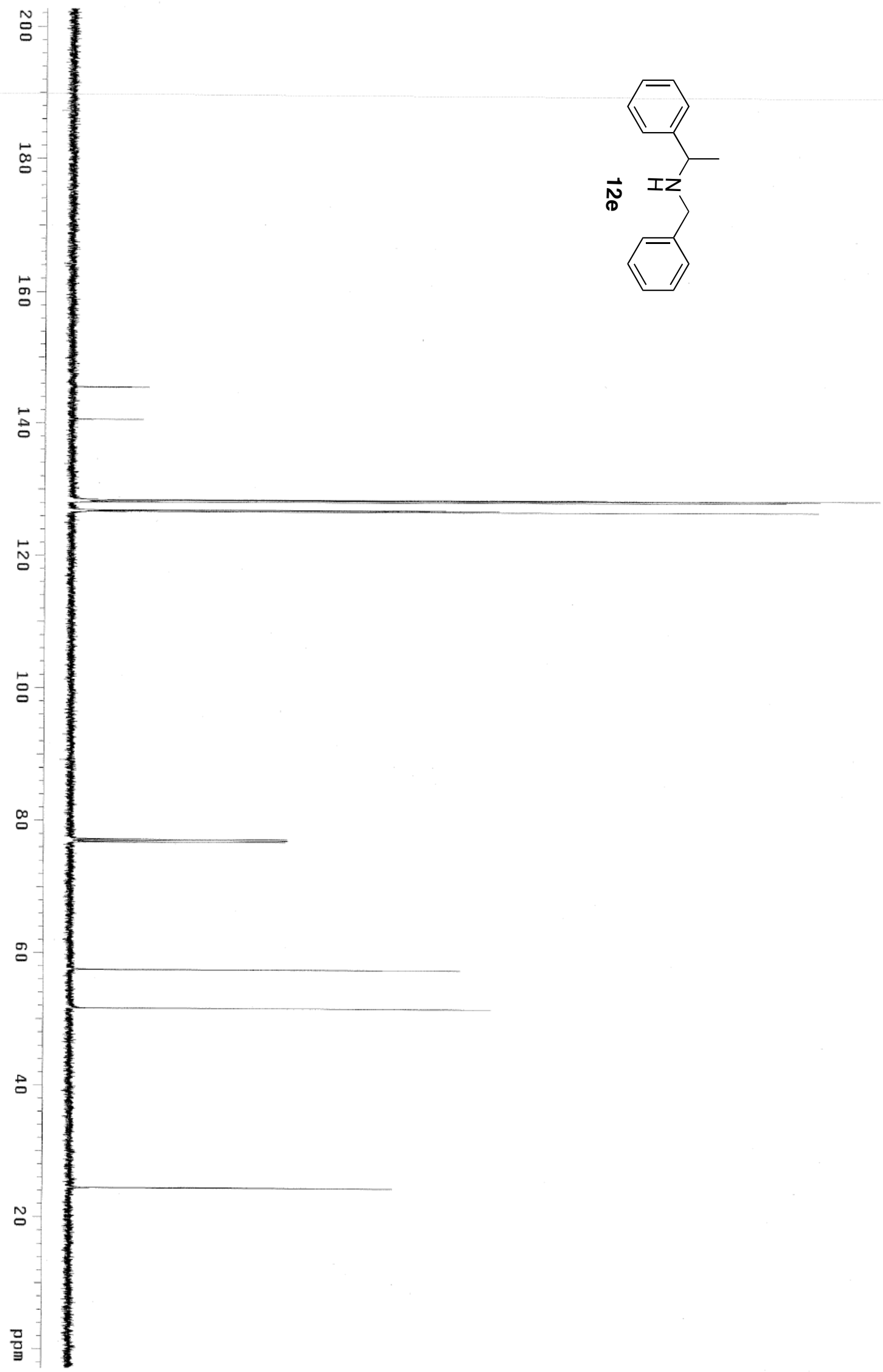




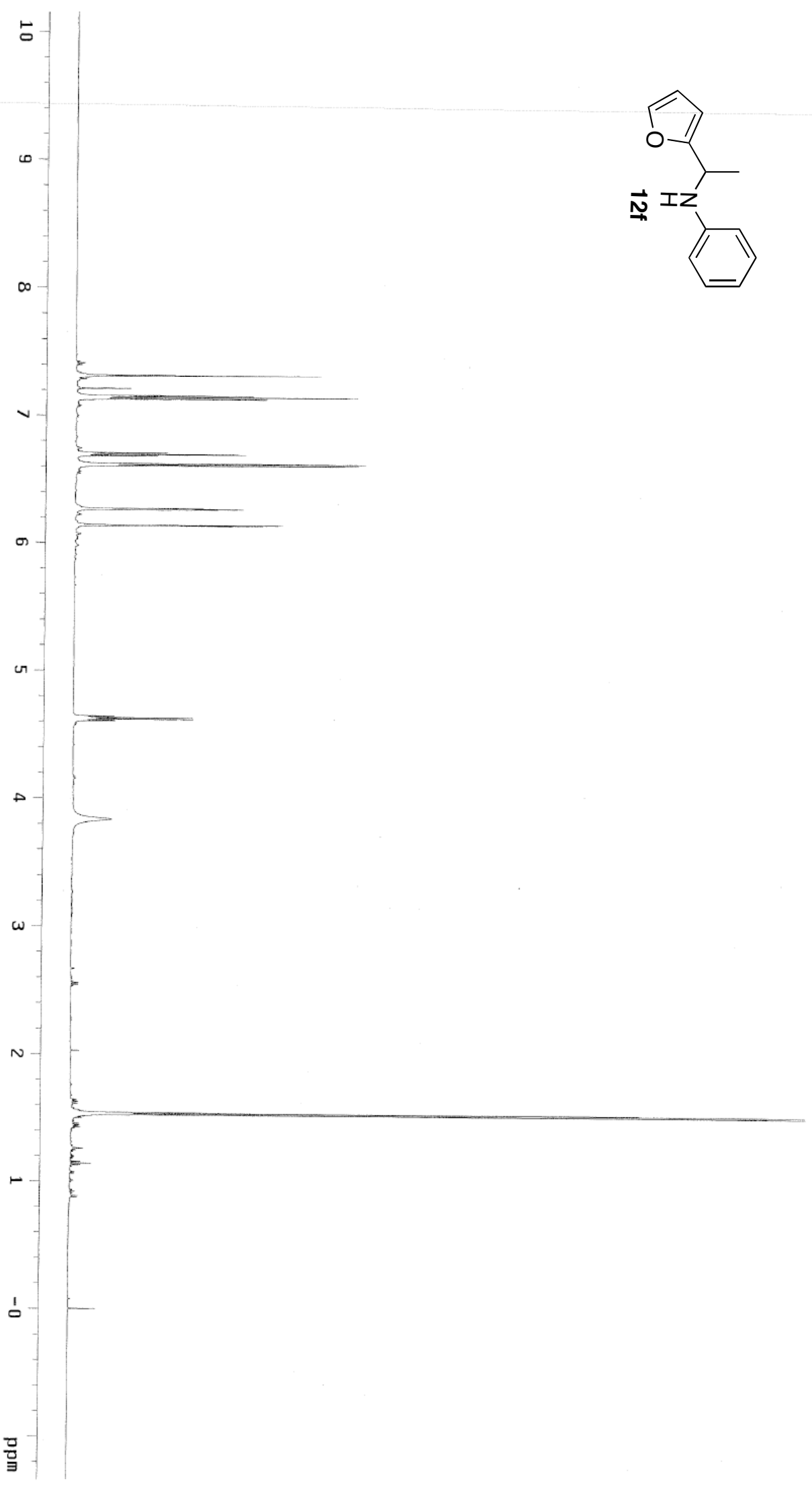




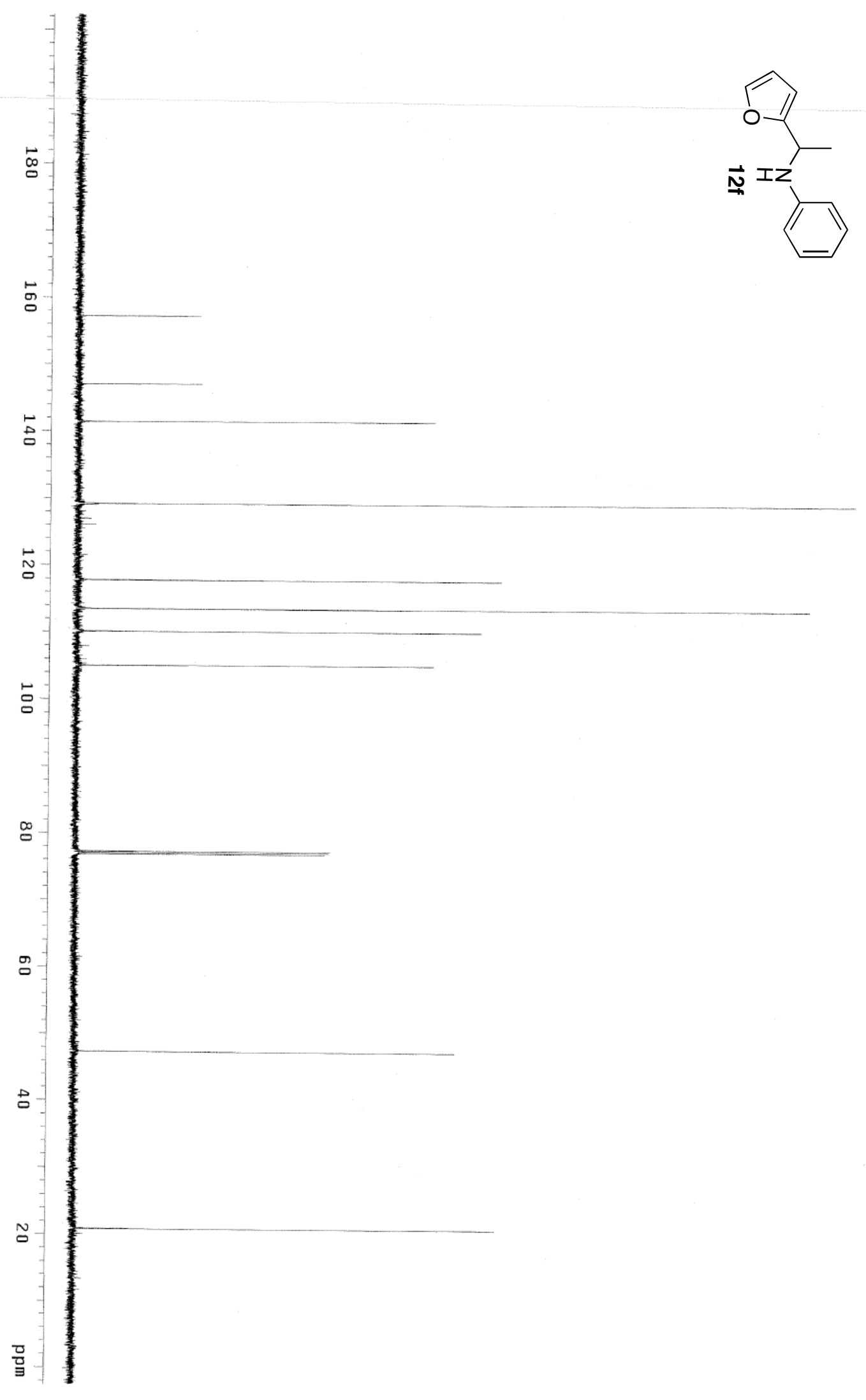




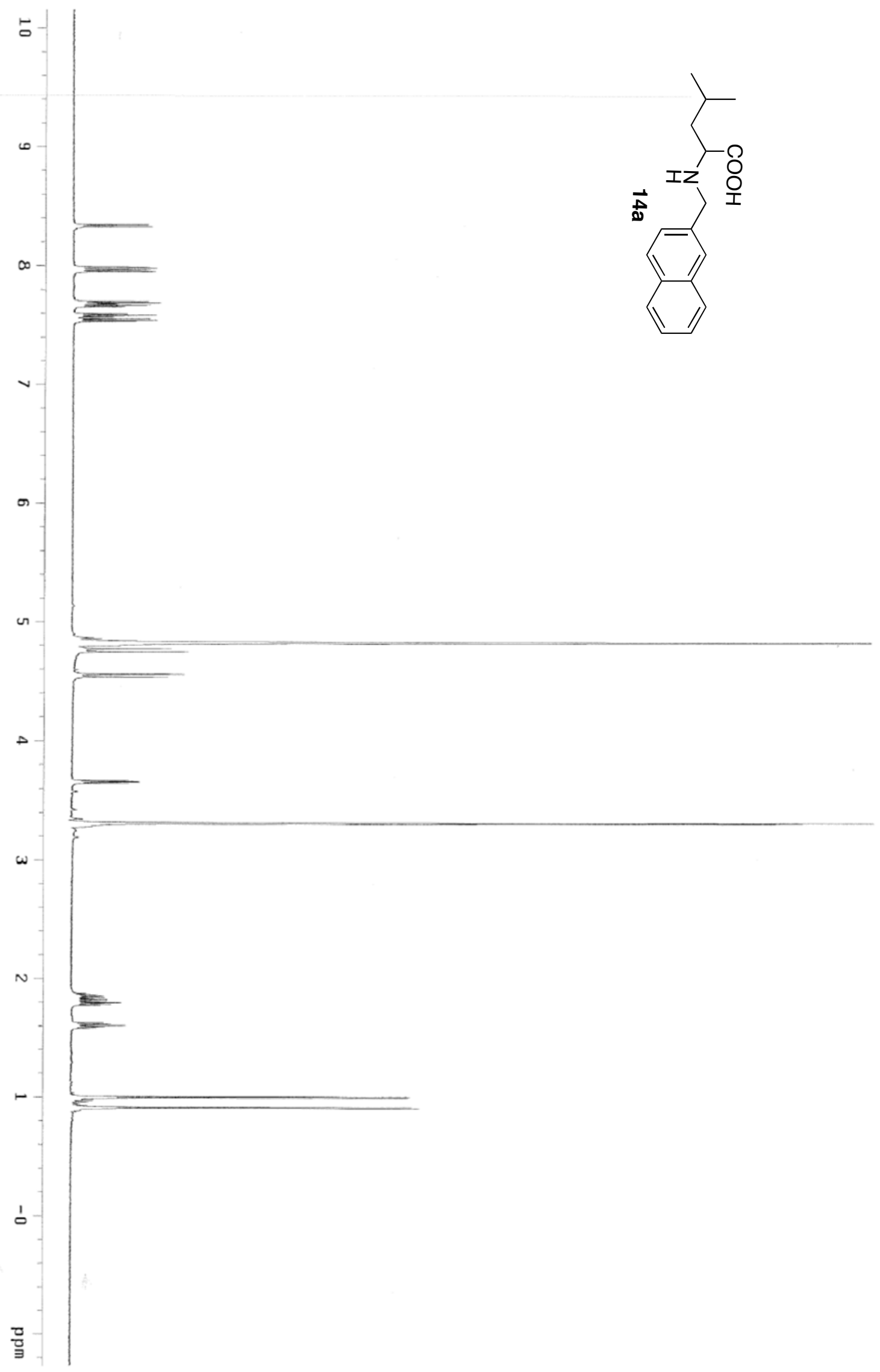




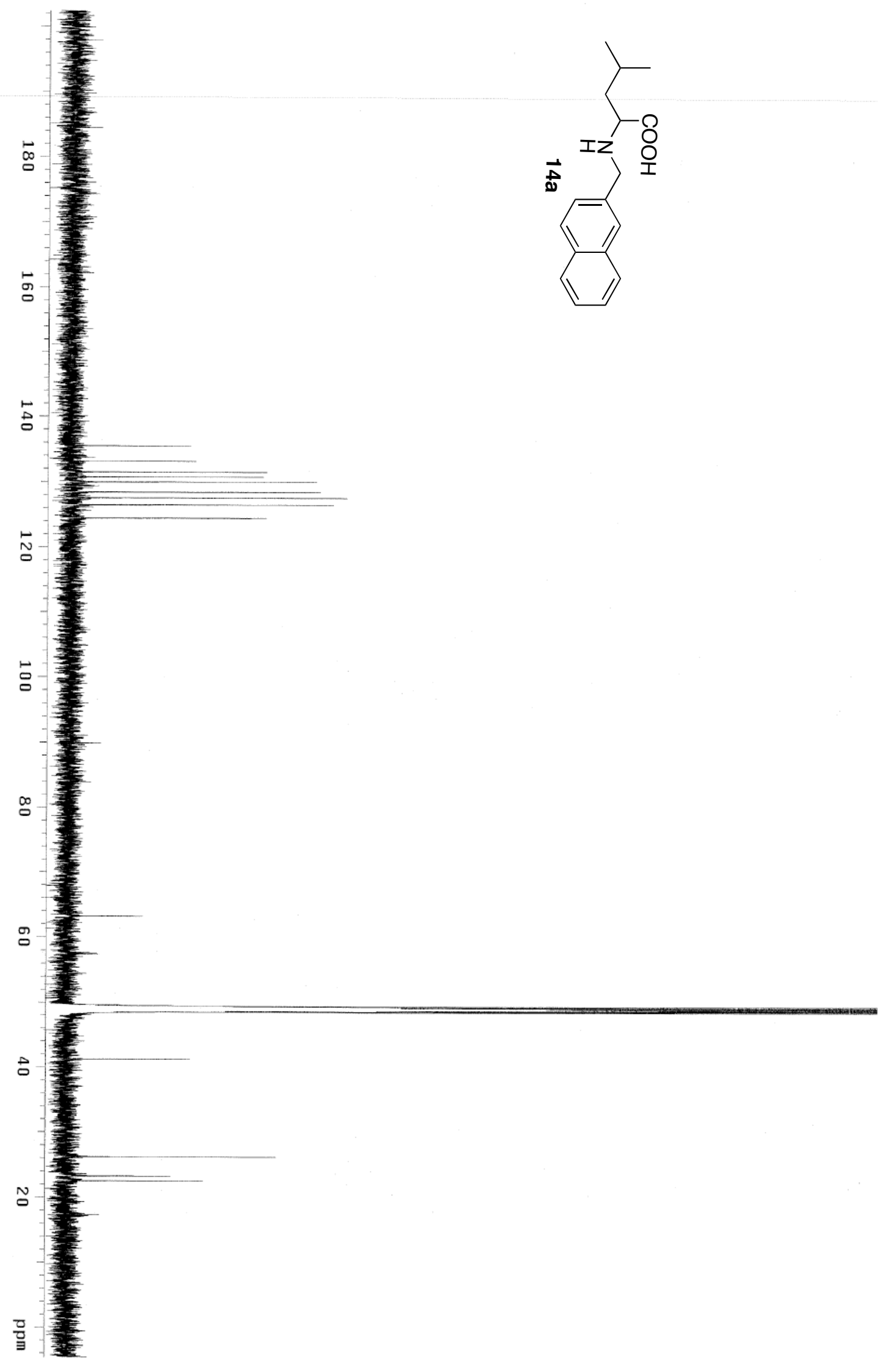




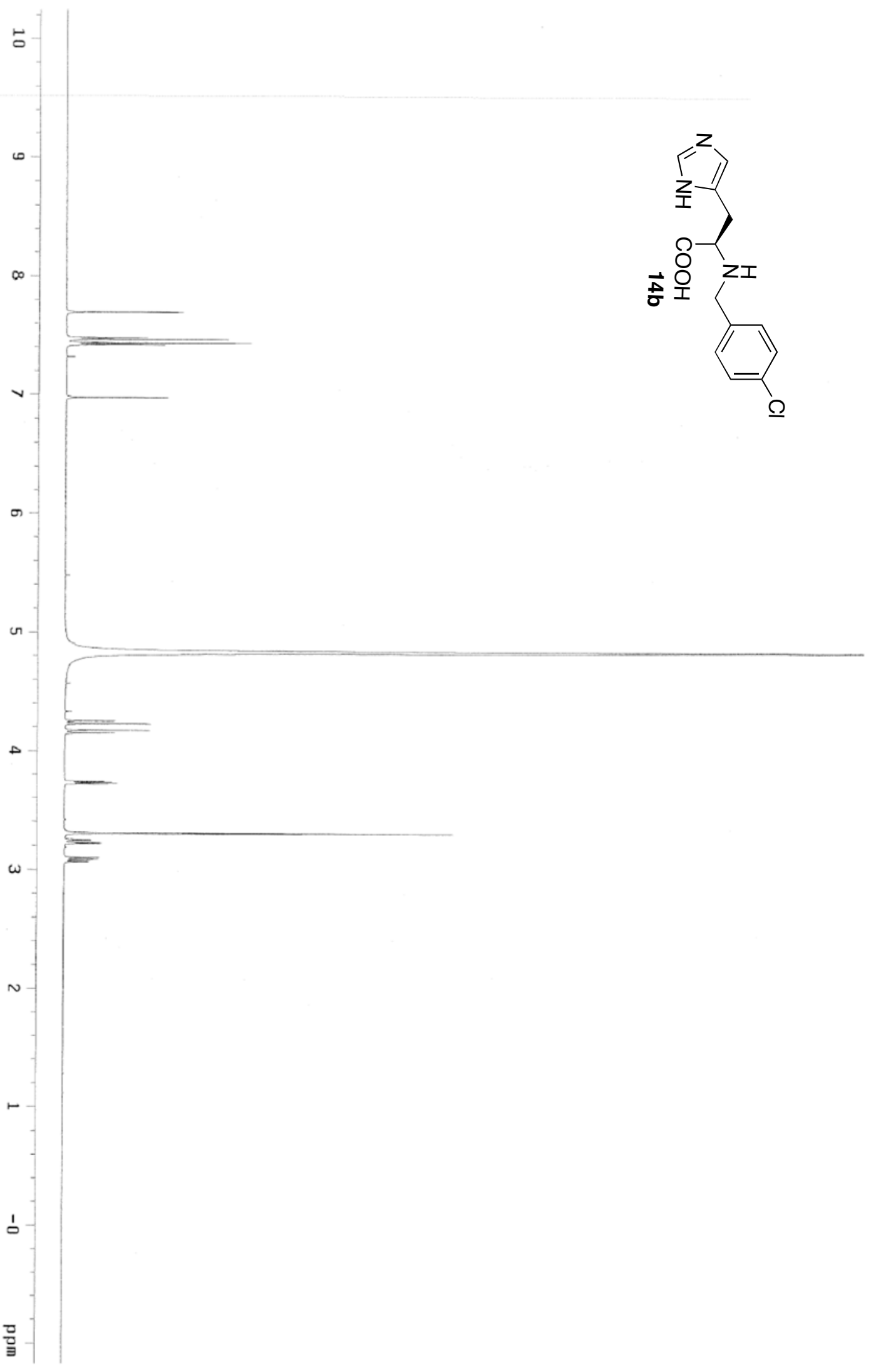




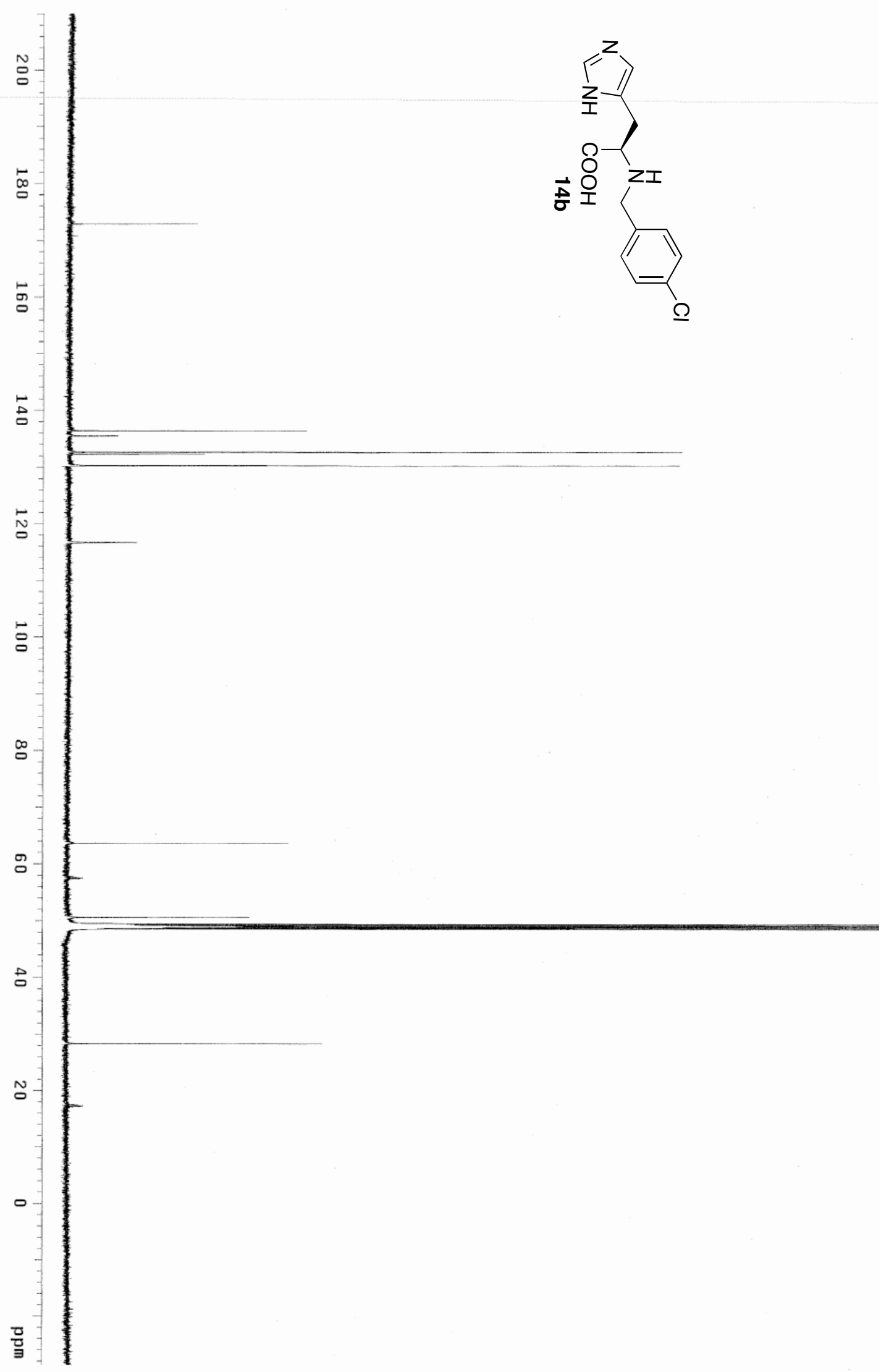




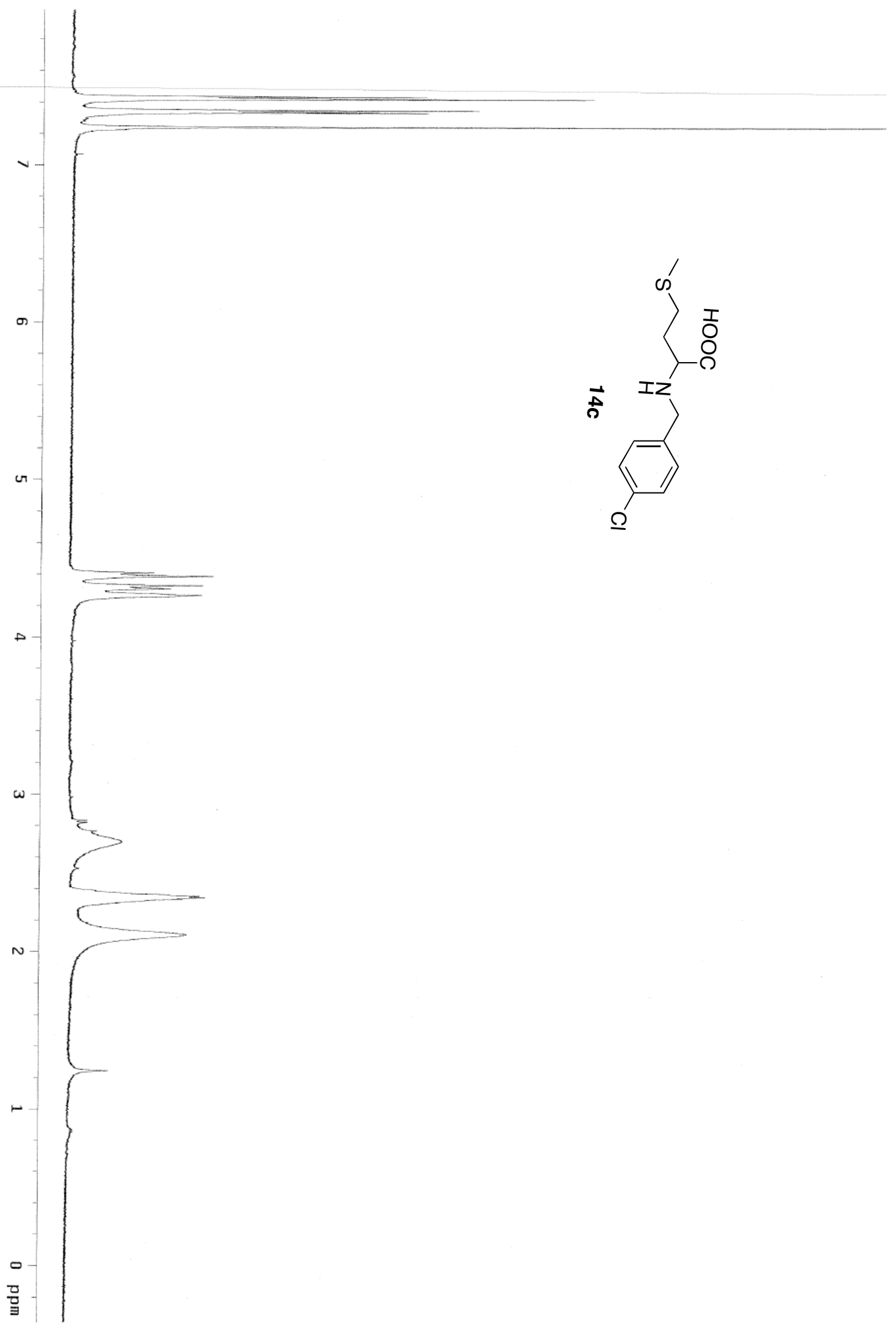




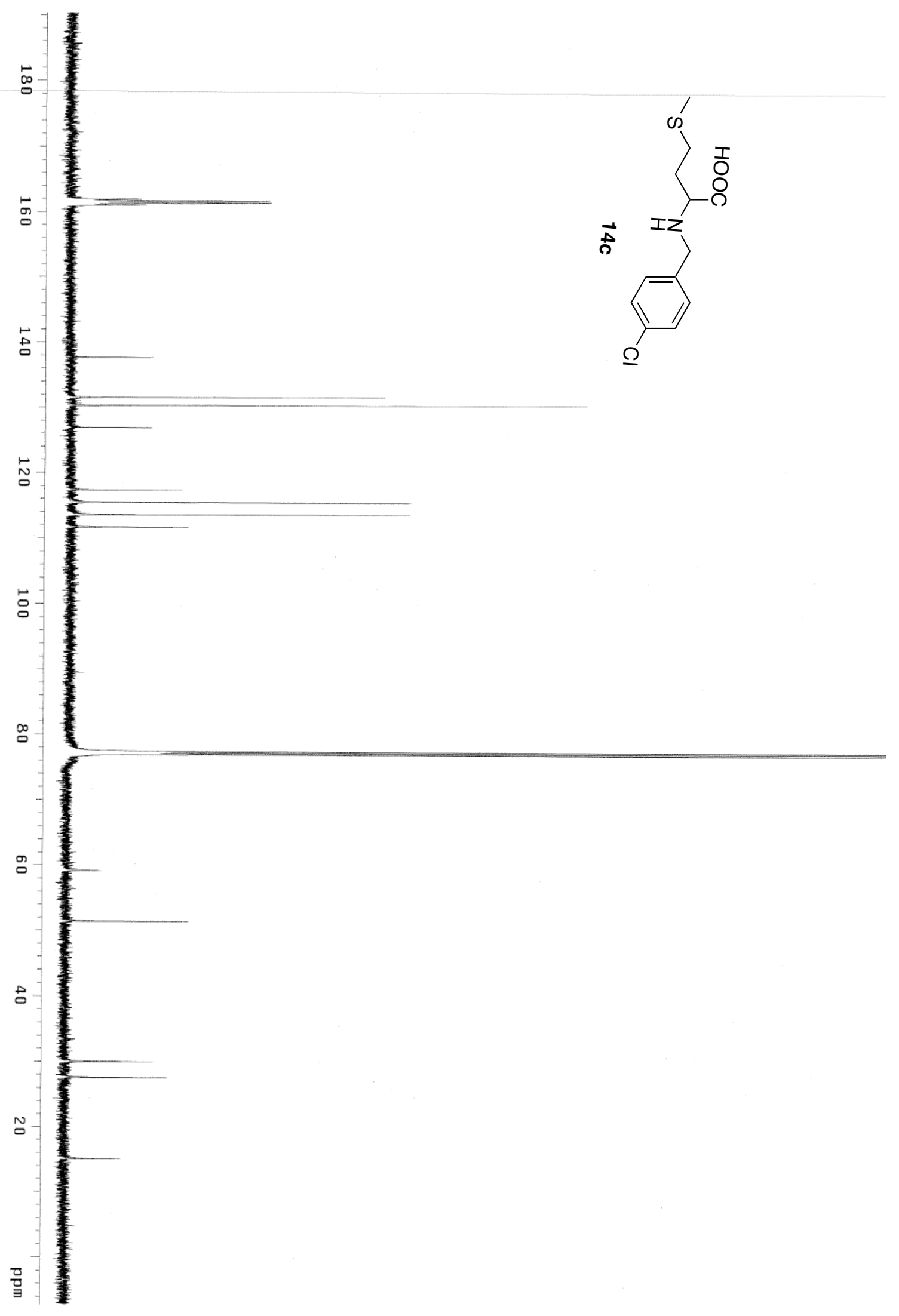




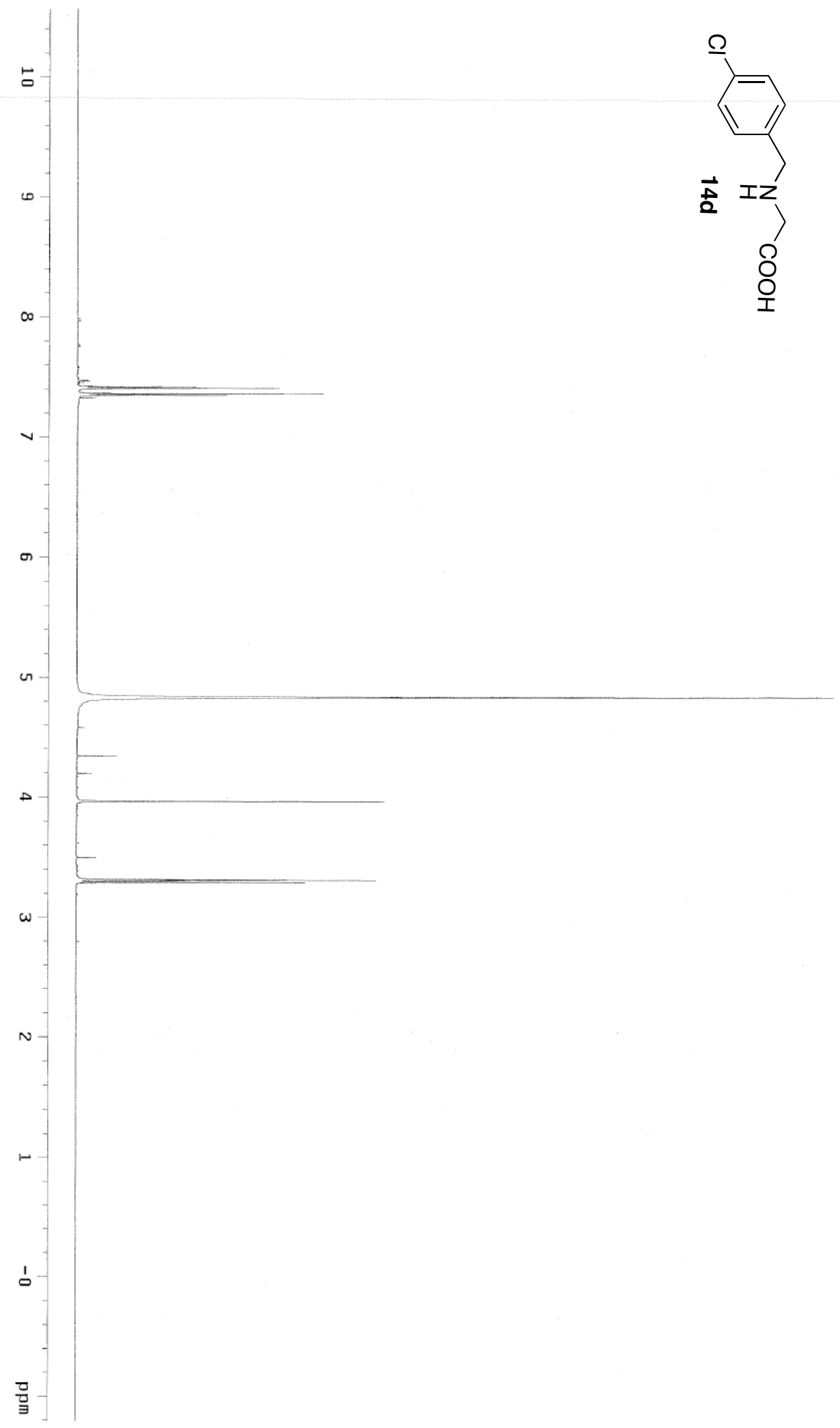




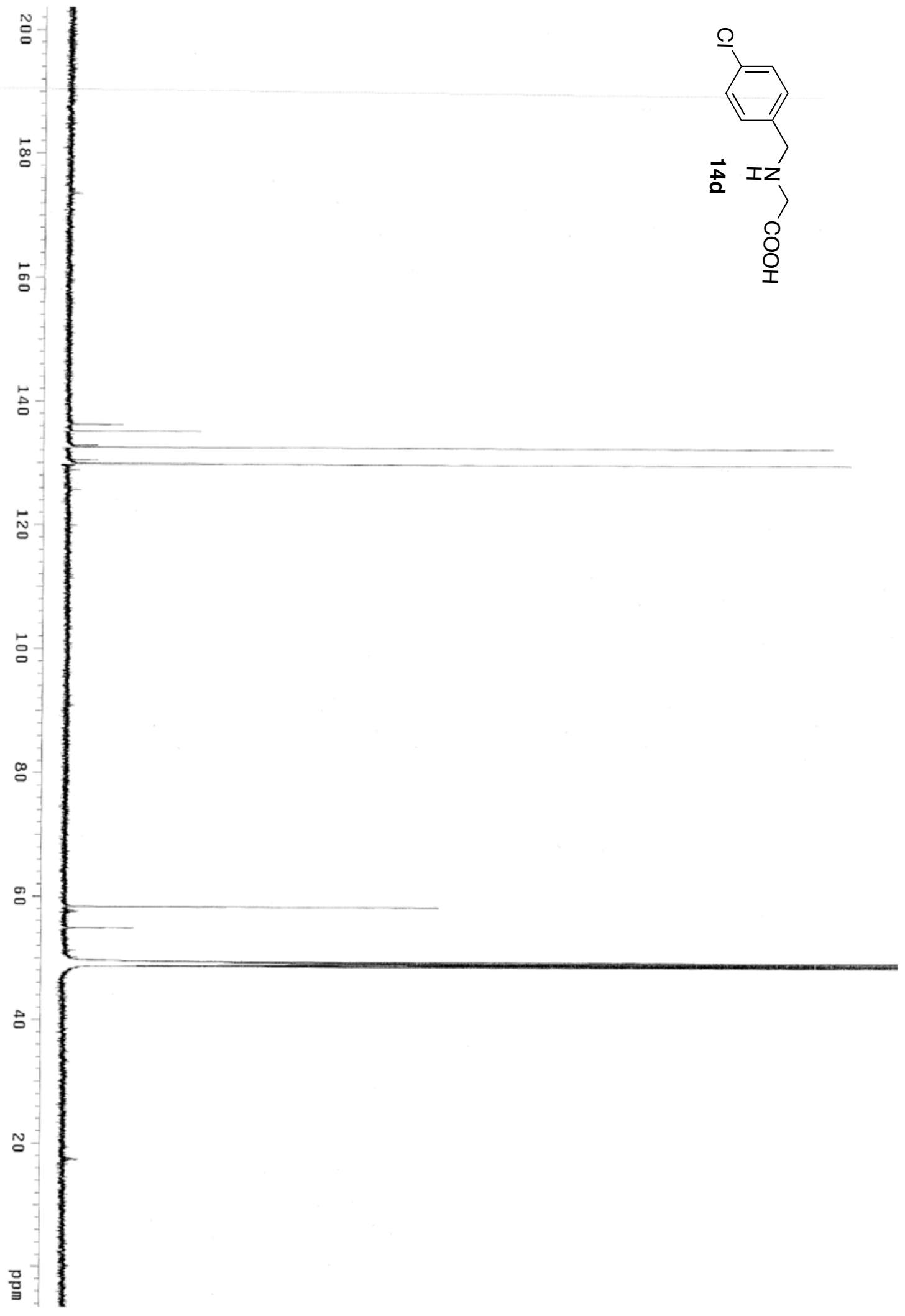

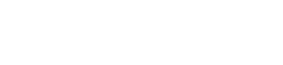

Hagen 